\title{
Modeliranje postotka vremena provedenog u koloni na dvotračnim izvangradskim cestama
}

\section{Čutura, Boris}

Doctoral thesis / Disertacija

2018

Degree Grantor / Ustanova koja je dodijelila akademski / stručni stupanj:

University of Split, Faculty of Civil Engineering, Architecture and Geodesy / Sveučilište u Splitu, Fakultet građevinarstva, arhitekture i geodezije

https://doi.org/10.31534/DocT.045.CutB

Permanent link / Trajna poveznica: https://urn.nsk.hr/urn:nbn:hr:123:260191

Rights / Prava: In copyright/Zaštićeno autorskim pravom.

Download date / Datum preuzimanja: 2023-04-26

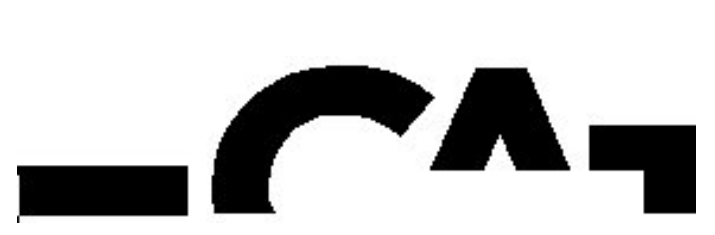

Repository / Repozitorij:

FCEAG Repository - Repository of the Faculty of Civil Engineering, Architecture and Geodesy, University of Split

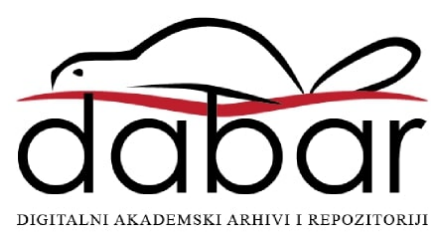




\title{
$-\mathrm{CA}_{\mathbf{1}}$ \\ SVEUČILIŠTE U SPLITU
}

\section{FAKULTET GRAĐEVINARSTVA, ARHITEKTURE I GEODEZIJE}

Boris Čutura, dipl. ing. građ.

\section{MODELIRANJE POSTOTKA VREMENA PROVEDENOG U KOLONI NA DVOTRAČNIM IZVANGRADSKIM CESTAMA}

\author{
D i s e r t a c i j a
}

Split, 2018. 
Boris Čutura, dipl. ing. građ.

Redni broj:

Ova disertacija predana je na ocjenu

Sveučilištu u Splitu,

Fakultetu građevinarstva, arhitekture i geodezije

u svrhu stjecanja akademskog stupnja

doktora tehničkih znanosti u

znanstvenom polju građevinarstva

Mentor: prof. dr. sc. Dražen Cvitanić

Komentor: izv. prof. dr. sc. Ivan Lovrić

Povjerenstvo za ocjenu:

prof. dr. sc. Dražen Cvitanić

izv. prof. dr. sc. Ivan Lovrić

izv. prof. dr. sc. Deana Breški 


\section{Povjerenstvo za obranu:}

prof. dr. sc. Dražen Cvitanić

izv. prof. dr. sc. Ivan Lovrić

izv. prof. dr. sc. Deana Breški

Rad je obranjen dana 22. svibnja 2018. godine

Tajnica:

Saša Delić, dipl. iur. 
Rad sadrži:

121 stranica teksta

49 slika

53 grafikona

48 tablica

52 citirane reference 
Posebnu zahvalnost dugujem mentoru prof. dr. sc. Draženu Cvitaniću, komentoru izv. prof. dr. sc. Ivanu Lovriću te izv. prof. dr. sc. Deani Breški na pomoći, posvećenom vremenu i trudu pri izradi doktorskog rada.

Također hvala obitelji, prijateljima i kolegama na pomoći i podršci.

Zahvala također i njemačkoj tvrtci PTV iz Karlsruhea koja mi je omogućila korištenje Vissima 9 za izradu doktorskog rada. 
Boris Čutura, dipl. ing. građ.

\section{Modeliranje postotka vremena provedenog u koloni na dvotračnim izvangradskim cestama}

\section{Sažetak:}

Dvotračne izvangradske ceste u Bosni i Hercegovini $(\mathrm{BiH})$ čine najveći postotak cestovne mreže i preuzimaju gotovo kompletan promet. Zbog toga se često stvaraju kolone i brzine vozila se smanjuju. Za poboljšanje kvalitete odvijanja prometa potrebno je utvrditi razinu usluge RU za postojeće stanje te za alternativne mogućnosti rekonstrukcije kritičnih elemenata cestovne mreže.

RU se prema Highway Capacity Manual 2010 (HCM 2010) za dvotračne ceste definira preko mjera efikasnosti: prosječna brzina putovanja (ATS) za ceste I klase i postotak vremena provedenog u koloni (PTSF) za I i II klasu cesta. HCM pretpostavlja prevelike vrijednosti ATS-a za uvjete na magistralnim (u Hrvatskoj državnim) cestama koje odgovaraju klasi I u HCM klasifikaciji, a problem je i neujednačenost geometrije elemenata cesta, što dodatno otežava primjenu ATS-a u BiH. Stoga se u ovom radu istraživao PTSF kao primjerena mjera za određivanje efikasnosti izvangradskih dvotračnih cesta. Istraživanja provedena u svijetu pokazuju značajne razlike u rezultatima PTSF-a u odnosu na proračune prema HCM-u. U regiji nisu provedena nikakva istraživanja ove problematike i HCM se koristi u izvornom obliku.

Navedeni razlozi su bili glavni motiv za istraživanje ove teme i izradu modela koji će biti jednostavno primjenjiv i u praksi. Istraživanje je provedeno za magistralne ceste s računskom brzinom $80 \mathrm{~km} / \mathrm{h}$, iz razloga što su one najvažnije u dvotračnoj cestovnoj mreži.

U ovoj disertaciji je na osnovu provedenih terenskih istraživanja najprije urađena kalibracija i validacija simulacijskog softwarea Vissim 9. Razlog primjene simulacijskog softwarea je taj što on omogućuje simuliranje različitih prometnih uvjeta koji se pojavljuju na terenu ali ih je nemoguće sve obuhvatiti snimanjem ili pak za provjeru nekih novih prometnih uvjeta.

$\mathrm{Na}$ temelju provedenih simulacija različitih prometnih uvjeta dobiven je novi model za proračun PTSF-a dvotračnih izvangradskih cesta (za brzinu $80 \mathrm{~km} / \mathrm{h}$ ). Dobiveni model proračuna PTSF-a validiran je na drugoj dionici i dobiveni rezultati su pokazali primjenjivost modela.

Ključne riječi: postotak vremena provedenog u koloni, dvotračne ceste, vrijeme slijeda, model 
Boris Čutura, M. Sc. C. E.

\title{
Estimating percent time spent following on two-lane rural highways
}

\begin{abstract}
:
In Bosnia and Herzegovina $(\mathrm{B} \& \mathrm{H})$, two-lane rural highways make up the largest percentage of road network and accommodate almost complete traffic. Because of this, platoons are often formed and vehicle speeds are reduced. To improve the quality of traffic flow, it is necessary to define the level of service (LOS) for the existing condition and for alternative possibilities of reconstructing critical elements of the road network.

According to Highway Capacity Manual 2010 (HCM 2010), for two-lane highways LOS is defined by measures of efficiency: average travel speed (ATS) for road class I and percent time spent following (PTSF) for road classes I and II. HCM assumes very high ATS values for conditions on national roads that are classified as class I according to HCM classification, and the problem is also nonuniformity of highway geometry elements, which further complicates the application of ATS in B\&H. Therefore, PTSF was studied in this paper as an appropriate measure for determining the efficiency of two-lane rural highways. Researches carried out in the world show significant differences in PTSF results compared to the HCM calculations. No research on this topic has been conducted in the region and HCM is used in its original form.

The above reasons were the main motive to study this topic and develop a model that would be easy to apply in practice. The survey was conducted on main roads with calculation speed of $80 \mathrm{~km} / \mathrm{h}$, because they are the most important in the two-lane road network.

In this dissertation, calibration and validation of the Vissim 9 simulation software was first made based on conducted field research. The reason for application of the simulation software is that it allows simulation of different traffic conditions that occur in the field but cannot all be covered by surveying, or for testing some new traffic conditions.

Based on the simulations of different traffic conditions, a new model for calculation of PTSF on two-lane rural roads (for speed $80 \mathrm{~km} / \mathrm{h}$ ) was obtained. The obtained PTSF calculation model was validated on another section and the obtained results proved the applicability of the model.
\end{abstract}

Keywords: percent time spent following, two-lane highways, headway, model 


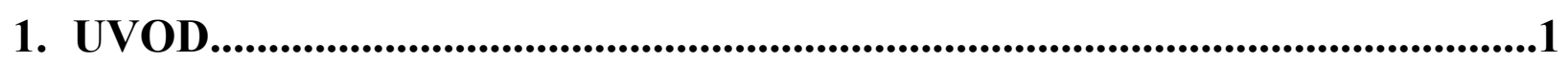

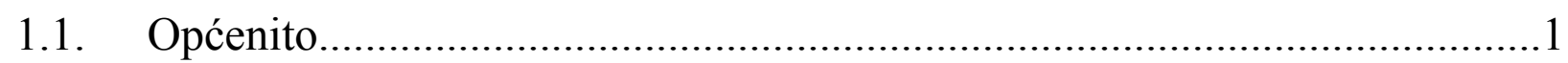

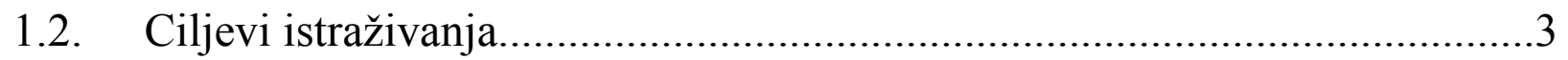

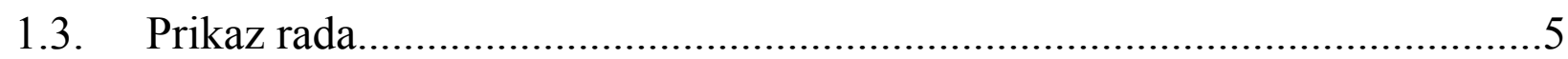

2. PREGLED POSTOJEĆIH MODELA I DOSADAŠNJIH

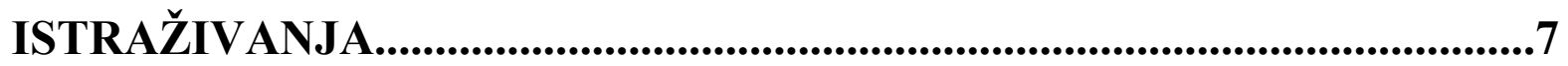

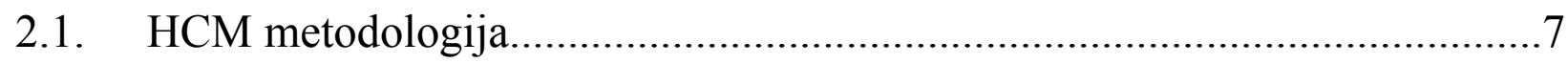

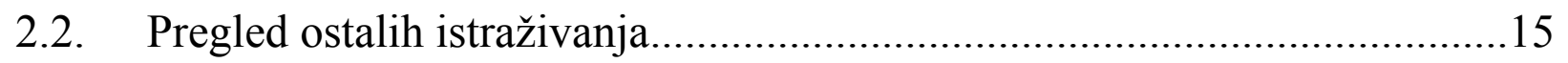

3. METODOLOGIJA TERENSKIH ISTRAŽIVANJA DVOTRAČNIH

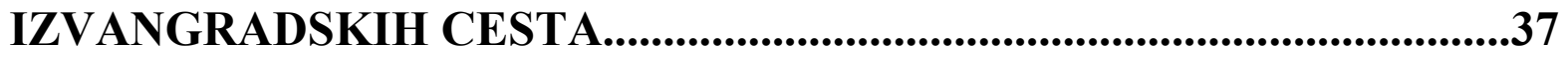

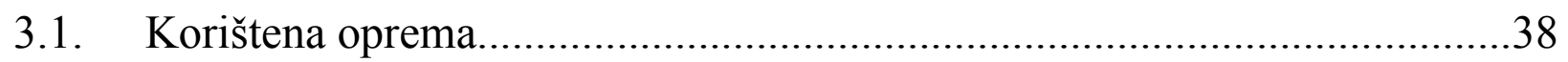

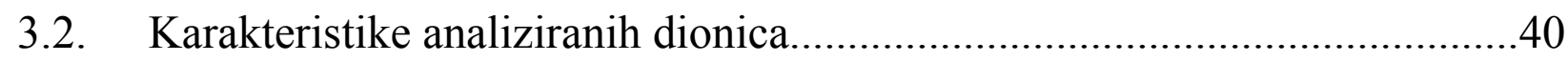

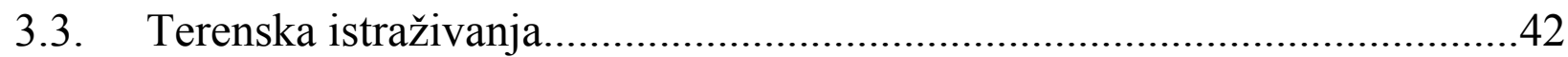

4. ANALIZA REZULTATA ISTRAŽIVANJA_........................................53

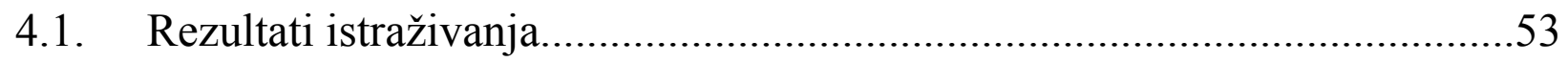

4.1.1. Smjer Salakovac - Grabovica (Mostar - Sarajevo)..............................................54

4.1.2. Smjer Grabovica - Salakovac (Sarajevo - Mostar)................................................58

4.1.3. Snimanje zona za pretjecanje duljina $450 \mathrm{~m}$......................................................62

4.2. Usporedba dobivenih rezultata s HCM metodologijom..............................65

4.3. Nedostaci primjene HCM metodologije.....................................................67

4.3.1. Proračun PTSF-a preko BPTSF-a......................................................................67

4.3.2. Distribucija brzina i udio teških vozila...................................................................67

4.3.3. Utjecaj suprotnog toka na PTSF analiziranog toka............................................67 
4.3.4. Utjecaj No-Passing zona na PTSF.

4.3.5. Duljina i broj pojedinih zona pretjecanja......................................................69

4.4. Usporedba rezultata istraživanja s drugim modelima.............................70

5. SIMULACIJSKI SOFTWARE VISSIM 9 I KALIBRACIJA

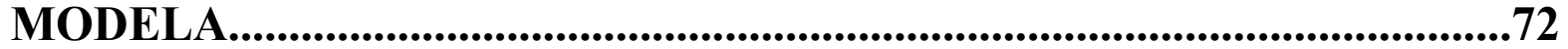

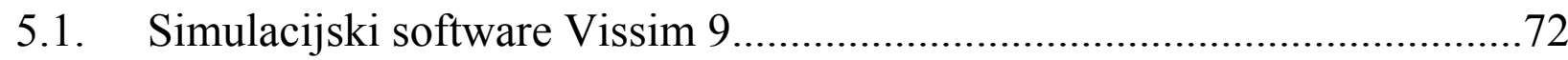

5.1.1. Model slijeda vozila (Car Following model)...................................................... 72

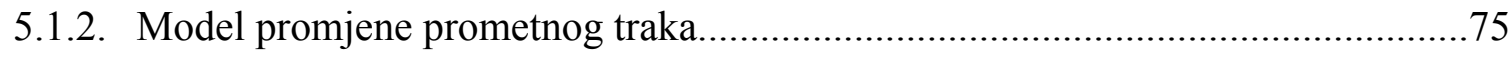

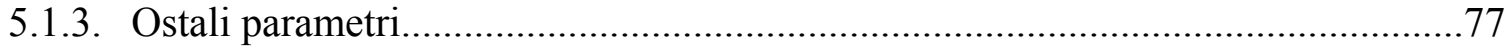

5.2. Kalibracija modela.................................................................... 78

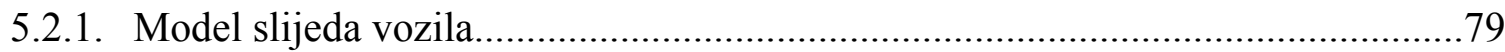

5.2.2. Model promjene prometnog traka................................................................. 79

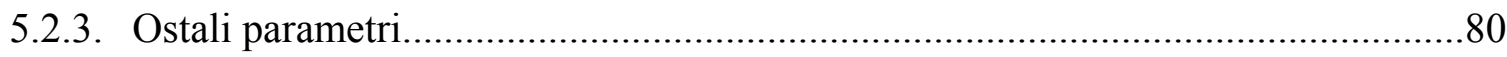

5.3. Rezultati kalibracije i validacije modela............................................82

6. MODELIRANJE POSTOTKA VREMENA PROVEDENOG U KOLONI..................................................................................................................85

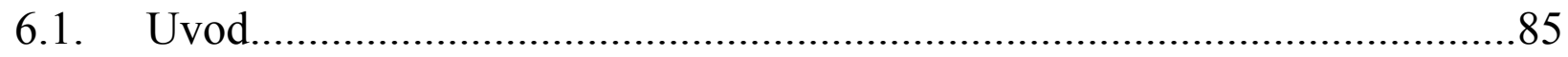

6.2. Definiranje nakupljanja i maksimalnih vrijednosti PTSF-a......................86

6.3. Definiranje utjecaja zona pretjecanja na PTSF dionice.........................91

6.4. Novi model proračuna PTSF-a......................................................... 109

6.5. Validacija modela....................................................................... 110

7. ZAKLJUČCI I SMJERNICE ZA BUDUĆI RAD......................................114

7.1. Zaključci................................................................................ 114

7.2. Preporuke za daljnja istraživanja..................................................115

8. LITERATURA.........................................................................116 


\section{UVOD}

\subsection{Općenito}

Dvotračne izvangradske ceste čine preko 90 \% mreže cesta u Bosni i Hercegovini, kao i u velikom broju drugih država. Prometna opterećenja (PGDP) su u rasponu od nekoliko desetaka do preko 12000 vozila na dan, a računske brzine od 40 do $80 \mathrm{~km} / \mathrm{h}$.

S obzirom na nerazvijenost ostale prometne infrastrukture (autoceste, brze ceste, željeznice), kompletan teretni promet odvija se ovom mrežom, što dodatno usložnjava situaciju na mreži.

Zbog svega navedenog, brzine vozila su dosta male $u$ odnosu na preporučene za pojedine kategorije cesta prema pravilniku o cestama [P.1]. Mogućnosti pretjecanja su ograničene što izaziva zagušenja prometa. U takvim uvjetima, osobito pri većem prometnom opterećenju, stvaraju se kolone vozila, brzine vozila se smanjuju i gustoća prometa raste. To uzrokuje i nedopuštene prometne radnje kao što su pretjecanje i obilaženje vozila na nedopuštenim mjestima, što dovodi do prometnih nesreća s težim posljedicama.

Da bi se odabrao način poboljšanja mreže (veće pretjecajne duljine, dodatni trak, itd.) potrebno je ponajprije analizirati postojeće stanje odvijanja prometa.

Kvaliteta odvijanja prometa definira se preko razine usluge (RU) i kreće se od razine " $\mathrm{A}$ " za „idealne uvjete“ do razine usluge " $\mathrm{F}^{\text {“ }}$ koja predstavlja potpuno zagušenje (tok premašuje kapacitet). RU na dvotračnim izvangradskim dionicama, prema u svijetu najraširenijoj američkoj metodologiji Highway Capacity Manual HCM [T.1, T.2, T.3], definira se temeljem dviju mjera efikasnosti: prosječna brzina putovanja ATS (average travel speed) i postotak vremena provedenog u koloni PTSF (precent time spent following).

Parametar PTSF definiran je kao postotak vremena koje vozilo provede u koloni na nekoj dionici vozeći se iza sporijeg vozila. Ovaj parametar definira slobodu manevriranja i udobnost vožnje. Povezan je i sa sigurnosti prometa jer vožnja u koloni izaziva nervozu kod vozača i rizične reakcije kao što je npr. pretjecanje u opasnim situacijama. Kao takav, postotak vremena provedenog u koloni je najvažnija mjera u smislu opisa kvalitete odvijanja prometa.

PTSF je prvi put, prema ovakvoj definiciji, uveden u četvrtom izdanju Highway Capacity Manual-a iz 2000. godine (HCM 2000) [T.1], a zadržan je i u izdanjima HCM 2010 [T.2] te šestom izdanju iz 2016. godine [T.3]. Prethodno je u HCM 1985 [T.4] uvedena mjera postotak zakašnjenja PD (percent delay) koja je bila na tragu kasnije definicije i mjerenja PTSF-a. Prema HCM-u ceste se dijele na 3 klase. 
Ceste klase I definirane su kao daljinske i vezne ceste (međugradske, međuregionalne) gdje vozači očekuju velike brzine i vožnju bez ometanja. Za njih se razina usluge definira preko ATS-a i PTSF-a.

U klasu II cesta spadaju ceste uglavnom kraćih duljina (obično su to ceste koje povezuju ceste klase I) gdje vozači ne očekuju velike brzine. RU ovih cesta računa se samo preko PTSF-a.

HCM 2010 [T.2] je uveo i klasu III cesta u koju spadaju ceste umjereno razvijenih (izgrađenih) područja ili ceste kroz mala naselja. Osobine ovih cesta su ograničene brzine i miješanje lokalnog s tranzitnim prometom. RU se računa preko postotka od brzine slobodnog toka PFFS (percent of free-flow speed).

HCM pretpostavlja prevelike vrijednosti brzina slobodnog toka $(70-110 \mathrm{~km} / \mathrm{h}) \mathrm{za} \mathrm{BiH}$ uvjete, a time posljedično i velike vrijednosti ATS-a što ne odgovara brzinama vožnje na dvotračnim izvangradskim cestama u $\mathrm{BiH}$.

Dodatni problem primjene HCM-a u ovdašnjim uvjetima je i velika neujednačenost geometrije (time i brzina) elemenata ceste te je vrlo teško definirati prosječnu brzinu putovanja pojedinih dionica, što onemogućuje komparaciju ATS-a. Stoga, ATS kao kriterij nije prikladan za određivanje RU dvotračnih izvangradskih cesta u BiH pa je disertacija fokusirana na PTSF-u kao mjeri efikasnosti.

Veliki problem predstavlja način definiranja PTSF-a na terenu. HCM je definirao vrijeme slijeda (headway) od 3 sekunde između vozila kao mjeru za određivanje PTSF-a. Ako je vrijeme slijeda manje od 3 sekunde vozila su u koloni, a u suprotnom se voze „slobodno“ (slike 1.1 i 1.2).

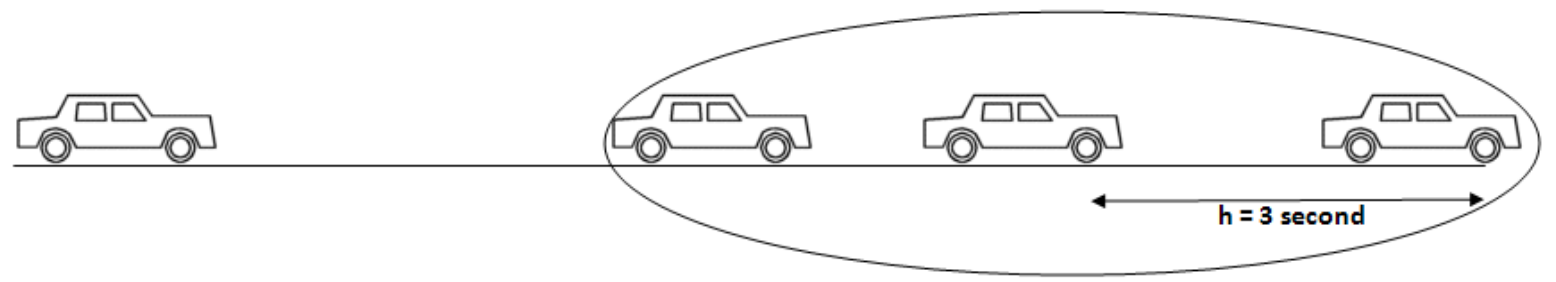

Slika 1.1. Vozila u koloni prema HCM-u

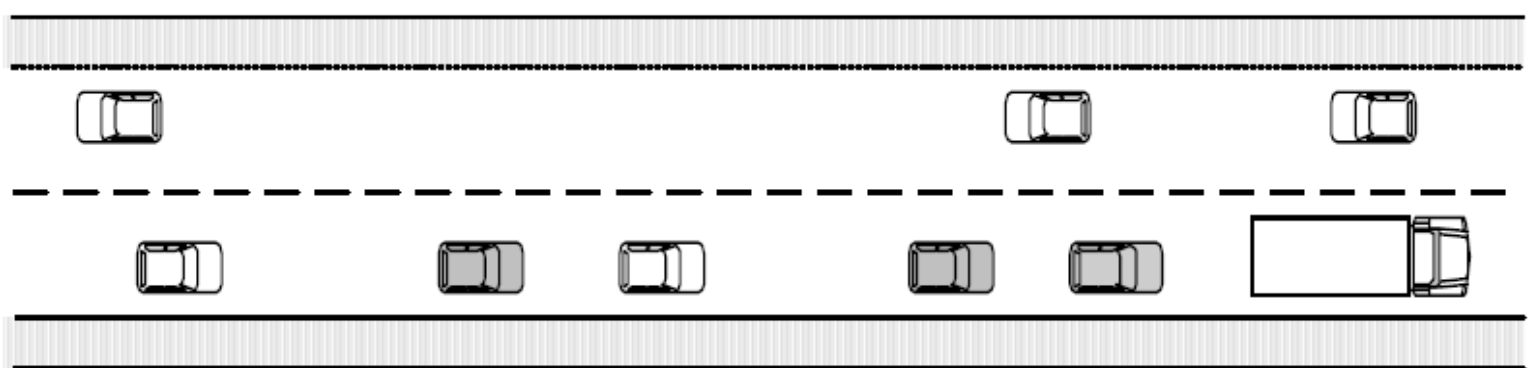

Slika 1.2. Prikaz vozila u koloni 
Terenska istraživanja provedena za potrebe ove disertacije pokazuju značajna odstupanja u odnosu na proračune prema HCM metodologiji, a rezultat su drugačijih uvjeta odvijanja prometnih tokova kao i nedostataka samog modela. Tu neprilagođenost prevladavajućim prometnim uvjetima pokazala su i mnoga druga istraživanja [L.1, L.2, D.1, H.1, V.1] provedena tijekom zadnjih 15-ak godina. Također, niti drugi modeli razvijeni u svijetu (veliki broj u posljednjih dvadesetak godina) nisu prikladni za korištenje u $\mathrm{BiH}$ uvjetima. Razlog toga je također neprilagođenost lokalnim uvjetima, kao i drugačiji pristupi [A.1. A.2, A.3, A.4, B.1, B.2, L.3, P.2, P.3, P.4, R.1, R.2, R.3, S.1, V.1] koji su teško primjenjivi na ceste u BiH. Jedan dio pristupa fokusiran je na brzine koje nisu prikladan parametar za $\mathrm{BiH}$ uvjete. Drugi dio pristupa odnosi se na drugačije definiranje kolona u smislu percepcije vozača kako on doživljava kolone, jer ne doživljavaju svi vozači kao vožnju u koloni jednaku granicu vremena slijeda. Stoga se za konstantno vrijeme slijeda uvodi i vjerojatnost da je vozilo dio kolone. Ovakvi novi pristupi bi, osobito s obzirom na nepostojanje istraživanja, zahtijevali izradu potpuno nove i za $\mathrm{BiH}$ isuviše kompleksne metodologije proračuna PTSF-a.

U regiji posljednjih desetljeća nisu provedena nikakva istraživanja ove problematike i HCM se u praksi koristi u izvornom obliku.

Navedeni razlozi su bili glavni motiv za istraživanje ove teme i izradu modela procjene veličine PTSF-a koji će biti jednostavno primjenjiv i u praksi. Istraživanje je provedeno za magistralne ceste s računskom brzinom $80 \mathrm{~km} / \mathrm{h}$, iz razloga što su one najvažnije u dvotračnoj cestovnoj mreži.

U ovoj disertaciji je na osnovu provedenih terenskih istraživanja PTSF-a najprije urađena kalibracija i validacija simulacijskog softwarea Vissim 9. Razlog primjene simulacijskog softwarea je taj što on omogućuje simuliranje različitih prometnih uvjeta (različite kombinacije prometnih opterećenja) koji se pojavljuju na terenu ali ih je nemoguće sve obuhvatiti snimanjem ili pak za provjeru nekih novih prometnih uvjeta kao što je npr. primjena različitih zona za pretjecanje.

$\mathrm{Na}$ temelju provedenih simulacija različitih prometnih uvjeta urađen je model za proračun PTSF-a dvotračnih izvangradskih cesta. Na kraju je dobiveni model proračuna PTSF-a validiran na dionici s koje podaci o PTSF-u nisu korišteni za izradu modela i dobiveni rezultati su pokazali primjenjivost modela.

\subsection{Ciljevi istraživanja}

U uvodu su spomenuti problemi određivanja RU za dvotračne izvangradske ceste i nedostatak istraživanja ove problematike u regiji. 
Cilj istraživanja je analizirati postojeće stanje odvijanja prometnog toka u uvjetima kakvi prevladavaju na magistralnoj cestovnoj mreži u Bosni i Hercegovini, a zatim na temelju dosadašnjih istraživanja o metodama proračuna i dobivenim novim spoznajama, definirati novi model za proračun PTSF-a. Novi model proračuna PTSF-a temelji se na drugačijem pristupu definiranja početnih (baznih uvjeta) te, za prevladavajuće lokalne uvjete, boljim definiranjem postojećih i uvođenjem novih parametara za proračun PTSF-a.

Ciljevi rada su:

- Definiranje početnih (baznih) uvjeta koji bi bili prilagođeni prevladavajućim lokalnim uvjetima u BiH. HCM proračun PTSF-a temelji na baznim uvjetima koji predstavljaju idealne uvjete (100\% pretjecanja na dionici) koji se zatim korigiraju na prevladavajuće uvjete korekcijskim faktorom utjecaja postotka zona bez pretjecanja. Na cestovnoj mreži u BiH najveći broj dionica ima postotak zona za pretjecanje od 15 do $30 \%$ (ostatak dionica najvećim dijelom čak i manji postotak) te je stoga za proračun PTSF-a logičniji pristup za početne uvjete uzeti nemogućnost pretjecanja na cijeloj dionici (0\% zona pretjecanja) koji se zatim korigira utjecajem zona za pretjecanje.

- Utvrđivanje utjecajnih faktora prometnog toka dvotračnih cesta na PTSF koji do sada nisu bili dovoljno istraženi. To se ponajprije odnosi na utjecaj duljine dionice te broj i duljine zona za pretjecanje na analiziranoj dionici. Dosadašnje metodologije nisu uzimale u obzir duljinu analizirane dionice iako ima utjecaja, osobito na dionicama s malom mogućnošću pretjecanja gdje PTSF kontinuirano raste. Također, u proračunu PTSF-a koristi se korekcijski faktor pretjecanja preko ukupnog postotka zona za pretjecanje na cijeloj dionici, a koji ne definira utjecaje duljina pojedinih zona za pretjecanje.

- Izrada novog modela za određivanje postotka vremena provedenog u koloni (time i razine usluge dvotračnih izvangradskih cesta) koji ovisi o duljini dionice te broju i duljinama pojedinih zona pretjecanja.

Metodologija istraživanja uključuje:

- Terenska istraživanja na dvotračnim izvangradskim cestama koja obuhvaćaju sve relevante faktore za analizu prometnog toka kao što su veličina prometnog toka, struktura toka, geometrija, brzine, vrijeme slijeda, itd. Sljedeći korak je analiza PTSF-ova dobivenih na terenu i njihova usporedba (uz kritički osvrt) s HCM-om i drugim metodologijama.

- Prometne simulacije u simulacijskom softveru Vissim 9.0 (Planung Transport Verkehr PTV, Karlsruhe). Nakon terenskih istraživanja slijedi kalibracija i validacija softvera te simulacije različitih slučajeva prometnih uvjeta $\mathrm{u}$ smislu prometnih opterećenja 
(kombinacije prometnih opterećenja po smjerovima) i mogućnosti pretjecanja (različite duljine i položaj zona za pretjecanje).

- Izrada modela za određivanje postotka vremena provedenog u koloni PTSF-a i njegova validacija na terenu te komparacija dobivenog modela $s$ najkorištenijim postojećim modelima u svijetu.

\subsection{Prikaz rada}

Rad se sastoji od sedam poglavlja i literature te je u nastavku dat kratak opis pojedinih poglavlja.

Uvodno poglavlje iznosi osnovne postavke o temi istraživanja, a zatim ciljeve rada $\mathrm{s}$ metodologijom istraživanja.

Pregled postojećih modela i dosadašnjih istraživanja je drugo poglavlje koje prikazuje kronološki pregled dosadašnjih istraživanja na ovu temu, s kritičkim osvrtom na njih. U pregledu su obuhvaćena i ona istraživanja koja nisu direktno vezana za problem PTSF-a, ali su zanimljiva zbog drugačijeg pristupa definiranja razine usluge dvotračnih izvangradskih cesta.

Terenska istraživanja dvotračnih izvangradskih cesta prikazuju provedena istraživanja na dvotračnim državnim (magistralnim) izvangradskim cestama u Hercegovini. Prikazane su karakteristike istraživane dionice i metodologija samog istraživanja. Prikupljeni su podaci o veličini prometnog toka, strukturi toka, geometriji ceste, brzinama, vremenu slijeda, itd. $\mathrm{Na}$ temelju vremena slijeda dobivene su vrijednosti PTSF-a u ovisnosti o prometnom opterećenju.

Analiza rezultata istraživanja je četvrto poglavlje i u njemu se analiziraju i kvantificiraju faktori prometnog toka (prometna opterećenja analiziranog i suprotnog toka, brzine, vrijeme slijeda) neophodni za simulacije prometa i izradu modela proračuna PTSF-a. Prikazani su rezultati PTSF-a dobiveni na terenu, koji su zatim uspoređeni $\mathrm{s}$ HCM-om i drugim metodologijama uz kritički osvrt na njih.

Simulacijski software Vissim 9 i kalibracija modela peto je poglavlje u kojem je prikazan Vissim 9, njegovi podmodel i najvažniji parametari podmodela. Kalibrirani su najvažniji (najosjetljiviji) parametri na jednosm setu podataka, a zatim su validirani na drugom setu podataka. Najvažniji parametri su željena brzina (zadana preko distribucije) i željeno vrijeme slijeda između vozila. Kalibracija i validacija Vissima 9 dobivena je na način da su uspoređivane vrijednosti PTSF-a u mjernim presjecima na terenu (7 presjeka) s presjecima zadanim u Vissimu (zadani presjeci u Vissimu odgovaraju položaju na terenu). Dobivene razlike u vrijednostima PTSF-a unutar su granice od $5 \%$. 
Modeliranje postotka vremena provedenog u koloni je šesto poglavlje i u njemu se provode simulacije različitih slučajeva geometrije ceste (različite duljine i položaji zona za pretjecanje) i kombinacija prometnih opterećenja (kombinacija opterećenja po smjerovima). Prikazane su postavke novog pristupa u smislu drugačijeg definiranja početnih (baznih) uvjeta preko prosječne vrijednosti $P T S F_{100 \% N P Z}$ (kad nema pretjecanja na dionici) te zakonitosti njegove promjene (rasta po duljini u funkciji o prometnom opterećenju). Kvantificiran je utjecaj pojedinih duljina zona za pretjecanje na PTSF dionice te je izražen preko koeficijenata utjecaja $\mathrm{k}_{\mathrm{p}}$.

Kao rezultat istraživanja izrađen je model za određivanje postotka vremena provedenog $\mathrm{u}$ koloni PTSF-a koji se temelji na korekciji prosječne vrijednosti $P T S F \overline{100 \% N P Z}$, za utjecaje pojedinih zona za pretjecanje. Na kraju je provedena validacija modela na drugom setu podataka izmjerenih na terenu (na drugoj dionici ceste) i dobiveni su rezultati koji potvrđuju ispravnost primjene modela.

Zaključci i smjernice za budući rad iznose najvažnije zaključke rada vezano za novi model proračuna PTSF-a i njegovu jednostavnu primjenu u praksi. Na kraju su dane smjernice daljnih istraživanja koje omogućuju poboljšanje modela za širu primjenu, kao i mogući načini poboljšanja razine usluge (dodatni trak za pretjecanje).

Literatura daje popis svih članaka i dokumenata koji su korišteni u radu. 


\section{PREGLED POSTOJEĆIH MODELA I DOSADAŠNJIH ISTRAŽIVANJA}

U ovom poglavlju se opisuje HCM metodologija, a nakon toga je dan i pregled ostalih istraživanja u svijetu. Osim pregleda istraživanja koji se tiču izravno PTSF-a, prikazana su i neka zanimljiva istraživanja gdje se koristio drugačiji pristup i uvodile nove mjere efikasnosti za definiranje razine usluge.

\subsection{HCM metodologija}

\section{Razvoj PTSF-a kroz HCM metodologiju}

Highway Capacity Manual (HCM) je najpoznatija i u svijetu najraširenija metodologija za proračune kapaciteta i razine usluge. Primjenjuje se u velikom broju država u izvornom obliku, pa tako i u našoj regiji, jer nisu provedena istraživanja i prilagodbe lokalnim uvjetima.

Prvo izdanje HCM-a je izašlo 1950. godine i nije sadržavalo definiciju razine usluge.

U drugom izdanju iz 1965. godine definira se razina usluge, a kao mjere efikasnosti (MOE) za dvotračne ceste koristile su se operativne brzine te odnos opterećenja i kapaciteta (v/c).

Treće izdanje iz 1985. godine kao mjere efikasnosti definira prosječnu brzinu putovanja (ATS) i postotak vremena zakašnjenja (percent time delay, PD).

Četvrto izdanje iz 2000. zadržava ATS te uvodi postotak vremena provedenog u koloni (percent time-spent following PTSF) kao mjeru efikasnosti prometa.

Posljednja izdanja HCM-a (HCM 2010 i šesto izdanje iz 2016. godine) pored ATS-a i PTSF-a uvode još i treću mjeru efikasnosti postotak od brzine slobodnog toka (percent of free flow speed PFFS) koja se odnosi na uvedenu treću klasu cesta. Kako je tema rada PTSF, u nastavku će biti opisana izdanja i poglavlja vezana za ovu temu.

HCM 1985 (TRB 1985) [T.4] u svom trećem izdanju uvodi postotak vremena zakašnjenja PD (percent time delay). PD je definiran kao postotak od ukupnog vremena koje vozač provede u koloni iza sporijeg vozila. Odnos PD-a i ukupnog prometnog opterećenja za oba smjera prikazan je grafikonom na slici 2.1 [T.4]. Kao mjera za dobivanje parametra PD na terenu definirano je vrijeme slijeda manje od $5 \mathrm{~s}$.

Razine usluge su definirane na temelju ukupnog postotka, dok su granične vrijednosti prikazane u tablici 2.1 . 


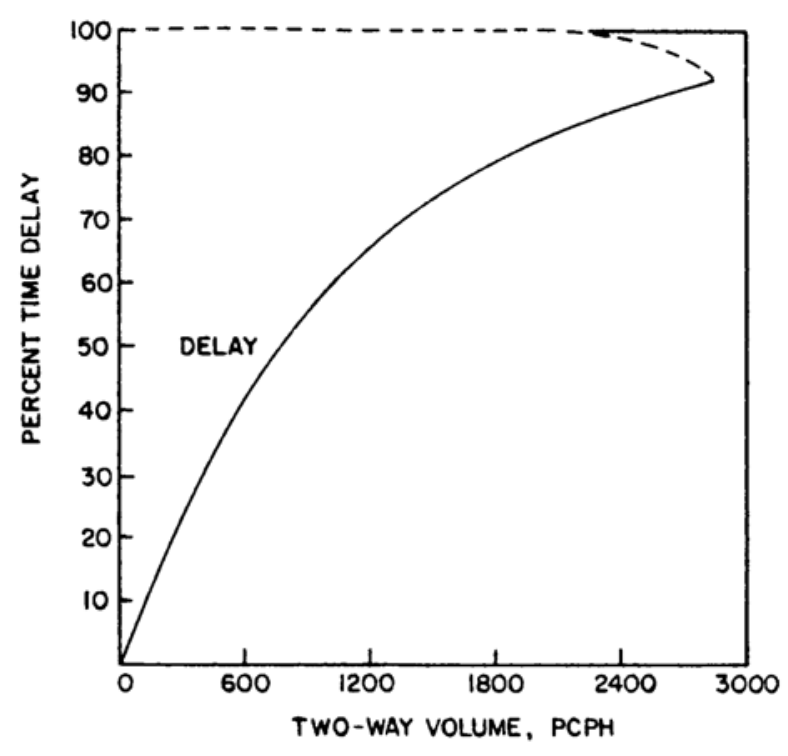

Slika 2.1. Odnos PD-a i ukupnog dvosmjernog volumena prema HCM 1985 [T.4]

Tablica 2.1. Razina usluge na osnovu vrijednosti PD-a [T.4]

\begin{tabular}{|c|c|}
\hline LOS A & $\leq 30 \%$ time delay \\
\hline LOS B & $\leq 45 \%$ time delay \\
\hline LOS C & $\leq 60 \%$ time delay \\
\hline LOS D & $\leq 75 \%$ time delay \\
\hline LOS E & $\leq 100 \%$ time delay \\
\hline LOS F & $100 \%$ time delay \\
\hline
\end{tabular}

Vrijednost vremena slijeda od $5 \mathrm{~s}$ bila je predmet rasprava i neki autori su predlagali manje vrijednosti [L.3].

HCM 2000 (TRB 2000) [T.1] je prvi uveo PTSF kao mjeru kvalitete toka. Razine usluge su računate prema jednosmjernim (directional) i dvosmjernim (two-way) analizama. Prvo se odredi PTSF za idealne (bazne) uvjete (definiran je kao BPTSF), a zatim se korigira za prevladavajuće uvjete. Idealni (bazni) uvjeti prema HCM-u podrazumijevaju širine voznih trakova minimalno $3.6 \mathrm{~m}(12 \mathrm{ft})$, bočne smetnje na udaljenosti minimalno $1.8 \mathrm{~m}(6 \mathrm{ft})$, mogućnost pretjecanja na $100 \%$ dionice, prometa samo osobnih vozila, ravan teren (cesta bez nagiba) i bez ometanja u smislu semafora, priključaka, itd.

U dvosmjernoj analizi uvrsti se ukupno prometno opterećenje oba smjera, a zatim se utjecaj raspodjele prometa po smjeru i utjecaj zona bez pretjecanja korigira preko koeficijenta $f_{d / n p}$. U jednosmjernoj analizi uvrštava se prometno opterećenje analiziranog smjera, a utjecaj 
suprotnog smjera (preko prometnog opterećenja) definira se preko određenih koeficijenata. Zatim se koeficijentom $f_{n p} u$ jednosmjernoj analizi definira utjecaj zona bez pretjecanja. $U$ dvosmjernoj se analiziraju istovremeno oba smjera i uvrštava se ukupno prometno opterećenje, a zatim se koeficijentom $f_{d / n p}$ definira kombinirani utjecaj raspodjele prometnog opterećenja po smjerovima i postotka zona bez pretjecanja.

Dvosmjerna analiza daje manje vrijednosti od jednosmjerne, a mogu se dobiti i nelogični rezultati za ekstremne slučajeve distribucije po smjeru (PTSF veći od $100 \%$ za npr. 200 voz/h u anliziranom smjeru i $1700 \mathrm{voz} / \mathrm{h}$ u suprotnom). Zbog ovih razloga, u sljedećim izdanjima HCMa zadržana je samo jednosmjerna analiza.

Ceste su podijeljene na klasu I za koju se razina usluge definirala preko ATS-a i PTSF-a, te klasu II gdje se RU računa samo preko PTSF-a. Vrijednosti ovih mjera efikasnosti za određivanje razine usluge prikazane su u tablici 2.2 .

Tablica 2.2. Vrijednosti ATS I PTSF za određivanje razine usluge [T.1]

\begin{tabular}{|c|cc|c|}
\hline \multirow{2}{*}{ LOS } & \multicolumn{2}{|c|}{ Class I Highways } & $\begin{array}{c}\text { Class II } \\
\text { Highways }\end{array}$ \\
& ATS (mi/h) & PTSF (\%) & PTSF (\%) \\
\hline A & $>55$ & $\leq 35$ & $\leq 40$ \\
B & $>50-55$ & $>35-50$ & $>40-55$ \\
C & $>45-50$ & $>50-65$ & $>55-70$ \\
D & $>40-45$ & $>65-80$ & $>70-85$ \\
E & $\leq 40$ & $>80$ & $>85$ \\
\hline
\end{tabular}

Prometno opterećenje se svodi na ekvivalentno opterećenje osobnih vozila (passanger-car equivalent PCE). Vrijednosti faktora ekvivalencije za teška vozila (HV) i rekreacijska vozila (RVs) dana su u tablici 2.3.

Tablica 2.3. Faktor ekvivalencije za teška i rekreacijska vozila [T.1]

\begin{tabular}{|c|c|c|c|c|}
\hline \multirow{2}{*}{ Vehicle Type } & \multirow{2}{*}{$\begin{array}{c}\text { Range of Two-Way } \\
\text { Flow Rates (pc/h) }\end{array}$} & \multirow{2}{*}{$\begin{array}{c}\text { Range of Directional } \\
\text { Flow Rates (pc/h) }\end{array}$} & \multicolumn{2}{|c|}{ Type of Terrain } \\
\hline & & & Level & Rolling \\
\hline Trucks, $\mathrm{E}_{\mathrm{T}}$ & $\begin{array}{c}0-600 \\
>600-1200 \\
>1200\end{array}$ & $\begin{array}{c}0-300 \\
>300-600 \\
>600\end{array}$ & $\begin{array}{l}1.1 \\
1.1 \\
1.0\end{array}$ & $\begin{array}{l}1.8 \\
1.5 \\
1.0\end{array}$ \\
\hline$R V s, E_{R}$ & $\begin{array}{c}0-600 \\
>600-1200 \\
>1200\end{array}$ & $\begin{array}{c}0-300 \\
>300-600 \\
>600\end{array}$ & $\begin{array}{l}1.0 \\
1.0 \\
1.0\end{array}$ & $\begin{array}{l}1.0 \\
1.0 \\
1.0\end{array}$ \\
\hline
\end{tabular}


Kako su kasnije metodologije (HCM 2010) zadržale samo jednosmjernu (iz ranije navedenih razloga) i ovaj rad se temelji na jednosmjernoj analizi.

PTSF za jednosmjernu (directional) analizu se dobije iz izraza:

$$
P T S F_{d}=\text { BPTSF }_{d}+f_{n p}
$$

Gdje su:

- $P T S F_{d}=$ postotak vremena provedenog u koloni u analiziranom smjeru

- $B P T S F_{d}=$ bazni postotak vremena provedenog u koloni u analiziranom smjeru koji predstavlja mogućnost pretjecanja od $100 \%$ na dionici

- $f_{n p,}=$ korekcijski faktor koji opisuje utjecaj postotka zona bez pretjecanja (no-passing zones) na PTSF za analizirani smjer

Korekcijski faktor za postotak zona bez pretjecanja $\mathrm{f}_{\mathrm{np}}$, za raspon opterećenja od 100 do $>1600 \mathrm{voz} / \mathrm{h}$, prikazan je u tablici 2.4 .

Tablica 2.4. Koeficijent $\mathrm{f}_{\mathrm{np}}$ za proračun PTSF-a jednosmjerne analize prema HCM 2000 [T.1]

\begin{tabular}{|c|c|c|c|c|c|}
\hline \multirow{2}{*}{$\begin{array}{l}\text { Opposing demands } \\
\text { Flow Rate, } v_{o}(\mathrm{pc} / \mathrm{h})\end{array}$} & \multicolumn{5}{|c|}{ Percent No-Passing Zones } \\
\hline & 20 & 40 & 60 & 80 & 100 \\
\hline \multicolumn{6}{|c|}{$\mathrm{FFS}=65 \mathrm{mi} / \mathrm{h}$} \\
\hline$\leq 100$ & 10.1 & 17.2 & 20.2 & 21.0 & 21.8 \\
\hline 200 & 12.4 & 19.0 & 22.7 & 23.8 & 24.8 \\
\hline 400 & 9.0 & 12.3 & 14.1 & 14.4 & 15.4 \\
\hline 600 & 5.3 & 7.7 & 9.2 & 9.7 & 10.4 \\
\hline 800 & 3.0 & 4.6 & 5.7 & 6.2 & 6.7 \\
\hline 1000 & 1.8 & 2.9 & 3.7 & 4.1 & 4.4 \\
\hline 1200 & 1.3 & 2.0 & 2.6 & 2.9 & 3.1 \\
\hline 1400 & 0.9 & 1.4 & 1.7 & 1.9 & 2.1 \\
\hline$\geq 1600$ & 0.7 & 0.9 & 1.1 & 1.2 & 1.4 \\
\hline \multicolumn{6}{|c|}{$\mathrm{FFS}=60 \mathrm{mi} / \mathrm{h}$} \\
\hline$\leq 100$ & 8.4 & 14.9 & 20.9 & 22.8 & 26.6 \\
\hline 200 & 11.5 & 18.2 & 24.1 & 26.2 & 29.7 \\
\hline 400 & 8.6 & 12.1 & 14.8 & 15.9 & 18.1 \\
\hline 600 & 5.1 & 7.5 & 9.6 & 10.6 & 12.1 \\
\hline 800 & 2.8 & 4.5 & 5.9 & 6.7 & 7.7 \\
\hline 1000 & 1.6 & 2.8 & 3.7 & 4.3 & 4.9 \\
\hline 1200 & 1.2 & 1.9 & 2.6 & 3.0 & 3.4 \\
\hline 1400 & 0.8 & 1.3 & 1.7 & 2.0 & 2.3 \\
\hline$\geq 1600$ & 0.6 & 0.9 & 1.1 & 1.2 & 1.5 \\
\hline \multicolumn{6}{|c|}{$\mathrm{FFS}=55 \mathrm{mi} / \mathrm{h}$} \\
\hline$\leq 100$ & 6.7 & 12.7 & 21.7 & 24.5 & 31.3 \\
\hline 200 & 10.5 & 17.5 & 25.4 & 28.6 & 34.7 \\
\hline 400 & 8.3 & 11.8 & 15.5 & 17.5 & 20.7 \\
\hline 600 & 4.9 & 7.3 & 10.0 & 11.5 & 13.9 \\
\hline 800 & 2.7 & 4.3 & 6.1 & 7.2 & 8.8 \\
\hline
\end{tabular}




\begin{tabular}{|c|c|c|c|c|c|}
\hline 1000 & 1.5 & 2.7 & 3.8 & 4.5 & 5.4 \\
\hline 1200 & 1.0 & 1.8 & 2.6 & 3.1 & 3.8 \\
\hline 1400 & 0.7 & 1.2 & 1.7 & 2.0 & 2.4 \\
\hline$\geq 1600$ & 0.6 & 0.9 & 1.2 & 1.3 & 1.5 \\
\hline \multicolumn{6}{|c|}{$\mathrm{FFS}=50 \mathrm{mi} / \mathrm{h}$} \\
\hline$\leq 100$ & 5.0 & 10.4 & 22.4 & 26.3 & 36.1 \\
\hline 200 & 9.6 & 16.7 & 26.8 & 31.0 & 39.6 \\
\hline 400 & 4.9 & 11.6 & 16.2 & 19.0 & 23.4 \\
\hline 600 & 4.7 & 7.1 & 10.4 & 12.4 & 15.6 \\
\hline 800 & 2.5 & 4.2 & 6.3 & 7.7 & 9.8 \\
\hline 1000 & 1.3 & 2.6 & 3.8 & 4.7 & 5.9 \\
\hline 1200 & 0.9 & 1.7 & 2.6 & 3.2 & 4.1 \\
\hline 1400 & 0.6 & 1.1 & 1.7 & 2.1 & 2.6 \\
\hline$\geq 1600$ & 0.5 & 0.9 & 1.2 & 1.3 & 1.6 \\
\hline \multicolumn{6}{|c|}{$\mathrm{FFS}=45 \mathrm{mi} / \mathrm{h}$} \\
\hline$\leq 100$ & 3.7 & 8.5 & 23.2 & 28.2 & 41.6 \\
\hline 200 & 8.7 & 16.0 & 28.2 & 33.6 & 45.2 \\
\hline 400 & 7.5 & 11.4 & 16.9 & 20.7 & 26.4 \\
\hline 600 & 4.5 & 6.9 & 10.8 & 13.4 & 17.6 \\
\hline 800 & 2.3 & 4.1 & 6.5 & 8.2 & 11.0 \\
\hline 1000 & 1.2 & 2.5 & 3.8 & 4.9 & 6.4 \\
\hline 1200 & 0.8 & 1.6 & 2.6 & 3.3 & 4.5 \\
\hline 1400 & 0.5 & 1.0 & 1.7 & 2.2 & 2.8 \\
\hline$\geq 1600$ & 0.4 & 0.9 & 1.2 & 1.3 & 1.7 \\
\hline
\end{tabular}

Bazni postotak vremena provedenog u koloni se dobije iz sljedećeg izraza:

$$
\text { BPTSF }_{d}=100\left[1-\exp \left(a v_{d}{ }^{b}\right)\right]
$$

Gdje je:

- $v_{d}=$ prometni tok analiziranog smjera (ov/h)

Koeficijenti a i b za proračun PTSF-a za jednosmjerni segment se dobiju iz tablice 2.5, gdje $\mathrm{v}_{\mathrm{o}}$ predstavlja prometni tok suprotnog smjera (ov/h).

Tablica 2.5. Koeficijenti a i b za proračun PTSF-a za jednosmjerni segment [T.1]

\begin{tabular}{|c|c|c|}
\hline $\begin{array}{c}\text { Opposing Demand } \\
\text { Flow Rate, } \boldsymbol{v}_{\boldsymbol{o}} \text { (pc/h) }\end{array}$ & $\boldsymbol{a}$ & $\boldsymbol{b}$ \\
\hline$\leq 200$ & -0.013 & 0.668 \\
400 & -0.057 & 0.479 \\
600 & -0.100 & 0.413 \\
800 & -0.173 & 0.349 \\
1,000 & -0.320 & 0.276 \\
1,200 & -0.430 & 0.242 \\
1,400 & -0.522 & 0.225 \\
$\geq 1,600$ & -0.665 & 0.199 \\
\hline
\end{tabular}


HCM 2010 (TRB, 2010) [T.2] zadržava PTSF kao mjeru efikasnosti na dvotračnim cestama, ali uvodi i treću klasu cesta na koju se odnosi parametar postotak od brzine slobodnog toka PFFS (percent of free flow speed). Ostavljena je samo jednosmjerna (directional) analiza.

PTSF je doživio neke promjene u odnosu na prethodni model HCM $2000 \mathrm{u}$ smislu vrijednosti utjecajnih koeficijenata, a to se odrazilo i na manje vrijednosti PTSF-a u proračunu. Granične vrijednosti mjera efikasnosti za određivanje razine usluge klasa I i II su ostale nepromijenjene (tablica 2.6.).

Tablica 2.6. Vrijednosti ATS, PTSF i PFFS za određivanje razine usluge [T.2]

\begin{tabular}{|c|cc|c|c|}
\hline & \multicolumn{2}{|c|}{ Class I Highways } & $\begin{array}{c}\text { Class II } \\
\text { Highways }\end{array}$ & $\begin{array}{c}\text { Class III } \\
\text { Highways }\end{array}$ \\
\hline LOS & ATS (mi/h) & PTSF (\%) & $\frac{\text { PTSF (\%) }}{\text { PFFS (\%) }}$ \\
\hline A & $>55$ & $\leq 35$ & $\leq 40$ & $>91.7$ \\
B & $>50-55$ & $>35-50$ & $>40-55$ & $>83.3-91.7$ \\
C & $>45-50$ & $>50-65$ & $>55-70$ & $>75.0-83.3$ \\
D & $>40-45$ & $>65-80$ & $>70-85$ & $>66.7-75.0$ \\
E & $\leq 40$ & $>80$ & $>85$ & $\leq 66.7$ \\
\hline
\end{tabular}

Vrijednosti faktora ekvivalencije za teretna vozila (HV) i rekreacijska (RVs) data su u tablici 2.7.

Tablica 2.7. Faktor ekvivalencije za teška i rekreacijska vozila [T.2]

\begin{tabular}{|c|c|c|c|}
\hline $\begin{array}{c}\text { Vehicle } \\
\text { Type }\end{array}$ & $\begin{array}{c}\text { Directional } \\
\text { Demand Flow } \\
\text { Rate, } \boldsymbol{v}_{\boldsymbol{v} \boldsymbol{h}}(\mathbf{v e h} / \mathbf{h})\end{array}$ & $\begin{array}{c}\text { Level and } \\
\text { Specific } \\
\text { Downgrade }\end{array}$ & Rolling \\
\hline \multirow{5}{*}{ Trucks, $E_{T}$} & $\leq 100$ & 1.1 & 1.9 \\
& 200 & 1.1 & 1.8 \\
& 300 & 1.1 & 1.7 \\
& 400 & 1.1 & 1.6 \\
& 500 & 1.0 & 1.4 \\
& 600 & 1.0 & 1.2 \\
& 700 & 1.0 & 1.0 \\
& 800 & 1.0 & 1.0 \\
\hline RVs, $E_{R}$ & $\geq 900$ & 1.0 & 1.0 \\
\hline
\end{tabular}

PTSF se računa na osnovu sljedećeg izraza:

$$
\mathrm{PTSF}_{\mathrm{d}}=\mathrm{BPTSF}_{\mathrm{d}}+\mathrm{f}_{\mathrm{np}, \mathrm{PTSF}}\left(\frac{\mathrm{v}_{\mathrm{d}, \mathrm{PTSF}}}{\mathrm{v}_{\mathrm{d}, \mathrm{PTSF}}+\mathrm{v}_{\mathrm{o}, \mathrm{PTSF}}}\right)
$$


Gdje su:

- $P T S F_{d}=$ postotak vremena provedenog u koloni u analiziranom smjeru

- $B P T S F_{d}=$ bazni postotak vremena provedenog u koloni u analiziranom smjeru

- $f_{n p, P T S F}=$ korekcijski faktor za postotak zona bez pretjecanja (no-passing zones) za analizirani smjer

- $v_{d, P T S F}=$ prometni tok analiziranog smjera $(\mathrm{ov} / \mathrm{h})$

- $\quad v_{o, P T S F}=$ prometni tok suprotnog smjera $(\mathrm{ov} / \mathrm{h})$

Koeficijenti a i b za proračun BPTSF-a za jednosmjerni segment dobiju se na temelju tablice 2.8 [T.2].

Tablica 2.8. Koeficijenti a i b za proračun BPTSF-a za jednosmjerni segment [T.2]

\begin{tabular}{|c|c|c|}
\hline $\begin{array}{c}\text { Opposing Demand } \\
\text { Flow Rate, } \boldsymbol{v}_{\boldsymbol{o}} \mathbf{( p c / h )}\end{array}$ & Coefficient $\boldsymbol{a}$ & Coefficient $\boldsymbol{b}$ \\
\hline$\leq 200$ & -0.0014 & 0.973 \\
400 & -0.0022 & 0.923 \\
600 & -0.0033 & 0.870 \\
800 & -0.0045 & 0.833 \\
1,000 & -0.0049 & 0.829 \\
1,200 & -0.0054 & 0.825 \\
1,400 & -0.0058 & 0.821 \\
$\geq 1,600$ & -0.0062 & 0.817 \\
\hline
\end{tabular}

Tablica 2.9. Korekcijski faktor $f_{n p}$ za proračun PTSF-a za jednosmjerni segment [T.2]

\begin{tabular}{|c|cccccc|}
\hline $\begin{array}{c}\text { Total Two-Way Flow } \\
\text { Rate, } \boldsymbol{v}=\boldsymbol{v}_{\boldsymbol{d}}+\boldsymbol{v}_{\boldsymbol{o}}(\mathbf{p c} / \mathbf{h})\end{array}$ & $\mathbf{0}$ & $\mathbf{2 0}$ & $\mathbf{4 0}$ & $\mathbf{6 0}$ & $\mathbf{8 0}$ & $\mathbf{1 0 0}$ \\
\hline \multicolumn{7}{|c|}{ Directional Split $=50 / 50$} \\
\hline$\leq 200$ & 9.0 & 29.2 & 43.4 & 49.4 & 51.0 & 52.6 \\
400 & 16.2 & 41.0 & 54.2 & 61.6 & 63.8 & 65.8 \\
600 & 15.8 & 38.2 & 47.8 & 53.2 & 55.2 & 56.8 \\
800 & 15.8 & 33.8 & 40.4 & 44.0 & 44.8 & 46.6 \\
1400 & 12.8 & 20.0 & 23.8 & 26.2 & 27.4 & 28.6 \\
2000 & 10.0 & 13.6 & 15.8 & 17.4 & 18.2 & 18.8 \\
2600 & 5.5 & 7.7 & 8.7 & 9.5 & 10.1 & 10.3 \\
3200 & 3.3 & 4.7 & 5.1 & 5.5 & 5.7 & 6.1 \\
\hline \multicolumn{7}{|c|}{ Directional Split $=60 / 40$} \\
400 & 11.0 & 30.6 & 41.0 & 51.2 & 52.3 & 53.5 \\
\hline & 14.6 & 36.1 & 44.8 & 53.4 & 55.0 & 56.3 \\
\hline
\end{tabular}




\begin{tabular}{|c|c|c|c|c|c|c|}
\hline 600 & 14.8 & 36.9 & 44.0 & 51.1 & 52.8 & 54.6 \\
\hline 800 & 13.6 & 28.2 & 33.4 & 38.6 & 39.9 & 41.3 \\
\hline 1400 & 11.8 & 18.9 & 22.1 & 25.4 & 26.4 & 27.3 \\
\hline 2000 & 9.1 & 13.5 & 15.6 & 16.0 & 16.8 & 17.3 \\
\hline 2600 & 5.9 & 7.7 & 8.6 & 9.6 & 10.0 & 10.2 \\
\hline \multicolumn{7}{|c|}{ Directional Split $=70 / 30$} \\
\hline$\leq 200$ & 9.9 & 28.1 & 38.0 & 47.8 & 48.5 & 49.0 \\
\hline 400 & 10.6 & 30.3 & 38.6 & 46.7 & 47.7 & 48.8 \\
\hline 600 & 10.9 & 30.9 & 37.5 & 43.9 & 45.4 & 47.0 \\
\hline 800 & 10.3 & 23.6 & 28.4 & 33.3 & 34.5 & 35.5 \\
\hline 1400 & 8.0 & 14.6 & 17.7 & 20.8 & 21.6 & 22.3 \\
\hline 2000 & 7.3 & 9.7 & 11.7 & 13.3 & 14.0 & 14.5 \\
\hline \multicolumn{7}{|c|}{ Directional Split $=80 / 20$} \\
\hline$\leq 200$ & 8.9 & 27.1 & 37.1 & 47.0 & 47.4 & 47.9 \\
\hline 400 & 6.6 & 26.1 & 34.5 & 42.7 & 43.5 & 44.1 \\
\hline 600 & 4.0 & 24.5 & 31.3 & 38.1 & 39.1 & 40.0 \\
\hline 800 & 3.8 & 18.5 & 23.5 & 28.4 & 29.1 & 29.9 \\
\hline 1400 & 3.5 & 10.3 & 13.3 & 16.3 & 16.9 & 32.2 \\
\hline 2000 & 3.5 & 7.0 & 8.5 & 10.1 & 10.4 & 10.7 \\
\hline \multicolumn{7}{|c|}{ Directional Split $=90 / 10$} \\
\hline$\leq 200$ & 4.6 & 24.1 & 33.6 & 43.1 & 43.4 & 43.6 \\
\hline 400 & 0.0 & 20.2 & 28.3 & 36.3 & 36.7 & 37.0 \\
\hline 600 & -3.1 & 16.8 & 23.5 & 30.1 & 30.6 & 31.1 \\
\hline 800 & -2.8 & 10.5 & 15.2 & 19.9 & 20.3 & 20.8 \\
\hline 1400 & -1.2 & 5.5 & 8.3 & 11.0 & 11.5 & 11.9 \\
\hline
\end{tabular}

HCM metodologija je bila predmet kritika od samog početka zbog parametra PTSF-a. Istraživači [A.5, D.1, H.1, L.1, L.2, O.1, V.1] su uočavali znatne razlike u rezultatima dobivenim prema HCM metodologiji i rezultatima dobivenim na terenu.

Predmet kritika bio je i način mjerenja PTSF-a preko postotka onih koji slijede PF-a (percent followers) i konstantnog vremena slijeda od 3 s [A.2, A.3, H.2, P.2, P.3, R.1]. Time se ne uzima potpuno u obzir ponašanje vozača i njihova željena vremena slijeda.

Kritike na PTSF su bile da nije parametar koji egzaktno ukazuje na potrebu poboljšanja cestovne mreže [G.1] i jer se npr. za mala opterećenja mogu dobiti velike vrijednosti PTSF-a [P.5] koje ukazuju na potrebu za poboljšanjem dionice, a što realno nije potrebno.

Pojedini istraživači [A.1, A.2, C.1] su ukazali na problem vrijednosti ekvivalentnog opterećenja osobnih vozila jer se utjecaj teških vozila $\left(\mathrm{E}_{\mathrm{T}}\right)$ nije dovoljno valorizirao.

Naravno, problem primjene HCM metodologije je i neprilagođenost lokalnim uvjetima kakvi prevladavaju u pojedinim područjima za koje se primjenjuje. 
Zbog problema mjerenja PTSF-a predlagane su nove mjere efikasnosti za određivanje razine usluge. U nastavku će biti više riječi o predloženim novim mjerama efikasnosti i prijedlozima poboljšanja HCM-a.

\subsection{Pregled ostalih istraživanja}

U nastavku su prikazana dosadašnja istraživanja vezana za definiranje razine usluge dvotračnih izvangradskih cesta. Prikazani su rezultati istraživanja ponajprije PTSF-a kao mjere efikasnosti, ali također i drugi pristupi koji su pokušali na drugačiji način opisati kvalitetu prometnog toka.

Greenshields [G.2] početkom šesdesetih godina 20. stoljeća definira „faktore frustracije“ prilikom vožnje sporije od željene brzine. Uvodi index kvalitete Q (quality index) definiran kao:

$$
\mathrm{Q}=\frac{1000 \cdot \mathrm{S}}{\Delta_{\mathrm{s}} \sqrt{\mathrm{f}}}
$$

Gdje su:

- $\mathrm{S}=$ prosječna brzina $(\mathrm{km} / \mathrm{h})$

- $\Delta_{\mathrm{s}}=$ apsolutna suma promjena brzina po kilometru $(\mathrm{km} / \mathrm{h})$

- $\mathrm{f}=$ broj promjena brzine po kilometru

U istraživanju je zaključio i da se kvaliteta prometnog toka ne može mjeriti u jednom presjeku jer se na taj način ne može dobiti kvalitetan uvid u prometni tok dionice.

Luttinen (2001) [L.1, L.2] je proveo istraživanja na cestama u Finskoj, a dobiveni rezultati su pokazivali značajne razlike u odnosu na HCM 2000. Izmjerene vrijednosti PTSF-a na terenu bile su znatno manje nego prema HCM-u. Kritički se osvrnuo na nelogičnosti utjecaja distribucije toka po smjerovima na rezultate modela kao npr. mogućnost da se za ekstremne slučajeve razdiobe opterećenja (npr. za analizirani smjer 200, a suprotni $1700 \mathrm{voz} / \mathrm{h}$ ) dobiju nemoguće vrijednosti PTSF-a od $130 \%$, te je predložio model koji rješava ovaj problem. Istraživanja su također pokazala da postoje razlike u PTSF-u za različita ograničenja brzine (od 80 i $100 \mathrm{~km} / \mathrm{h}$ ).

Prema ranijim istraživanjima provedenim u Finskoj, krenulo se od osnovne postavke da se u slučajnom toku vremena slijeda ravnaju prema negativnoj eksponencijalnoj razdiobi i to za jednosmjernu analizu: 


$$
\mathrm{F}\left(3 / \mathrm{q}_{\mathrm{d}}\right)=1-\mathrm{e}^{-3 \mathrm{q}_{\mathrm{d}} / 3600}=1-\mathrm{e}^{-\mathrm{q}_{\mathrm{d}} / 1200}
$$

Izraz za raspodjelu vremena slijeda za dvosmjerni tok je:

$$
F(3 / q)=1-e^{-q_{d} / 2400}
$$

Razvijen je eksponencijalni model proračuna PTSF-a za brzine 80 i $100 \mathrm{~km} / \mathrm{h}$. Ulazni podaci za analizu su bili:

1. ograničenje brzine $\left(\mathrm{v}_{1}\right)$

2. prometni tok $\mathrm{u}$ analiziranom $\left(\mathrm{q}_{\mathrm{d}}\right)$ i suprotnom smjeru $\left(\mathrm{q}_{\mathrm{o}}\right)$

3. postotak zona bez pretjecanja, s kriterijem $300 \mathrm{~m}$ pretjecajne duljine

4. širina bankine $\left(\mathrm{w}_{\mathrm{s}}\right)$

5. udio teških vozila $\left(\mathrm{P}_{\mathrm{hv}}\right)$

6. tip terena

Nakon analiza utjecaja, za proračun PTSF-a $\left(\mathrm{P}_{\mathrm{W}}\right)$ za brzinu od $80 \mathrm{~km} / \mathrm{h}$ dobio se izraz:

$$
\mathrm{P}_{\mathrm{W}}=1-\exp \left\{\left[-0.00144-0.00042 \mathrm{P}_{\mathrm{np}}+0.00009 \mu_{\mathrm{L}}(80)\right] \mathrm{q}_{\mathrm{d}}-\left(0.00732-0.00155 \mathrm{w}_{\mathrm{s}}\right) \sqrt{\mathrm{q}_{\mathrm{o}}}\right\}
$$

Gdje su:

- $\quad q_{d}=$ prometni tok $u$ analiziranom smjeru

- $\quad \mathrm{q}_{\mathrm{o}}=$ prometni tok $\mathrm{u}$ suprotnom smjeru

- $\quad \mathrm{P}_{\mathrm{np}}=$ udio zona bez pretjecanja

- $\quad \mathrm{w}_{\mathrm{s}}=$ širina bankine

- $\quad \mu_{L}=$ koeficijent vezan za brzinu, za $80 \mathrm{~km} / \mathrm{h}$ je 1 dok je za $100 \mathrm{~km} / \mathrm{h}$ vrijednost 0

Utjecaj teških vozila $f_{W, h v}$ na PTSF je dan samo za brzinu $100 \mathrm{~km} / \mathrm{h}$ i ovisi o udjelu teških vozila $\mathrm{P}_{\mathrm{hv}}$, prometnom toku promatranog $\left(\mathrm{q}_{\mathrm{d}}\right)$ i suprotnog toka $\left(\mathrm{q}_{\mathrm{o}}\right)$. Za brzinu $80 \mathrm{~km} / \mathrm{h}$ nema ovog utjecaja.

$$
f_{W, h v}=-0.000719 P_{h v} \sqrt{q_{d} q_{o}}
$$

Proračun za $100 \mathrm{~km} / \mathrm{h}$ je sveden na izraz:

$$
P_{W}=100 \cdot\left(1-\exp \left(-0.000527 q_{d}-0.003203 \sqrt{q_{o}}\right)\right)
$$

Ukupni PTSF za oba smjera je:

$$
P_{W}=\frac{q_{1} P_{w 1}+q_{2} P_{w 2}}{q_{1}+q_{2}}
$$


Prijedlog je bio da veća vrijednost PTSF-a (od dvaju analiziranih smjerova) bude mjerodavna za određivanje razine usluge (RU).

$\mathrm{Na}$ slici 2.2. prikazana je usporedba prethodno spomenutih triju finskih modela u odnosu na HCM 2000 model za različita opterećenja.

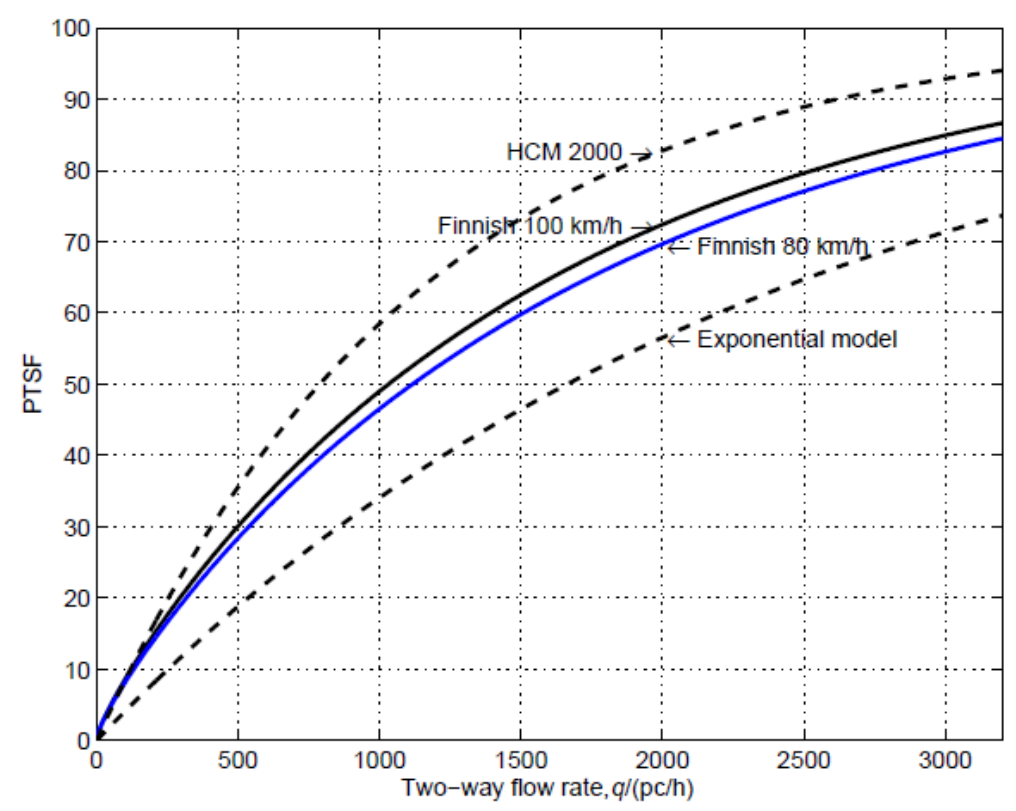

Slika 2.2. Usporedba PTSF-a finskih modela i HCM 2000 za brzine 80 i 100 km/h [L.1]

U usporedbi modela na slici može se vidjeti da model za brzinu $100 \mathrm{~km} / \mathrm{h}$ daje nešto veće vrijednosti od onog za brzinu $80 \mathrm{~km} / \mathrm{h}$ za ista opterećenja. Oba prethodna modela daju značajno veće rezultate od starog eksponencijalnog [L.3] i značajno manje od HCM 2000 modela.

Analize su pokazale i da je utjecaj teških vozila dosta mali, osobito za brzinu $80 \mathrm{~km} / \mathrm{h}$ (slika 2.3).

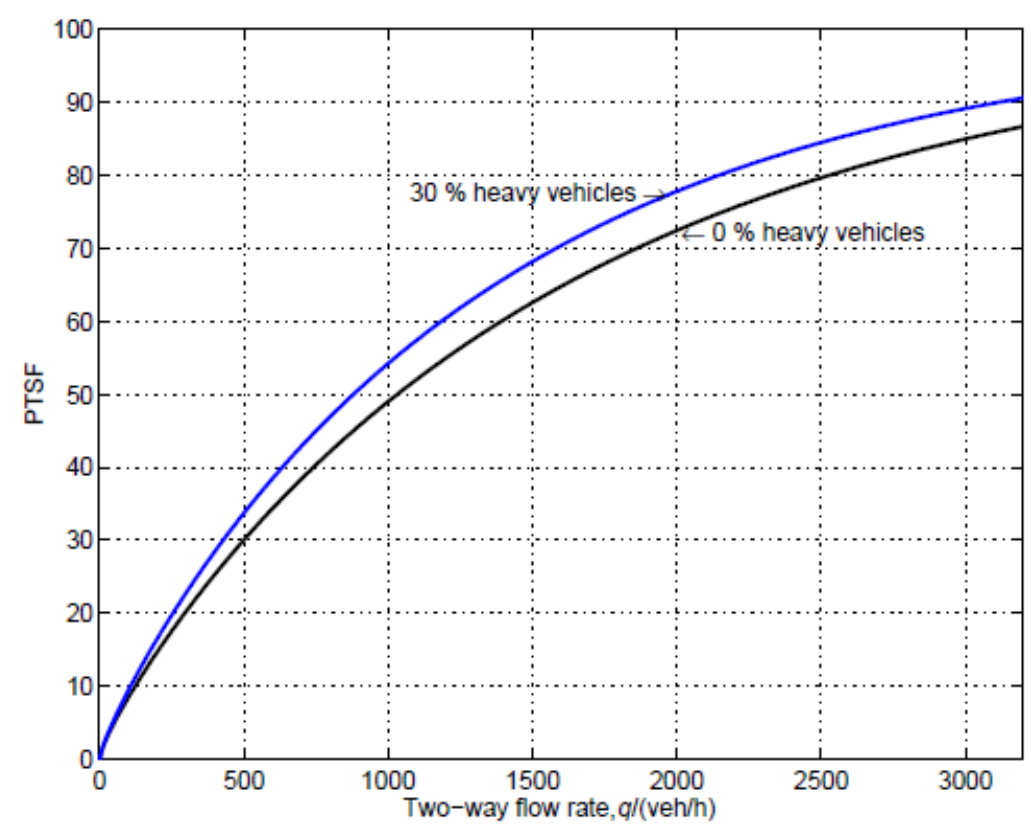

Slika 2.3. Utjecaj udjela teških vozila na PTSF [L.1] 
Date su preporuke za definiranje razine usluge s nešto izmijenjenim vrijednostima PTSF-a za brzine 80 i $100 \mathrm{~km} / \mathrm{h}$ (Tablica 2.10).

Tablica 2.10. Predloženi kriteriji za RU [L.1]

\begin{tabular}{|c|c|c|c|}
\hline $\begin{array}{c}\text { Level of } \\
\text { service }\end{array}$ & PTSF (\%) & $\begin{array}{c}\text { ATS (100 } \\
\mathrm{km} / \mathrm{h})\end{array}$ & $\begin{array}{c}\text { ATS (80 } \\
\mathrm{km} / \mathrm{h})\end{array}$ \\
\hline $\mathrm{A}$ & $\leq 35$ & $\geq 97$ & $\geq 80$ \\
\hline $\mathrm{B}$ & $\leq 50$ & $\geq 94$ & $\geq 78$ \\
\hline $\mathrm{C}$ & $\leq 65$ & $\geq 90$ & $\geq 76$ \\
\hline $\mathrm{D}$ & $\leq 80$ & $\geq 83$ & $\geq 74$ \\
\hline $\mathrm{E}$ & $>80$ & $<83$ & $<74$ \\
\hline $\mathrm{F}$ & & $<60$ & $<60$ \\
\hline
\end{tabular}

Dixon i drugi (2002) [D.1] pokušali su unaprijediti HCM 2000 proceduru u praksi i urađena su istraživanja u državi Idaho (SAD) nakon kojih su rađene simulacije u programu TWOPAS. Uveli su novi način definiranja PTSF-a preko postotka onih koji slijede PF (percent followers) koristeći kao mjeru vrijeme slijeda od 3 sekunde. Kao rezultat su dobili nekonzistentnost dvosmjerne i jednosmjerne analize i znatno veće vrijednosti PTSF-a $u$ TWOPAS-u nego na terenu preko PF-a. Dvosmjerna analiza davala je manje vrijednosti $u$ odnosu na jednosmjernu.

Harwood i drugi (2003) [H.1] analizirali su HCM 2000 uspoređujući jednosmjernu i dvosmjernu analizu. Također su dvosmjernom analizom dobili manje vrijednosti (oko 11 \%) kao i prethodni istraživači (Dixon i drugi). Zaključili su da krivulja PTSF-a raste brže za jednosmjernu analizu nego za dvosmjernu (slike 2.4 i 2.5 ).

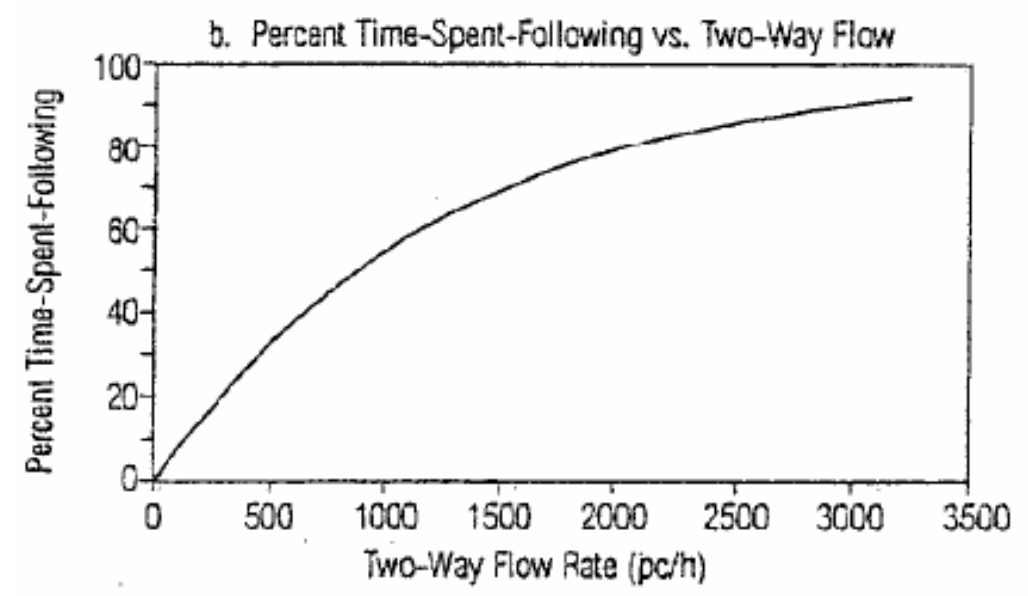

Slika 2.4. Odnos prometnog toka i PTSF-a za dvotračnu analizu za bazne uvjete [H.1] 


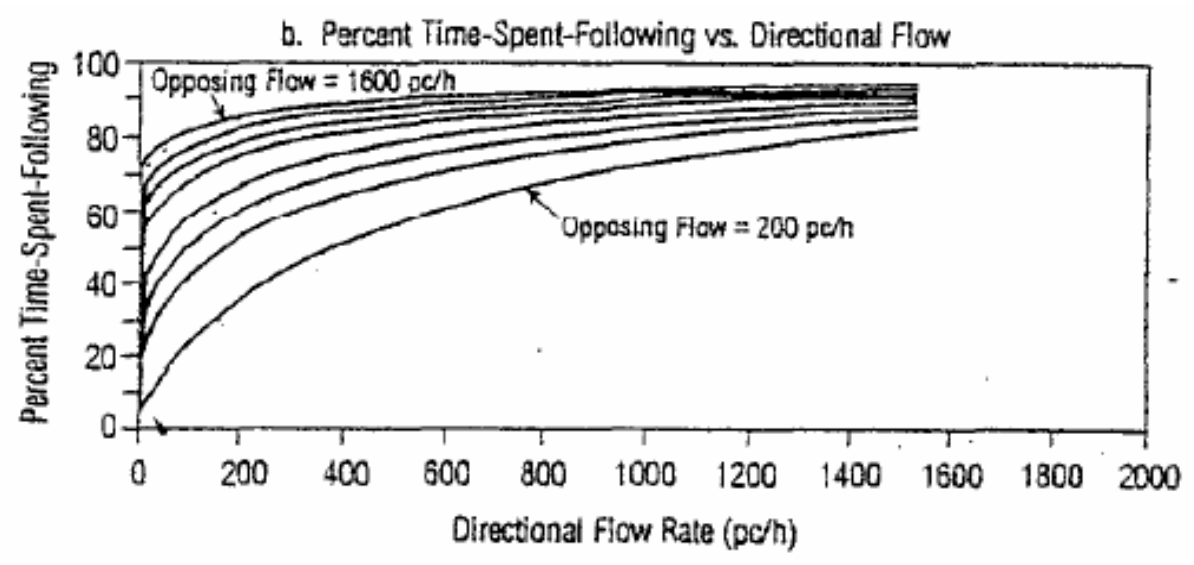

Slika 2.5. Odnos prometnog toka i PTSF-a za jednosmjernu analizu za bazne uvjete [H.1]

Drugi problem je zamijećen kod korekcijskih faktora $f_{d / n p} i f_{n p}$ te su preporučili nove vrijednosti koje su usvojene u HCM 2010 (tablica 2.8). Zaključeno je i da korekcijski faktor $f_{n p}$ treba biti izražen preko odnosa prometnog toka po smjerovima:

$$
f_{n p}=f_{a d j}\left(\frac{V_{d}}{V_{d}+V_{o}}\right)
$$

$\mathrm{U}$ prethodnom izrazu $\mathrm{V}_{\mathrm{d}}$ i $\mathrm{V}_{\mathrm{o}}$ predstavljaju ekvivalentno opterećenje osobnih vozila za analizirani i suprotni smjer, dok je $f_{\text {adj }}$ korekcijski faktor za raspodjelu po smjerovima i zonama bez pretjecanja.

Predložene izmjene prikazuje grafikon na slici 2.6.

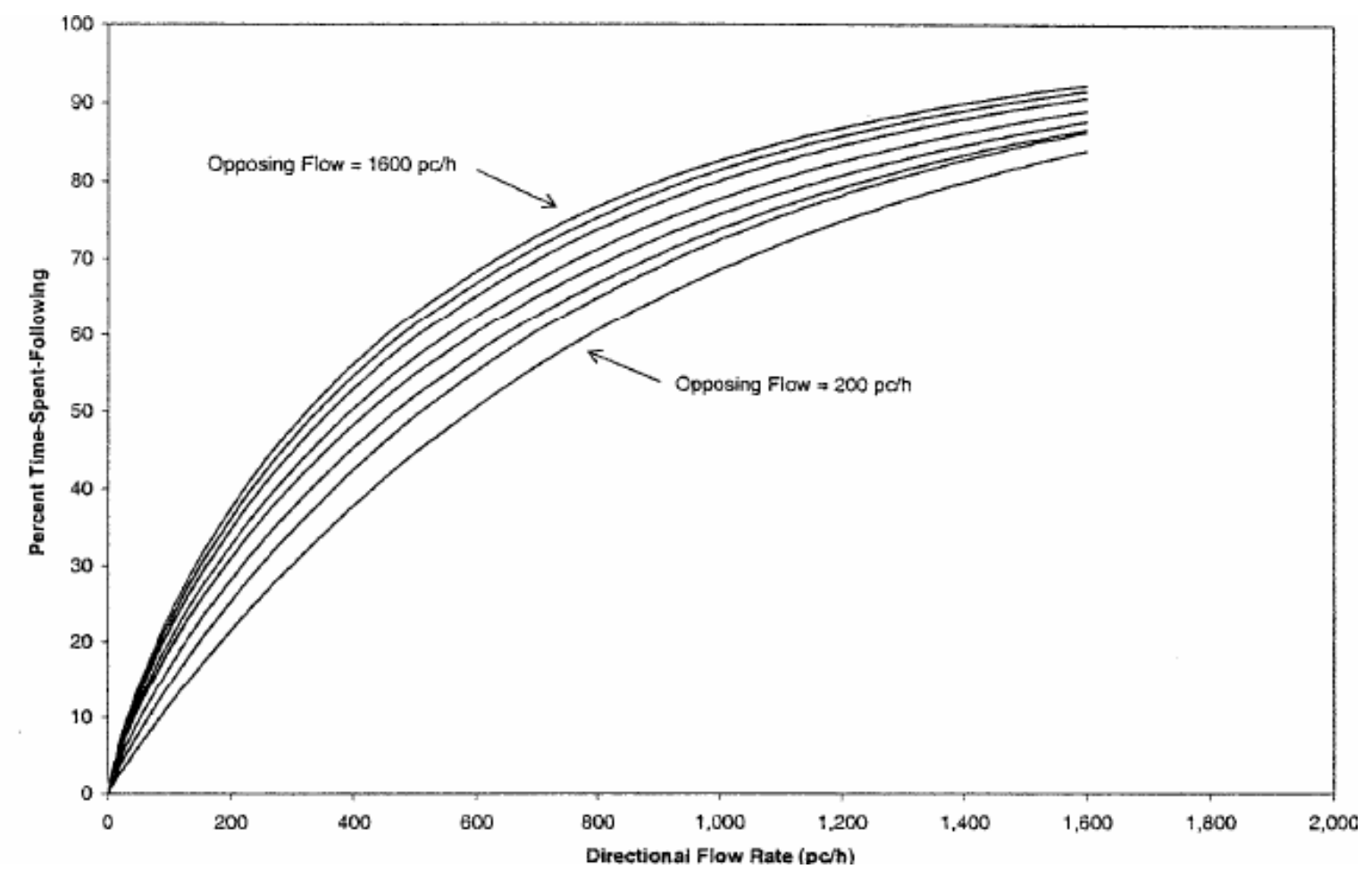

Slika 2.6. Predložene izmjene PTSF-a za jednosmjernu analizu s baznim uvjetima [H.1] 
Također su predložene promjene koeficijenta za zonu bez pretjecanja za jednosmjernu analizu i u najvećem dijelu su i prihvaćene u izdanju HCM 2010 (tablica 2.9).

Van As i Van Niekerk (2004) [V.1] su razvili novu metodologiju i makroskopski simulacijski model na temelju istraživanja provedenih u Južnoj Africi. Model je zasnovan na teoriji repova kako bi se simulirale promjene u koloni i duljine kolona. Uveli su pojam gustoće onih koji slijede $\mathrm{K}_{\mathrm{f}}$ (follower density) kao njihov broj po jediničnoj duljini dionice po jednom traku.

Problem primjene HCM-a i ostalih metodologija je bio što nisu mogli realno opisati prometni tok u Južnoj Africi koja pored ostalih prometnih specifičnosti ima i mogućnost pretjecanja bankinom. Analizirani su postotak onih koji slijede (PF), prometni tok onih koji slijede (tok pomnožen s PF-om), brzina putovanja, smanjenje brzine zbog toka (kao postotak brzine slobodnog toka), gustoća i zakašnjenja vozila zbog kolona.

Na kraju su predložili model i mjere efikasnosti koje omogućuju optimalan proračun RU za uvjete kakvi prevladavaju u Južnoj Africi:

$$
\mathrm{K}_{\mathrm{F}}=\mathrm{P}_{\mathrm{F}} \cdot \frac{\mathrm{Q}}{\mathrm{N} \cdot \mathrm{U}}
$$

Gdje su:

- $\quad \mathrm{K}_{\mathrm{F}}=$ gustoća onih koji slijede (broj onih koji slijede $/ \mathrm{km} / \mathrm{traku}$ )

- $\quad \mathrm{P}_{\mathrm{F}}=$ postotak onih koji slijede

- $\mathrm{Q}=$ prometni tok analiziranog smjera

- $\quad \mathrm{N}=$ broj trakova analiziranog smjera

- $\quad U=$ prosječna brzina

Ovaj model se pokazao prikladnim i za analize kada se poboljšanjem dionice povećava kapacitet, a isto tako je pouzdan za mala prometna opterećenja.

Luttinen, Dixon i Washburn (2005) [L.5] su analizirali HCM 2000 i zaključili su da postoje dva osnovna problema. Prvi je taj što jednosmjerna analiza daje veće vrijednosti od dvosmjerne, a drugi da se analize ne mogu primijeniti na dvotračne ceste izgrađenih područja.

Konačne prijedloge su dali kroz zaključke:

- u sljedećem izdanju HCM-a treba zadržati samo jednosmjernu analizu

- sljedeću metodu treba bolje terenski validirati.

Ovi prijedlozi su prihvaćeni i uvršteni u HCM 2010. 
Romana i Perez (2006) [R.3] su na temelju istraživanja provedenih na španjolskim cestama uveli graničnu (temeljnu) brzinu kao mjeru kvalitete toka. To je brzina koja je granično zadovoljavajuća za vozača te isti nema želju za pretjecanjem.

Predložili su da se za slučaj kada je prosječna brzina ATS veća od granične analizira i PTSF. Za obrnuti slučaj smatraju kako će kolone imati manji značaj za vozače od prosječne brzine. Slika 2.7 prikazuje način određivanja razine usluge na primjeru granične brzine $80 \mathrm{~km} / \mathrm{h}$.

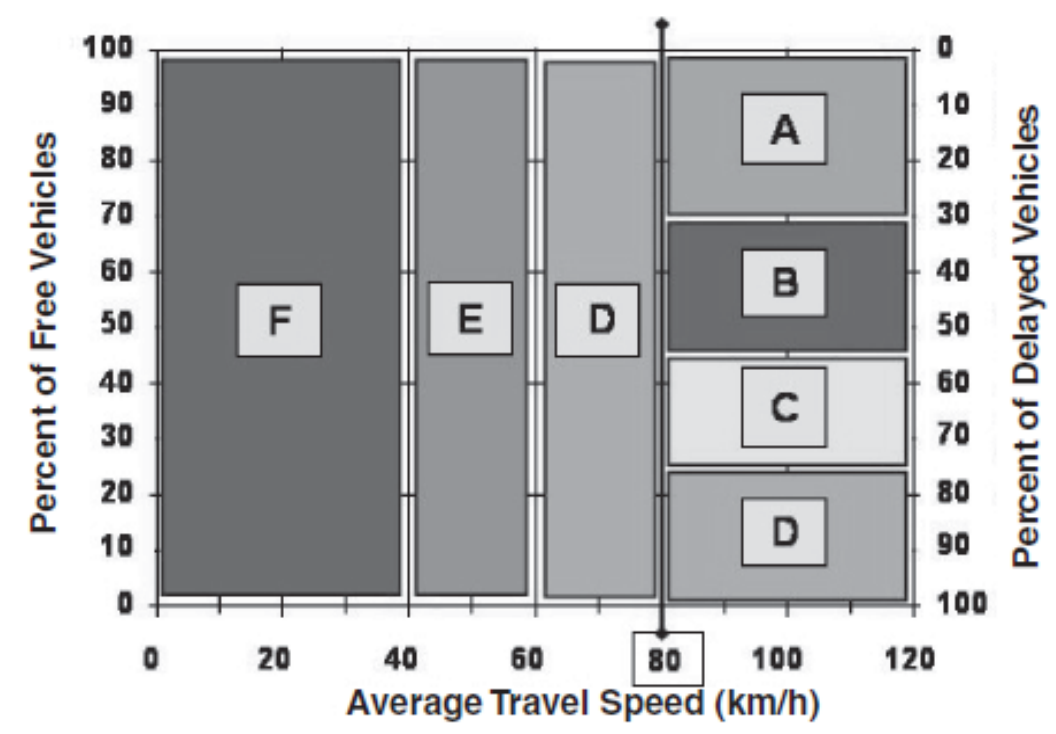

Slika 2.7. Primjer korištenja temeljne brzine na dvotračnim cestama [R.3]

Na slici se može vidjeti da za brzine manje od $80 \mathrm{~km} / \mathrm{h}$ razina usluge opada od D do F. Tek kada je zadovoljen slučaj da je prosječna brzina veća od granične razmatra se utjecaj kolone. U nastavku je dan prijedlog primjene i komparacija s HCM 2000 (Tablica 2.11).

Tablica 2.11. Poredba RU prema predloženom pristupu i HCM 2000 [R.3]

\begin{tabular}{|c|c|c|c|c|}
\hline \multirow[b]{2}{*}{ LOS } & \multirow[b]{2}{*}{$\begin{array}{c}\text { HCM } 2000 \\
\text { (Class } \mathrm{I} \text {, speed in } \mathrm{km} / \mathrm{h} \text { ) }\end{array}$} & \multirow[b]{2}{*}{$\begin{array}{l}\text { HCM } 2000 \\
(\mathrm{PTSF} \text { in \%) }\end{array}$} & \multicolumn{2}{|l|}{ Proposed } \\
\hline & & & $\begin{array}{c}\text { Speeds Greater } \\
\text { than Threshold, } \\
\qquad 80 \mathrm{~km} / \mathrm{h}\end{array}$ & $\begin{array}{c}\text { Speeds Lower } \\
\text { than Threshold } \\
80 \mathrm{~km} / \mathrm{h}\end{array}$ \\
\hline A & $>90$ & PTSF $\leq 35$ & $\% \mathrm{DV} \leq 30$ & - \\
\hline B & $80<\mathrm{s} \leq 90$ & $35<\mathrm{PTSF} \leq 50$ & $30<\% \mathrm{DV} \leq 55$ & - \\
\hline $\mathrm{C}$ & $70<\mathrm{s} \leq 80$ & $50<\mathrm{PTSF} \leq 65$ & $55<\% \mathrm{DV} \leq 75$ & - \\
\hline $\mathrm{D}$ & $60<s \leq 70$ & $65<$ PTSF $\leq 80$ & $75<\% \mathrm{DV}$ & $60<s \leq 80$ \\
\hline $\mathrm{E}$ & $40<s \leq 60$ & $80<$ PTSF & - & $40<\mathrm{s} \leq 60$ \\
\hline $\mathrm{F}$ & - & - & - & $\mathrm{s} \leq 40$ \\
\hline
\end{tabular}

$\% \mathrm{DV}=$ percentage of delayed vehicles. 
Brilon i Weiser (2006) [B.3] su analizirali prometne karakteristike dvotračnih cesta u Njemačkoj i iznijeli njihova iskustva. Njemačka metodologija je dana u HBS 2001 [F.1] (Handbuch fuer die Bemessung von Strassen) te praktički predstavlja njemačku verziju HCM-a.

U Njemačkoj prevladava stav da smjernice i pravilnici trebaju biti temeljeni na terenskim istraživanjima. To i jest razlog da HBS 2001, a niti novi HBS 2015, nemaju PTSF kao mjeru efikasnosti jer ga smatraju nemjerljivim.

Za njih bitan parametar je gustoća prometa (volumen podijeljen s prosječnom brzinom putovanja). Povećanje PTSF-a smatra se kao izraz neugodnosti vozača koje izravno ne izražavaju stupanj efikasnosti odvijanja prometa. Parametri sigurnosti, kvalitete sustava upravljanja i ekološki su ti koji definiraju politiku upravljanja cestama.

Stoga su dijagrami brzina - tok temelj za planiranje i projektiranje. Za razliku od HCM-a, prometni tok se izražava preko vozila po satu, a ne osobnih vozila po satu (PCE). Umjesto toga, teška vozila (sva preko $3500 \mathrm{~kg}$ ) se izražavaju kao postotak od ukupnog broja vozila (PHV).

Veliku ulogu igra brzina, kao i geometrija ceste izražena preko krivinske karakteristike (KU) razvrstane u 4 razreda i uzdužni nagibi koji su definirani preko 5 razreda. U tablici 2.12 prikazani su navedeni parametri te su za različite kombinacije utjecajnih parametara izrađeni dijagrami brzina-tok na temelju kojih se utvrđuje RU.

Tablica 2.12. Kombinacija parametara za određivanje brzina-tok dijagrama [B.3]

\begin{tabular}{|cccccc|}
\hline \multicolumn{7}{c|}{ Class of Gradient } \\
\hline & 1 & 2 & 3 & 4 & 5 \\
\hline$v_{\mathrm{HV}}[\mathrm{km} / \mathrm{h}]$ & $>70$ & $>55$ & $>40$ & $>30$ & $<30$ \\
Curvature $\mathrm{KU}^{\mathrm{a}}[$ degrees $/ \mathrm{km}]$ & & & & & \\
$0-67$ & Level, straight & $\mathrm{x}$ & $\mathrm{x}$ & $\mathrm{x}$ & $\mathrm{x}$ \\
$67-135$ & $\mathrm{x}$ & $\mathrm{x}$ & $\mathrm{x}$ & $\mathrm{x}$ & $\mathrm{x}$ \\
$135-202$ & $\mathrm{x}$ & $\mathrm{x}$ & $\mathrm{x}$ & $\mathrm{x}$ & $\mathrm{x}$ \\
$>202$ & $\mathrm{x}$ & $\mathrm{x}$ & $\mathrm{x}$ & $\mathrm{x}$ & Alpine \\
\hline
\end{tabular}

Posljednje izdanje HBS 2015 također je definiran na istim principima, osim što je uzdužni nagib također predstavljen u 4 razreda i nema utjecaja pretjecanja.

Al-Kaisy i Durbin (2007-2008) [A.2, A.3] (Montana, SAD) su definirali PTSF preko novih pristupa koji su uključivali probabilistički pristup i metodu prosječne težine (WeightedAverage Method). Probabilistički pristup odredeđuje vjerojatnost da se vozila voze brzinom manjom od željene i daje bolje rezultate od metode prosječne težine. Metoda prosječne težine je temeljena na srednjim brzinama i srednjim željenim brzinama pojedinih klasa vozila. 
Probabilistička metoda se temelji na dvije varijable koje se koriste za određivanje PF-a. Te varijable su vjerojatnost da je vozilo dio kolone $\left(\mathrm{P}_{\mathrm{p}}\right)$ i vjerojatnost da vozi brzinom manjom od željene $\left(\mathrm{P}_{\mathrm{i}}\right)$. Time se PF (ujedno i PTSF) dobije iz izraza:

$$
\mathrm{PF}=\mathrm{P}_{\mathrm{p}} \times \mathrm{P}_{\mathrm{i}}
$$

$P_{p}$ je vjerojatnost da je vozilo dio kolone (za granično vrijeme slijeda od $3 \mathrm{~s}$ ), dok $P_{i}$ uključuje ovisnost brzine vozila o značajno sporijim vozilima ispred njih kao i onim koja voze malo sporije od željene brzine bez želje za pretjecanjem. Mjerenjem u presjeku može se dobiti da je brzina vozila koja slijede manja od sporog vozila na čelu kolone pa se stoga preporučuje mjerenje prosječne brzine slobodnog vozila i definiranje distribucije željenih brzina svih vozila.

Na slici 2.8 prikazana je vjerojatnost $P_{i}$ normalne razdiobe željene brzine. Zaključak je bio da prosječna brzina sporih vozila (preko razdiobe željene brzine) može poslužiti za određivanje postotka vozila sa željenom brzinom većom od prosječne brzine sporih vozila. Na ovaj način se može odrediti $\mathrm{P}_{\mathrm{i}}$.

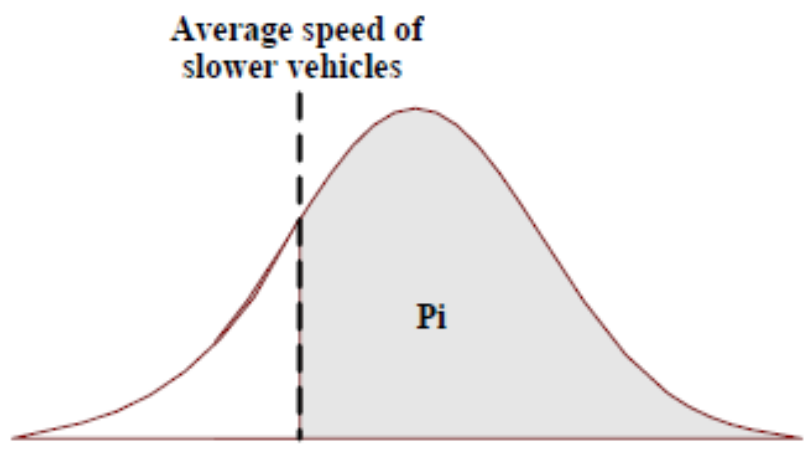

Desired speed

Slika 2.8. Teorijska distribucija brzine za predstavljanje vjerojatnosti $\mathrm{P}_{\mathrm{i}}$ [A.2]

Kao rezultat terenskih istraživanja lineranom regresijom dobio se izraz: $\mathrm{PF}=0.05784(\mathrm{voz} / \mathrm{h}$ analiziranog smjera $)+0.00799(\mathrm{voz} / \mathrm{h}$ suprotnog smjera $)+1.48486(\%$ teških vozila $)+0.11363(\%$ zona bez pretjecanja $)$

Metoda prosječne težine (Weighted-Average Method) se temelji na postavci da postoje dvije grupe vozila, teška (teretna, autobusi, rekreacijska) s manjim i osobna s većim prosječnim brzinama. Preporučena metoda analizira srednju brzinu putovanja i srednju željenu brzinu za sve grupe vozila. Analiziraju se:

- $\quad S_{\text {apv }}=$ srednja brzina putovanja osobnih vozila (Mean actual travel speed of passenger vehicles)

- $\quad \mathrm{S}_{\mathrm{ahv}}=$ srednja brzina putovanja teških vozila (Mean actual travel speed of heavy vehicles) 
- $\quad \mathrm{S}_{\mathrm{dpv}}=$ srednja željena brzina osobnih vozila (Mean desired travel speed of passenger vehicles)

- $\quad \mathrm{S}_{\mathrm{dhv}}=$ srednja željena brzina teških vozila (Mean desired travel speed of heavy vehicles)

- $\quad S_{\text {atot }}=$ srednja brzina svih vozila (Mean actual travel speed of all vehicles)

Metoda pretpostavlja da teška vozila nisu ovisna o osobnim, dok je moguć obrnuti slučaj. $\mathrm{Na}$ osnovu toga se može pretpostaviti da su srednja brzina putovanja teških vozila i srednja željena brzina teških vozila približno jednake:

$$
\mathrm{S}_{\mathrm{ahv}} \approx \mathrm{S}_{\mathrm{dhv}}
$$

Srednja brzina svih vozila se može izraziti kao:

$$
\mathrm{S}_{\mathrm{atot}}=\mathrm{S}_{\mathrm{apv}} \times \mathrm{P}_{\mathrm{pv}}+\mathrm{S}_{\mathrm{ahv}} \times \mathrm{P}_{\mathrm{hv}}
$$

U jednadžbi $\mathrm{P}_{\mathrm{pv}}$ i $\mathrm{P}_{\mathrm{hv}}$ predstavljaju postotke osobnih i teških vozila u mješovitom prometu.

Metoda dijeli osobna vozila na ona koja voze željenom brzinom i ona koja ovise o sporijim vozilima i voze sporije od željene brzine. Iz toga se dobije:

$$
\begin{gathered}
\mathrm{S}_{\mathrm{atot}}=\mathrm{S}_{\mathrm{dpv}} \times \mathrm{P}_{\mathrm{pv} 1}+\mathrm{S}_{\mathrm{ipv}} \times \mathrm{P}_{\mathrm{pv} 2}+\mathrm{S}_{\mathrm{ahv}} \times \mathrm{P}_{\mathrm{hv}} \\
\mathrm{P}_{\mathrm{pv}}=\mathrm{P}_{\mathrm{pv} 1}+\mathrm{P}_{\mathrm{pv} 2}
\end{gathered}
$$

- $\quad \mathrm{P}_{\mathrm{pv} 1}=$ udio osobnih vozila koji vozi željenom brzinom (Proportion of passenger vehicles traveling at desired speeds)

- $\mathrm{P}_{\mathrm{pv} 2}=$ udio osobnih vozila ovisnih o sporim vozilima (Proportion of passenger vehicles impeded by slower vehicles)

- $\quad \mathrm{S}_{\mathrm{ipv}}=$ srednja brzina osobnih vozila ovisnih o sporim vozilima (Mean speed of passenger vehicles impeded by slower vehicles)

$\mathrm{P}_{\mathrm{pv} 1}$ predstavlja postotak osobnih vozila koji vozi željenom brzinom u koloni i izvan kolone.

Pretpostavka je da srednja brzina osobnih vozila u koloni je jednaka srednjoj brzini sporih vozila i dobije se:

$$
\mathrm{S}_{\mathrm{atot}} \approx \mathrm{S}_{\mathrm{dpv}} \times \mathrm{P}_{\mathrm{pv} 1}+\mathrm{S}_{\mathrm{ahv}} \times \mathrm{P}_{\mathrm{hv} 2}+\mathrm{S}_{\mathrm{ahv}} \times \mathrm{P}_{\mathrm{hv}}
$$

Iz toga slijedi:

$$
\mathrm{S}_{\mathrm{atot}} \approx \mathrm{S}_{\mathrm{dpv}} \mathrm{x} \mathrm{P}_{\mathrm{pv} 1}+\mathrm{S}_{\mathrm{ahv}}\left(\mathrm{P}_{\mathrm{hv} 2}+\mathrm{P}_{\mathrm{hv}}\right)
$$

Na kraju se može napisati:

$$
\mathrm{S}_{\mathrm{atot}} \approx \mathrm{S}_{\mathrm{dpv}} \mathrm{x}\left(\mathrm{P}_{\mathrm{pv}}-\mathrm{P}_{\mathrm{pv} 2}\right)+\mathrm{S}_{\mathrm{ahv}}\left(\mathrm{P}_{\mathrm{hv} 2}+\mathrm{P}_{\mathrm{hv}}\right)
$$

Parametri koji čine ovaj izraz su lako mjerljivi i na terenu. 
Kao rezultat terenskih istraživanja lineranom regresijom se dobio izraz:

$\mathrm{PF}=0.04716(\mathrm{voz} / \mathrm{h}$ analiziranog smjera $)+0.002104(\mathrm{voz} / \mathrm{h}$ suprotnog smjera $)+1.22248(\%$ teških vozila $)+0.31156(\%$ zona bez pretjecanja $)$

Al-Kaisy i Karjala (2008) [A.4] svoja su istraživanja proveli u Montani (SAD) i analizirali su sljedeće parametre:

- ATS - prosječnu brzinu putovanja

- ATS $_{\mathrm{PC}}$ - prosječnu brzinu putovanja osobnih vozila

- ATS/FFS - prosječnu brzinu kao postotak brzine slobodnog toka

- $\quad \mathrm{ATS}_{\mathrm{PC}} / \mathrm{FFS}$ - prosječnu brzinu osobnih vozila kao postotak brzine slobodnog toka

- $\mathrm{ATS}_{\mathrm{PC}} / \mathrm{FFS}_{\mathrm{PC}}$ - prosječnu brzinu osobnih vozila kao postotak brzine slobodnog toka osobnih vozila

- PD - postotak onih koji slijede

- FD - gustoća onih koji slijede

Najbolju korelaciju je davao parametar FD $\left(\mathrm{R}^{2}=0.98\right)$ :

Follower Density $=0.01041$ (voz/h analiziranog smjera) - 0.00022 (voz/h suprotnog smjera) 0.03057 (\% teških vozila) $+0.00500(\%$ zona bez pretjecanja $)+0.11670$ (standardna devijacija brzine slobodnog toka)

Manju korelaciju $\left(\mathrm{R}^{2}=0.62\right)$ je dao parametar PF:

$\%$ Followers $=0.03380(\mathrm{voz} / \mathrm{h}$ analiziranog smjera $)+0.00607$ (voz/h suprotnog smjera) 0.16062 (\%teških vozila) +0.10894 (\%zona bez pretjecanja) +2.12739 (standardna devijacija brzine slobodnog toka)

Polus i Cohen (2009) [P.2] su u istraživanjima provedenim u Izraelu povezali teorijske i empirijske pristupe za određivanje razine usluge. Naglasak je bio na proučavanju kolone i položaja vozila u koloni (slika 2.9).

Definirali su 5 glavnih parametara, prometni tok, prosječna duljina kolone (average platoon length APL), intenzitet prometa $(\rho)$, PTSF i sloboda toka (freedom of flow $\eta$ ). Kao nova mjera efikasnosti predložena je sloboda toka (freedom of flow $\eta$ ), a predložene su i korekcije PTSF-a. 


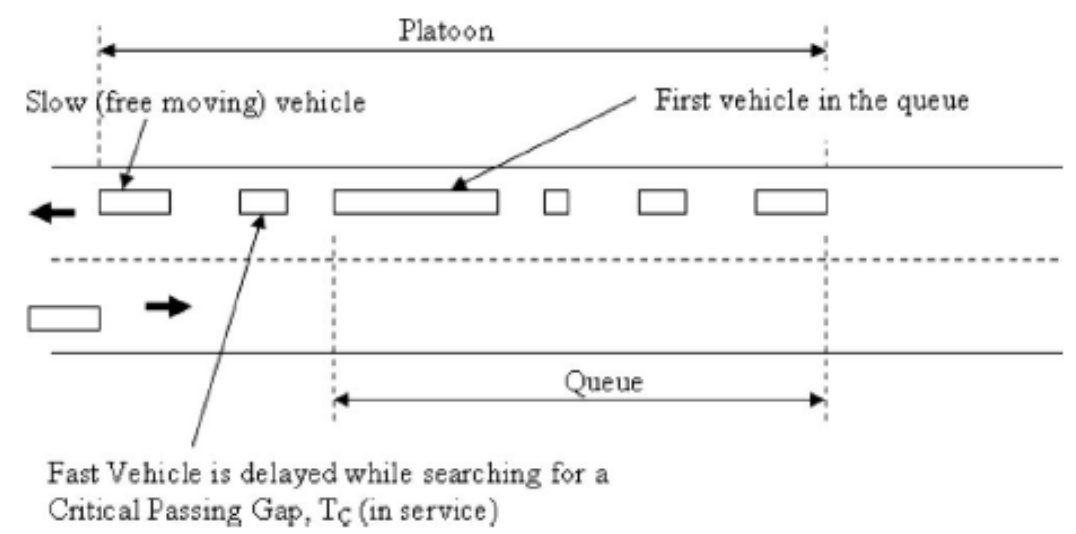

Slika 2.9. Šematski prikaz kolone [P.2]

PTSF je definiran kao:

$$
\mathrm{PTSF}=100\left(\mathrm{Q}_{0}-1\right) /\left(\mathrm{Q}_{0}+\mathrm{N}_{0}-1\right)
$$

Gdje su:

- $\quad \mathrm{N}_{0}=$ prosječni broj vremena slijeda između kolona (bezdimenzionalni broj)

- $\quad \mathrm{Q}_{0}=$ prosječni broj vremena slijeda u koloni (bezdimenzionalni broj)

Također je dat izraz na osnovu kalibriranih vrijednosti:

$$
\operatorname{PTSF}=100 \cdot\left(1-\mathrm{e}^{\left(-0.000504 \mathrm{~V}_{\mathrm{p}}\right)}\right)
$$

Gdje je:

- $\quad \mathrm{V}_{\mathrm{p}}=$ dvosmjerni prometni tok $(\mathrm{ov} / \mathrm{h})$

Na slici 2.10 prikazan je dobiveni model PTSF-a za dvosmjerni promet u komparaciji s HCM 2000 modelom.

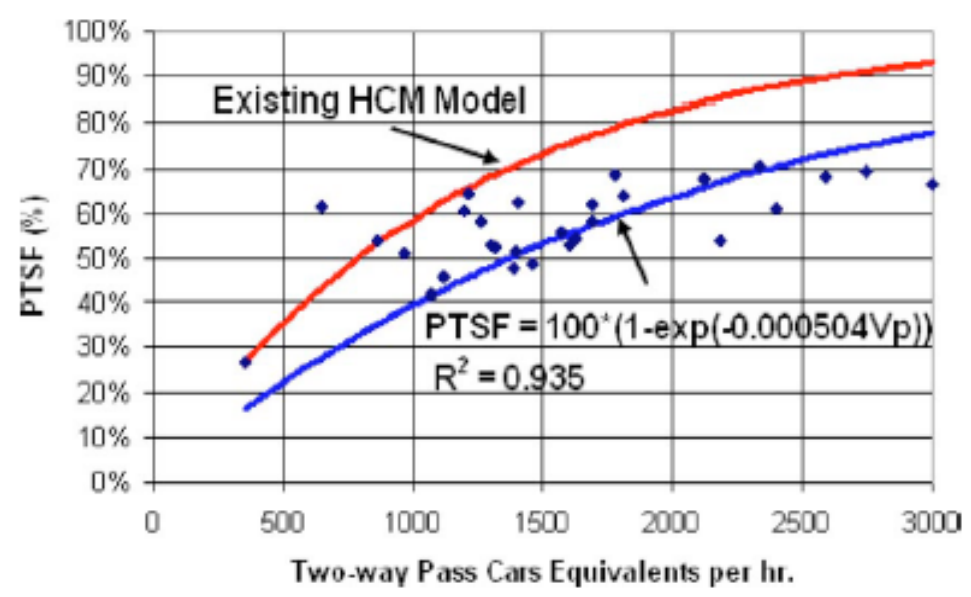

Slika 2.10. Predloženi model PTSF-a za dvosmjernu analizu u komparaciji s HCM 2000 [P.2]

Na slici se mogu vidjeti značajno manji rezultati predloženog modela u odnosu na HCM 2000. Uz predloženi model, date su i vrijednosti za mjere efikasnosti (tablica 2.13). 
Tablica 2.13. Preporučene vrijednosti PTSF-a i slobode toka za dvotračne ceste [P.2]

\begin{tabular}{|c|c|c|c|}
\hline \multicolumn{3}{|c|}{ Level of service } & Proposed \\
\hline $\begin{array}{c}\text { Level of } \\
\text { service }\end{array}$ & PTSF (\%) & $\begin{array}{c}\text { Two-way flow } \\
(\mathrm{pcph})\end{array}$ & $\begin{array}{c}\text { Freedom of } \\
\text { flow (Eta) }\end{array}$ \\
\hline A & $0-15$ & $0-300$ & $\geq 16.5$ \\
B & $15-30$ & $300-700$ & $7.1-16.5$ \\
C & $30-45$ & $700-1200$ & $4.1-7.1$ \\
D & $45-60$ & $1200-1800$ & $2.8-4.1$ \\
E & $60-75$ & $1800-2700$ & $1.8-2.8$ \\
F & $75-100$ & $\geq 2700$ & $\leq 1.8$ \\
\hline
\end{tabular}

Yu i Washburn (2009) [Y.1] su razvili metodu za dvotračne ceste koja omogućuje proračun za gotovo sve situacije, pa čak i za slučajeve signaliziranih raskrižja. Dionica se podijeli na dijelove bez utjecaja i dijelove s utjecajem raskrižja. Kao mjeru efikasnosti za određivanje razine usluge predložili su postotak zakašnjenja PD (precent delay) i definirali ga kao:

$$
\mathrm{PD}=\frac{\sum_{\mathrm{H}, \mathrm{S}}\left(\mathrm{D}_{\mathrm{H}}+\mathrm{D}_{\mathrm{S}}\right)}{\sum_{\mathrm{H}, \mathrm{S}}\left(\frac{\mathrm{L}_{\mathrm{H}}}{\mathrm{FFS}_{\mathrm{H}}}+\frac{\mathrm{L}_{\mathrm{S}}}{\mathrm{FFS}_{\mathrm{S}}}\right)} \cdot 100
$$

Gdje su:

- $\quad$ PD = postotak zakašnjenja po vozilu za cijelu dionicu (\%)

- $\quad D_{H}=$ prosječno zakašnjenje po vozilu za dvotračni segment dionice (sekundi/voz)

- $\quad D_{S}=$ prosječno zakašnjenje po vozilu za segment s utjecajem signaliziranog raskrižja (sekundi/voz)

- $\quad \mathrm{FFS}_{\mathrm{H}}=$ prosječna brzina slobodnog toka za dvotračni segment dionice $(\mathrm{m} / \mathrm{s})$

- $\mathrm{FFS}_{\mathrm{S}}=$ prosječna brzina slobodnog toka za segment $\mathrm{s}$ utjecajem signaliziranog raskrižja $(\mathrm{m} / \mathrm{s})$

- $\quad \mathrm{L}_{\mathrm{H}}=$ duljina dvotračnog segmenta dionice $(\mathrm{m})$

- $\quad \mathrm{L}_{\mathrm{S}}=$ duljina segmenta s utjecajem signaliziranog raskrižja $(\mathrm{m})$.

Ova mjera efikasnosti također (kao i PTSF) opisuje percepciju slobode manevriranja vozača. U tablici 2.14 date su granične vrijednosti za definiranje RU. 
Tablica 2.14. Preporučene vrijednosti PD-a za određivanje RU [Y.1]

\begin{tabular}{|c|c|}
\hline Level of service & Percent Delay (\%) \\
\hline A & $\leq 7.5$ \\
B & $>7.5-15$ \\
C & $>15-25$ \\
D & $>25-35$ \\
E & $>35-45$ \\
F & $>45$ \\
\hline
\end{tabular}

Cohen i Polus (2011) [P.3] su nastavili istraživanja i razvoj modela iz 2009. godine [P.2]. Urađena su dodatna terenska istraživanja na 71 lokaciji i uvedene su neke drugačije pretpostavke u analizu. Prva pretpostavka je da su brzine vozila konstantne (brzo vozilo „s“ i sporo vozilo „u“). Predložili su novi način proračuna PTSF-a zasnovan na probabilističkom pristupu analize kolona i vremena slijeda (slike 2.11, 2.12 i 2.13). Parametri za definiranje PTSF-a su prosječni broj vremena slijeda izvan kolona i prosječni broj vremena slijeda unutar kolona.

Drugi preduvjet je da nema priključaka i ujednačenost geometrije. Treći uvjet je tok u stacionarnom stanju (slika 2.11).

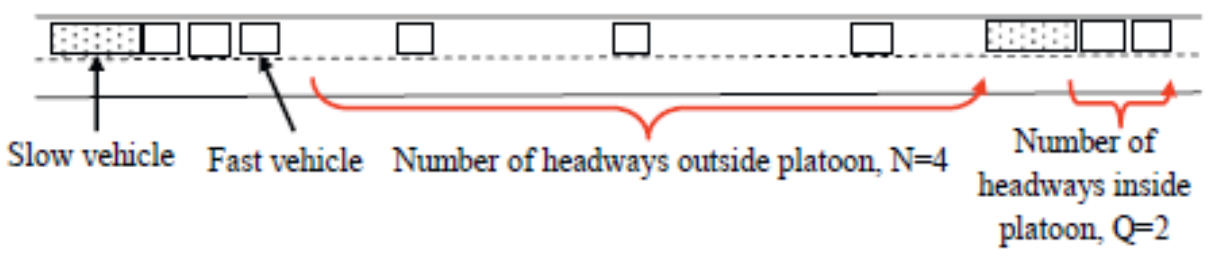

Slika 2.11. Shematski prikaz definiranja kolona za jednosmjernu analizu [P.3]

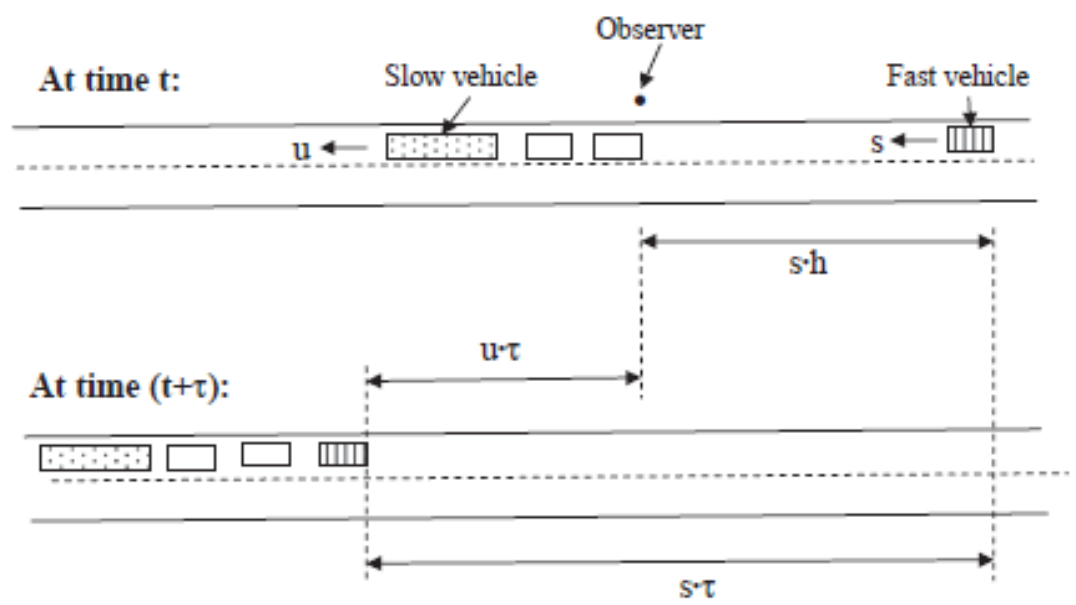

Slika 2.12. Šematski prikaz snimanja kolone [P.3] 
Duljina koju brzo vozilo prijeđe $u$ sustizanju sporog je $s \cdot \tau$. Parametar $h$ je vrijeme slijeda između posljednjeg vozila u koloni i brzog koje ga sustiže.

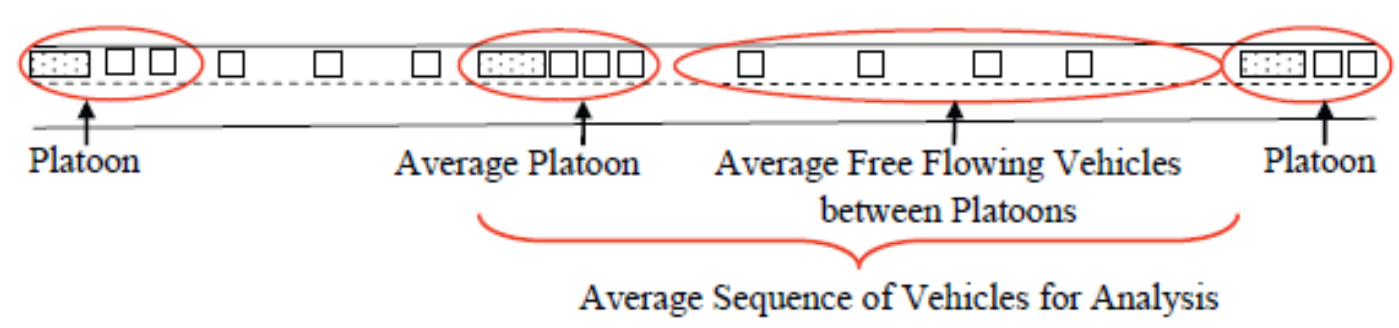

Slika 2.13. Definiranje vozila u koloni za analizu [P.3]

Određivanje PTSF-a moguće je na način da se definira slijed vozila u koloni kao i prosječni broj vozila koja voze slobodno. Vrijeme koje prođe dok brzo vozilo čeka prazninu za pretjecanje sporog vozila nazvano je "service“ (usluga). Korišten je M/M/1 model iz teorije repova (analogija s nesemaforiziranim raskrižjima), gdje su pretpostavljene slučajne razdiobe dolazaka i usluge. PTSF je u konačnosti definiran kao:

$$
\mathrm{PTSF}=\left\{\begin{array}{c}
100 \cdot \frac{\overline{\mathrm{Q}}}{\overline{-}-\overline{\mathrm{Q}}}, \pi=0 \\
100 \cdot \frac{\overline{\mathrm{Q}}}{\overline{\mathrm{N}}+\overline{\mathrm{Q}}}, \pi=1-\rho \\
100 \cdot \frac{\overline{\mathrm{Q}}}{\overline{\mathrm{N}}+\overline{\mathrm{Q}}}, \pi=\operatorname{Prob}\{\mathrm{Q}=2\}
\end{array}\right.
$$

Gdje su:

- $\quad \overline{\mathrm{Q}}=$ prosječni broj vremena slijeda u koloni

- $\quad$ Q = broj vremena slijeda u koloni

- $\quad \overline{\mathrm{N}}=$ prosječni broj vremena slijeda između dvije kolone

- $\pi=$ vjerojatnost da sporo vozilo nema kolonu iza sebe

- $\quad \rho=$ intenzitet prometa

Grafikon na slici 2.14 prikazuje PTSF u funkciji prometnog toka za prva dva slučaja, te prema HCM modelu. 


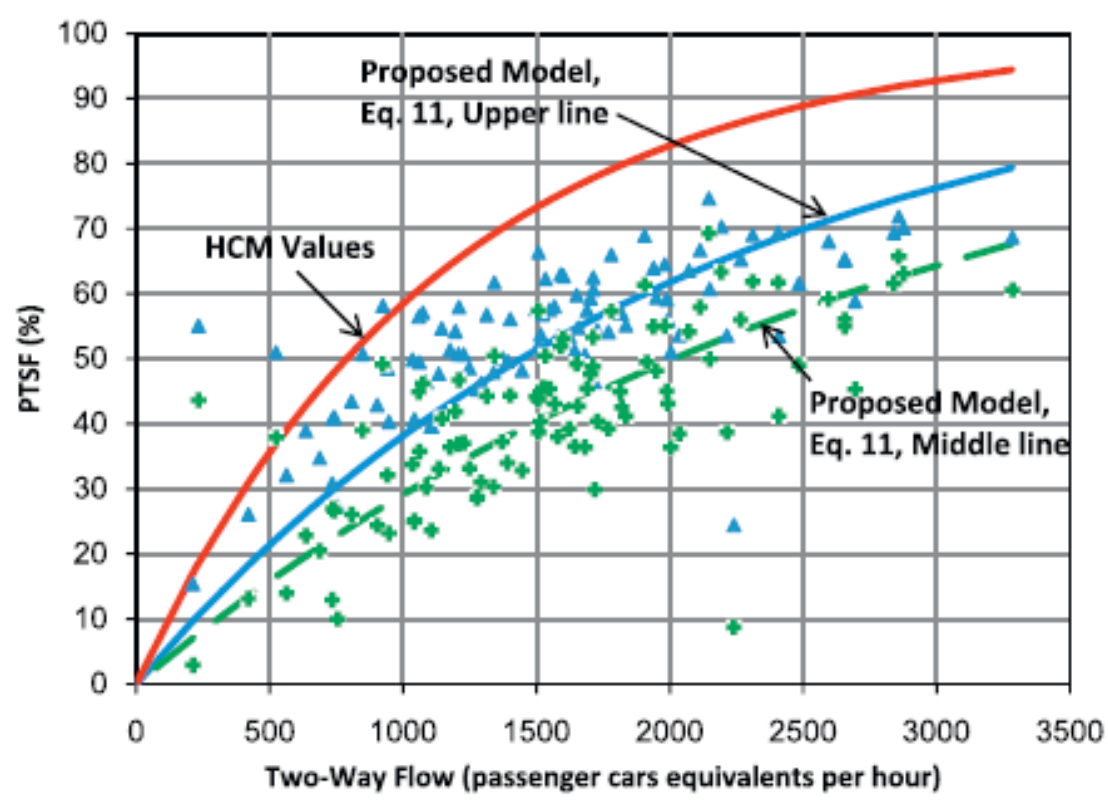

Slika 2.14. Predloženi model PTSF-a za dvosmjerni promet i HCM model [P.3]

Moreno i drugi (2014) [M.1] su radili istraživanja na dvotračnim cestama u Španjolskoj. Analizirali su veliki broj mjera efikasnosti i drugih parametara, te su definirali najprikladnije statističke razdiobe (normalna, log-normalna, inverzna) za primjenu u analizi. Korelacije mjera efikasnosti i statističkih razdioba prikazane su u tablici 2.15 .

Tablica 2.15. Korelacije mjera efikasnosti i statističkih razdioba [M.1]

\begin{tabular}{|c|c|c|c|c|c|c|}
\hline \multicolumn{2}{|c|}{} & \multirow{2}{*}{$\begin{array}{c}\text { Better } \\
\text { Adjustment }\end{array}$} & \multicolumn{2}{c|}{ Normal } & \multicolumn{2}{c|}{ Transformed scale } \\
\cline { 5 - 7 } & Average & $\begin{array}{c}\text { Standard } \\
\text { deviation }\end{array}$ & Average & $\begin{array}{c}\text { Standard } \\
\text { deviation }\end{array}$ \\
\hline $\begin{array}{c}\text { Two-way traffic } \\
\text { flow }\end{array}$ & $\log (\mathrm{V})$ & Lognormal & 220 & 47.92 & 4.624 & 0.414 \\
\hline Traffic proportion & Prop & Normal & 49.94 & 7.31 & - & - \\
\hline Direct traffic flow & $\log (\mathrm{Vd})$ & Lognormal & 55.38 & 25.46 & 3.918 & 0.438 \\
\hline $\begin{array}{c}\text { Opposing traffic } \\
\text { flow }\end{array}$ & Log(Vo) & Lognormal & 55.53 & 25.55 & 3.921 & 0.438 \\
\hline $\begin{array}{c}\text { Percentage trucks } \\
\text { Average travel } \\
\text { speed 100 }\end{array}$ & \%HGV & Normal & 14.58 & 9.47 & - & - \\
\hline $\begin{array}{c}\text { Average travel } \\
\text { speed 80 }\end{array}$ & ATS80 & Normal & 75.94 & 2.30 & - & - \\
\hline $\begin{array}{c}\text { Average travel } \\
\text { speed PC 100 }\end{array}$ & ATSpc100 & Normal & 102.77 & 6.20 & - & - \\
\hline $\begin{array}{c}\text { Average travel } \\
\text { speed PC 80 }\end{array}$ & ATSpc80 & Normal & 76.22 & 2.42 & - & - \\
\hline $\begin{array}{c}\text { Percent free flow } \\
\text { speed }\end{array}$ & PFFS & Normal & 0.98 & 0.04 & - & - \\
\hline $\begin{array}{c}\text { Percent free flow } \\
\text { speed PC }\end{array}$ & PFFSpc & Normal & 1.00 & 0.03 & - & - \\
\hline
\end{tabular}




\begin{tabular}{|c|c|c|c|c|c|c|}
\cline { 2 - 6 } Following vehicles & $\mathrm{NB}(\mathrm{FV})$ & $\begin{array}{c}\text { Negative } \\
\text { binomial }\end{array}$ & 22.09 & 17.19 & - & - \\
\hline Percent followers & $\mathrm{PF}$ & Normal & 35.03 & 13.52 & & \\
\hline Follower density & $\mathrm{Log}(\mathrm{FD})$ & Lognormal & 0.24 & 0.27 & -1.807 & 0.895 \\
\hline Percent impeded & $\mathrm{PI}$ & Normal & 23.64 & 13.08 & - & - \\
\hline $\begin{array}{c}\text { Average platoon } \\
\text { length }\end{array}$ & $1 / \mathrm{APL}$ & Inverse & 2.72 & 0.54 & 0.381 & 0.068 \\
\hline Traffic intensity & $\rho$ & Normal & 0.36 & 0.18 & - & - \\
\hline Freedom of flow & $1 / \mu$ & Inverse & 18.74 & 25.43 & 0.130 & 0.092 \\
\hline
\end{tabular}

Na osnovu njih su dobili izraze s pripadajućim stupnjem determiniranosti (tablica 2.16).

Tablica 2.16. Dobiveni izrazi za proračun mjera efikasnosti na španjolskim cestama [M.1]

\begin{tabular}{|c|l|c|c|}
\hline Variable & Equation & $\mathbf{R}^{\mathbf{2}} \mathbf{( \% )}$ & $\mathbf{R}_{\text {adj }}^{\mathbf{2}} \mathbf{( \% )}$ \\
\hline $\mathrm{ATS}_{100}$ & $\mathrm{ATS}_{100}=129.265-6.03 \cdot \ln (\mathrm{Vd})-0.314 \cdot \% \mathrm{HGV}$ & 16.54 & 16.14 \\
\hline $\mathrm{ATS}_{80}$ & $\mathrm{ATS}_{80}=87.644-2.606 \cdot \ln (\mathrm{Vd})$ & 9.19 & 7.48 \\
\hline $\mathrm{ATSpc}_{100}$ & $\mathrm{ATSpc}_{100}=140.12-8.555 \cdot \ln (\mathrm{Vd})-0.288 \cdot \% \mathrm{HGV}$ & 16.62 & 16.22 \\
\hline $\mathrm{ATSpc}_{80}$ & $\mathrm{ATSpc}_{80}=89.295-2.912 \cdot \ln (\mathrm{Vd})$ & 10.22 & 8.56 \\
\hline $\mathrm{PFFS}$ & $\mathrm{PFFS}=1.233-0.056 \cdot \ln (\mathrm{Vd})-0.002 \cdot \% \mathrm{HGV}$ & 18.36 & 18.01 \\
\hline $\mathrm{PFFSpc}$ & $\mathrm{PFFSpc}=1.113-0.030 \cdot \ln (\mathrm{Vd})+0.001 \cdot \% \mathrm{HGV}$ & 34.12 & 34.84 \\
\hline $\mathrm{FV}$ & $\mathrm{FV}=\mathrm{exp}(-3.0834+1.5308 \cdot \ln (\mathrm{Vd})-0.0051 \cdot \% \mathrm{HGV})$ & 96.61 & 96.30 \\
\hline $\mathrm{PF}$ & $\mathrm{PF}=-60.693+24.4293 \cdot \ln (\mathrm{Vd})$ & 62.65 & 62.57 \\
\hline \multirow{2}{*}{$\mathrm{FD}$} & $\ln (\mathrm{FD})=-9.5670+1.9610 \cdot \ln (\mathrm{Vd})+0.0051 \cdot \% \mathrm{HGV}$ & 85.72 & 85.65 \\
\cline { 2 - 4 } & $\mathrm{FD}=-0.2083+0.0080 \cdot \mathrm{Vd}-0.0003 \cdot \mathrm{Vo}+0.0012 \cdot \% \mathrm{HGV}$ & 94.84 & 94.81 \\
\hline $\mathrm{PI}$ & $\mathrm{PI}=-36.728+15.7086 \cdot \ln (\mathrm{Vd})-0.1123 \cdot \% \mathrm{HGV}$ & 58.99 & 58.73 \\
\hline $\mathrm{APL}$ & $1 / \mathrm{APL}=0.663-0.093 \cdot \ln (\mathrm{Vd})-0.001 \cdot \% \mathrm{NPZ}$ & 36.00 & 35.73 \\
\hline$\rho$ & $\rho=-0.117+0.174 \cdot \ln (\mathrm{Vd})-0.002 \cdot \% \mathrm{HGV}-0.003 \cdot \% \mathrm{NPZ}$ & 33.80 & 33.34 \\
\hline$\mu$ & $1 / \mu=-0.325+0.145 \cdot \ln (\mathrm{Vd})-0.002 \cdot \% \mathrm{NPZ}$ & 49.90 & 49.67 \\
\hline
\end{tabular}

Analize su urađene za vremenske intervale 15 minuta i kao što se iz tablice može vidjeti najbolje korelacije su pokazali parametri broj vozila koja slijede FV (followers per period), postotak onih koji slijede PF (percent followers per period) i gustoća onih koji slijede FD (follower density per period). 
Penmetsa i drugi (2015) [P.5] su radili istraživanja u Indiji. Urađena su snimanja na tri dionice koje pripadaju klasi I prema HCM-u i analizirane su sljedeće mjere efikasnosti:

- prosječna brzina putovanja (ATS),

- prosječna brzina putovanja osobnih vozila $\left(\mathrm{ATS}_{\mathrm{PC}}\right)$,

- postotak brzine slobodnog toka (PFFS),

- prosječna brzina osobnih vozila kao postotak brzine slobodnog toka osobnih vozila $\left(\mathrm{ATS}_{\mathrm{PC}} / \mathrm{FFS}_{\mathrm{PC}}\right)$

- postotak onih koji slijede PF

- gustoća onih koji slijede FD

Prema definiciji (Van As u Južnoj Africi) FD je broj onih koji slijede po jedinici duljine (obično $1 \mathrm{~km}$ ) i računa se:

$$
\begin{aligned}
\operatorname{Density}(\mathrm{D}) & =\frac{\operatorname{Flow}(\mathrm{PCU} / \mathrm{h})}{\mathrm{ATS}} \\
\text { Follower density }(\mathrm{FD}) & =\text { Density }(\mathrm{D}) \cdot \text { Percent followers }(\mathrm{PF})
\end{aligned}
$$

Gdje su:

- $\quad \mathrm{D}=$ gustoća

- FD = gustoća onih koji slijede

Broj onih koji slijede (number of followers NF) je definiran preko vremena slijeda $2.6 \mathrm{~s}$, za razliku od vremena slijeda 3 s prema HCM-u. Parametar NF je davao pouzdane rezultate, ali nije dovoljno opisivao uvjete prometnog toka. NF može biti jednak na dvije ceste koje imaju sličan volumen, ali će biti više zagušenja na onoj s manjim kapacitetom.

Stoga je uveden broj onih koji slijede kao udio (tablica 2.17) kapaciteta (number of followers as a proportion of capacity NFPC) za novu mjeru efikasnosti. NFPC ima dobru korelaciju s volumenom preko:

$$
\mathrm{NFPC}=9.36 \cdot 10^{-6}(\text { Volume })+6.04 \cdot 10^{-5}(\text { Volume })^{2}
$$

Ovaj odnos je prikazan na slici 2.15. 


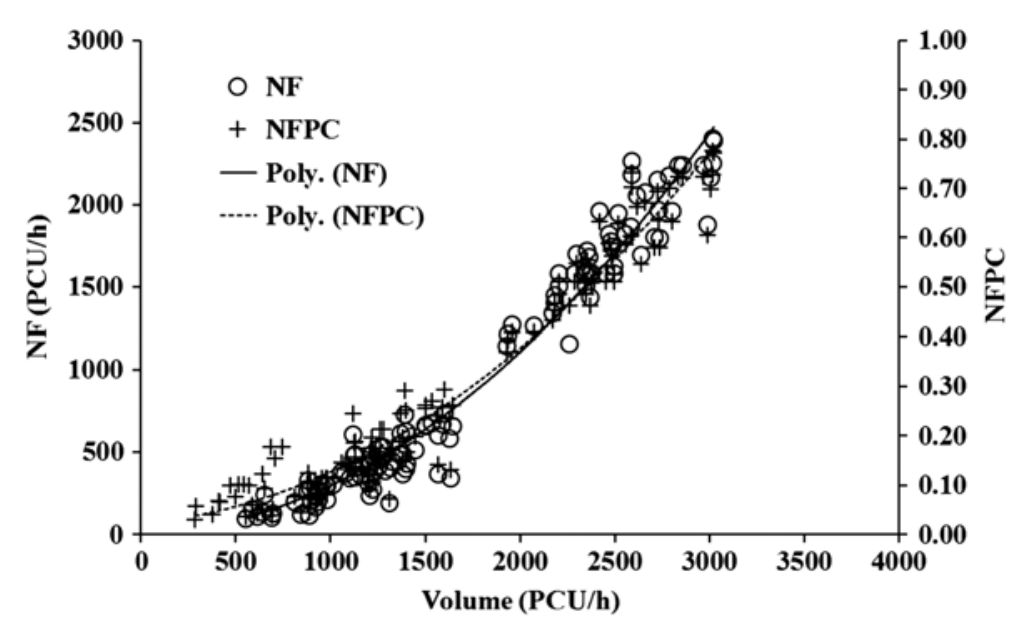

Slika 2.15. Odnos NFPC-a i NF-a za različita prometna opterećenja [P.5]

PF i NFPC su pokazali dobru korelaciju u svim analizama i predložen je matematički odnos prema (slika 2.16):

$$
\mathrm{PF}=92.817(\mathrm{NFPC})^{0.5229}
$$

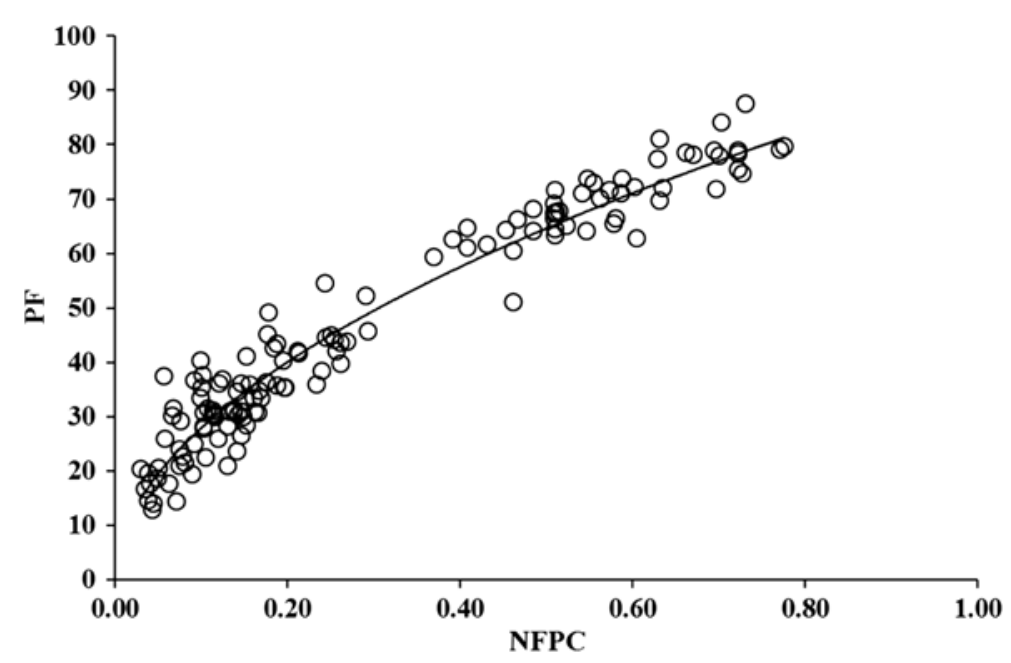

Slika 2.16. Odnos NFPC-a i NF-a [P.5]

$\mathrm{Na}$ kraju su predložene vrijednosti koje mogu poslužiti za određivanje razine usluge i prikazane su u tablici 2.17 .

Tablica 2.17. Predložene vrijednosti NFPC-a za određivanje RU [P.5]

\begin{tabular}{|c|c|c|}
\hline LOS & PTSF (HCM 2010) & $\begin{array}{c}\text { NFPC for mixed } \\
\text { traffic }\end{array}$ \\
\hline A & $\leq 35$ & $\leq 0.15$ \\
B & $>35-50$ & $>0.15-0.31$ \\
C & $>50-65$ & $>0.31-0.51$ \\
D & $>65-80$ & $>0.51-0.75$ \\
E & $>80$ & $>0.75$ \\
\hline
\end{tabular}


Moreno i drugi (2016) [M.2] su nakon kalibracije TWOPASS-a analizirali utjecaj pretjecanja na ATS i PTSF španjolskih cesta.. I ATS i PTSF se (kao i prema HCM-u) definiraju kao zbroj baznog PTSF-a (BPTSF) i utjecaja zona bez pretjecanja:

$$
\begin{gathered}
\operatorname{ATS}=\operatorname{ATS}_{\text {base }}+\operatorname{ATS}_{\mathrm{npz}} \\
\text { ATS }_{\text {base }}=89.52-0.01504 \cdot \mathrm{V}_{\mathrm{d}}-0.0064 \cdot \mathrm{V}_{\mathrm{o}}-0.0522 \cdot \mathrm{HV}_{\mathrm{d}}
\end{gathered}
$$

$\operatorname{ATS}_{\mathrm{npz}}=-2.06-0.0166 \cdot \mathrm{V}_{\mathrm{d}}-0.064 \mathrm{P}_{\mathrm{npz}}+0.027 \cdot \mathrm{HV}_{\mathrm{d}}+2.92 \cdot 10^{-5} \cdot \mathrm{V}_{\mathrm{d}}^{2}-1.45 \cdot 10^{-8} \cdot \mathrm{V}_{\mathrm{d}}{ }^{3}+$ $5.43 \cdot 10^{-5} \cdot \mathrm{P}_{\mathrm{npz}} \cdot \mathrm{V}_{\mathrm{o}}$

$$
\begin{aligned}
\text { PTSF } & =\text { PTSF }_{\text {base }}+\text { PTSF }_{\text {npz }} \\
\text { PTSF }_{\text {base }} & =100 \cdot\left(1-\exp \left(a \cdot \mathrm{V}_{d}{ }^{b}\right)\right.
\end{aligned}
$$

Koeficijenti a i b se dobiju:

$$
\begin{gathered}
\mathrm{a}=-2.12 \cdot 10^{-3}-3.48 \cdot 10^{-5} \cdot \mathrm{V}_{\mathrm{o}}+6.15 \cdot 10^{-4} \cdot \ln \left(\mathrm{V}_{\mathrm{o}}\right) \\
\mathrm{b}=1.33-2.23 \cdot 10^{-5} \cdot \mathrm{V}_{\mathrm{o}}-0.1 \cdot \ln \left(\mathrm{V}_{\mathrm{o}}\right) \\
\mathrm{PTSF}_{\mathrm{npz}}=\frac{-26.86+0.122 \cdot \mathrm{V}_{\mathrm{d}}+0.573 \cdot \mathrm{P}_{\mathrm{npz}}-0.025 \cdot \mathrm{V}_{\mathrm{o}}}{1+\exp \left(0.0025 \cdot \mathrm{V}_{\mathrm{d}}+0.0106 \cdot \mathrm{P}_{\mathrm{npz}}+0.0037 \cdot \mathrm{V}_{\mathrm{o}}\right)}
\end{gathered}
$$

Ono što je novo u njihovom pristupu jest da se analizirala i duljina zona za pretjecanje, a ne samo ukupni postotak (za $0 \%, 50 \%$ i $100 \%$ zona bez pretjecanja). Na slici 2.17 prikazane su analizirane duljine i raspored dionica.

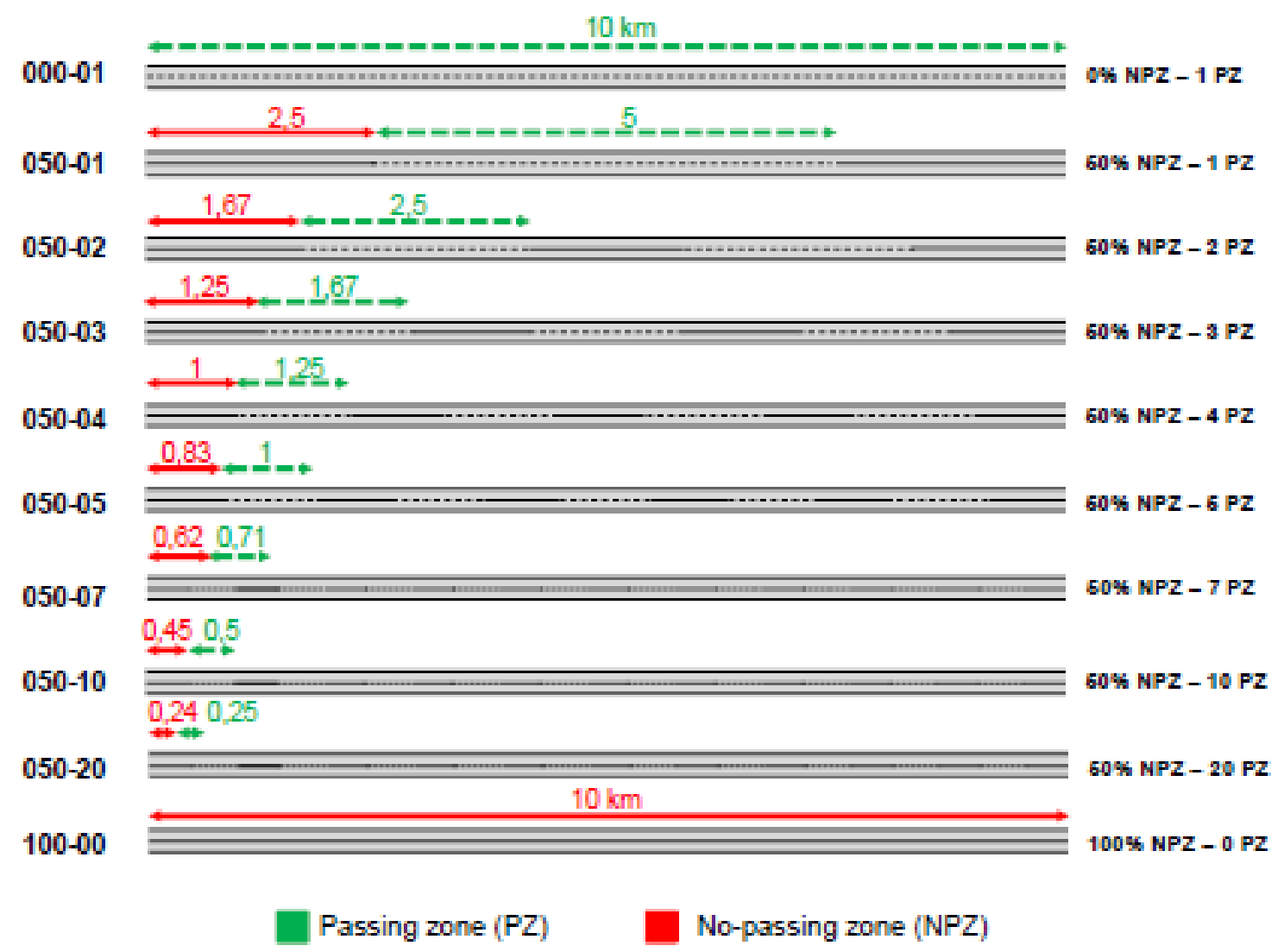

Slika 2.17. Analizirane duljine i raspored zona za pretjecanje [M.2] 
Tako se na osnovne izraze dodaje još i utjecaj duljine pretjecajne zone i dobije se:

$$
\begin{gathered}
\mathrm{PTSF}=\mathrm{PTSF}_{\mathrm{base}}+\mathrm{PTSF}_{\mathrm{npz}}+\mathrm{PTSF}_{\mathrm{pzl}} \\
\mathrm{ATS}=\mathrm{ATS}_{\text {base }}+\mathrm{ATS}_{\mathrm{npz}}+\mathrm{ATS}_{\mathrm{pzl}}
\end{gathered}
$$

Gdje su:

- $\quad$ PTSF $_{\mathrm{pzl}}=$ korekcijski faktor za prosječnu duljinu pretjecajne duljine za PTSF (\%)

- $\quad \mathrm{ATS}_{\mathrm{pzl}}=$ korekcijski faktor za prosječnu duljinu pretjecajne duljine za ATS $(\mathrm{km} / \mathrm{h})$

Vrijednosti korekcijskog faktora utjecaja duljina zona za pretjecanje prikazani su u tablici 2.18 .

\begin{tabular}{|c|c|c|c|c|c|c|c|c|c|}
\hline \multicolumn{10}{|c|}{ Average passing zone length $(\mathrm{m})$} \\
\hline $\begin{array}{l}\text { Directional } \\
\text { split }\end{array}$ & $\begin{array}{l}\text { Directional } \\
\text { traffic flow } \\
\text { rate (veh/h) }\end{array}$ & 250 & 500 & 714 & 1000 & 1250 & 1670 & 2500 & 5000 \\
\hline \multirow{3}{*}{$20 / 80$} & $<200$ & 5.37 & 2.22 & 3.91 & 1.69 & 1.41 & 0.9 & 0.21 & 0.00 \\
\hline & 400 & -0.36 & -2.28 & -0.14 & -2.22 & -1.97 & -2.23 & -2.11 & 0.00 \\
\hline & $>600$ & -5.1 & 2.77 & 1.71 & 1.69 & 1.41 & -0.01 & -2.09 & 0.00 \\
\hline \multirow{4}{*}{$30 / 70$} & $<200$ & 10.83 & 6.75 & 6.98 & 3.71 & 2.7 & 1.96 & 1.42 & 0.00 \\
\hline & 400 & 2.65 & 0.43 & 2.04 & 0.05 & -0.11 & -0.02 & -0.27 & 0.00 \\
\hline & 600 & 0.4 & -0.78 & 0.5 & -1.05 & -0.9 & -0.95 & -0.65 & 0.00 \\
\hline & $>800$ & -0.73 & -2.22 & -0.74 & -1.99 & -2.56 & -2.18 & -2.54 & 0.00 \\
\hline \multirow{6}{*}{$40 / 60$} & $<200$ & 14.65 & 10.46 & 9.08 & 5.03 & 3.75 & 2.26 & 1.83 & 0.00 \\
\hline & 400 & 6.06 & 3.41 & 4.11 & 1.4 & 1.59 & 1.27 & 0.73 & 0.00 \\
\hline & 600 & 2.2 & 0.39 & 1.47 & -0.02 & -0.14 & -0.44 & -0.57 & 0.00 \\
\hline & 800 & 1.24 & -0.09 & 0.97 & 0.08 & -0.19 & -0.11 & -0.34 & 0.00 \\
\hline & 1000 & 0.86 & 0.34 & 0.68 & 0.24 & 0.21 & 0.15 & 0.18 & 0.00 \\
\hline & $>1,200$ & -0.29 & -0.65 & -0.23 & -0.36 & -0.63 & -0.24 & -0.23 & 0.00 \\
\hline \multirow{7}{*}{$50 / 50$} & $<200$ & 18.14 & 12.97 & 10.02 & 6.12 & 3.91 & 2.29 & 1.39 & 0.00 \\
\hline & 400 & 9.29 & 6.67 & 5.69 & 2.49 & 1.77 & 1.37 & 0.54 & 0.00 \\
\hline & 600 & 4.44 & 1.86 & 2.6 & 0.89 & 0.23 & -0.12 & -0.58 & 0.00 \\
\hline & 800 & 2.43 & 0.97 & 1.49 & 0.14 & 0.08 & -0.18 & -0.56 & 0.00 \\
\hline & 1000 & 1.49 & 0.72 & 1.21 & 0.43 & 0.24 & 0.36 & 0.33 & 0.00 \\
\hline & 1200 & 1.49 & 1.34 & 1.47 & 1.31 & 1.22 & 1.25 & 1.28 & 0.00 \\
\hline & $>1400$ & 2.45 & 2.66 & 2.31 & 2.33 & 2.25 & 2.59 & 2.81 & 0.00 \\
\hline \multirow{7}{*}{$60 / 40$} & $<200$ & 21.54 & 16.07 & 12.15 & 6.26 & 3.59 & 1.69 & 1.29 & 0.00 \\
\hline & 400 & 12.02 & 9.22 & 7.42 & 3.77 & 2.83 & 1.02 & 0.13 & 0.00 \\
\hline & 600 & 6.7 & 4.19 & 4.03 & 1.12 & 0.26 & -0.31 & -1.35 & 0.00 \\
\hline & 800 & 4.2 & 2.35 & 2.26 & 0.68 & 0.26 & -0.46 & -0.64 & 0.00 \\
\hline & 1000 & 2.73 & 1.69 & 1.96 & 1.11 & 0.48 & 0.44 & 0.17 & 0.00 \\
\hline & 1200 & 2.15 & 1.85 & 1.81 & 1.59 & 1.54 & 1.36 & 1.31 & 0.00 \\
\hline & $>1,400$ & 2.42 & 2.48 & 2.7 & 2.61 & 2.28 & 2.49 & 2.43 & 0.00 \\
\hline
\end{tabular}

Tablica 2.18. Korekcijski faktor utjecaja duljina zona za pretjecanje na PTSF [M.2] 


\begin{tabular}{|c|c|c|c|c|c|c|c|c|c|}
\hline \multirow{7}{*}{$70 / 30$} & $<200$ & 24.14 & 18.82 & 12.95 & 5.76 & 2.88 & 1.13 & 0.29 & 0.00 \\
\hline & 400 & 16.23 & 12.56 & 10.24 & 4.49 & 2.77 & 0.84 & 0.49 & 0.00 \\
\hline & 600 & 9.15 & 6.24 & 5.47 & 1.96 & 0.69 & -0.61 & -1.14 & 0.00 \\
\hline & 800 & 6.33 & 4.2 & 3.72 & 1.28 & 0.34 & -0.47 & -1.11 & 0.00 \\
\hline & 1000 & 4.66 & 3.46 & 2.93 & 1.6 & 1.07 & 0.62 & 0.46 & 0.00 \\
\hline & 1200 & 3.38 & 2.92 & 2.74 & 2.25 & 2.06 & 1.83 & 1.55 & 0.00 \\
\hline & $>1400$ & 3.42 & 3.64 & 3.56 & 3.24 & 3.22 & 2.6 & 3.07 & 0.00 \\
\hline \multirow{7}{*}{$80 / 20$} & $<200$ & 26.89 & 21.55 & 14.22 & 5.52 & 1.84 & -0.19 & -0.32 & 0.00 \\
\hline & 400 & 21.14 & 17.41 & 12.67 & 6.26 & 3.43 & 2.07 & 0.34 & 0.00 \\
\hline & 600 & 13.93 & 10.89 & 8.35 & 3.89 & 1.76 & 0.05 & -0.96 & 0.00 \\
\hline & 800 & 9.93 & 7.83 & 5.92 & 2.86 & 0.93 & 0.2 & -0.55 & 0.00 \\
\hline & 1000 & 7.52 & 6.22 & 4.87 & 3.04 & 2.22 & 1.11 & 0.73 & 0.00 \\
\hline & 1200 & 5.54 & 5.13 & 4.47 & 3.64 & 3.25 & 2.67 & 2.26 & 0.00 \\
\hline & $>1400$ & 6.3 & 5.56 & 4.93 & 3.99 & 3.03 & 2.95 & 2.36 & 0.00 \\
\hline
\end{tabular}

Iz tablice 2.18 može se vidjeti da zona duljine 5000 m predstavlja „,bazne“ uvjete jer nema korekcija PTSF-a. Smanjenjem duljine zone pretjecanja smanjuje se korekcijski faktor te time i njezin utjecaj na PTSF. Time se nadopunjuje HCM model još jednim bitnim parametrom. Na kraju se predlaže da se u sljedećem izdanju HCM-a kvantificira ne samo ukupni postotak zona bez pretjecanja, nego i duljina pojedinih zona. Utjecaj duljine zona za pretjecanje na PTSF je potvrđen i u kasnijim istraživanjima [M.3, M.4].

U uvodnom poglavlju su već spomenuti problemi primjene HCM-a i drugih modela za BiH uvjete (uvjete u regiji). Osim neprilagođenosti prevladavajućim lokalnim prometnim uvjetima, problem predstavljaju i drugačiji pristupi (kompleksnost) koji su teško primjenjivi za BiH prilike.

Istraživanja na temu RU dvotračnih izvangradskih cesta se općenito mogu podijeliti na dva pristupa, jedan koji nastoji uvesti nove mjere efikasnosti koje bi zamijenile PTSF, te drugi korištenjem PTSF-a koji je tema ovog rada.

Jedan dio istraživanja iz drugog pristupa usmjeren je na pokušaj boljeg definiranja PTSF-a nego je to slučaj preko vremena slijeda $3 \mathrm{~s}$ (analizirajući vjerojatnosti kolona).

Drugi dio istraživanja je usmjeren na izradu modela PTSF-a preko $3 \mathrm{~s}$, bilo uvođenjem novih parametara i zakonitosti ili samo prilagodbom na lokalne uvjete.

S obzirom na istraživanje i rezultate ovog rada, posebno se može se izdvojiti španjolsko istraživanje [M.2] i uvođenje $u$ analizu parametra duljine zona pretjecanja.

Primjenjivost drugih modela u regiji dodatno je analizirana u poglavlju 4 zajedno s analizom rezultata dobivenih na temelju provedenih terenskih istraživanja. 


\section{METODOLOGIJA TERENSKIH ISTRAŽIVANJA DVOTRAČNIH IZVANGRADSKIH CESTA}

U ovom poglavlju je predstavljena metodologija provedenih terenskih istraživanja na dvotračnim izvangradskim cestama na području Hercegovine. Mreža dvotračnih cesta dijeli se na lokalne, regionalne i magistralne (u Hrvatskoj su to državne) ceste. S obzirom na kategorizaciju (značaj, duljine, prometno opterećenje i brzine), magistralne ceste su najvažnije. Dopuštena brzina na ovim cestama je $80 \mathrm{~km} / \mathrm{h}$ i imaju veću homogenost od lokalnih i regionalnih.

Istraživanja su provedena na magistralnim cestama, a kao reprezentativne su odabrane dionice magistrale M17 koja predstavlja europski koridor E73 i pruža se duž cijele države. Dionica Salakovac - Grabovica (duljine 19700 m) je istraživana za potrebe kalibracije i izrade modela, dok je dionica Buna - Čapljina korištena za verifikaciju modela. Za snimanja su korištena prenosiva automatska brojila i video kamere.

Brojila su vršila klasifikaciju vozila i registrirala su vrijeme prolaska pojedinačnog vozila što je omogućilo određivanje PTSF-a. Video snimka omogućuje kontrolu brojila i daje uvid u parametre ponašanje vozača. S obzirom da je PTSF veličina koja definira slobodu manevra vozača, mikroskopski se pristupilo problemu na način da su se definirale katakteristike pojedinih parametara toka mjerenjem u presjecima brzine i vremena slijeda svakog pojedinog vozila.

Snimanja su najvećim dijelom provedena tijekom proljeća i ljeta (travanj - kolovoz) jer je to razdoblje godine kad je promet znatno veći od ostatka godine (osobito srpanj i kolovoz zbog turističke sezone. Na svakom od 7 glavnih presjeka provedena su snimanja u ukupnom trajanju oko 4 tjedna (u 2 ili 3 navrata snimano neprekidno jedan ili dva tjedna). U analize je uzeto razdoblje dana od 06:00 sati ujutro do 22:00 uvečer iz razloga što je promet u ostatku dana zanemariv. Iz analize su izostavljena i satna opterećenja analiziranog smjera koja su manja od $100 \mathrm{voz} / \mathrm{h}$ iz razloga što takva opterećenja ne daju konzistentne rezultate PTSF-a. Analizirana su 15-minutna opterećenja (pretvorena u satna) što je, uz odbacivanje ekstrema (ekstremne vrijednosti PTSF-a) i uz probleme rada brojila, dalo preko 1300 satnih opterećenja. Zbog problema rada brojila na presjecima 4 i 7 taj broj je nešto manji (700 sati).

Provedena su i dodatna snimanja, u trajanju 7 dana (oko 400 satnih opterećenja po presjeku), s ciljem boljeg definiranja utjecaja zona za pretjecanje duljina $450 \mathrm{~m}$.

$\mathrm{Na}$ temelju vremena prolaska svakog pojedinog vozila po smjeru (na pojedinom presjeku) dobila su se vremena slijeda vozila. Ako je vrijeme slijeda vozila manje od 3 sekunde, vozilo je u koloni. Brojčani odnos vozila koja su u koloni i ukupnog broja vozila predstavlja PTSF u pojedinom presjeku, a prosječna vrijednost presjeka daje PTSF dionice za analizirani smjer. 


\subsection{Korištena oprema}

Za snimanje spomenutih prometnih parametara korišteno je 5 prenosivih brojila MetroCount 5600 (slike 3.1 i 3.2) i radarsko brojilo EasyCOUNT (slika 3.3).

Brojila MetroCount se sastoje od dva gumena crijeva (razmak $1.0-2.5 \mathrm{~m}$ ) i uređaja koji registrira, analizira i pohranjuje podatke. Na osnovu tlaka kotača vozila na crijeva, uređaj brojila izvrši klasifikaciju, te zabilježi brzinu i vrijeme prolaska vozila. Crijeva brojila su postavljana na razmaku $2.5 \mathrm{~m}$ jer se na većim razmacima dobije preciznije mjerenje brzine.

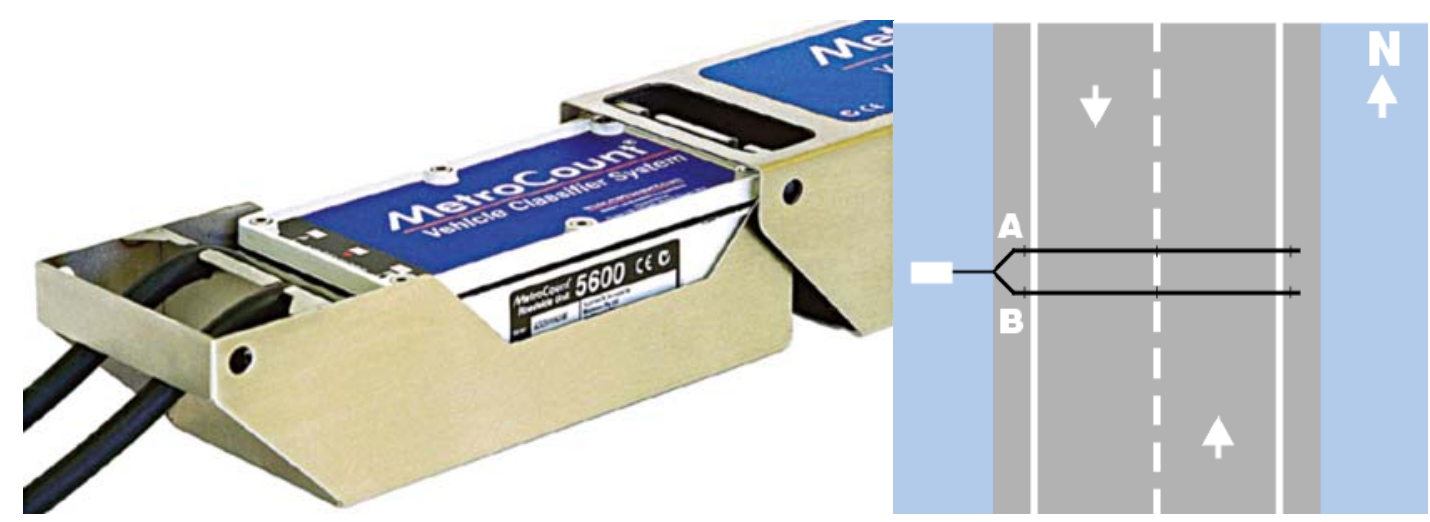

Slika 3.1. Slika brojila MetroCount 5600 i shematski prikaz postavljanja [W.1]

Korištena je ARX klasifikacija [W.2] (tablica 3.1) koja najbolje odgovara voznom parku (od ponuđenih u softwareu za obradu podataka) u BiH. Ova klasifikacija predstavlja modifikaciju australske klasifikacije AustRoads94 [W.2].

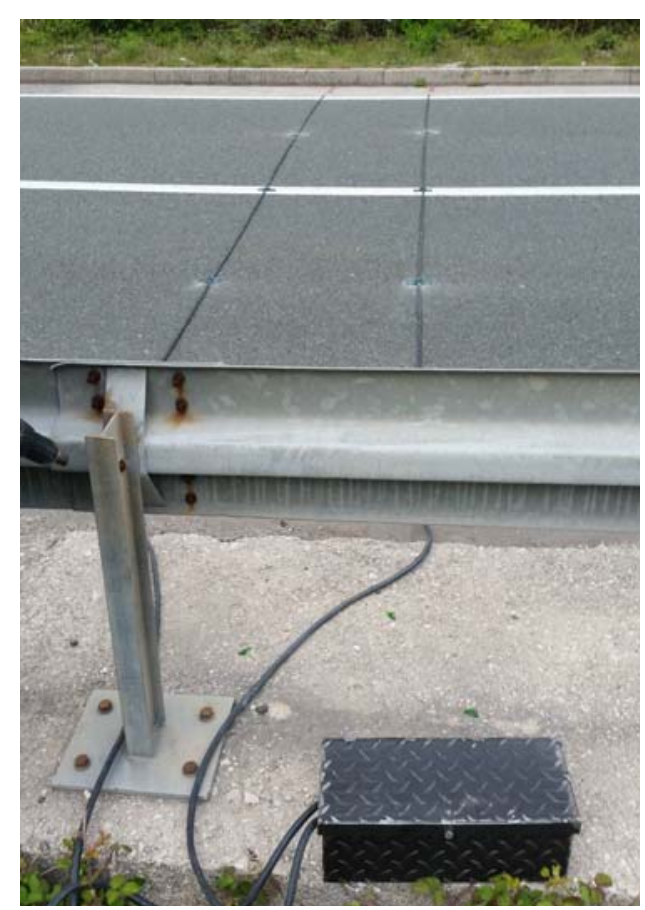

Slika 3.2. Način postavljanja brojila MetroCount 5600 
Ovakav tip brojila daje vrlo dobre i pouzdane rezultate, kao i jednostavnu mogućnost obrade. Probleme predstavljaju način njihovog postavljanja preko kolnika (slika 3.2) jer je potreban veliki broj učvršćivanja vijcima, sigurnost postavljanja, a i trajnost jer za veća opterećenja i brzine dolazi do oštećenja gumenih crijeva.

Tablica 3.1. ARX klasifikacija vozila [W.2]

\begin{tabular}{|c|c|c|c|c|c|c|c|}
\hline Axles & Groups & Description & \multicolumn{2}{|c|}{ Class } & Parameters & $\begin{array}{l}\text { Dominant } \\
\text { Vehicle }\end{array}$ & Aggregate \\
\hline 2 & 1 or 2 & $\begin{array}{l}\text { Very Short - Bicycle or } \\
\text { Motorcycle }\end{array}$ & $\mathrm{MC}$ & 1 & $\mathrm{~d}(1)<1.7 \mathrm{~m} \&$ axles $=2$ & $\Leftrightarrow$ & \multirow{3}{*}{1 (Light) } \\
\hline 2 & 1 or 2 & $\begin{array}{l}\text { Short - Sedan, Wagon, } \\
\text { 4WD, Utility, Light Van }\end{array}$ & SV & 2 & $\begin{array}{c}\mathrm{d}(1)>=1.7 \mathrm{~m}, \mathrm{~d}(1)<=3.2 \mathrm{~m} \mathrm{\&} \\
\text { axles }=2\end{array}$ & $\underset{0}{0}$ & \\
\hline $\begin{array}{l}3,4 \\
\text { or } 5\end{array}$ & 3 & $\begin{array}{l}\text { Short Towing - Trailer, } \\
\text { Caravan, Boat, etc. }\end{array}$ & SVT & 3 & $\begin{array}{c}\text { groups }=3, \mathrm{~d}(1)>=2.1 \mathrm{~m}, \\
\mathrm{~d}(1)<=3.2 \mathrm{~m}, \mathrm{~d}(2)>=2.1 \mathrm{~m} \& \\
\text { axles }=3,4,5\end{array}$ & $\Leftrightarrow$ & \\
\hline 2 & 2 & Two axle truck or Bus & TB2 & 4 & $\mathrm{~d}(1)>3.2 \mathrm{~m} \&$ axles $=2$ & बत्] & \multirow{3}{*}{2 (Medium) } \\
\hline 3 & 2 & Three axle truck or Bus & TB3 & 5 & axles $=3 \&$ groups $=2$ & 叶 & \\
\hline$>3$ & 2 & Four axle truck & T4 & 6 & axles $>3 \&$ groups $=2$ & 的星 & \\
\hline 3 & 3 & $\begin{array}{c}\text { Three axle articulated } \\
\text { vehicle or Rigid vehicle } \\
\text { and trailer }\end{array}$ & ART3 & 7 & $\begin{array}{c}\mathrm{d}(1)>3.2 \mathrm{~m}, \text { axles }=3 \& \\
\text { groups }=3\end{array}$ & 男 & \multirow{6}{*}{3 (Heavy) } \\
\hline 4 & $>2$ & $\begin{array}{c}\text { Four axle articulated } \\
\text { vehicle or Rigid vehicle } \\
\text { and trailer }\end{array}$ & ART4 & 8 & $\begin{array}{c}\mathrm{d}(2)<2.1 \mathrm{~m} \text { or } \mathrm{d}(1)<2.1 \mathrm{~m} \text { or } \\
\mathrm{d}(1)>3.2 \mathrm{~m} \\
\text { axles }=4 \& \text { groups }>2\end{array}$ & 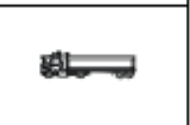 & \\
\hline 5 & $>2$ & $\begin{array}{c}\text { Five axle articulated } \\
\text { vehicle or Rigid vehicle } \\
\text { and trailer }\end{array}$ & ART5 & 9 & $\begin{array}{c}\mathrm{d}(2)<2.1 \mathrm{~m} \text { or } \mathrm{d}(1)<2.1 \mathrm{~m} \text { or } \\
\mathrm{d}(1)>3.2 \mathrm{~m} \\
\text { axles }=5 \& \text { groups }>2\end{array}$ & 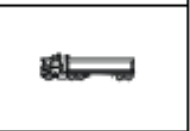 & \\
\hline$>=6$ & $>2$ & $\begin{array}{c}\text { Six (or more) axle } \\
\text { articulated vehicle or Rigid } \\
\text { vehicle and trailer }\end{array}$ & ART6 & 10 & $\begin{array}{c}\text { axles }=6 \& \text { groups }>2 \text { or } \\
\text { axles }>6 \text { \& groups }=3\end{array}$ & 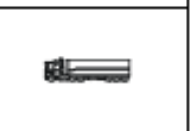 & \\
\hline$>6$ & 4 & $\begin{array}{l}\text { B-Double or Heavy truck } \\
\text { and trailer }\end{array}$ & $\mathrm{BD}$ & 11 & groups $=4 \&$ axles $>6$ & 和 & \\
\hline$>6$ & $>=5$ & $\begin{array}{l}\text { Double or triple road train } \\
\text { or Heavy truck and two (or } \\
\text { more) trailers }\end{array}$ & DRT & 12 & groups $>=5 \&$ axles $>6$ & 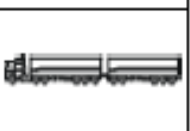 & \\
\hline
\end{tabular}

S druge strane radarsko brojilo (slika 3.3) ima jednostavnost postavljanja (obično na stup prometnog znaka), ali je ovo brojilo bilo dostupno tek pred kraj istraživanja te je bilo mnogo manje korišteno od MetroCount brojila.

Kao što je prethodno spomenuto, rezultati snimanja su vrijeme prolaska svakog pojedinog vozila po smjeru, brzina i klasifikacija vozila. Na taj način se mogu, nakon obrade, dobiti podaci neophodni za određivanje PTSF-a, kao i za kalibraciju simulacijskog softwarea (brzina, vrijeme slijeda, itd.) što je detaljnije opisano u poglavljima 4 i 5. 


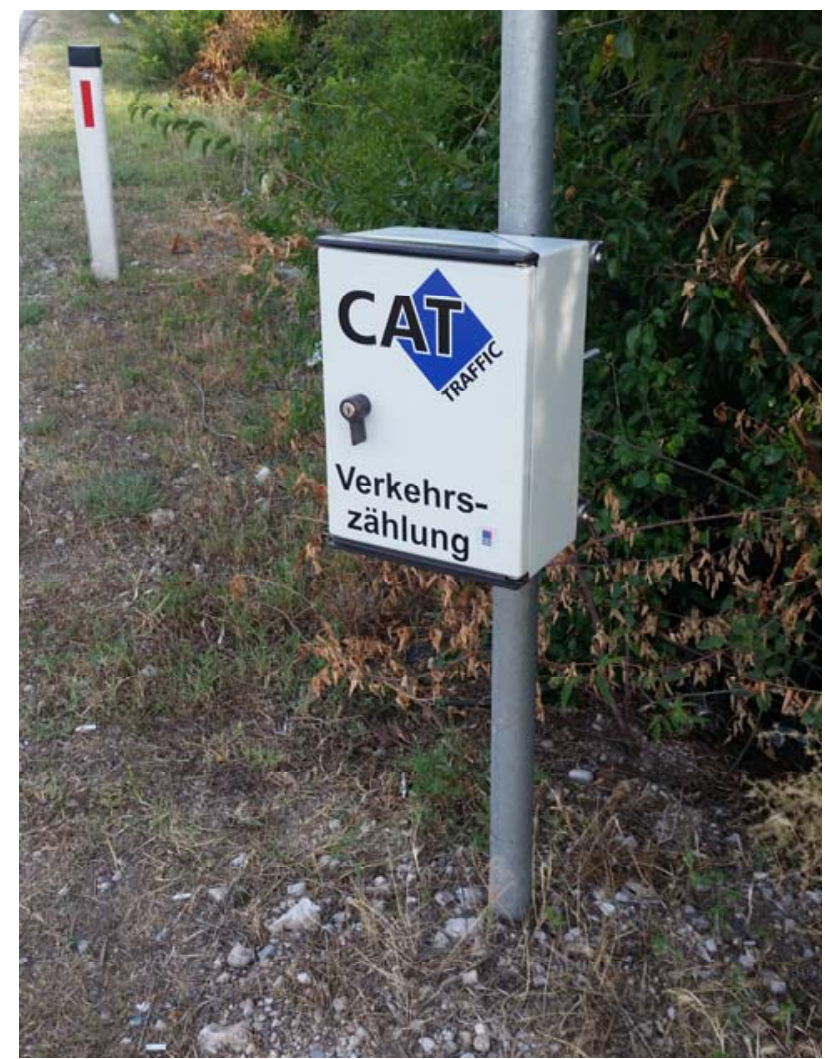

Slika 3.3. Radarsko brojilo EasyCOUNT

U istraživanju su još korištene i videokamere (slika 3.4) koje su ponajprije imale funkciju kontrole brojila u smislu broja vozila i klasifikacije. Videosnimke su također bile korisne za spoznavanje ponašanja vozača, ponajprije u manevrima pretjecanja (provjera broja i trajanja pretjecanja u usporedbi sa simulacijama).

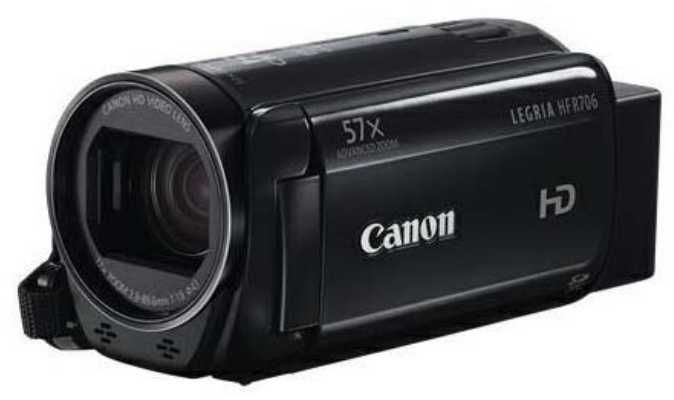

Slika 3.4. Video kamere korištene za snimanje

\subsection{Karakteristike analiziranih dionica}

Odabrane dionice imaju relativno dobru geometriju (homogenost dionice) i za BiH prilike značajno opterećenje (PGDP oko 7000 voz/dan i PLDP oko 10000 voz/dan). Značajno je i to što su to daljinske dionice koje povezuju jug i sjever države (također i susjednu Republiku 
Hrvatsku). Time se dobije i značajan uzorak karakteristika vozača i voznog parka jer se izbjegava veći lokalni utjecaj.

Analizirana dionica magistralne ceste M 17 Salakovac - Grabovica nalazi se između Mostara i Jablanice. Početak je na 14 km od centra grada Mostara i pruža se do Grabovice (do Hidroelektrane Grabovica) u duljini gotovo $20 \mathrm{~km}$ (slika 3.5). Dionica je izvangradska dvotračna, ujednačene geometrije i prometnog opterećenja i time se može smatrati homogenom dionicom. Postoji nekoliko priključaka na ovu dionicu, ali oni gotovo da ne utječu na odvijanje prometa na glavnoj cesti s obzirom da postoje trakovi za lijeva skretanja i što je promet na priključnim cestama zanemariv. Dionica Buna - Čapljina koja je korištena za verifikaciju (validaciju inače u tekstu) modela opisana je u poglavlju 6.

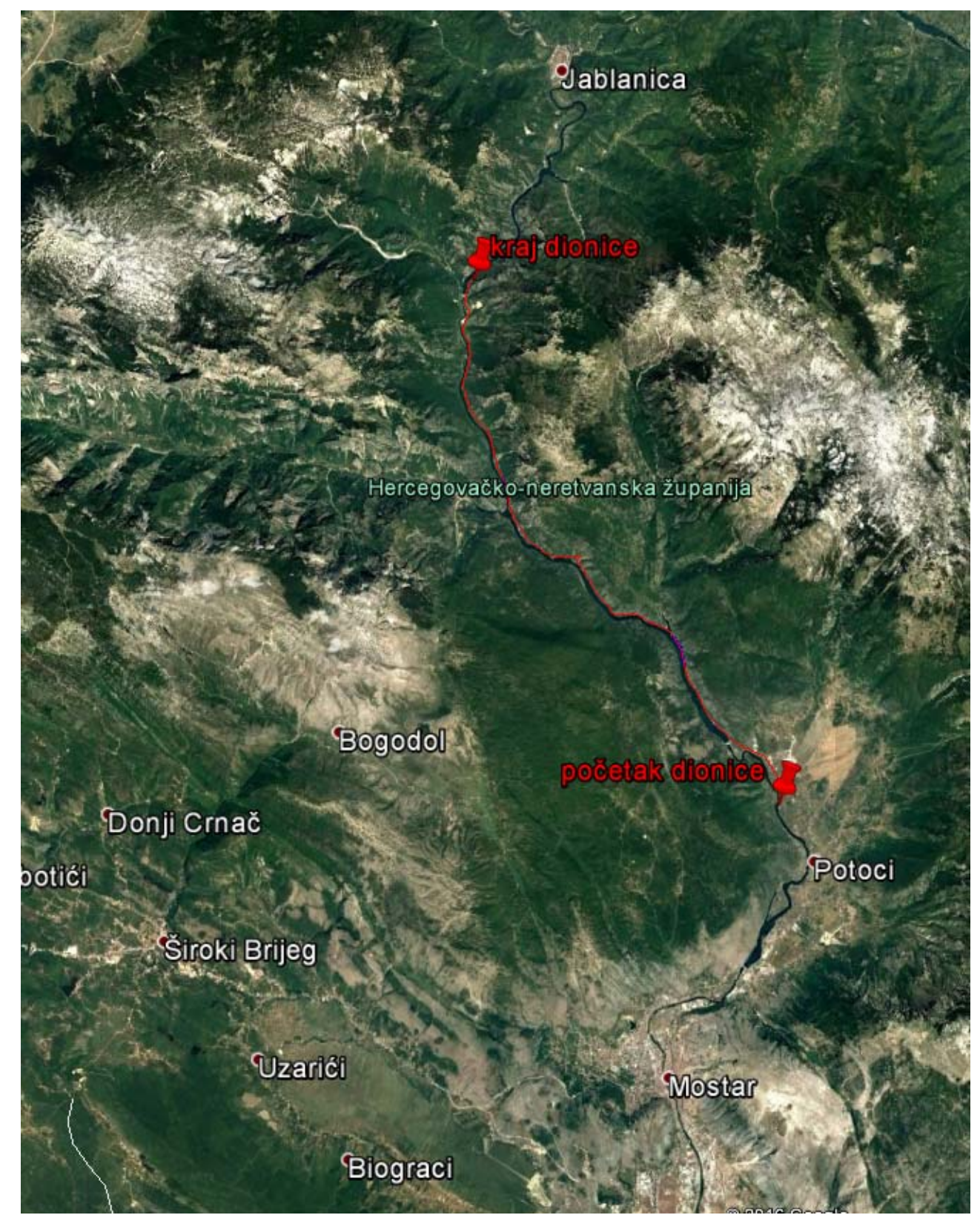

Slika 3.5. Položaj predmetne dionice Salakovac - Grabovica (crvena boja) 
Predmetna dionica Salakovac - Grabovica (slika 3.5) ima sljedeće karakteristike:

- duljina $19700 \mathrm{~m}$

- 65 horizontalnih krivina

- minimalni polumjer horizontalne krivine je $\mathrm{R}_{\min }=230 \mathrm{~m}$, maksimalni $\mathrm{R}_{\max }=1000$ $\mathrm{m}$, a prosječna vrijednost iznosi $460.35 \mathrm{~m}$

- prosječna brzina vožnje iz istraživanja $\mathrm{V}=83.60 \mathrm{~km} / \mathrm{h}$

- uzdužni nagibi $<3 \%$, izuzev kratkih dionica duljine do $300 \mathrm{~m}$

- krivinska karakteristika $71.44^{\circ} / \mathrm{km}$

- ukupno 13 zona za pretjecanje, po jedna duljine $1100 \mathrm{~m}$ i $700 \mathrm{~m}$ te 11 zona duljina $400-450 \mathrm{~m}$

- računska brzina od $80 \mathrm{~km} / \mathrm{h}$.

Predmetna dionica ima vrlo dobre karakteristike za BiH prilike i predstavlja dobar primjer homogene dionice.

Početak dionice u Salakovcu nastavlja se na cestu u naselju (Mostar - Salakovac) gdje su ograničenja brzine 60 i $70 \mathrm{~km} / \mathrm{h}$, dok je sa sjevera ulaz na dionicu nakon izvangradske dionice neujednačene geometrije i brzina $40-50 \mathrm{~km} / \mathrm{h}$.

\subsection{Terenska istraživanja dionice}

Na raspolaganju je bilo 5 prenosivih MetroCount brojila, no za vrijeme istraživanja je „nestalo“ jedno MetroCount brojilo. Kasnije, pred kraj istraživanja, nabavljeno je i radarsko brojilo EasyCount. Ovo je spomenuto iz razloga da se vidi raspoloživa oprema za snimanje koja je diktirala način postavljanja. Za snimanje dionice poželjno je što više brojila kako bi se pokrio što veći broj specifičnih presjeka analizirane dionice (slika 3.6).

Stoga su definirani prioritetni presjeci na kojim je provedena glavnina snimanja, uz dodatne presjeke koji su služili za kontrolu. Definirano je 7 glavnih presjeka i nekoliko pomoćnih.

Najprije su odabrani presjeci 1, 3, 4, 5 i 7 (brojila na slici 3.6) zbog pokrivanja cijele dionice. Ovi presjeci su odabrani planski kako bi se u kombinaciji s budućim snimanjima (presjeci 2 i 6) pokrile specifičnosti dionice u smislu definiranja zona pretjecanja. Naime, presjek 3 nalazi se poslije zone pretjecanja duljine $1100 \mathrm{~m}$ (slika 3.6), a presjek 5 prije zone pretjecanja duljine $700 \mathrm{~m}$ (slika 3.6).

Postavljenjem brojila 2 prije zone pretjecanja duljine $1100 \mathrm{~m}$ i brojila 6 iza zone pretjecanja duljine $700 \mathrm{~m}$ dobili su se potrebni podaci za definiranje utjecaja ovih zona. 


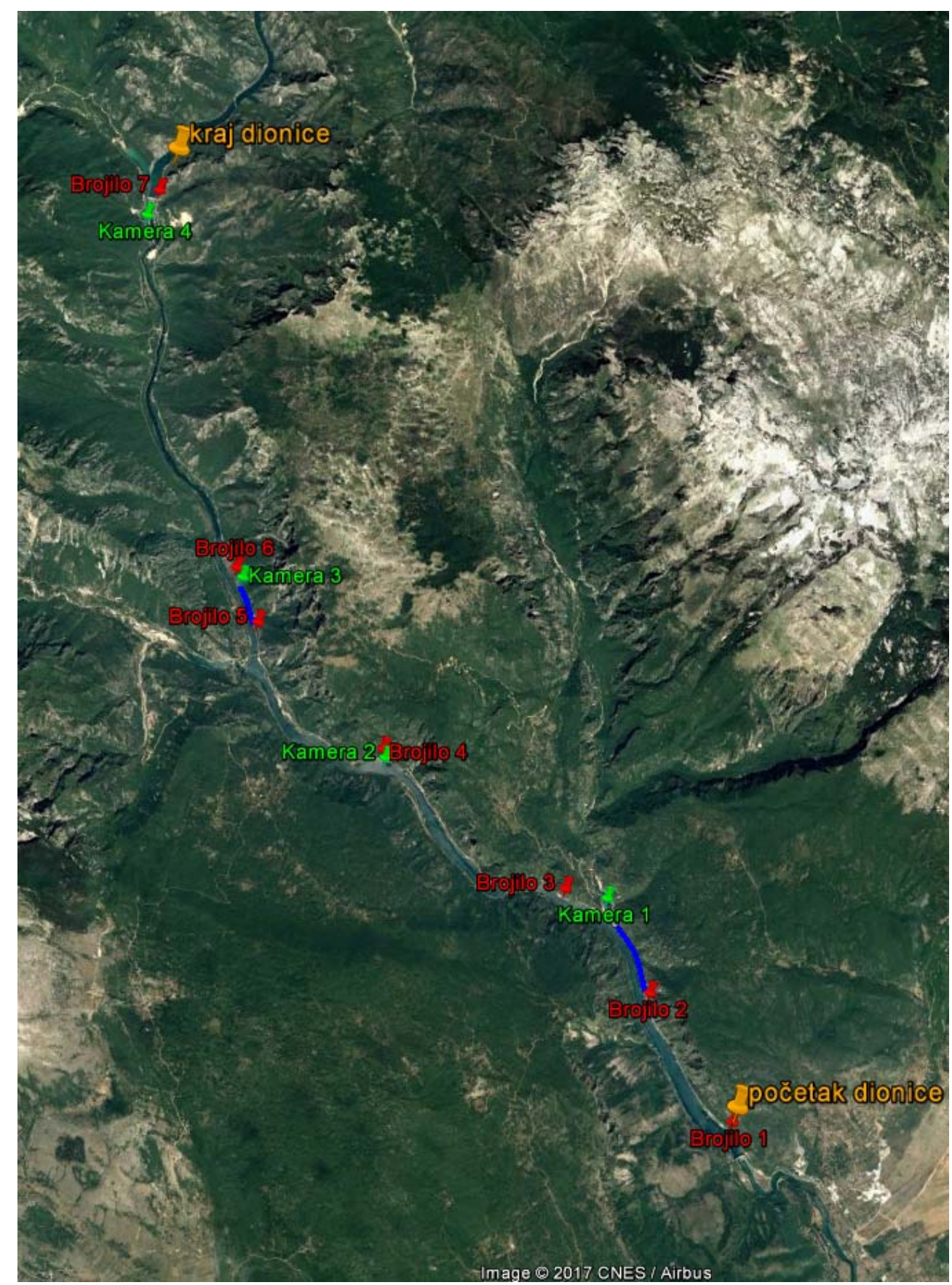

Slika 3.6. Dionica i lokacije (presjeci) snimanja magistralne ceste M 17 Salakovac - Grabovica (Mostar - Sarajevo)

Kao što se može vidjeti sa slike 3.6 dio dionice od presjeka 6 do presjeka 7 nije pokriven mjerenjima kao ostatak dionice. Razlog je taj što postoje samo dvije zone za pretjecanje duljina po $450 \mathrm{~m}$ i nema nekih posebnih specifičnosti.

Presjek 1 na početku je dionice u Salakovcu (stacionaža 0+000) i mjesto postavljanja je prikazano na slici 3.7. Nalazi se iza tunela Salakovac i odmah na početku je zona pretjecanja duljine $450 \mathrm{~m}$. 


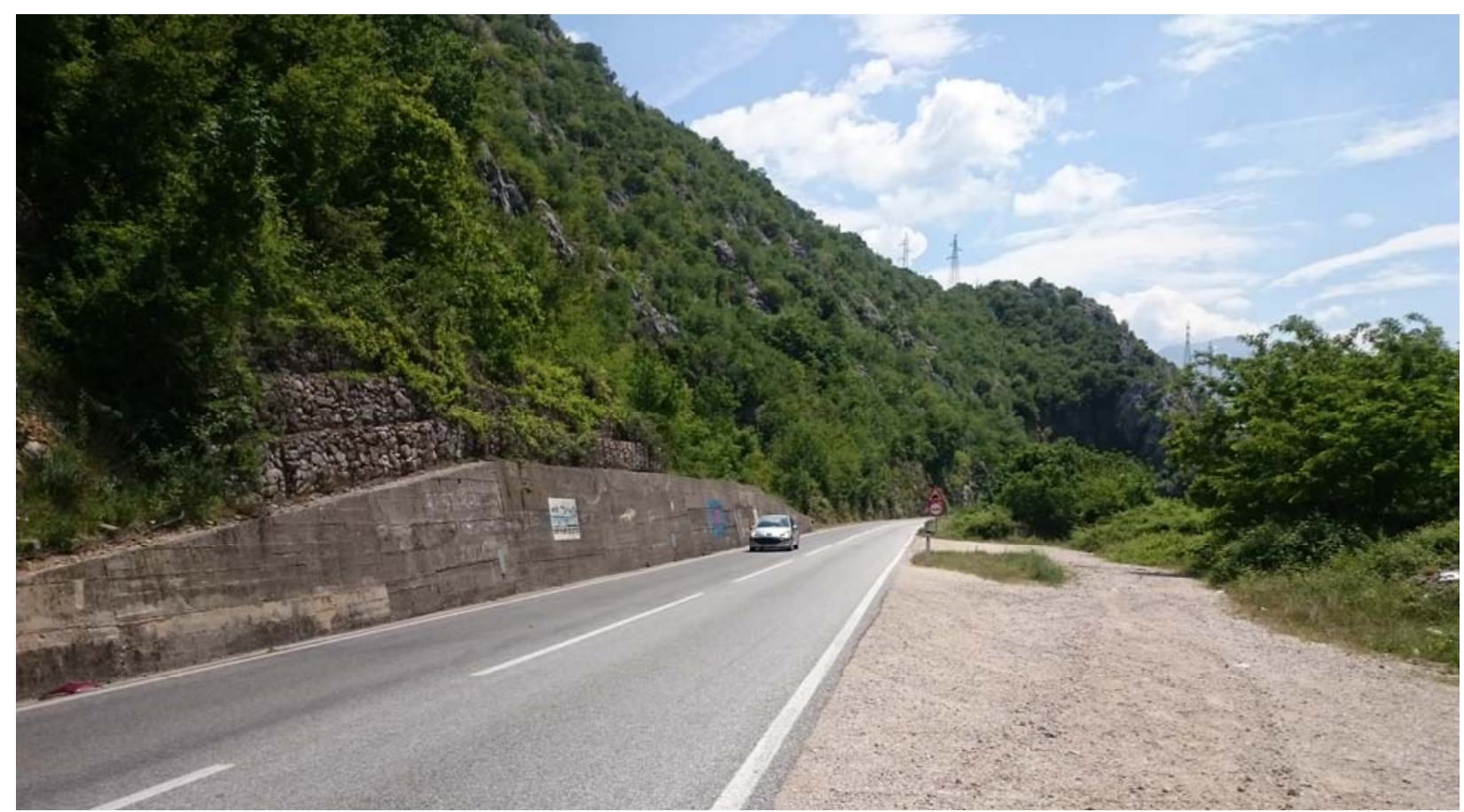

Slika 3.7. Presjek 1 snimanja (ulaz /izlaz u Salakovcu), pogled u smjeru Sarajevo - Mostar

Presjek 3 nalazi se točno na petom kilometru (5+000) i smješten je između 2 kratka tunela, nakon zone pretjecanja (iz smjera Mostara) duljine $1100 \mathrm{~m}$ (slika 3.8).

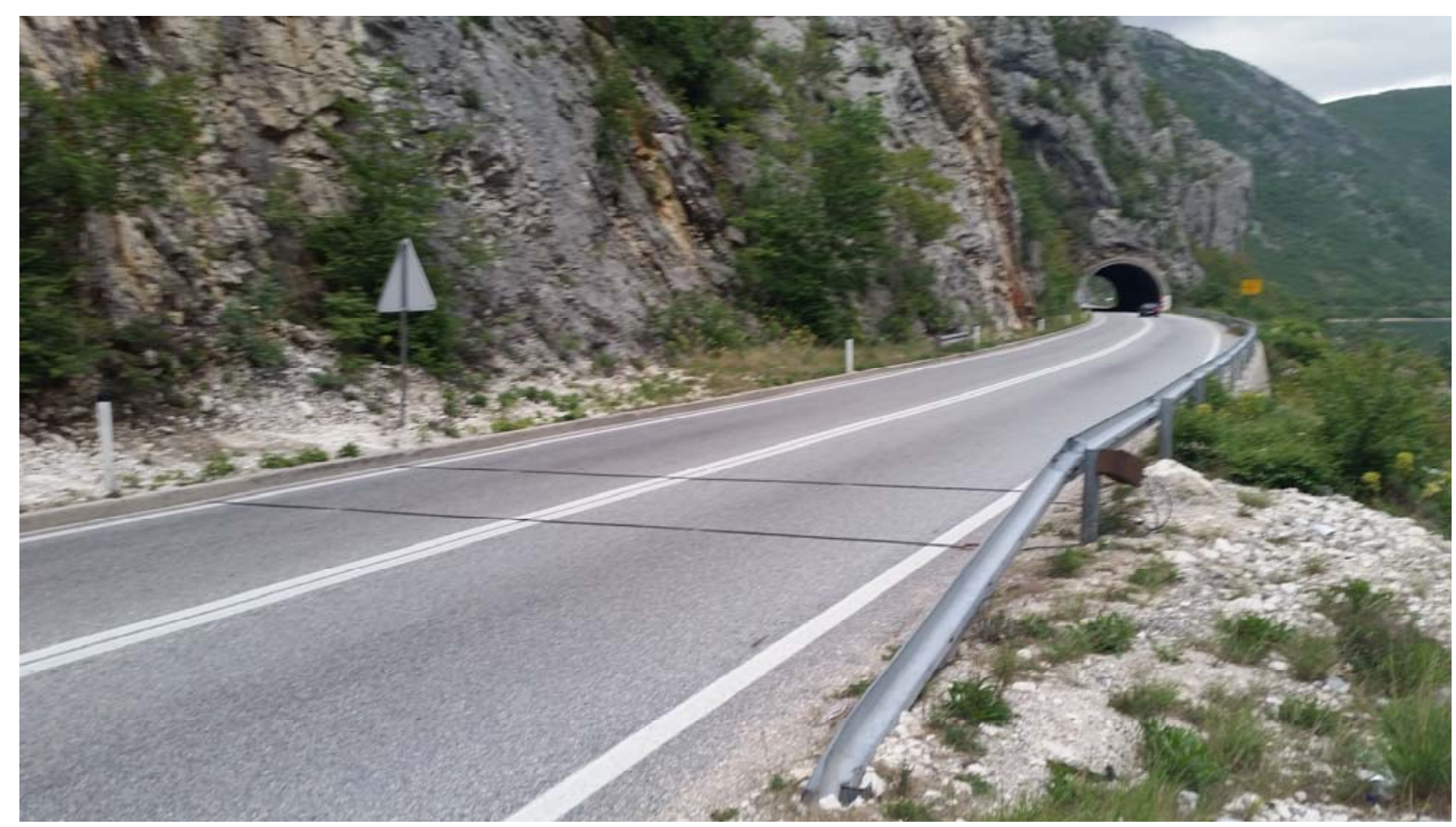

Slika 3.8. Presjek 3 snimanja (poslije zone $1100 \mathrm{~m}$ ), pogled u smjeru Sarajevo - Mostar

Zatim je odabran presjek 4 koji se nalazi približno na polovici dionice $(8+900)$, a na početku zone pretjecanja duljine $450 \mathrm{~m}$ (slika 3.9). 


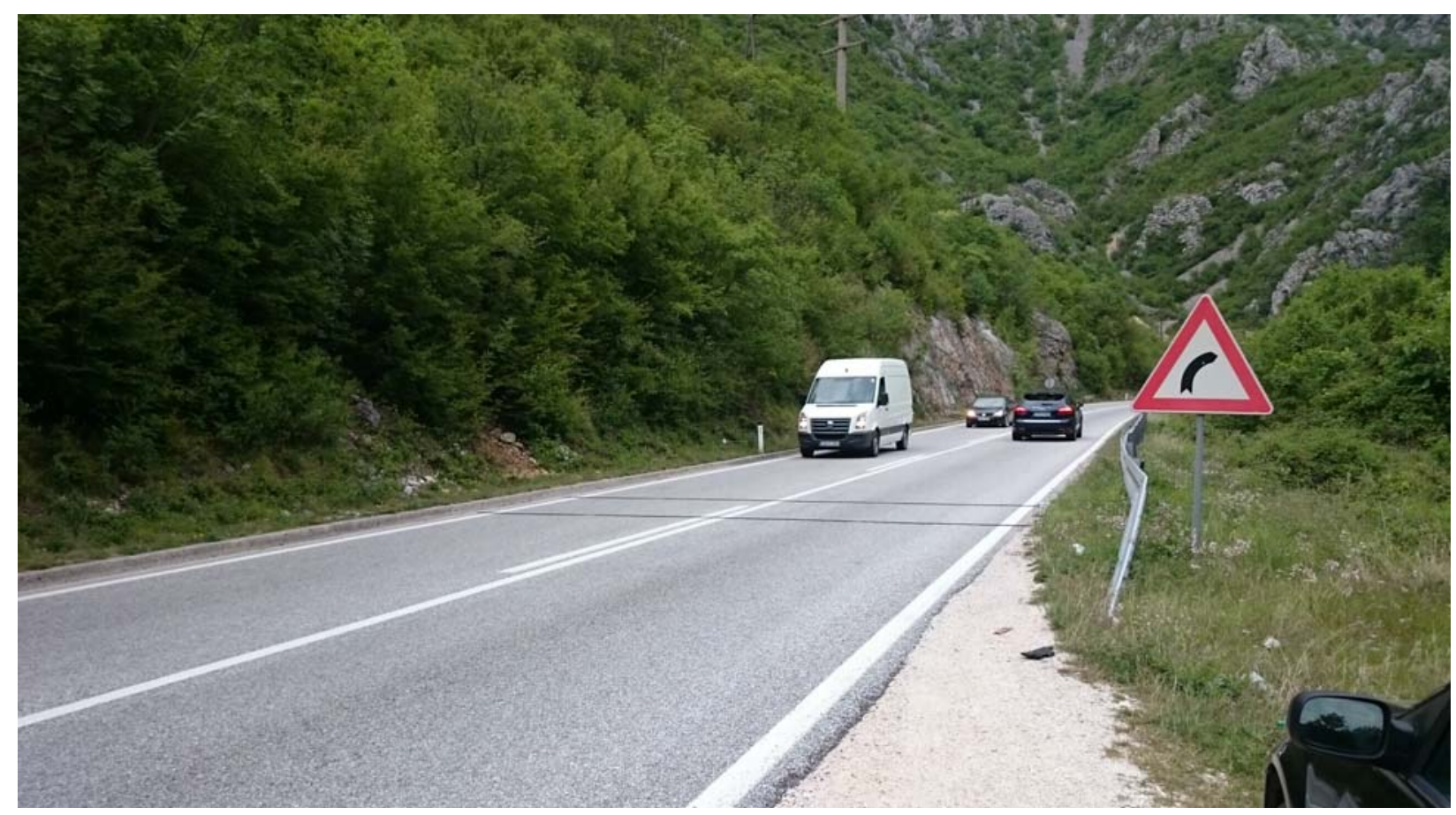

Slika 3.9. Presjek 4 snimanja, pogled u smjeru Sarajevo - Mostar

Sljedeći odabrani presjek je presjek $5(12+150)$ koji se nalazi u Drežnici i smješten je prije zone pretjecanja $700 \mathrm{~m}$ (slika 3.10).

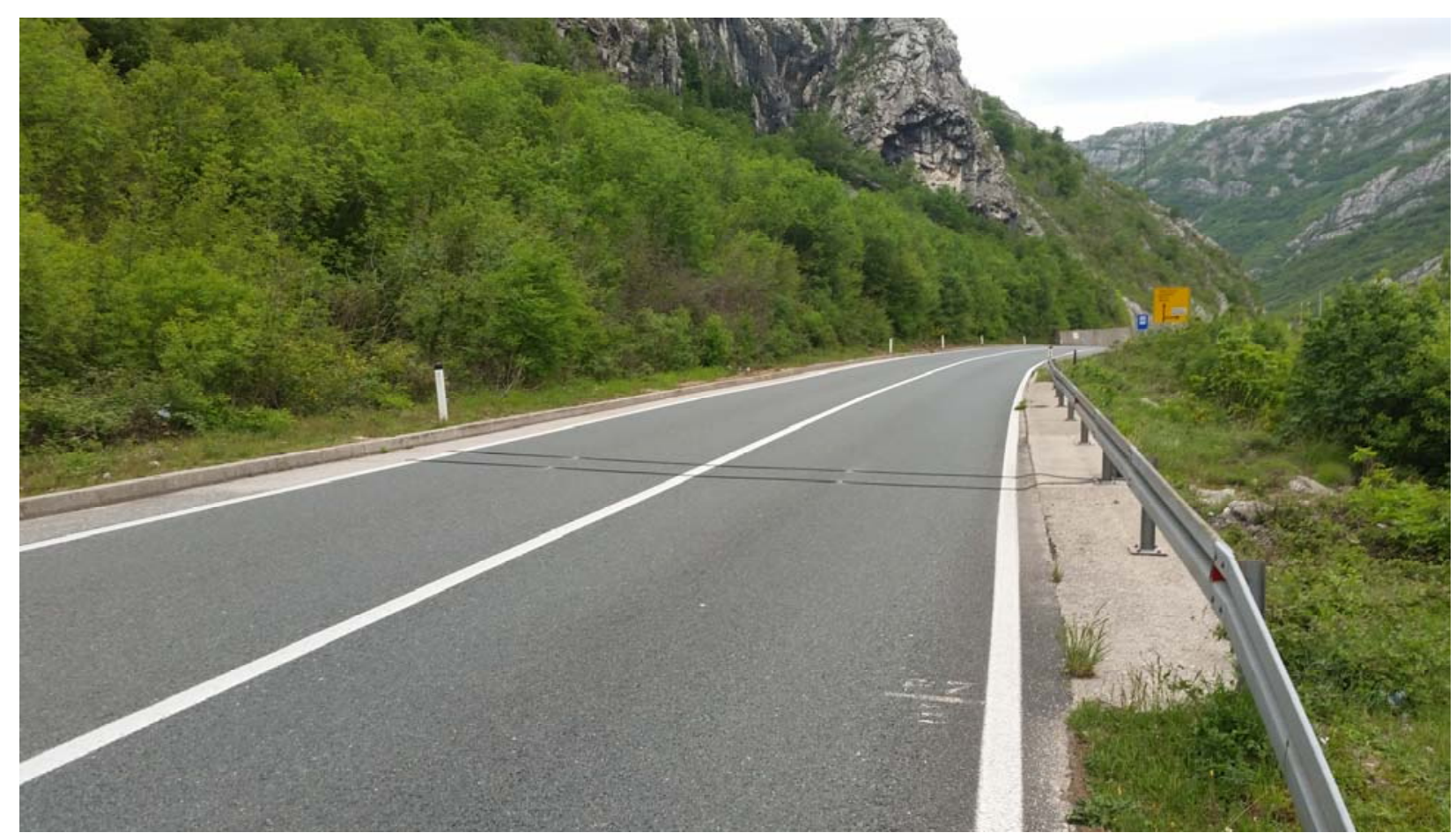

Slika 3.10. Presjek 5 snimanja (prije zone $700 \mathrm{~m}$ ), pogled u smjeru Sarajevo - Mostar

Posljednji odabrani presjek (u prvom postavljanju brojila) je presjek 7 i nalazi se uz branu u Grabovici, neposredno prije tunela (slika 3.11). 


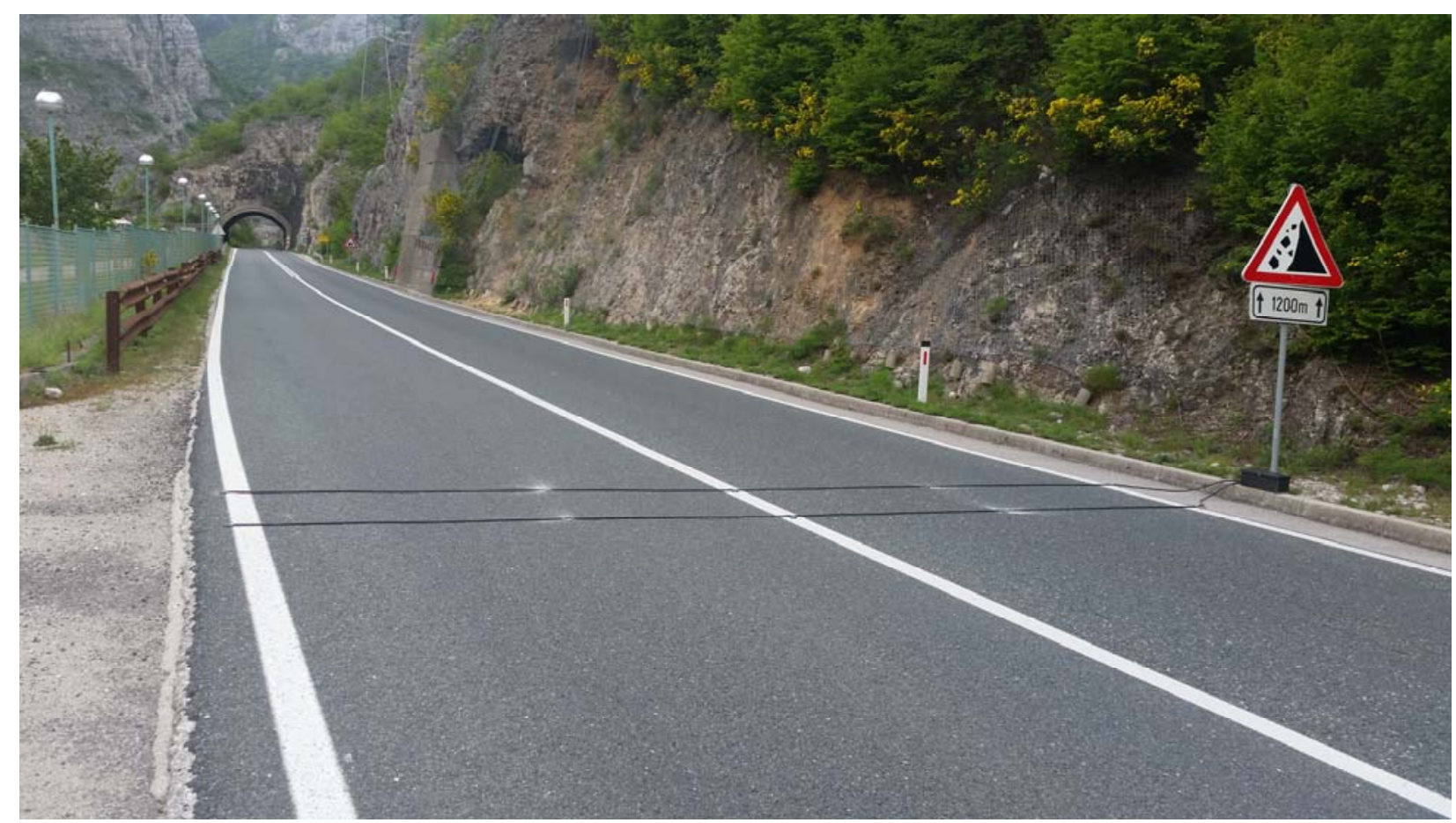

Slika 3.11. Presjek 7 snimanja (ulaz /izlaz u Grabovici), pogled u smjeru Mostar - Sarajevo

Na ovaj način dobio se početni uvid o vrijednostima PTSF-a na cijeloj dionici. Sljedeća snimanja su urađena na način da su zadržana brojila na presjecima 1, 3 i 5, dok su brojila 4 i 7 premještena na presjeke 2 i 6 (slike 3.12 i 3.13).

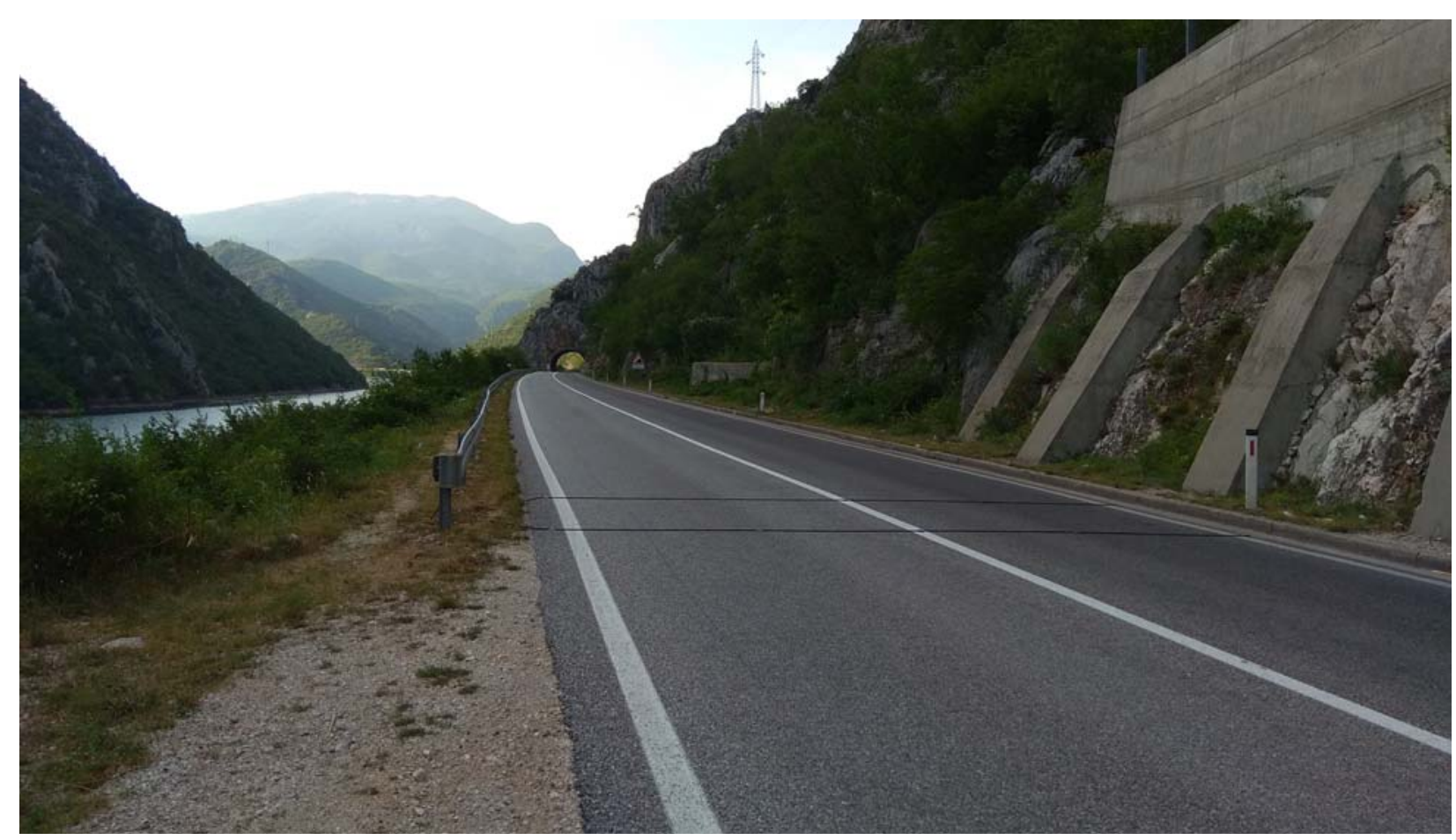

Slika 3.12. Presjek 2 snimanja (prije zone $1100 \mathrm{~m}$ ), pogled u smjeru Mostar - Sarajevo 


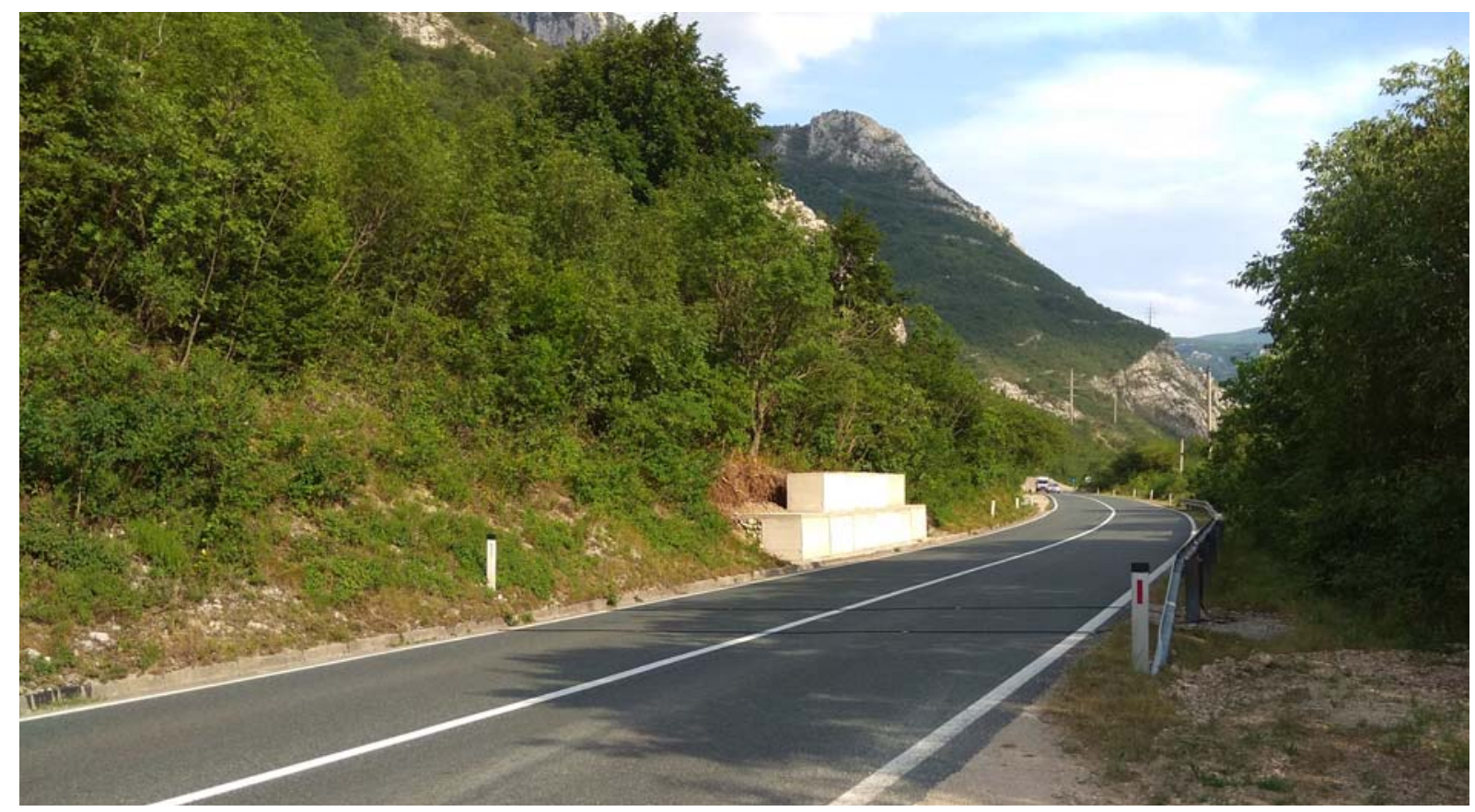

Slika 3.13. Presjek 6 snimanja (poslije zone 700 m), pogled u smjeru Sarajevo - Mostar

Presjeci $2(2+300)$ i $6(13+050)$ bitni su jer zajedno s presjecima 3 i 5 definiraju zone za pretjecanje duljina $1100 \mathrm{~m}$ i $700 \mathrm{~m}$.

Kao što je spomenuto, radi kontrole, izvršena su snimanja videokamerom na 4 lokacije. $\mathrm{Na}$ lokacijama 1 i 3 snimane su zone pretjecanja duljina $1100 \mathrm{~m}$ i $700 \mathrm{~m}$.

Na slikama 3.14 i 3.15 prikazani su položaji brojila i video kamere za snimanje zone $1100 \mathrm{~m}$.

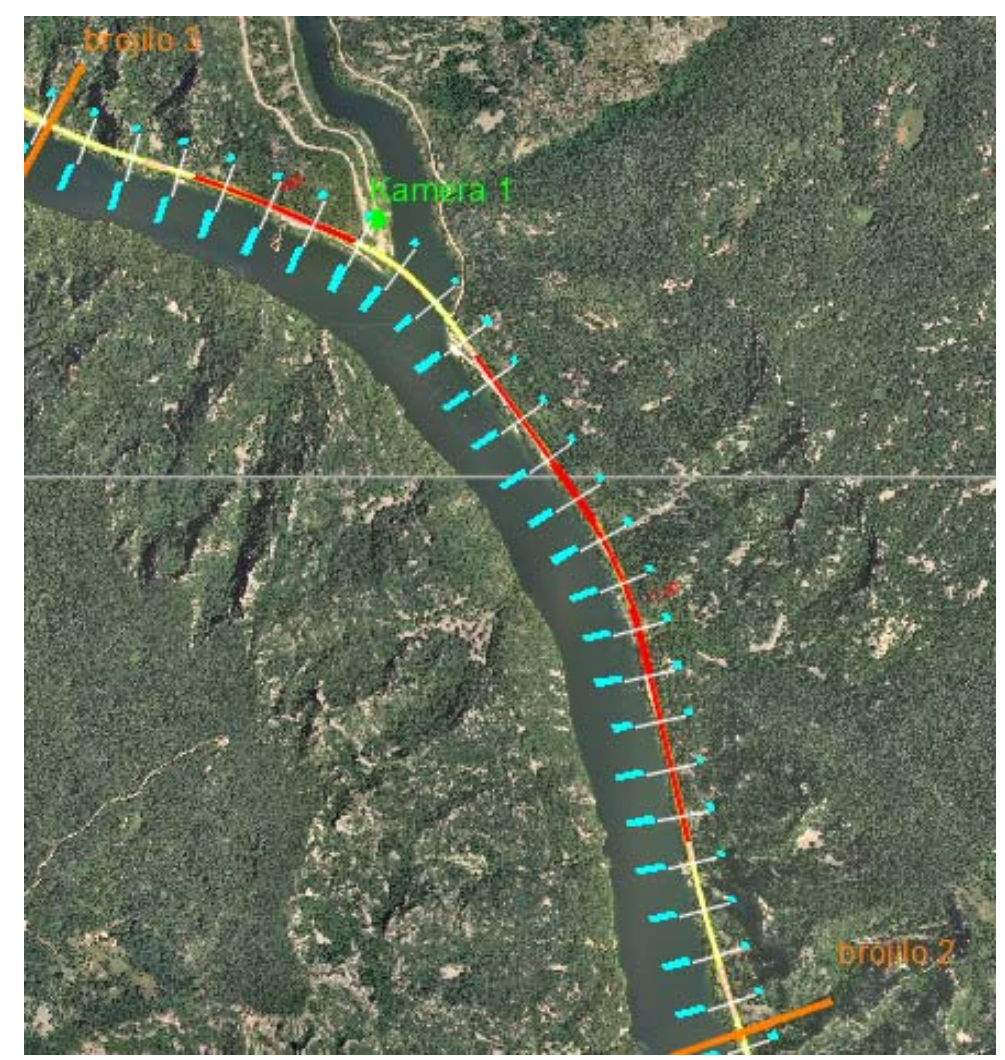

Slika 3.14. Položaj brojila i videokamere za snimanje zone $1100 \mathrm{~m}$ 


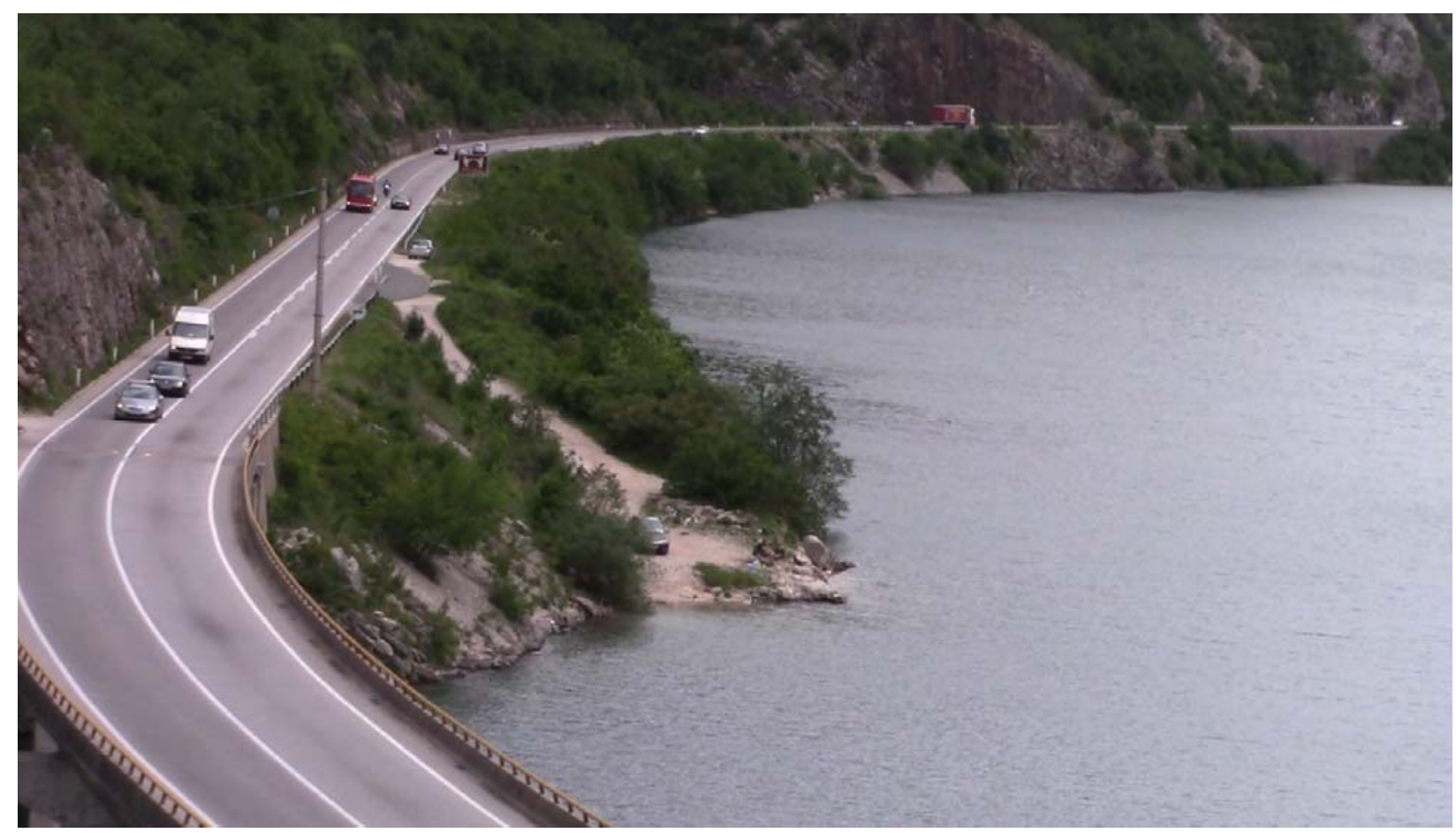

Slika 3.15. Kut snimanja video kamere za snimanje zone $1100 \mathrm{~m}$, pogled u smjeru Sarajevo - Mostar

Zonu pretjecanja duljine $700 \mathrm{~m}$ s položajima brojila i video kamere prikazuju slike $3.16 \mathrm{i}$ 3.17 .

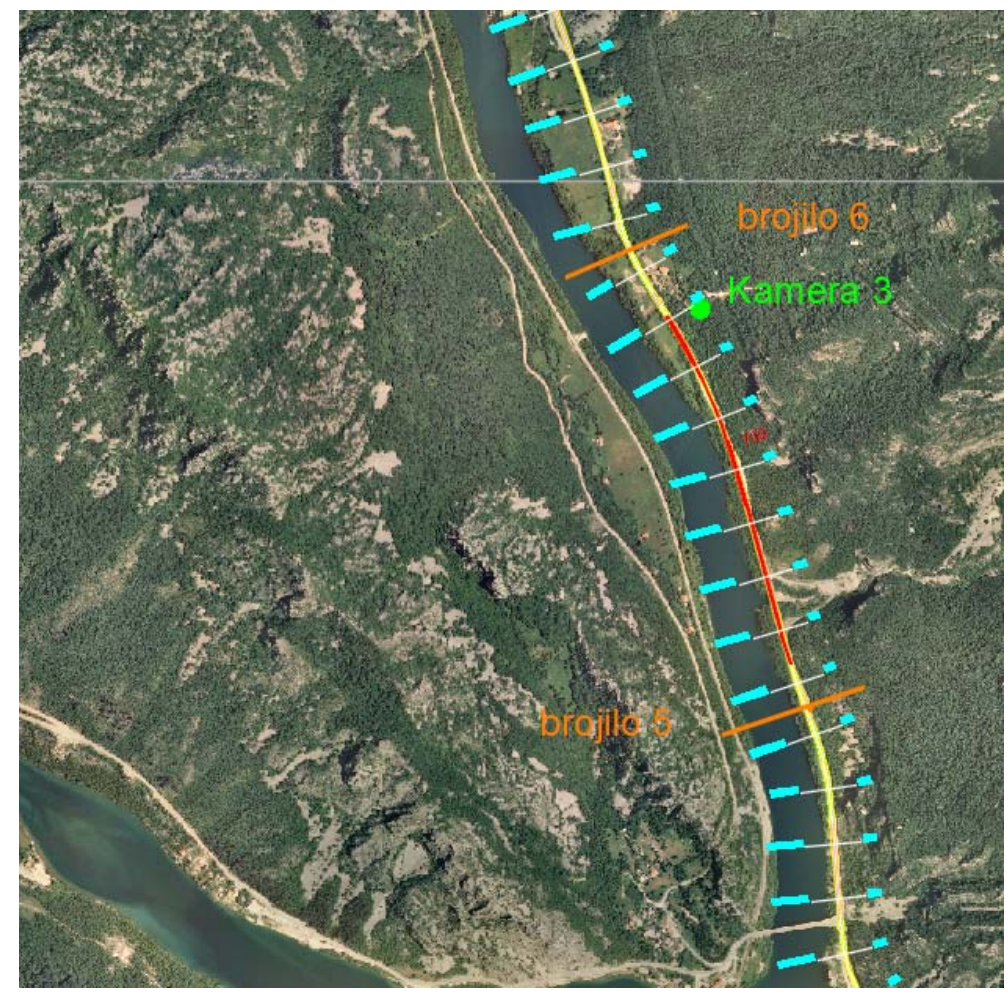

Slika 3.16. Položaj brojila i videokamere za snimanje zone $700 \mathrm{~m}$ 


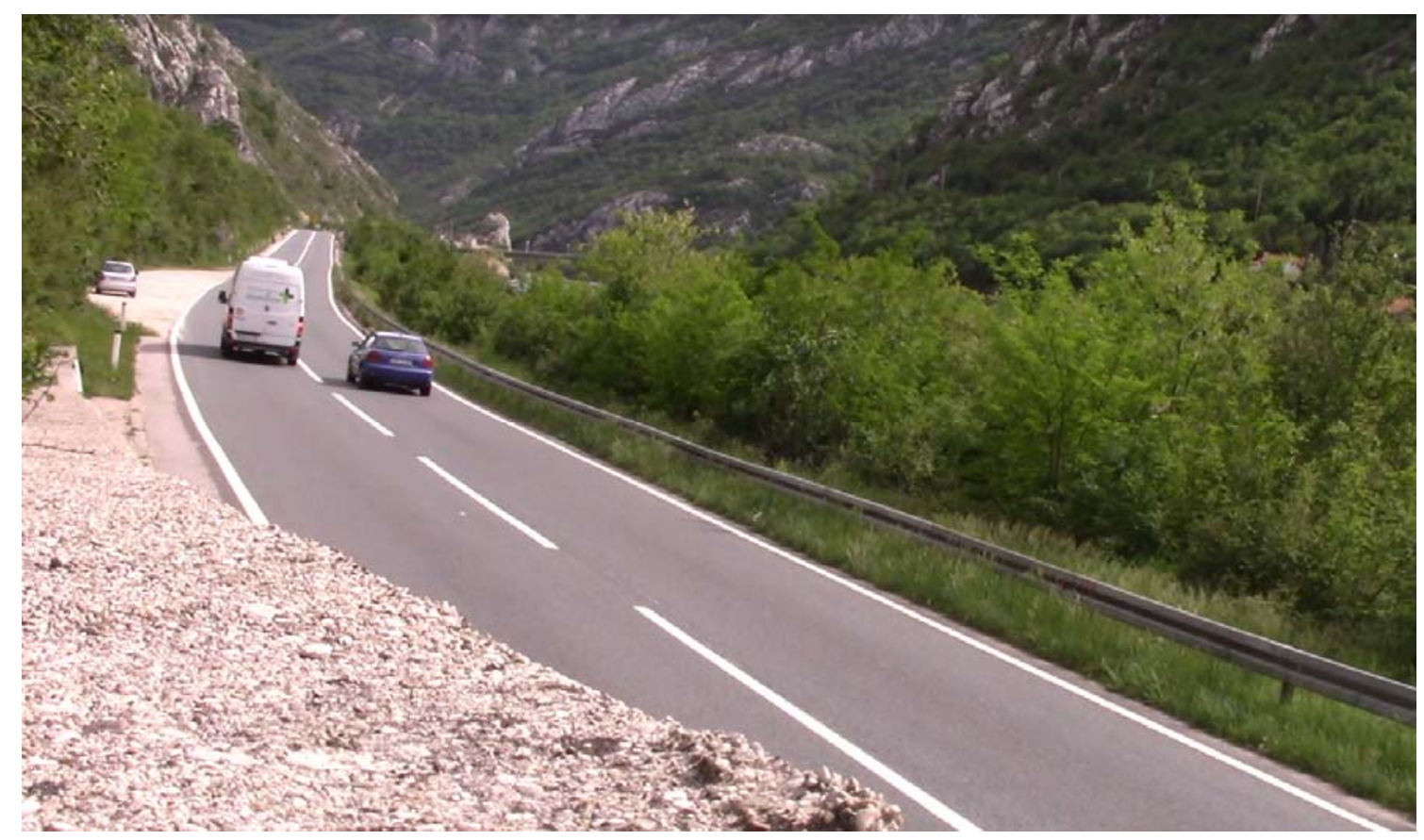

Slika 3.17. Kut snimanja video kamere za snimanje zone $700 \mathrm{~m}$, pogled u smjeru Sarajevo - Mostar

Za snimanje su odabrane zone pretjecanja duljine $450 \mathrm{~m}$ na dijelu dionice stacionaža od $1+100$ do $1+550$ (slike $3.18,3.19$ i 3.20) i dijelu dionice stacionaža od 7+100 do 7+550 (slike 3.21, 3.22 i 3.23) za smjer Salakovac - Grabovica. Postojeći presjek 2 zajedno s novim 1.1 definira prvu zonu, a 3.1 i 3.2 drugu zonu za pretjecanje.

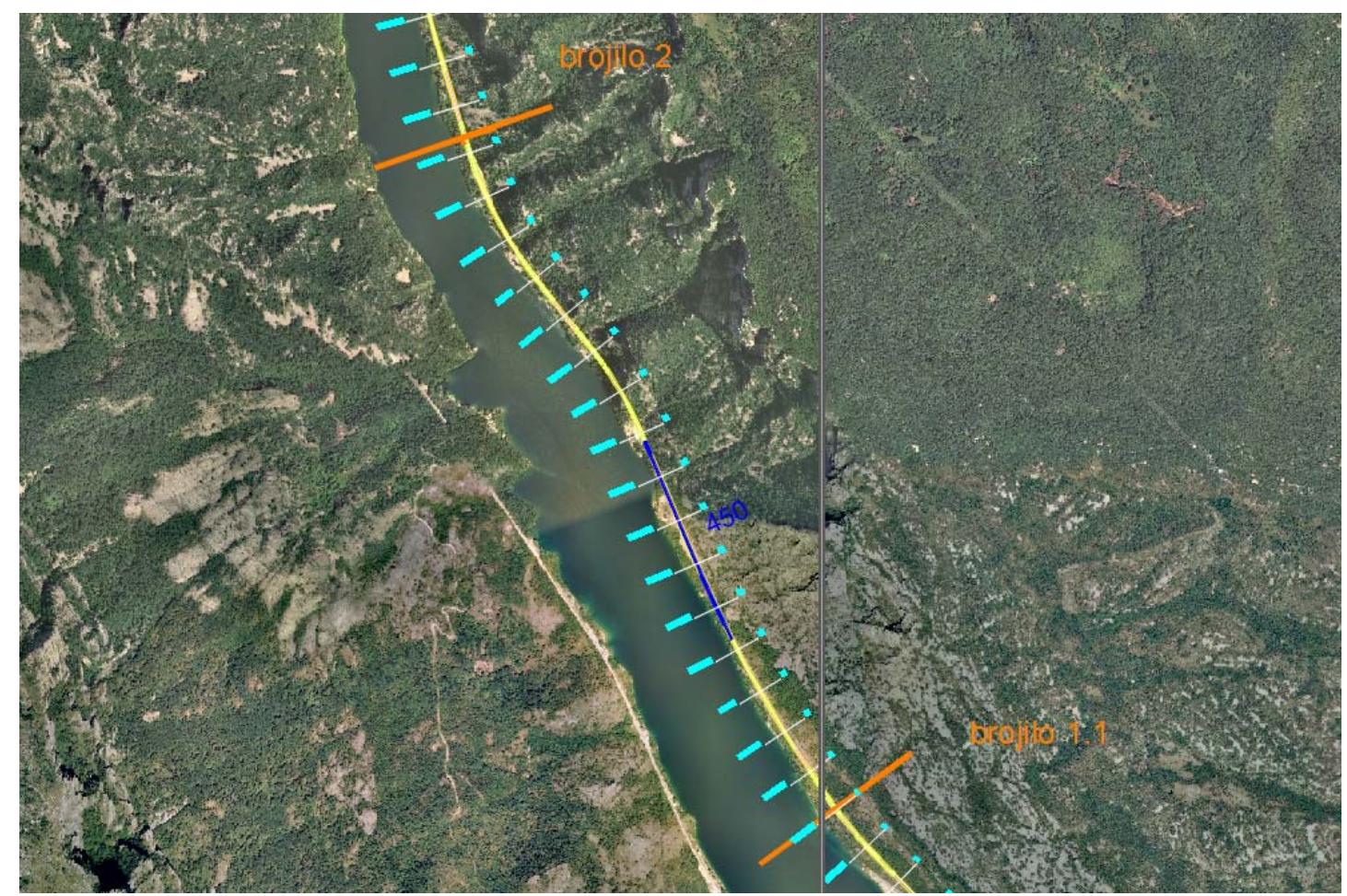

Slika 3.18. Položaji snimanja za zonu $450 \mathrm{~m}(1+100-1+550)$ 


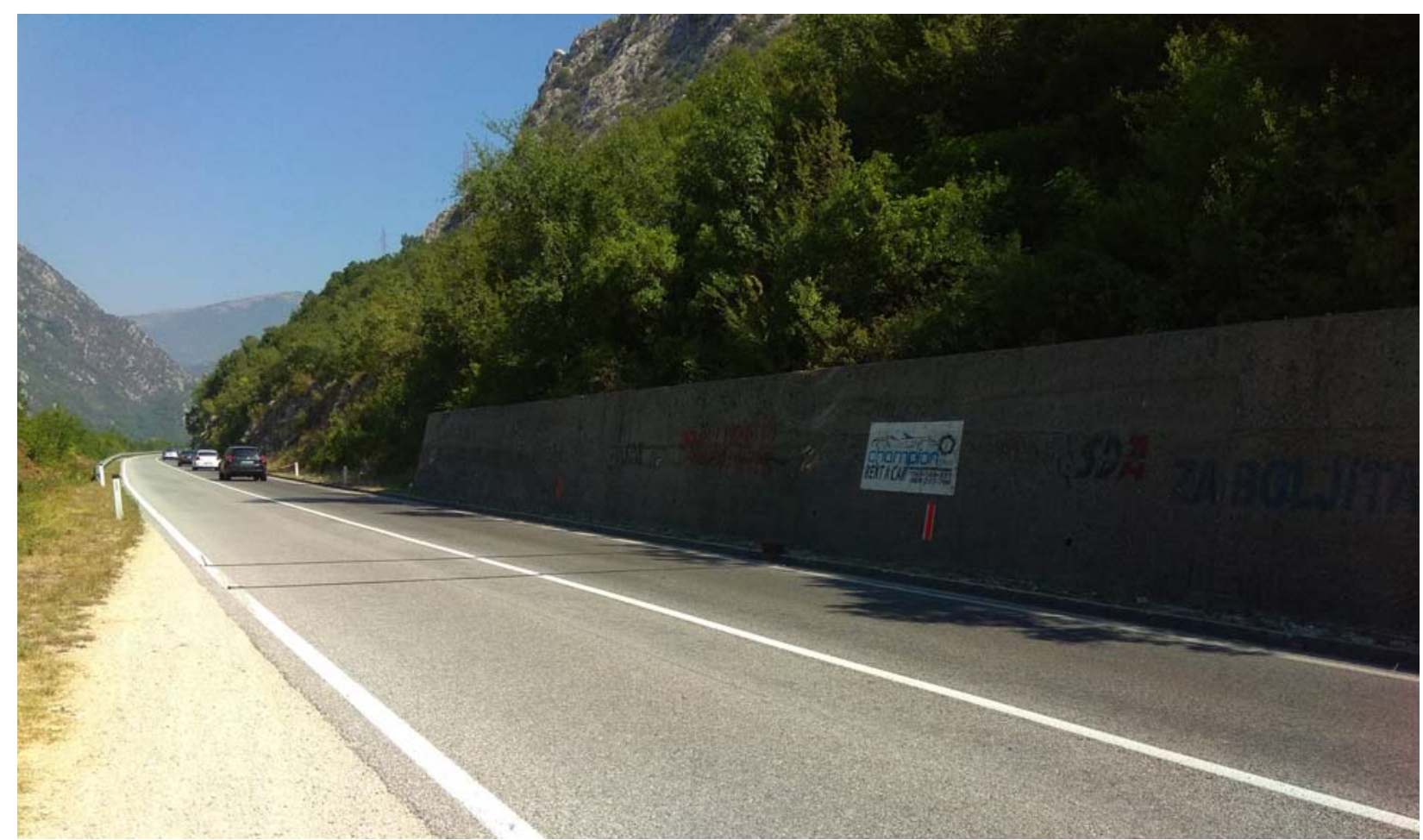

Slika 3.19. Presjek 1.1 snimanja (prije zone 450 m), pogled u smjeru Mostar - Sarajevo

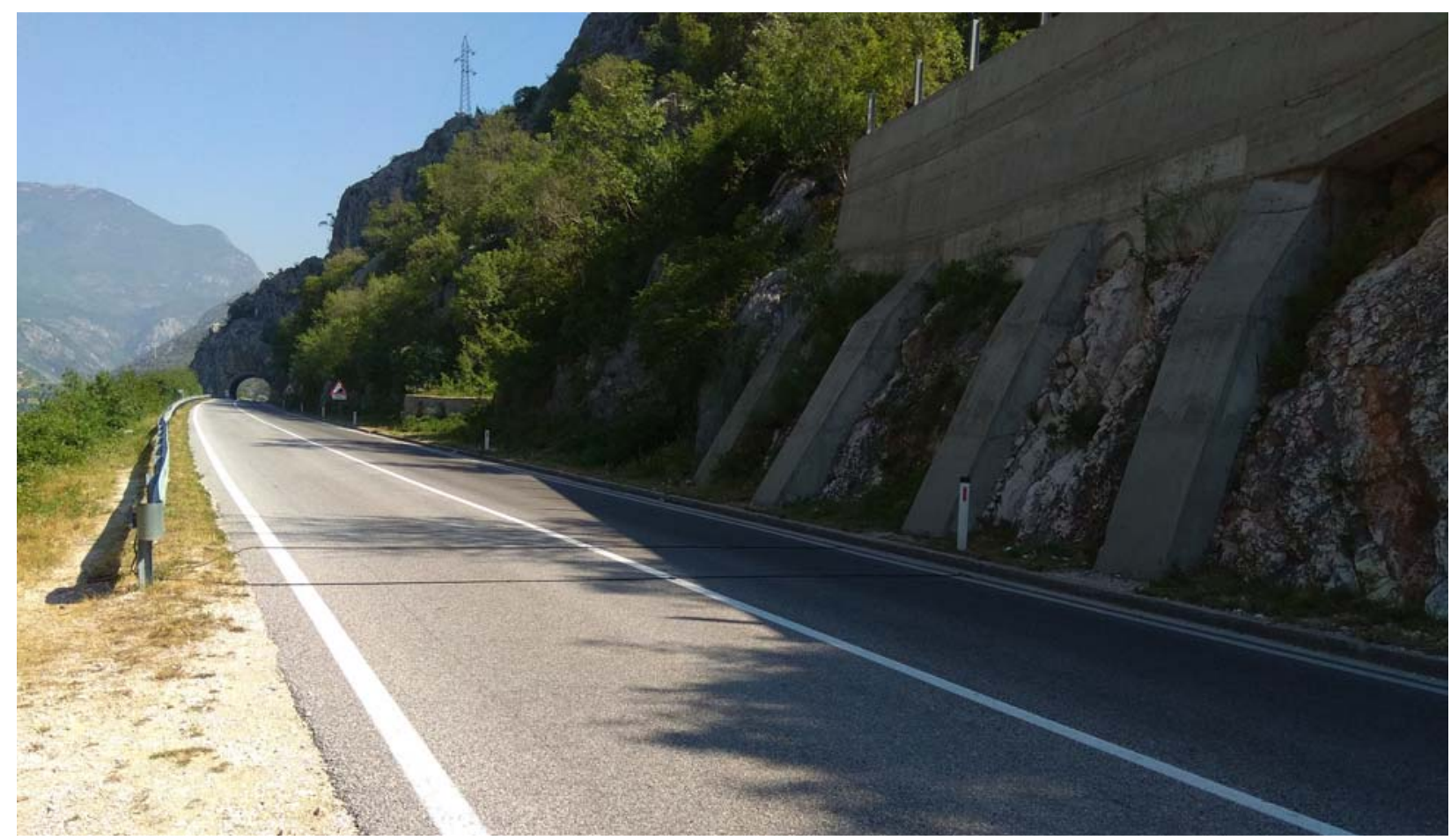

Slika 3.20. Presjek 2 snimanja (poslije zone $450 \mathrm{~m}$ ), pogled u smjeru Mostar - Sarajevo

Druga pretjecajna zona duljine $450 \mathrm{~m}$ koja se nalazi između stacionaža 7+100 i 7+550 prikazana je na sljedećim slikama (slike 3.21, 3.22 i 3.23). 


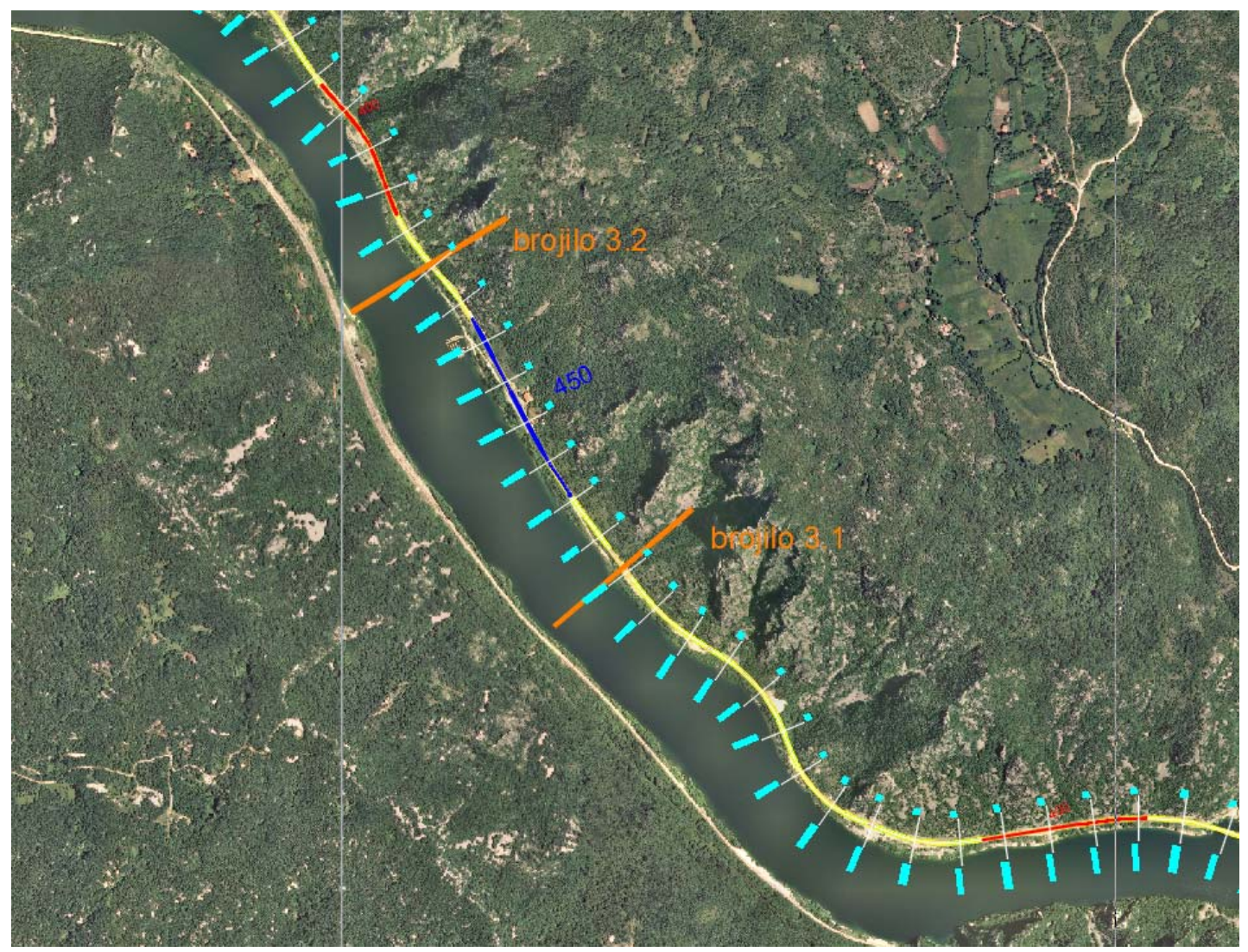

Slika 3.21. Položaji snimanja za zonu $450 \mathrm{~m}(7+100-7+550)$

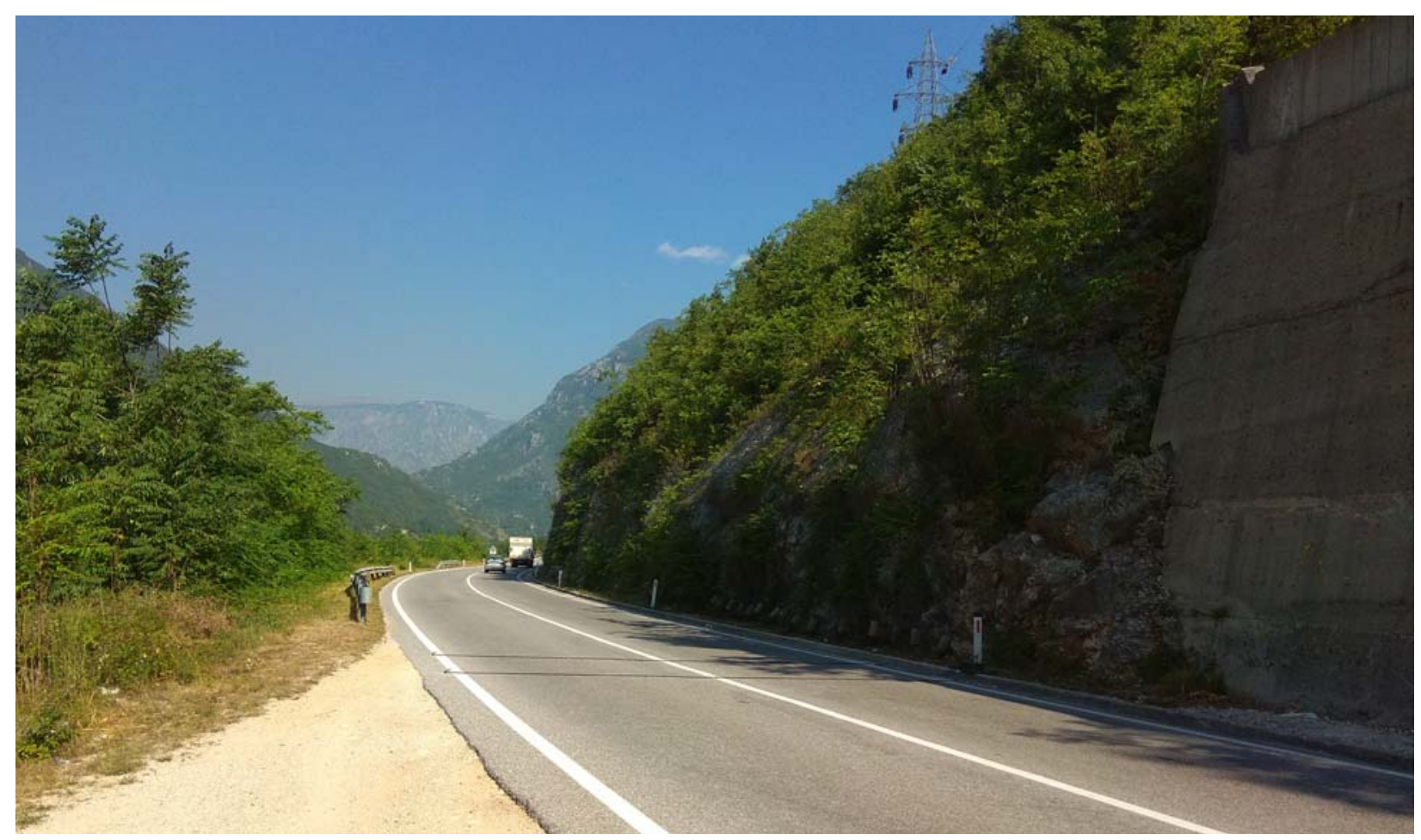

Slika 3.22. Presjek 3.1 snimanja (prije zone $450 \mathrm{~m}$ ), pogled u smjeru Mostar - Sarajevo 


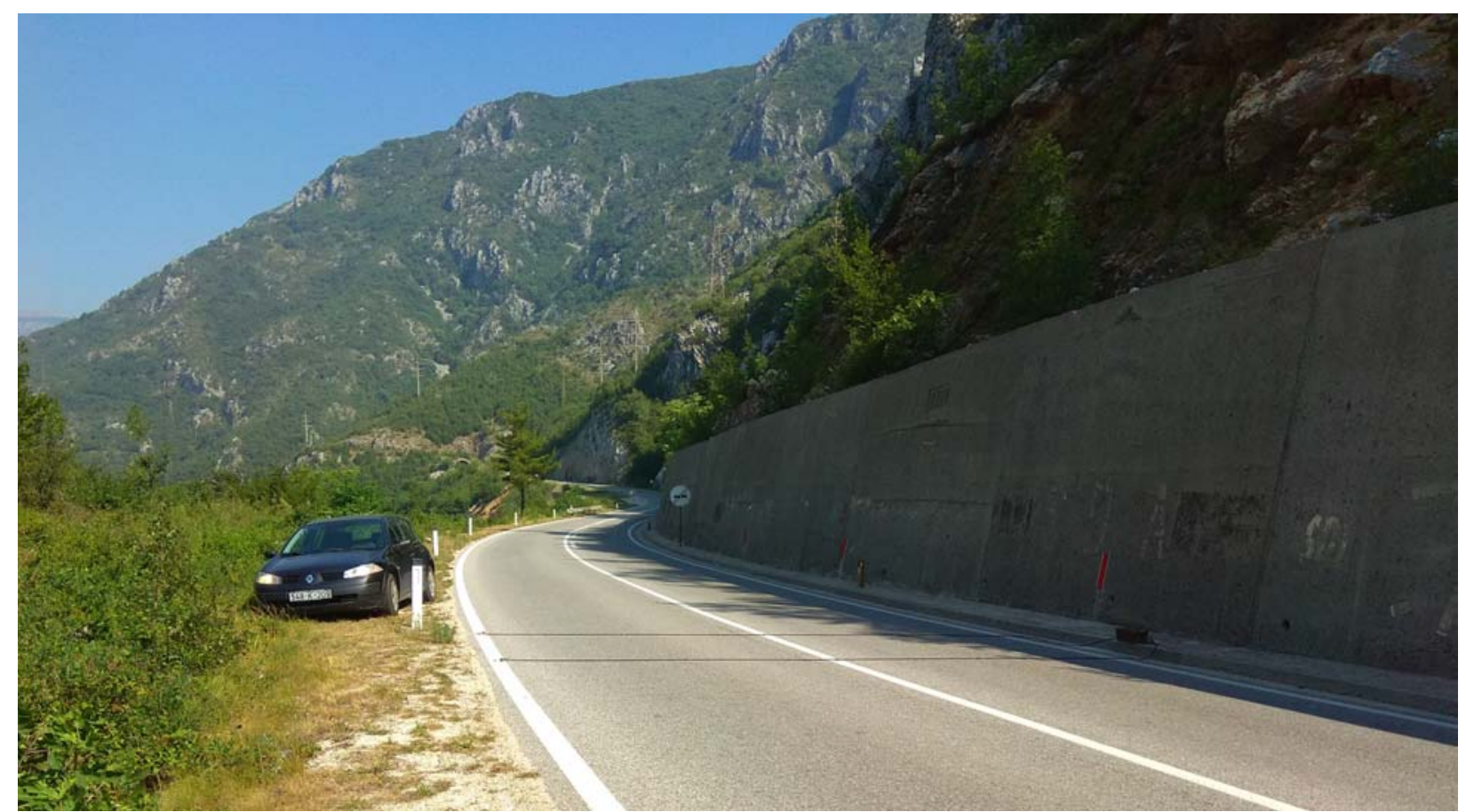

Slika 3.23. Presjek 3.2 snimanja (poslije zone $450 \mathrm{~m}$ ), pogled u smjeru Mostar - Sarajevo

Za provjeru i nadopune podataka korišteno je i radarsko brojilo EasyCount, a osobito kao zamjensko pri uočenim problemima rada (fizička oštećenja) MetroCount brojila. 


\section{ANALIZA REZULTATA ISTRAŽIVANJA}

\subsection{Rezultati istraživanja}

Kao rezultat provedenih terenskih snimanja dobivene su vrijednosti PTSF-a (na temelju vremena prolaska vozila) u ovisnosti o analiziranom smjeru $\left(V_{d}\right)$, suprotnom smjeru $\left(V_{o}\right) i$ postotcima teških teretnih vozila (\% HV). Analizirana su satna (dobivena iz 15-minutnih) opterećenja za oba smjera, Salakovac - Grabovica (Mostar - Sarajevo) i Grabovica - Salakovac (Sarajevo - Mostar).

Rezultati mjerenja za pojedina satna opterećenja (dana u Prilogu I) povezana su regresijski. Nakon analize u kojoj je razmatrano više modela (ponajprije eksponencijalni koji se koristi u HCM-u i u mnogim modelima), najboljim se pokazao logaritamski model višestruke regresije (kao u Španjolskoj [M.1]):

$$
P T S F=a \cdot \ln \left(V_{d}\right)+b \cdot V_{o}-c \cdot H V(b r o j)-d
$$

$\mathrm{U}$ prethodnom izrazu PTSF ovisi o prometnom opterećenju analiziranog $\left(\mathrm{V}_{\mathrm{d}}\right)$ smjera, suprotnog $\left(\mathrm{V}_{\mathrm{o}}\right)$ smjera i broju teških vozila. Koeficijenti a, b, c i d predstavljaju parametre regresijskog modela. Test je pokazao značajnost parametara, osim za utjecaj teških vozila (t test je za parametar c davao $\mathrm{p}$ value $>5 \%$ u svim presjecima). Rezultati regresijske analize dani su $\mathrm{u}$ Prilozima II i III, sa i bez utjecaja teških vozila.

Udio teških vozila se kreće od 5 \% za veća, do $20 \%$ za manja satna opterećenja, prosjek na velikom dijelu mreže je oko 10 \%. Maksimalni broj teških vozila (nekoliko vršnih sati), računajući laka, srednja i teška, na terenu dosegne $90 \mathrm{voz} / \mathrm{h}$ po smjeru. Npr. utjecaj teških vozila na PTSF dobiven na mjernom mjestu 6 je:

$$
P T S F=21.228 \cdot \ln \left(V_{d}\right)+0.009 \cdot V_{o}-0.003 \cdot H V(\text { broj })-70.683
$$

S obzirom na vrijednost parametra uz broj teških vozila (0.003), pored toga što nije pokazao značajnost, može se vidjeti da je i njegov utjecaj zanemariv te će teška vozila biti izostavljena iz daljnjih analiza.

Za svaki analizirani presjek dana je jednadžba za definiranje PTSF-a u kojoj su nezavisne varijable analizirani prometni tok $\mathrm{V}_{\mathrm{d}}$ i suprotni prometni tok $\mathrm{V}_{\mathrm{o}}$ te opći izraz glasi:

$$
P T S F=a \cdot \ln \left(V_{d}\right)+b \cdot V_{o}+c
$$

U analizi su odbačena satna opterećenja manja od $100 \mathrm{voz} / \mathrm{h}$ jer su to vrlo mala opterećenja i vrlo teško je pronaći zakonitosti ponašanja PTSF-a. Također su odbačeni ekstremi, po $10 \%$ minimalnih i maksimalnih vrijednosti. Prometna opterećenja dosežu do 900 voz/h po jednom smjeru i dobivena je dosta dobra korelacija $\left(\mathrm{R}^{2}>0.7\right.$ na većini presjeka). 
Prikazani su rezultati za oba smjera te će zbog preglednosti biti prikazani najprije rezultati prvog smjera, a zatim drugog smjera.

\subsubsection{Smjer Salakovac - Grabovica (Mostar - Sarajevo)}

U nastavku su prikazani rezultati PTSF-a na 7 mjernih mjesta s tim da su na istom grafikonu prikazani rezultati mjernih mjesta 2 i 3 te 5 i 6 jer su to presjeci prije i poslije zona pretjecanja 1100 m i 700 m i time se omogućuje lakše praćenje njihovog utjecaja.

Grafikon 4.1 prikazuje mjerno mjesto 1 koje se nalazi na početku dionice u Salakovcu, za smjer Salakovac - Grabovica (Mostar - Sarajevo) i smatra se ,ulaznim“ PTSF-om.

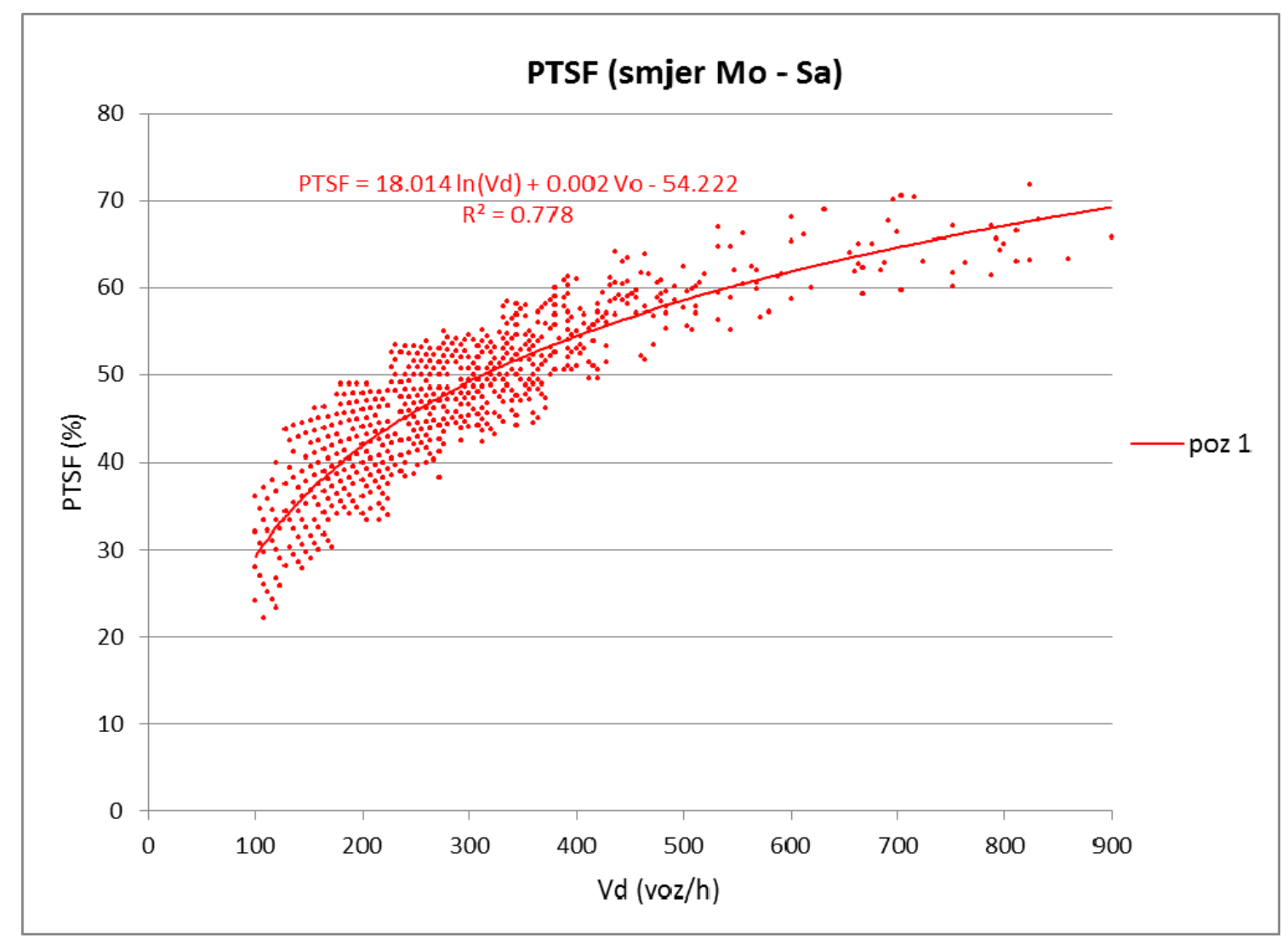

Grafikon 4.1. Rezultati mjernog mjesta 1, smjer Salakovac - Grabovica (brojilo 1)

Na grafikonu 4.2 prikazani su zajedno rezultati mjernih mjesta 2 i 3 (stacionaže $2+300$ i $5+000)$, prije i poslije pretjecajne zone $1100 \mathrm{~m}$.

S grafikona 4.2 može se vidjeti da PTSF značajno opada na mjernom mjestu 3 u odnosu na 2, što znači da zona pretjecanja ima veliki utjecaj. Naravno, najveći utjecaj je za mala opterećenja, a zatim opada povećanjem opterećenja. Obje krivulje su u istom logaritamskom obliku, stoga je vrlo jednostavno njihovom razlikom dobiti promjenu PTSF-a. Utjecaj zone pretjecanja je i veći od same razlike jer da nema pretjecanja PTSF bi rastao od presjeka 2 do presjeka 3. 


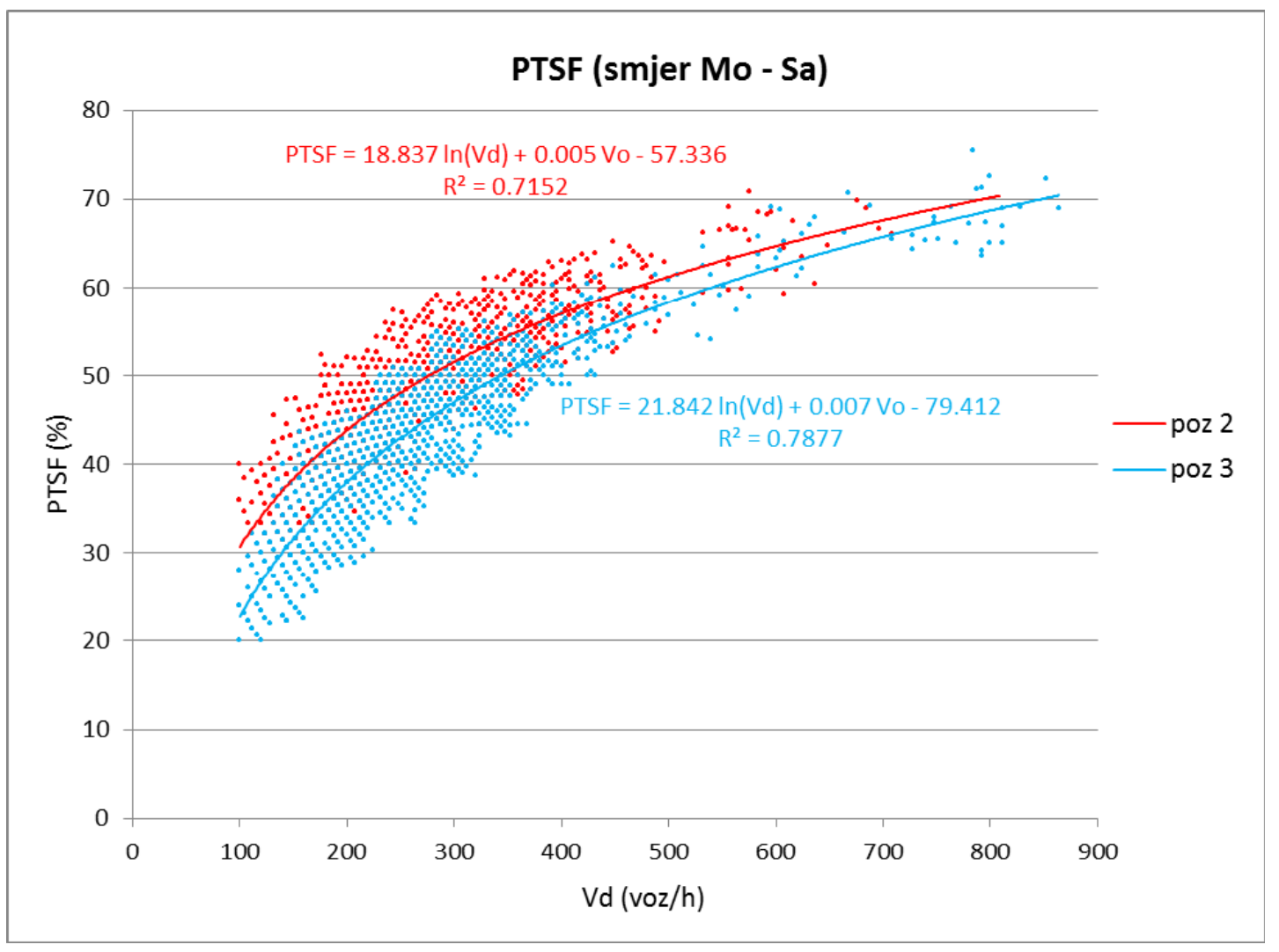

Grafikon 4.2. Rezultati mjernih mjesta 2 i 3, smjer Salakovac - Grabovica (brojila 2 i 3)

Na sljedećem grafikonu 4.3 su rezultati mjerenja na mjernom mjestu 4 koje je smješteno na devetom kilometru $(8+900)$.

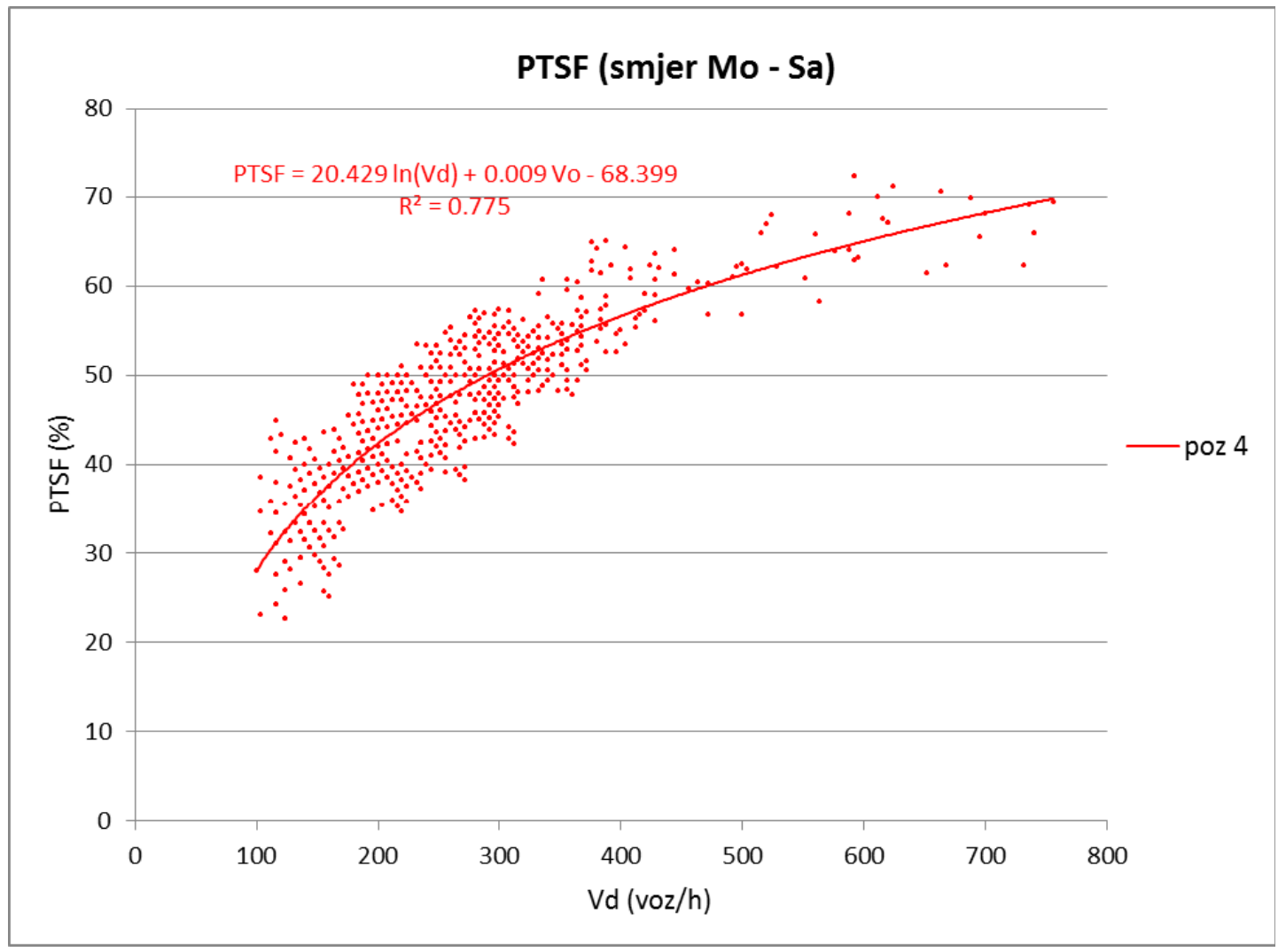

Grafikon 4.3. Rezultati mjernog mjesta 4, smjer Salakovac - Grabovica (brojilo 4) 
Mjerna mjesta 5 i 6 (prikazana grafikonom 4.4) nalaze se u Drežnici i prikazuju mjerenja prije i poslije zone pretjecanja $700 \mathrm{~m}$ (stacionaže $12+150$ i 13+050).

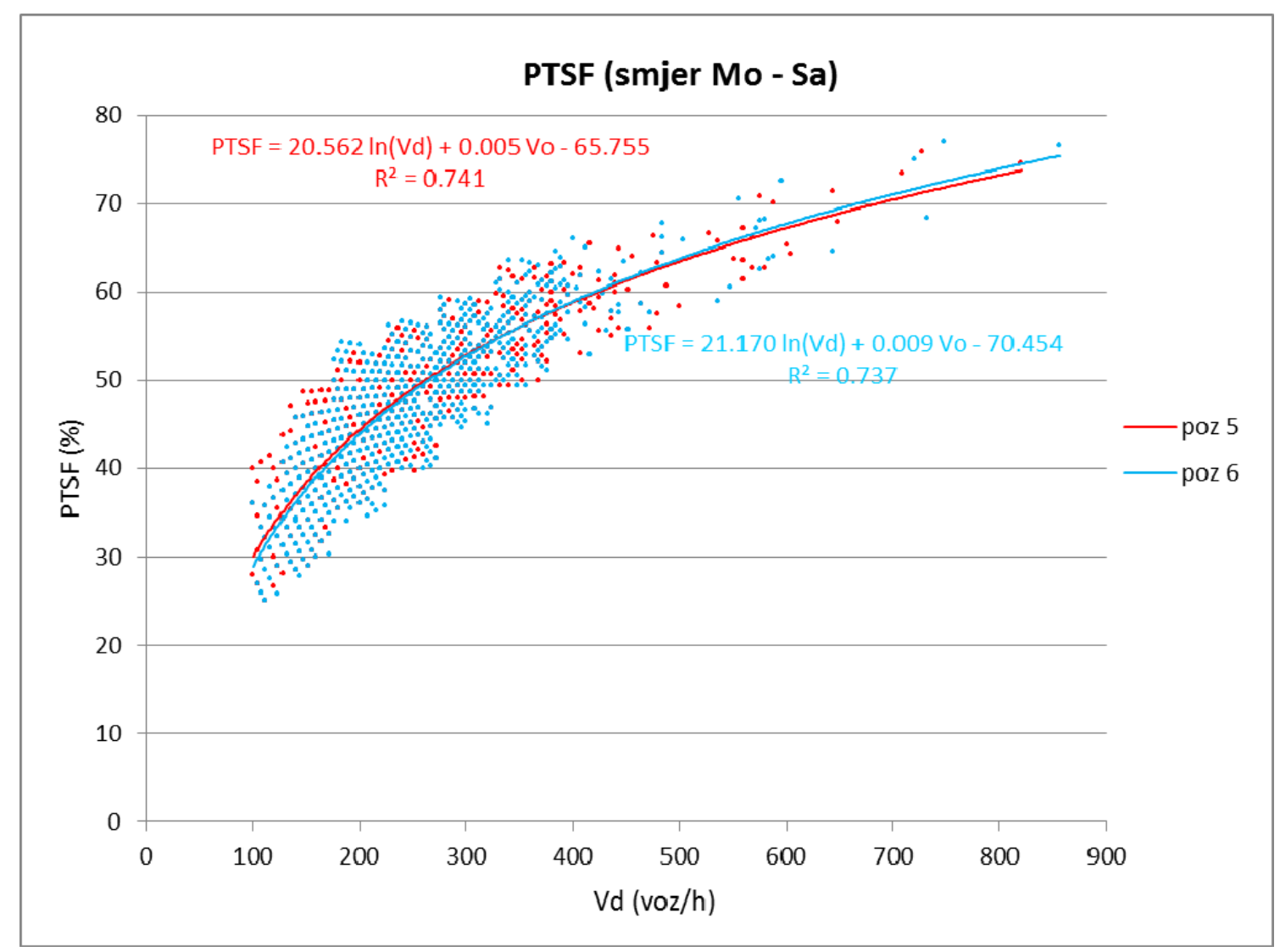

Grafikon 4.4. Rezultati mjernih mjesta 5 i 6, smjer Salakovac - Grabovica (brojila 5 i 6 )

S krivulja na grafikonu može se vidjeti da je PTSF mjernog mjesta 6 manji u odnosu na 5 do nekih $300 \mathrm{voz} / \mathrm{h}$ analiziranog smjera, a zatim je veći kako se opterećenje povećava. To je logično jer se povećanjem opterećenja smanjuje mogućnost pretjecanja.

Utjecaj zone pretjecanja (broj pretjecanja) za ista opterećenja je manji za ovaj smjer od suprotnog (Grabovica - Salakovac). Razlog tomu je znatno lošija preglednost smjera Salakovac - Grabovica u odnosu na suprotni. Naime, odmah iza zone pretjecanja je oštra krivina i ne ispunjava se potpuno potencijal pretjecajne zone.

Kao i kod zone 1100 m (mjerna mjesta 2 i 3), utjecaj zona pretjecanja se može dobiti iz razlike krivulja.

Na kraju analizirane dionice (u Grabovici, 19+700) nalazi se mjerno mjesto 7 prikazano grafikonom 4.5 . 


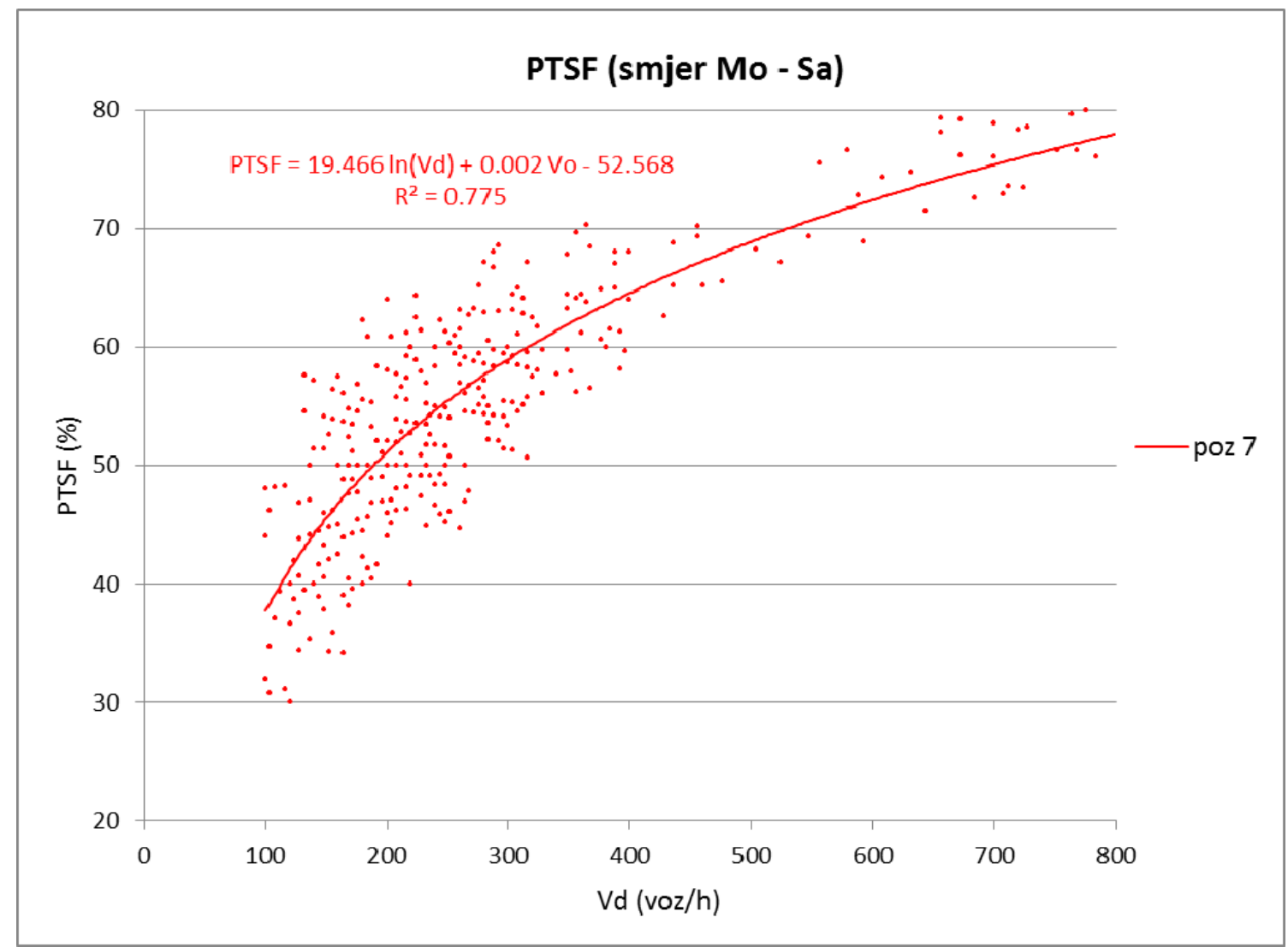

Grafikon 4.5. Rezultati mjernog mjesta 7, smjer Salakovac - Grabovica (brojilo 7)

Rezultati sa svih 7 mjernih mjesta mogu se regresijski povezati logaritamskim modelom (prikazano i na grafikonima).

Mjerno mjesto 1 (stacionaža 0+000):

$$
P T S F_{1}=18.014 \cdot \ln \left(V_{d}\right)+0.002 \cdot V_{o}-54.222
$$

Mjerno mjesto 2 (stacionaža 2+300):

$$
P T S F_{2}=18.837 \cdot \ln \left(V_{d}\right)+0.005 \cdot V_{o}-57.336
$$

Mjerno mjesto 3 (stacionaža 5+000):

$$
P T S F_{3}=21.842 \cdot \ln \left(V_{d}\right)+0.007 \cdot V_{o}-79.412
$$

Mjerno mjesto 4 (stacionaža 8+900):

$$
\mathrm{PTSF}_{4}=20.429 \cdot \ln \left(V_{d}\right)+0.009 \cdot V_{o}-68.399
$$

Mjerno mjesto 5 (stacionaža 12+150):

$$
P_{T S F_{5}}=20.562 \cdot \ln \left(V_{d}\right)+0.005 \cdot V_{o}-65.755
$$

Mjerno mjesto 6 (stacionaža 13+050):

$$
\mathrm{PTSF}_{6}=21.170 \cdot \ln \left(V_{d}\right)+0.009 \cdot V_{o}-70.454
$$


Mjerno mjesto 7 (stacionaža 19+700):

$$
\mathrm{PTSF}_{7}=19.466 \cdot \ln \left(V_{d}\right)+0.002 \cdot V_{o}-52.568
$$

Temeljem navedenih 7 izraza proračunat je PTSF postojeće dionice na način da se prvo izračuna vrijednost PTSF-a svakog segmenta koji se definira kao prosječna vrijednost susjednih presjeka. Zatim se te prosječne vrijednosti pomnože $s$ duljinom pojedinih segmenata, te se njihova suma podijeli s duljinom analizirane dionice.

To znači da se PTSF dionice dobije preko sljedećeg izraza:

$$
P T S F_{\text {dionice }}=\frac{\sum_{i=1}^{6} L_{i, i+1} \cdot\left(P T S F_{i}+P T S F_{i+1}\right) / 2}{L_{\text {dionice }}}
$$

Gdje su:

- $\quad \mathrm{L}_{\mathrm{i}, \mathrm{i}+1}=$ duljina segmenta između presjeka i te presjeka $\mathrm{i}+1(\mathrm{~km})$

- $\quad \mathrm{PTSF}_{\mathrm{i}}=$ vrijednost PTSF-a u presjeku i (\%)

- $\quad \mathrm{L}_{\text {dionice }}=$ duljina cijele dionice $(\mathrm{km})$

Na temelju prethodnih izraza dobije se izraz za PTSF dionice Salakovac - Grabovica:

$$
P T S F_{\text {dionice }}=20.316 \cdot \ln \left(V_{d}\right)+0.006 \cdot V_{o}-65.456
$$

Iz rezultata regresijske analize (prilozi II i III) vidljivo je sljedeće:

- Nije se pokazala statistička signifikantnost nezavisne varijable teških vozila na svim presjecima (Prilog II).

- F - test je pokazao signifikantnost modela (jednadžba 4.3) u svih 7 presjeka i u oba smjera, kao što je i t-test pokazao signifikantnost nezavisnih varijabli istog modela (Prilog III).

- Korigirani koeficijenti determinacije regresijskog modela po presjecima se kreću u rasponu od 0.7 do 0.8 . Može se zaključiti da je na razini cijele dionice $75 \%$ odstupanja objašnjeno modelom (Prilog III).

Jednaki rezultati su dobiveni i za suprotni smjer Grabovica - Salakovac koji je prikazan u nastavku.

\subsubsection{Smjer Grabovica - Salakovac (Sarajevo - Mostar)}

Za smjer Grabovica - Salakovac vrijede iste zakonitosti kao i za prvi smjer. U nastavku su prikazani rezultati po mjernim mjestima, uz obrnuti redoslijed.

Grafikon 4.6 prikazuje mjerno mjesto 7 koje se nalazi na početku dionice u Grabovici, za smjer Grabovica - Salakovac i smatra se „ulaznim“ PTSF-om. 


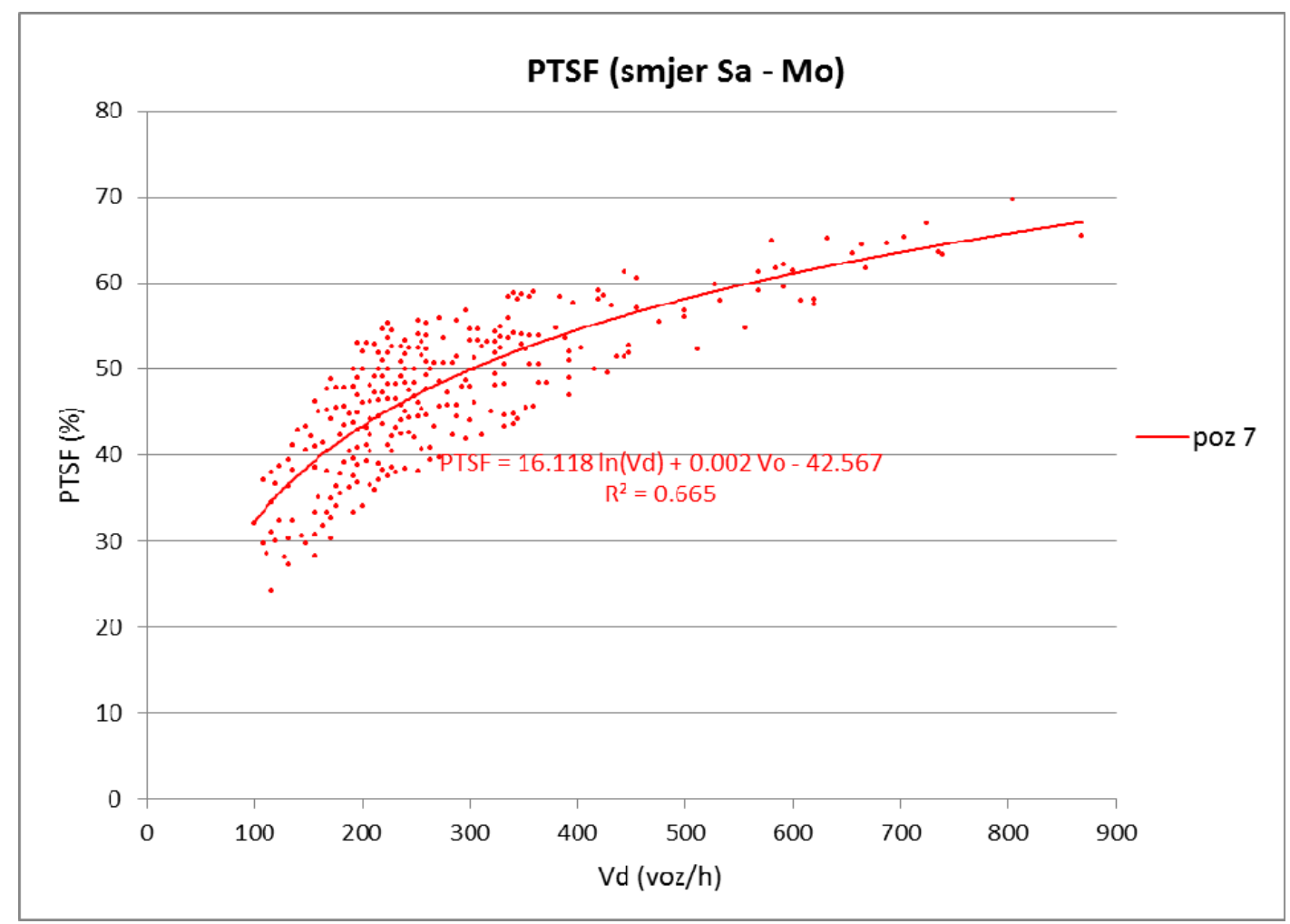

Grafikon 4.6. Rezultati mjernog mjesta 7, smjer Grabovica - Salakovac (brojilo 7)

$\mathrm{Na}$ grafikonu 4.7 prikazani su rezultati mjerenja prije i poslije zone pretjecanja $700 \mathrm{~m}$ (stacionaže $6+650$ i $7+550$ ).

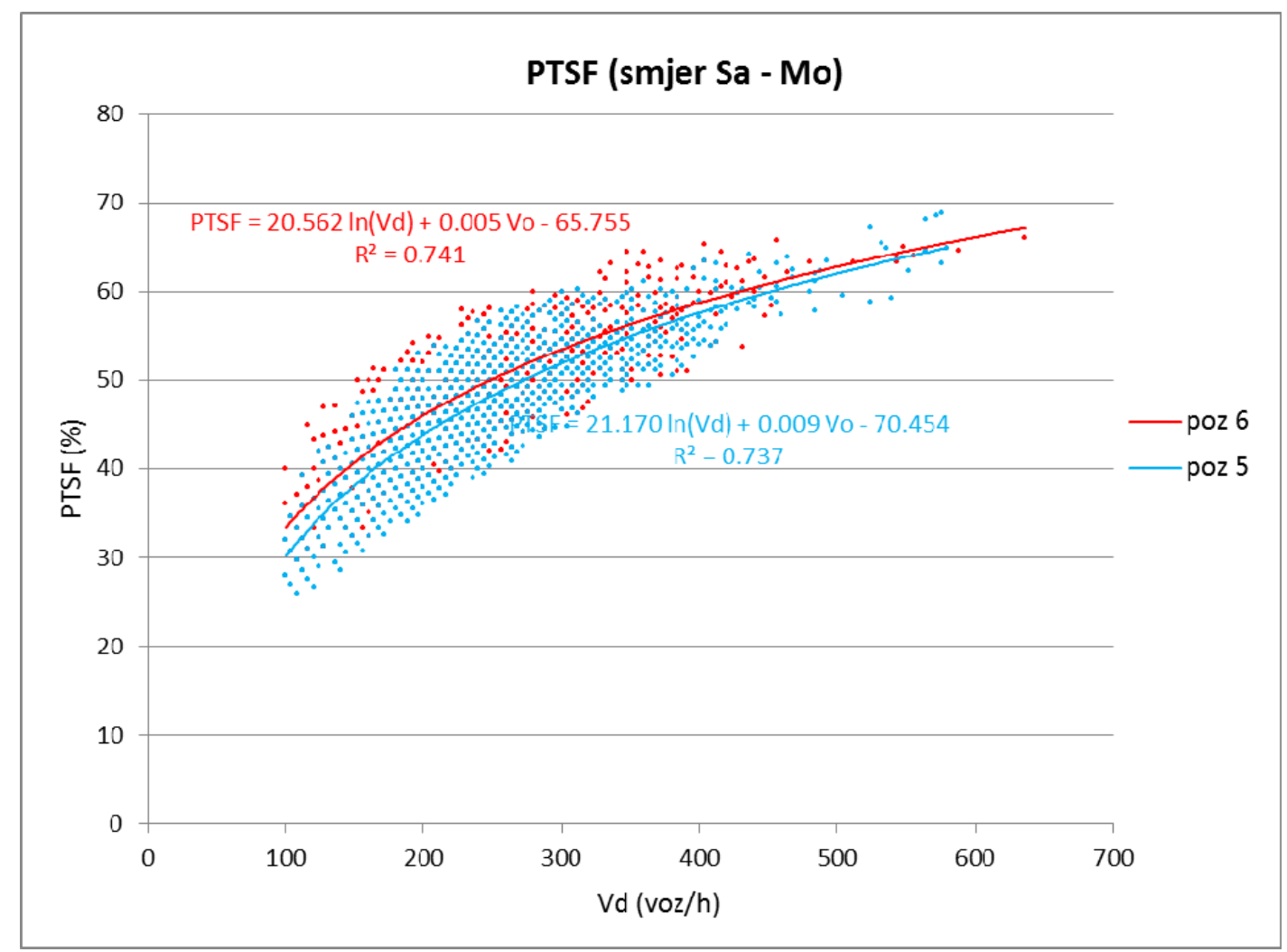

Grafikon 4.7. Rezultati mjernih mjesta 6 i 5, smjer Grabovica - Salakovac (brojila 6 i 5) 
Kao što se vidi PTSF na presjeku 5 pada u odnosu na prethodni presjek 6, što znači da zona pretjecanja ima veći utjecaj nego je to bio slučaj za suprotni smjer.

Razlog je u mnogo boljoj preglednosti u ovom smjeru i stoga se ostvaruje veći broj pretjecanja.

Na grafikonu 4.8 su rezultati mjerenja na mjernom mjestu 4 koje je smješteno točno na kraju jedanaestog kilometra $(10+800)$.

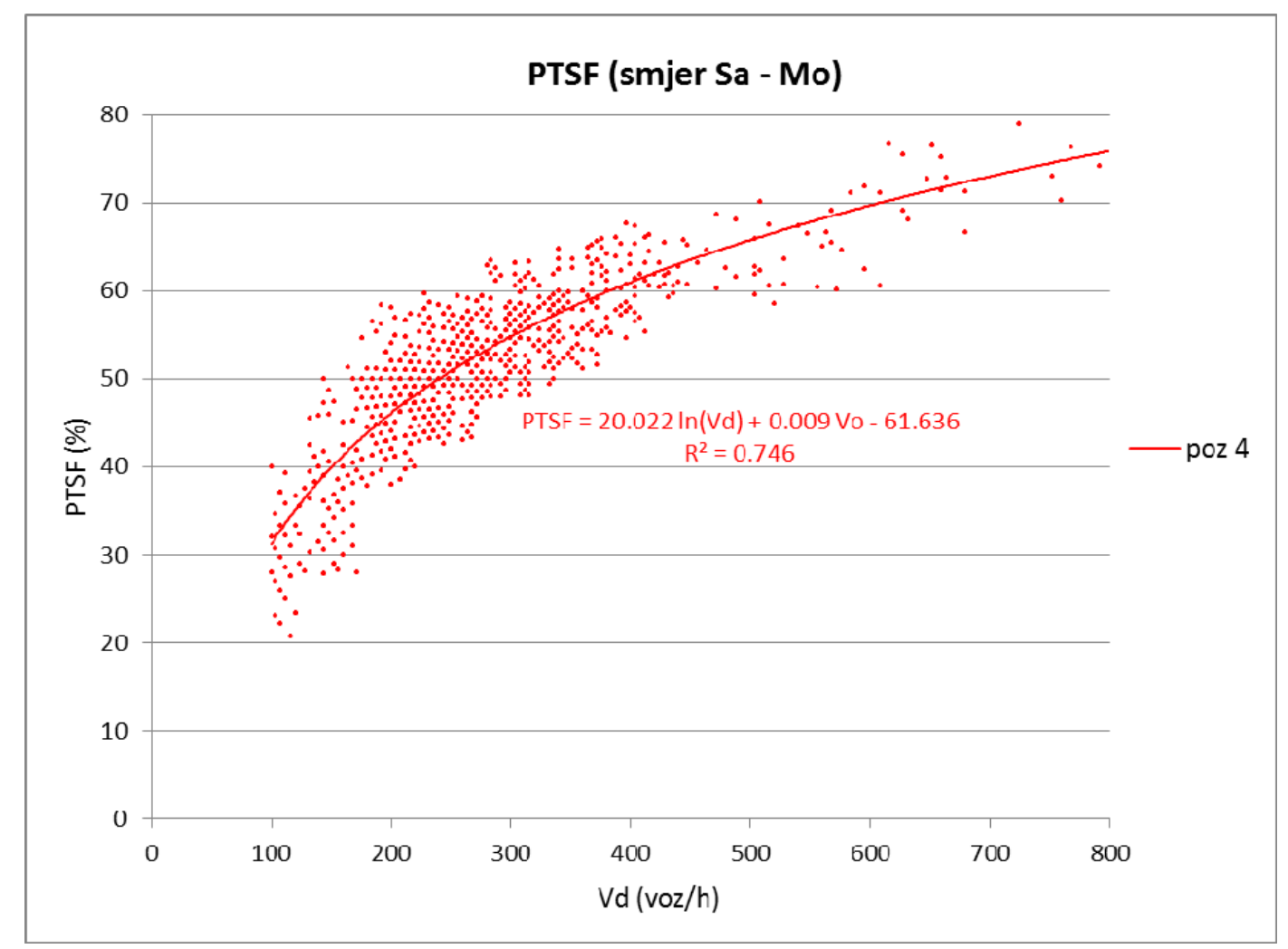

Grafikon 4.8. Rezultati mjernog mjesta 4, smjer Grabovica - Salakovac (brojilo 4)

Rezultati mjernih mjesta 3 i 2 (stacionaže $14+700$ i 17+400), prije i poslije pretjecajne zone 1100 m, prikazuju slične rezultate kao i suprotni smjer (grafikon 4.9). 


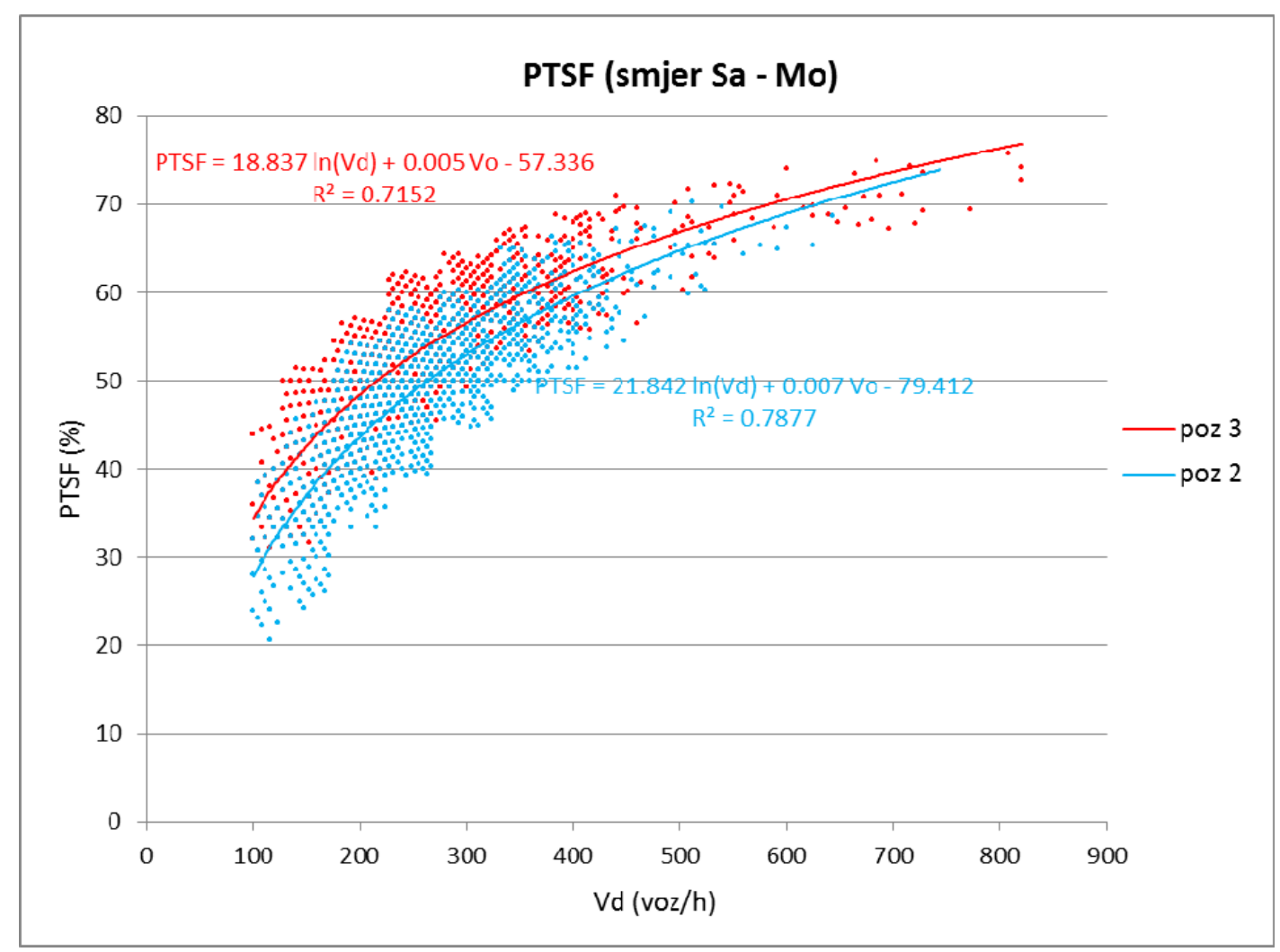

Grafikon 4.9. Rezultati mjernih mjesta 3 i 2, smjer Grabovica - Salakovac (brojila 3 i 2)

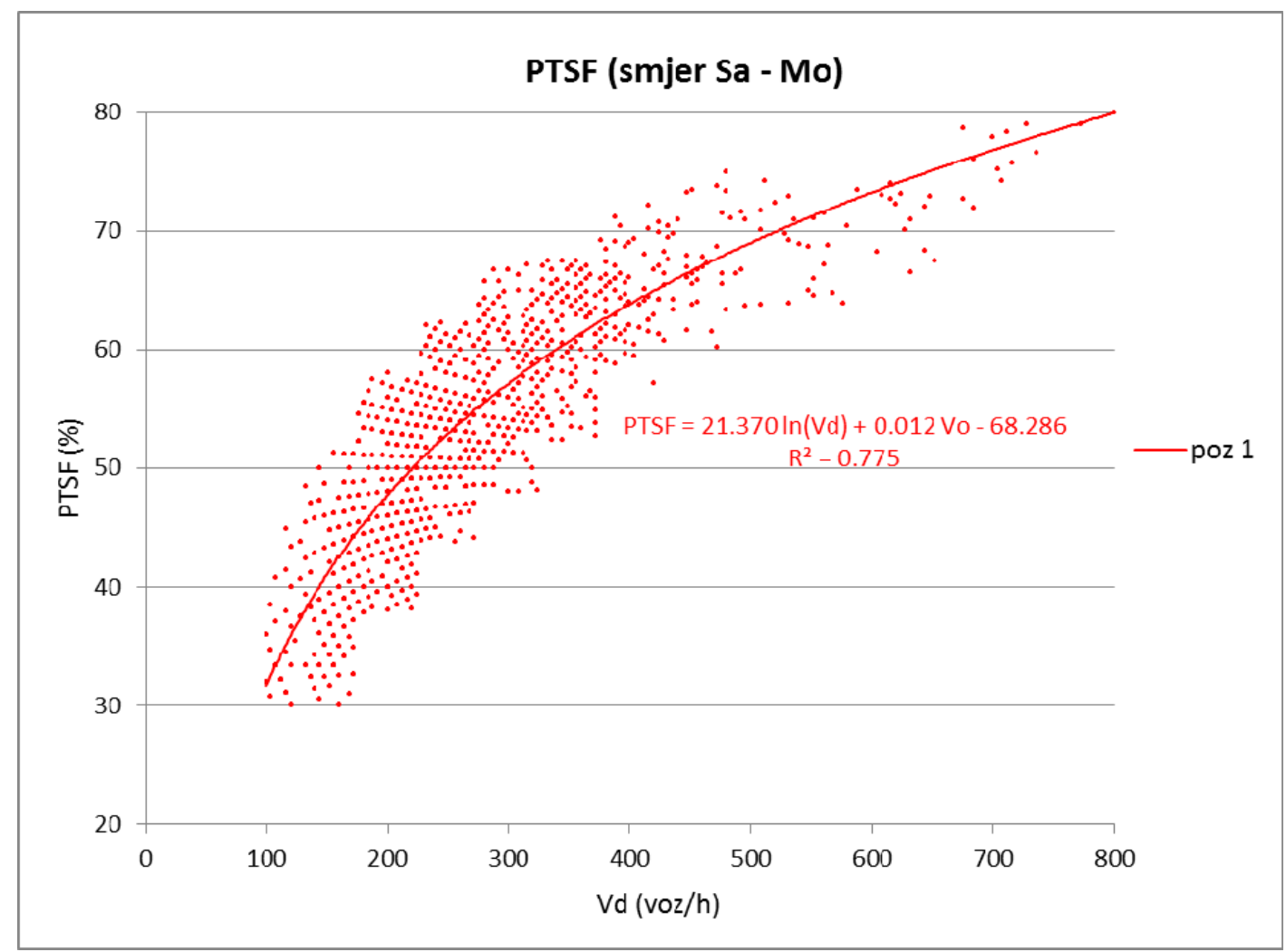

Grafikon 4.10. Rezultati mjernog mjesta 1, smjer Grabovica - Salakovac (brojilo 1) 
Na posljednjem grafikonu 4.10 prikazani su rezultati za ovaj smjer izlaznog presjeka 7 $(19+700)$.

Rezultati sa svih 7 mjernih mjesta mogu se regresijski povezati logaritamskim modelom (prikazano i na grafikonima).

Mjerno mjesto 7 (stacionaža 0+000):

$$
\operatorname{PTSF}_{7}=16.118 \cdot \ln \left(V_{d}\right)+0.002 \cdot V_{o}-42.567
$$

Mjerno mjesto 6 (stacionaža 6+650):

$$
P_{T S F}=18.057 \cdot \ln \left(V_{d}\right)+0.003 \cdot V_{o}-50.416
$$

Mjerno mjesto 5 (stacionaža 7+550):

$$
P_{T S F}=19.447 \cdot \ln \left(V_{d}\right)+0.006 \cdot V_{o}-60.630
$$

Mjerno mjesto 4 (stacionaža 10+800):

$$
\mathrm{PTSF}_{4}=20.022 \cdot \ln \left(V_{d}\right)+0.009 \cdot V_{o}-61.636
$$

Mjerno mjesto 3 (stacionaža 14+700):

$$
P T S F_{3}=19.776 \cdot \ln \left(V_{d}\right)+0.007 \cdot V_{o}-58.150
$$

Mjerno mjesto 2 (stacionaža 17+400):

$$
P_{T S F_{2}}=22.400 \cdot \ln \left(V_{d}\right)+0.012 \cdot V_{o}-77.920
$$

Mjerno mjesto 1 (stacionaža 19+700):

$$
P T S F_{1}=21.370 \cdot \ln \left(V_{d}\right)+0.012 \cdot V_{o}-68.286
$$

Analogno prvom smjeru proračunat je PTSF za smjer Grabovica - Salakovac prema izrazu:

$$
P T S F_{\text {dionice }}=19.265 \cdot \ln \left(V_{d}\right)+0,006 \cdot V_{o}-58.032
$$

\subsubsection{Snimanje zona za pretjecanje duljina $450 \mathrm{~m}$}

Nakon snimanja i analize rezultata na 7 mjernih mjesta uočene su sljedeće bitne stvari. Prva je rast PTSF-a na dijelovima dionice gdje nema pretjecanja ili postoji manji broj kraćih zona 400 - 450 m. Također je, zahvaljujući položaju mjernih mjesta (2 i 3, te 5 i 6), moguće definirati utjecaj zona za pretjecanje duljina $1100 \mathrm{~m}$ i $700 \mathrm{~m}$.

Kao što je spomenuto, uočen je vrlo mali utjecaj zona duljine $400-450 \mathrm{~m} \mathrm{u}$ odnosu na zonu duljine $700 \mathrm{~m}$, a pogotovo na zonu pretjecanja duljine $1100 \mathrm{~m}$. 
Stoga su provedena dodatna snimanja na dvije zone duljine $450 \mathrm{~m}$ kako bi se preciznije definirao utjecaj ovih zona. Snimanja su trajala 8 dana što je dalo 450 - 500 satnih opterećenja. Prva zona (između stacionaža $1+100$ i 1+550) je između mjernih mjesta 1.1 (na stacionaži 0+700) i mjernog mjesta 2 (na stacionaži 2+300). Razmak postavljenih brojila je veći od optimalnog, iz razloga nemogućnosti postavljanja brojila na povoljnije lokacije (mala preglednost i opasnost za postavljanje). Veće razlike PTSF-a su rezultat veće duljine nakupljanja vozila. Rezultati za smjer Salakovac - Grabovica prikazani su na grafikonu 4.11.

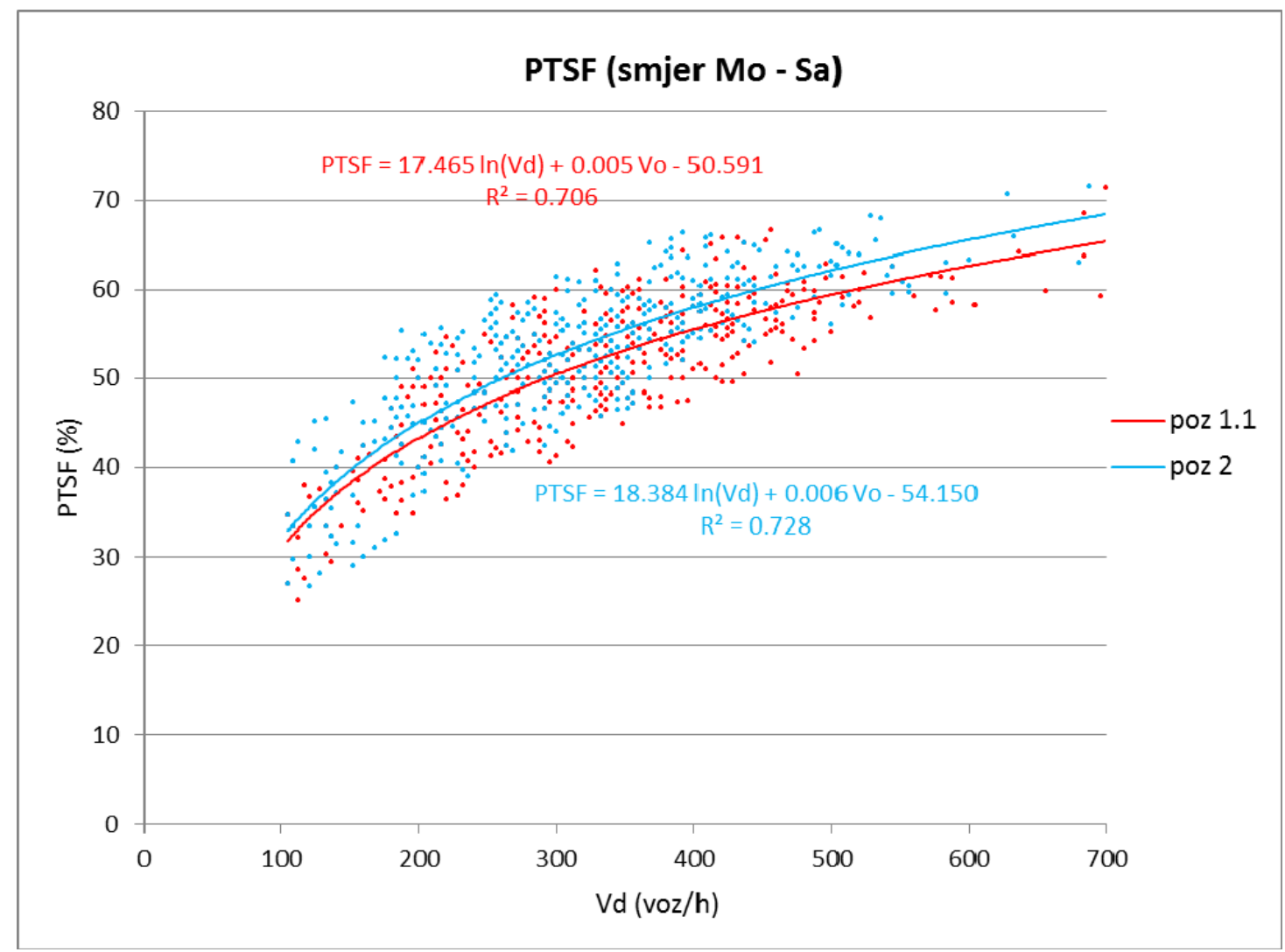

Grafikon 4.11. Rezultati zone pretjecanja na 1+100 - 1+550, smjer Salakovac - Grabovica

Za razliku od zona $1100 \mathrm{~m}$ i $700 \mathrm{~m}$, ovdje je zamjetan rast PTSF-a na drugom presjeku (poz 2 na grafikonu 4.11) u odnosu na prvi presjek (poz 1.1 na grafikonu 4.11). Utjecaj ove zone pretjecanja ipak postoji s obzirom da se razlika PTSF-ova između presjeka uvećava povećanjem prometnog opterećenja analiziranog smjera za razliku od zona duljina $1100 \mathrm{~m}$ i $700 \mathrm{~m}$ gdje se razlika smanjivala (grafikoni 4.7 i 4.9). To znači da za manja opterećenja postoji utjecaj na PTSF (postoji pretjecanje), dok se povećanjem prometnog opterećenja utjecaj zone za pretjecanja na PTSF potpuno izgubi.

Jednake zakonitosti vrijede i za suprotni smjer prikazan grafikonom 4.12. 


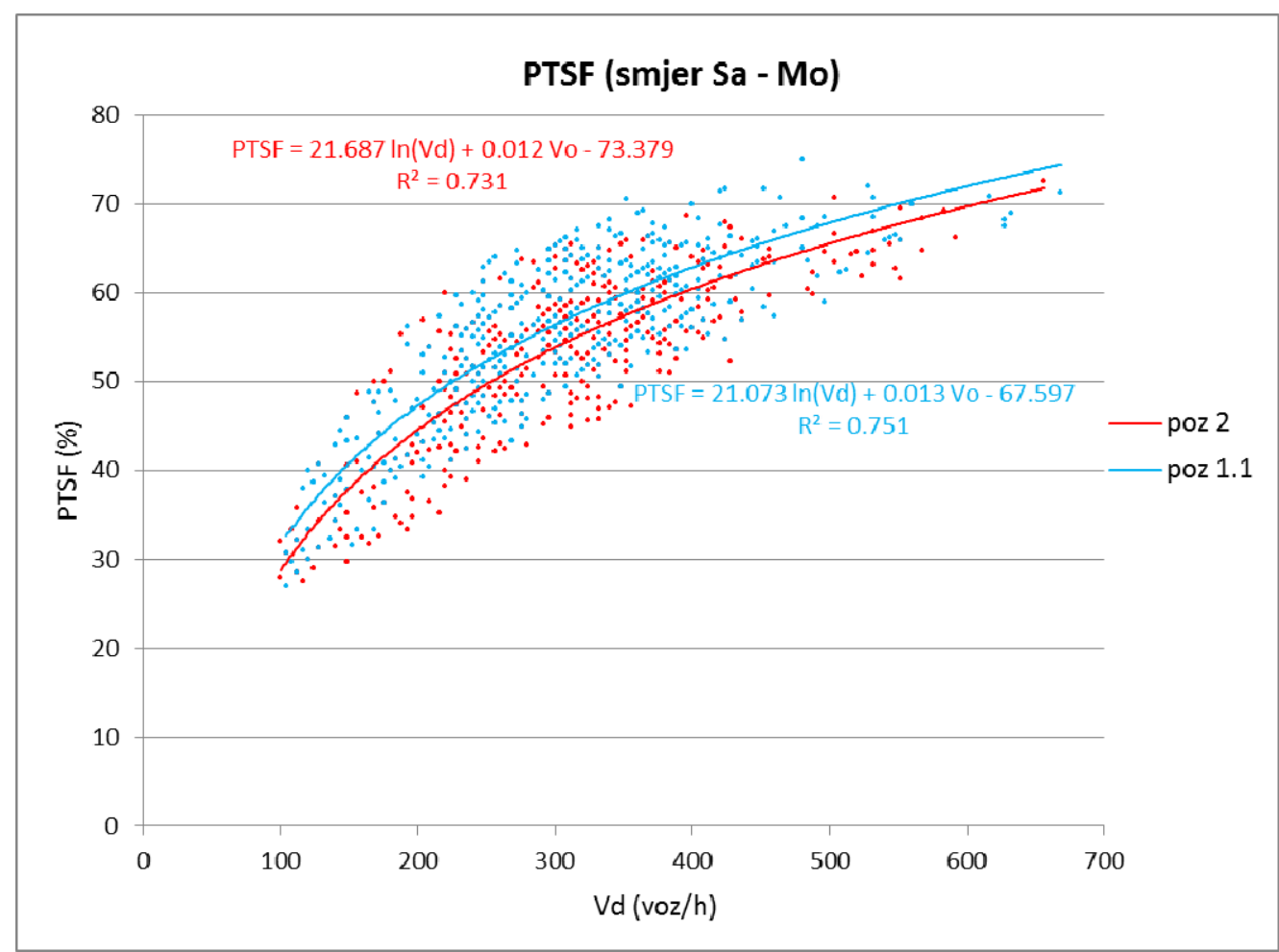

Grafikon 4.12. Rezultati zone pretjecanja na 18+150 - 18+600, smjer Grabovica - Salakovac

Druga zona $(7+100-7+550)$ nalazi se između mjernog mjesta 3.1 i i mjernog mjesta 3.2 (6+900 i 7+700). Lokacije postavljenih brojila su bile puno povoljnije jer su se nalazile na $200 \mathrm{~m}$ prije i $150 \mathrm{~m}$ poslije zona pretjecanja. Time se izravnije dobio utjecaj ove zone jer se smanjilo nakupljanje vozila i povećanje PTSF-a.

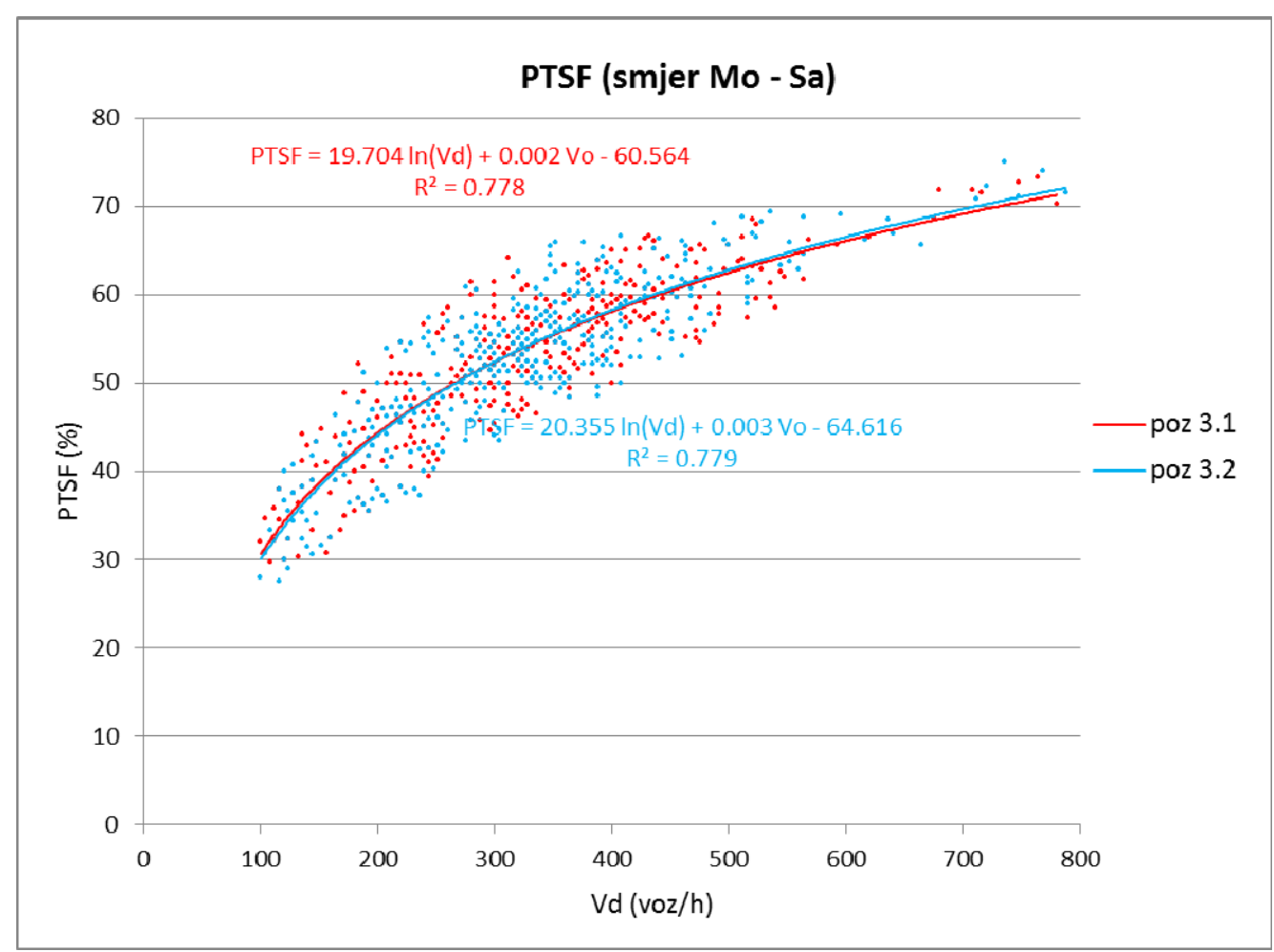

Grafikon 4.13. Rezultati zone pretjecanja na 7+100 - 7+550, smjer Salakovac - Grabovica 
Na grafikonu 4.13 prikazani su rezultati ove zone i može se vidjeti gotovo preklapanje krivulja, što znači da je promjena PTSF-a vrlo mala. Zakonitosti su jednake kao na prethodnoj zoni, samo je manja promjena razlike PTSF-a rezultat manjeg razmaka mjernih mjesta.

Analiza suprotnog smjera daje jednake zakonitosti (grafikon 4.14).

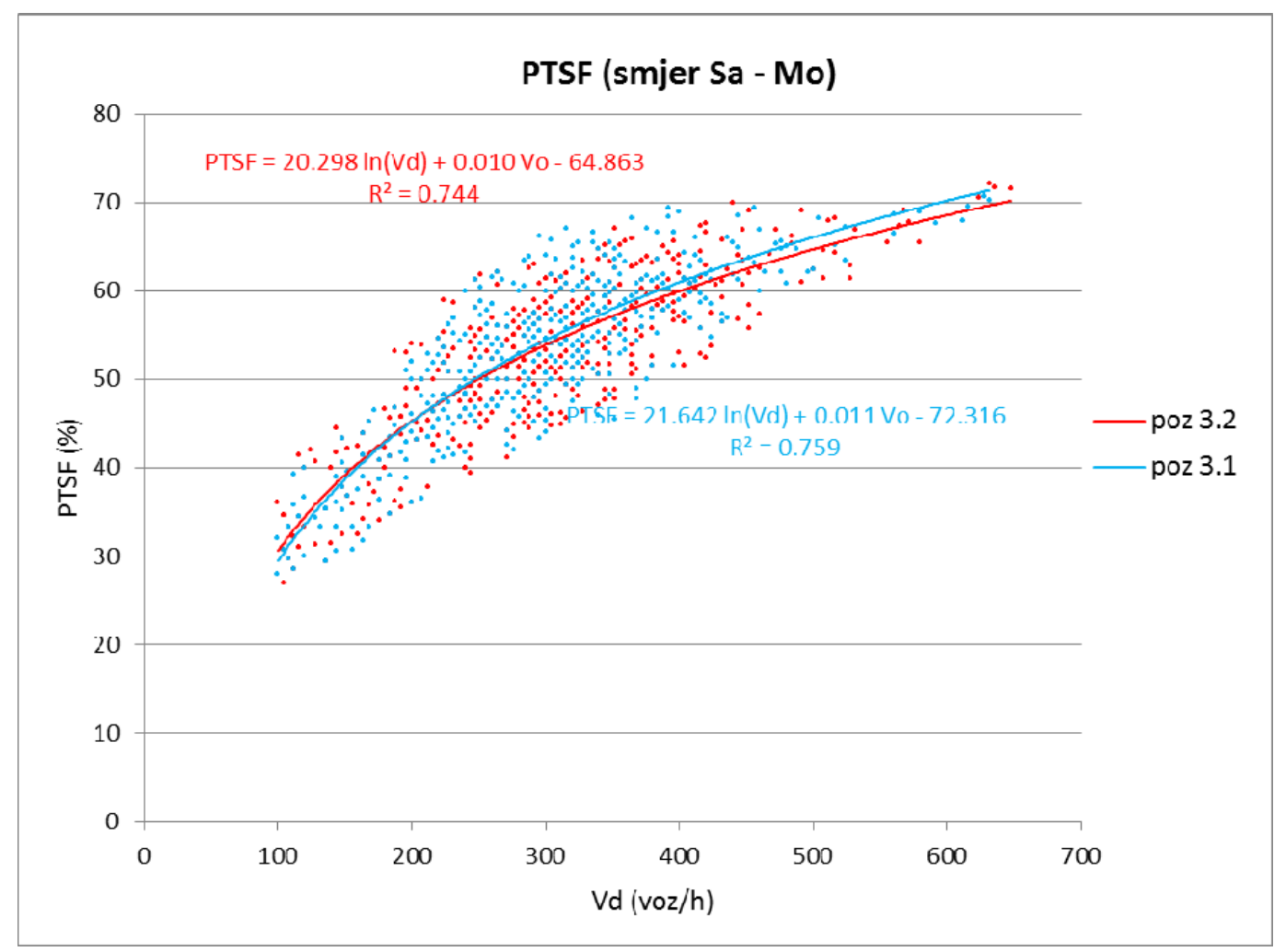

Grafikon 4.14. Rezultati zone pretjecanja na $12+150-12+600$, smjer Grabovica - Salakovac

Na temelju analize rezultata provedenih istraživanja može se zaključiti da je duljina zona za pretjecanje bitan faktor za određivanje PTSF-a dionice, a ne samo ukupan postotak tih zona na dionici (u HCM-u postotak zona bez pretjecanja NPZ). Dobivenim podacima je potvrđen uočeni mali utjecaj kratkih zona za pretjecanje, za razliku od utjecaja zona za pretjecanje duljina $1100 \mathrm{~m}$ i $700 \mathrm{~m}$. Utjecaj kratkih zona (zone duljine 400 - $450 \mathrm{~m}$ ) za pretjecanje na PTSF u odnosu na dulje zone (1100 m i 700 m) višestruko je manji nego je odnos duljina zona za pretjecanje.

\subsection{Usporedba dobivenih rezultata s HCM metodologijom}

U prethodnim podpoglavljima su prezentirani rezultati dobiveni terenskim istraživanjima za oba smjera. Nakon obrade terenskih rezultata, dobivene su vrijednosti PTSF-a preko regresijskih krivulja za različite vrijednosti opterećenja analiziranog i suprotnog toka po 
navedenim presjecima i sumarno za cijelu dionicu. Također su urađeni proračuni prema HCM 2010 za ista opterećenja i postotak zona bez pretjecanja (70 \%) kao i na analiziranoj dionici. Za proračun prema HCM 2010 uvršteno je 10 \% teretnih vozila što je prosjek utvrđen i na analiziranoj dionici. S obzirom da je utjecaj udjela teretnih vozila na PTSF zanemariv, $u$ nastavku su analizirani tok $V_{d}$ i suprotni tok $V_{o}$ izraženi su $u$ voz/h. Rezultati su prikazani $u$ tablici 4.1 i na grafikonu 4.15 .

Tablica 4.1. Rezultati dobiveni regresijskim izrazima i proračunom prema HCM 2010 (distribucija 50/50)

\begin{tabular}{|c|c|c|c|c|c|}
\hline $\begin{array}{c}\mathbf{V}_{\mathbf{d}}=\mathbf{V}_{\mathbf{o}} \\
(\mathbf{v o z} / \mathbf{h})\end{array}$ & $\begin{array}{c}\text { HCM } \\
\mathbf{2 0 1 0}\end{array}$ & smjer 1 & $\begin{array}{c}\text { Razlika HCM 2010 } \\
\text { i smjera 1 (\%) }\end{array}$ & smjer 2 & $\begin{array}{c}\text { Razlika HCM 2010 } \\
\text { i smjera 2 (\%) }\end{array}$ \\
\hline 200 & 52.80 & 43.41 & +21.63 & 45.36 & +16.40 \\
\hline 300 & 60.20 & 52.26 & +15.19 & 53.83 & +11.83 \\
\hline 400 & 64.80 & 58.72 & +10.35 & 60.04 & +7.93 \\
\hline 500 & 69.90 & 63.86 & +9.46 & 64.99 & +7.56 \\
\hline 600 & 74.20 & 68.18 & +8.83 & 69.17 & +7.27 \\
\hline 700 & 77.90 & 71.92 & +8.31 & 72.80 & +7.01 \\
\hline
\end{tabular}

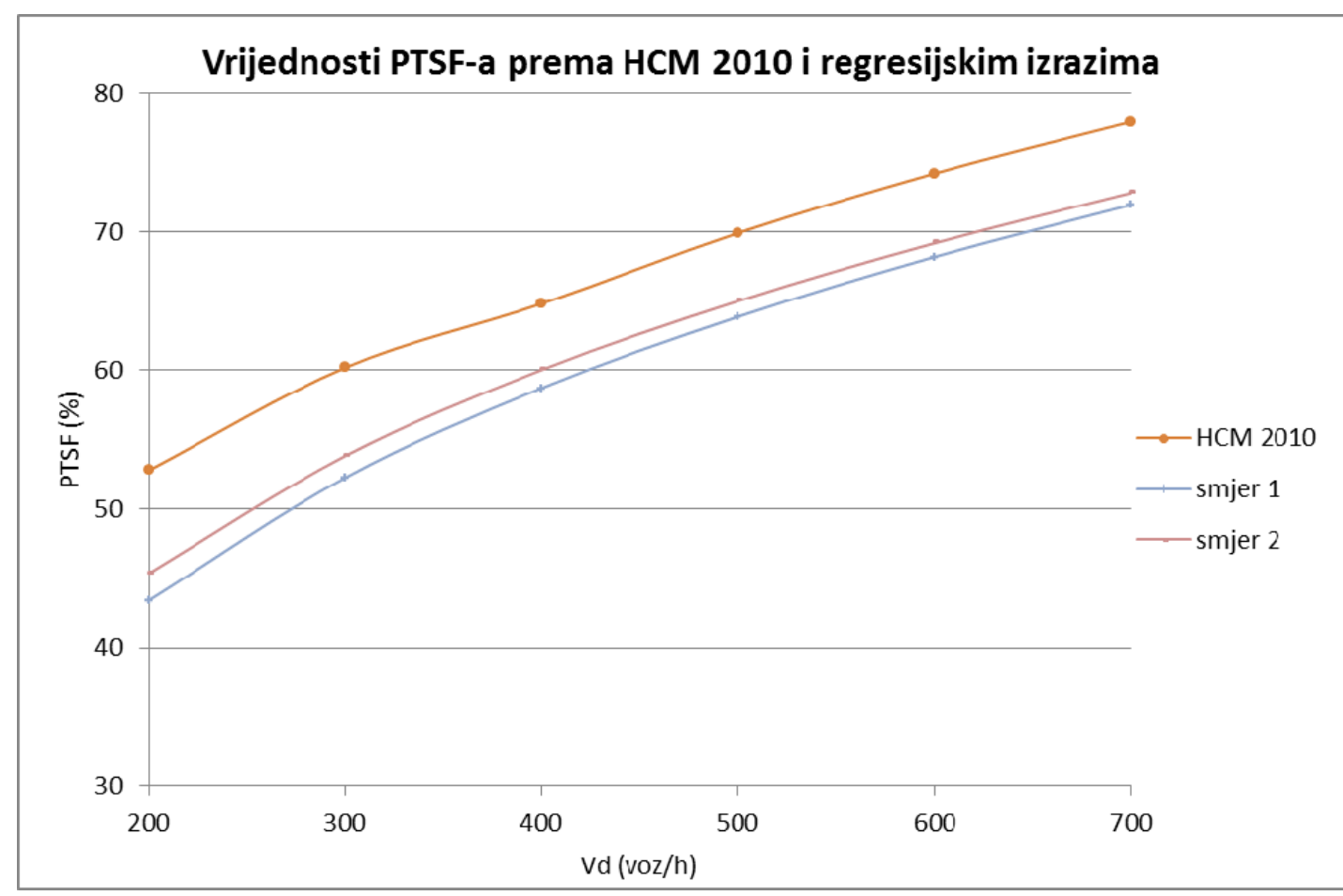

Grafikon 4.15. Rezultati dobiveni regresijskim izrazima i proračunom prema HCM 2010 (distribucija 50/50) 


\subsection{Nedostaci primjene HCM metodologije}

Već je ranije spomenuto da HCM metodologija nije prilagođena uvjetima u $\mathrm{BiH}$ jer pretpostavlja velike brzine za predmetnu kategoriju ceste koje se zbog terenskih uvjeta ne mogu postići, kao i to da je PTSF znatno veći nego je slučaj na terenu. Više je razloga za to, a njihova analiza dana je u nastavku.

\subsubsection{Proračun PTSF-a preko BPTSF-a}

BPTSF predstavlja ,idealnu“ dionicu za mogućnost pretjecanja $100 \%$ na cijeloj dionici (opisan u 2. poglavlju). Većina dionica dvotračne izvangradske mreže ima mogućnost pretjecanja u najboljem slučaju 25 - $30 \%$, a dobar dio njih oko $15 \%$. Stoga, BPTSF kao takav nije prikladan kao početni parametar jer je teško mjerljiv na terenu. Jednostavniji pristup je početi od proračuna maksimalnog PTSF-a koji bi se odnosio na dionicu gdje nema pretjecanja (što je lako terenski izmjeriti) te se utvrđena vrijednost umanjuje s obzirom na utjecaj duljina zona pretjecanja. To je u suprotnosti s HCM pristupom (od idealnih do prevladavajućih uvjeta), ali bi na ovaj način „korekcijski faktori“ bili znatno manji i precizniji ( $f_{n p}$ je u proračunima često veći od BPTSF-a).

\subsubsection{Distribucija brzina i udio teških vozila}

U HCM metodologiji [T.1, T.2] brzina ne utječe značajno na vrijednost PTSF-a, a i osjetljivost na udio teških vozila (\%HV) je vrlo mala. Zanemariv utjecaj teških vozila je dobiven i na terenu, što je u skladu i s nekim ranijim istraživanjima [L.1, L.2]. S druge strane, računska brzina ima znatno veći utjecaj iz razloga što ona definira odvijanje samog prometnog toka i postoje razlike na cestama gdje je računska brzina npr. $100 \mathrm{~km} / \mathrm{h}$ i $80 \mathrm{~km} / \mathrm{h}$, što su pokazala i neka istraživanja [L.1, L.2]. Druga bitna činjenica je sama distribucija brzina, prije svega, željenih brzina jer one definiraju interakciju vozila i zadržavanje u koloni.

\subsubsection{Utjecaj suprotnog toka na PTSF analiziranog toka}

Veličina suprotnog toka $\left(\mathrm{V}_{\mathrm{o}}\right)$ daje drugačije rezultate PTSF-a na terenu od HCM 2010. Prema HCM 2010 vrijednost PTSF-a analiziranog smjera $\left(\mathrm{V}_{\mathrm{d}}\right)$ opada povećanjem veličine suprotnog toka $V_{o}$, osim u pojedinim slučajevima za suprotni tok manji od $300 \mathrm{voz} / \mathrm{h}$ (grafikon 4.16).

Također, HCM 2010 daje promjenu PTSF-a analiziranog smjera i za slučaj bez ikakvog pretjecanja (100\% NPZ), što nije logično jer tada suprotni tok nema nikakvog utjecaja (nema interakcije smjerova). 


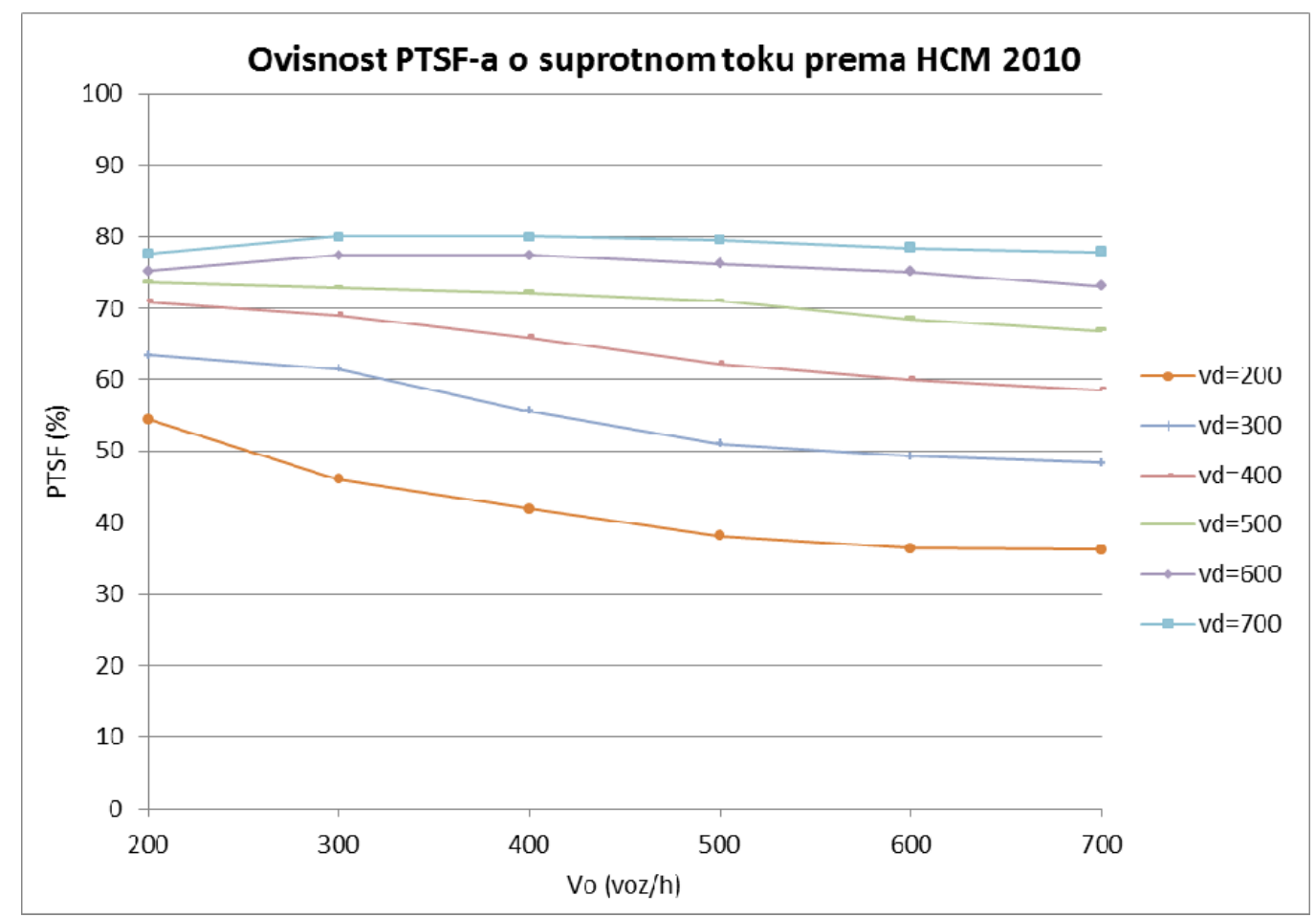

Grafikon 4.16. PTSF ovisno o suprotnom toku prema HCM 2010 za 70 \% NPZ

Rezultati dobiveni na terenu za cijelu dionicu pokazuju rast PTSF-a za povećanje suprotnog toka $\mathrm{V}_{\mathrm{o}}$. Grafikon 4.17 prikazuje međuovisnost analiziranog $\mathrm{V}_{\mathrm{d}}$ i suprotnog toka $\mathrm{V}_{\mathrm{o}}$ na cijeloj dionici u smjeru 1 (Salakovac - Grabovica), a ista je analogija i za suprotni smjer.

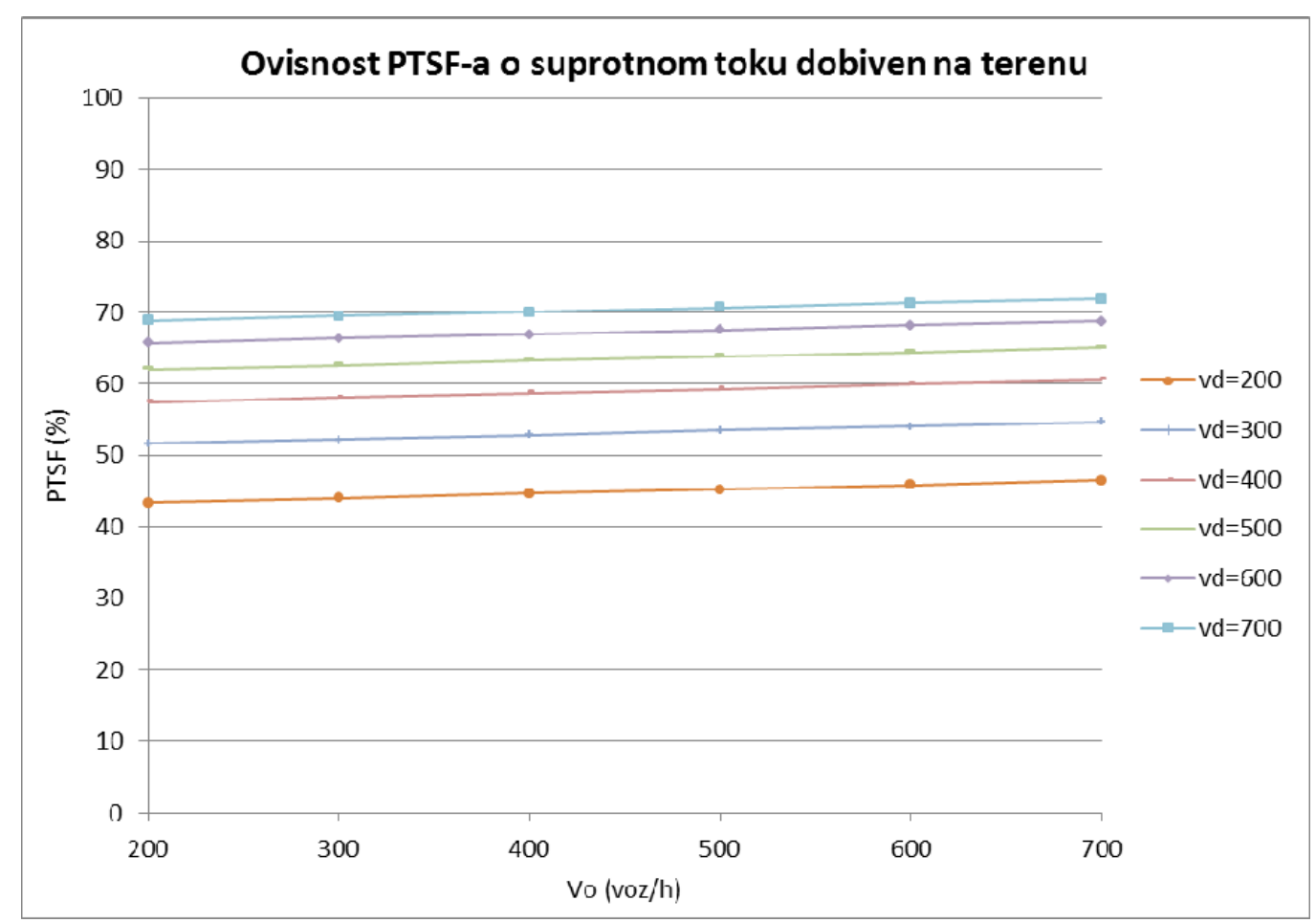

Grafikon 4.17. PTSF ovisno o suprotnom toku za cijelu dionicu, smjer Salakovac - Grabovica 


\subsubsection{Utjecaj No-Passing zona na PTSF}

HCM 2010 za proračun PTSF-a uzima postotak zona bez pretjecanja (NPZ), ne uzimajući u obzir njihov broj i duljinu. Također, za područje vrijednosti NPZ-a od $60-100 \%$ razlike u vrijednostima su vrlo male (grafikon 4.18).

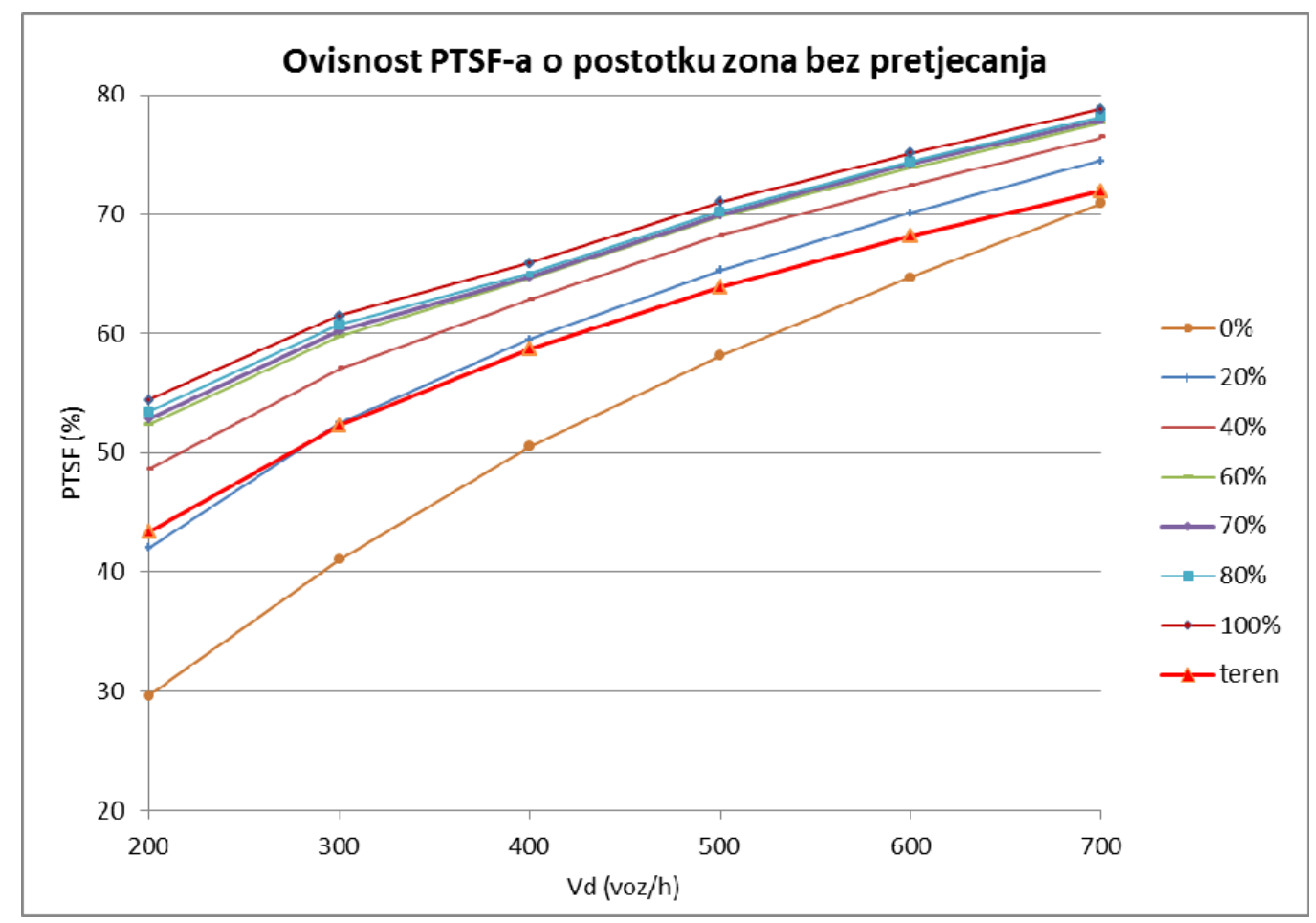

Grafikon 4.18. PTSF prema HCM 2010, ovisno o NPZ-u za distribuciju po smjeru 50/50

To praktično znači da je zanemariva razlika u vrijednosti PTSF-a između dionica bez pretjecanja (100\% NPZ) i dionice kakva je predmetna (70\% NPZ). Ovo ne odgovara rezultatima s terena, osobito za mala opterećenja koja omogućuju veći broj pretjecanja. Kako je većina cesta u $\mathrm{BiH}$ u području 70 - 100 \% HCM ne može rezultirati pouzdanim procjenama PTSF-a.

\subsubsection{Duljina i broj pojedinih zona pretjecanja}

Kao što je prethodno spomenuto, HCM 2010 ne uzima u obzir duljinu i broj pojedinih zona pretjecanja.

Rezultati terenskih istraživanja pokazuju da duljina zona pretjecanja ima značajnu ulogu, što je slično i nekim ranijim istraživanjima [M.2]. U poglavlju 4.1 prikazani su rezultati utjecaja zona $1100 \mathrm{~m}, 700 \mathrm{~m}$ i dviju dionica po $450 \mathrm{~m}$. Može se vidjeti da je mnogo veći utjecaj na PTSF zone za pretjecanje $1100 \mathrm{~m}$ od one $700 \mathrm{~m}$, nego što je odnos njihovih u duljina. Kratke zone (400 - 450 m) imaju vrlo mali utjecaj za manja opterećenja, dok za veća gotovo da nemaju utjecaja. 


\subsection{Usporedba rezultata istraživanja s drugim modelima}

Nakon usporedbe s HCM 2010, rezultati istraživanja su u nastavku uspoređeni s drugim poznatim modelima opisanim u poglavlju 2. Izračunat je PTSF za $70 \%$ zona bez pretjecanja (kao što je i predmetna dionica) te $10 \%$ teških teretnih vozila (prosjek i na anliziranoj dionici) za modele koji sadrže ovaj parametar (tablica 4.2 i grafikon 4.19). $\mathrm{S}$ obzirom da su modeli $\mathrm{u}$ poglavlju 2 detaljno opisani, u nastavku će biti dat samo osvrt na rezultate ovih modela.

Tablica 4.2. PTSF prema rezultatima istraživanja i drugim modelima ( 70 NPZ, distr. 50/50)

\begin{tabular}{|c|c|c|c|c|c|c|}
\hline $\mathbf{V}_{\mathbf{d}}=\mathbf{V}_{\mathbf{0}}$ & HCM 2010 & $\begin{array}{c}\text { Luttinen, } \\
\mathbf{2 0 0 1 .}\end{array}$ & $\begin{array}{c}\text { Al-Kaisy i } \\
\text { Durbin, } \\
\mathbf{2 0 0 8 .}\end{array}$ & $\begin{array}{c}\text { Polus i } \\
\text { Cohen, } \\
\mathbf{2 0 0 9} .\end{array}$ & $\begin{array}{c}\text { Moreno i } \\
\text { drugi } \\
\mathbf{2 0 1 4} .\end{array}$ & $\begin{array}{c}\text { Teren, } \\
\mathbf{2 0 1 7 .}\end{array}$ \\
\hline 200 & 52.80 & 33.01 & 35.97 & 18.26 & 34.87 & 43.41 \\
\hline 300 & 60.20 & 43.65 & 42.55 & 26.10 & 44.78 & 52.26 \\
\hline 400 & 64.80 & 52.40 & 49.13 & 33.18 & 51.81 & 58.72 \\
\hline 500 & 69.90 & 59.62 & 55.72 & 39.59 & 57.26 & 63.86 \\
\hline 600 & 74.20 & 66.07 & 62.30 & 45.38 & 61.71 & 68.18 \\
\hline 700 & 77.90 & 71.03 & 68.88 & 50.62 & 65.48 & 71.92 \\
\hline
\end{tabular}

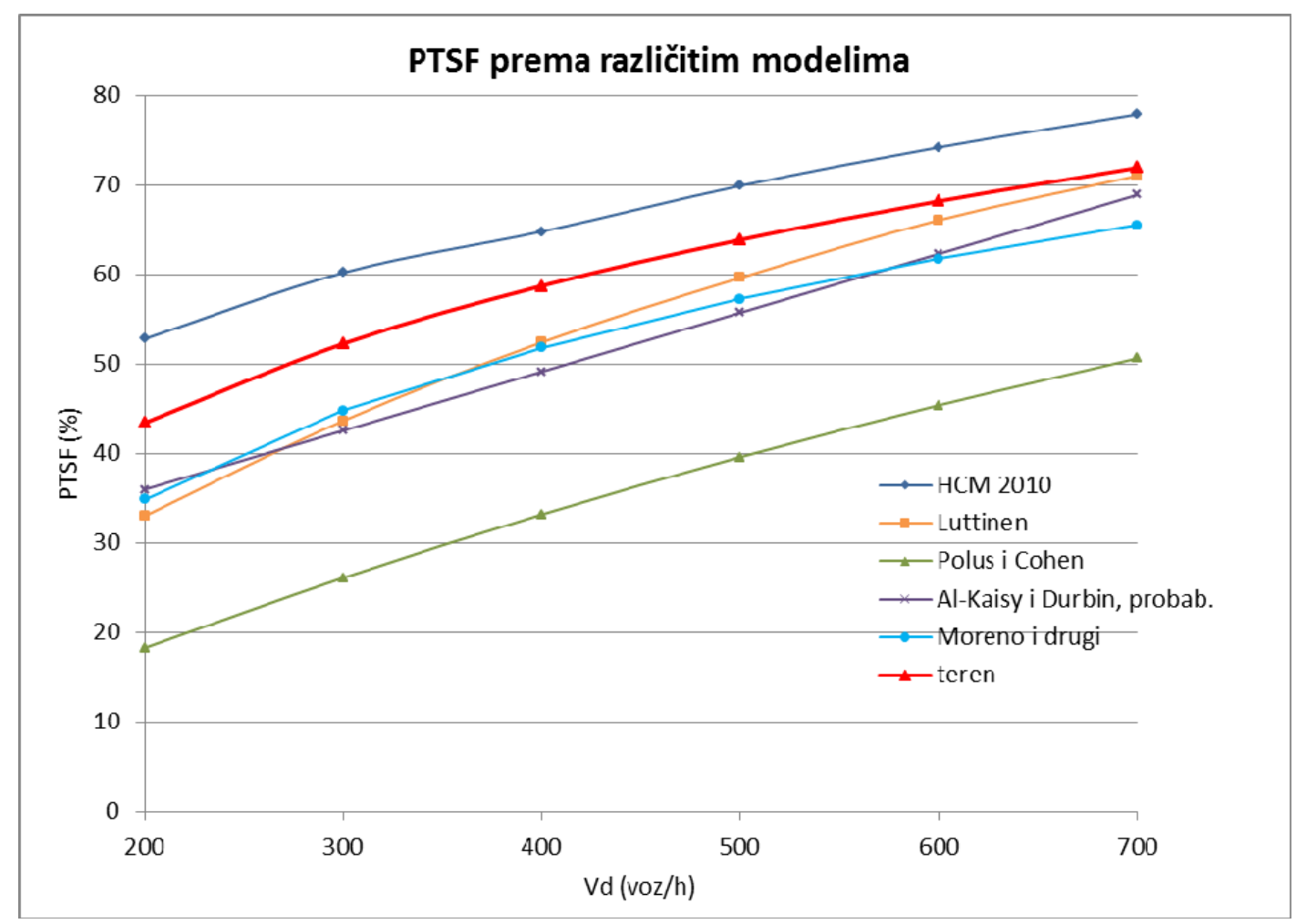

Grafikon 4.19. PTSF prema rezultatima istraživanja i drugim modelima (70 NPZ, distribucija $50 / 50)$ 
Iz rezultata se može vidjeti da Polusov i Cohenov model [P.2] daje iznimno niske vrijednosti u odnosu na sve druge modele. Također, HCM 2010 [T.2] model daje uvjerljivo najveće vrijednosti, dok ostala 3 modela daju nešto niže vrijednosti od onih dobivenih na terenu.

Razlog najvećih vrijednosti HCM-ovog modela leži u neprilagođenosti lokalnim uvjetima te, kako je već naglašeno, nepouzdanosti modela za velike postotke NPZ-a (od 70 do $100 \%$ ), kakvi prevladavaju u BiH uvjetima (grafikon 18).

Izraelski (Polus i Cohen) [P.2] i španjolski model (Moreno i drugi) [M.2] kao parametar imaju samo ukupno prometno opterećenje te opterećenje analiziranog smjera. Prvi [P.2] je dobiven na osnovu analize kolona prema teoriji repova i prilagođen lokalnim uvjetima. S obzirom na novi pristup i kompleksnost teško je primjenjiv za BiH prilike. Drugi model [M.2] predstavlja regresiju na terenu izmjerenih vrijednosti PTSF-a, što također ne odgovara prevladavajućim prometnim uvjetima u $\mathrm{BiH}$.

Luttinenov model (za brzinu $80 \mathrm{~km} / \mathrm{h}$ ) [L.1] je najkompletniji i sadrži najviše parametara. Ono što ga karakterizira je vrlo mala osjetljivost PTSF-a za velike postotke zona bez pretjecanja, kao i kod HCM-a, zbog čega također nije prikladan za primjenu u BiH uvjetima.

Model koji su definirali Al-Kaisy i Durbin (probabilistički) [A.3] pokazuje vrlo veliku osjetljivost i na teška vozila (HV), a također i na postotak zona bez pretjecanja. Osim probabilističkog pristupa, problem primjene u BiH predstavlja i primjena brzine kao značajnog parametra u modelu, a za koju je više puta naglašeno da nije prikladan parametar za prometne prilike u $\mathrm{BiH}$.

Na temelju rezultata i prethodno iznešenog, može se zaključiti da su ovi modeli vrlo teško primjenjivi za BiH uvjete. 


\section{SIMULACIJSKI SOFTWARE VISSIM 9 I KALIBRACIJA MODELA}

U uvodnom poglavlju već je iznešena važnost primjene simulacijkih softwarea. Kao glavni razlog navedena je mogućnost simuliranja različitih prometnih uvjeta koje je nemoguće obuhvatiti snimanjem na terenu, te stvaranje novih prometnih uvjeta kojih nema na terenu (promjene duljina zona za pretjecanje). Da bi se software mogao koristiti za simulacije potrebno ga je najprije kalibrirati i validirati na temelju provedenih terenskih istraživanja.

U ovoj disertaciji korišten je VISSIM 9 (proizvod njemačke tvrtke PTV Karlsruhe) [P.6] iz razloga što je jedan od vodećih mikroskopskih simulacijskih softwarea u svijetu. U nastavku je najprije opisan simulacijski software Vissim 9, a zatim kalibracija i validacija istog na temelju rezultata provedenih terenskih istraživanja. Opis Vissima preuzet je iz mariborskog udžbenika „Mikrosimulacije u prometu (radni udžbenik s primjenom VISSIM-a)“ iz 2014. godine [Š.1].

S obzirom na to da Vissim 9 nema mogućnost direktnog dobivanja PTSF-a, vrijednosti PTSF-a su dobivane preko vremena prolazaka vozila u zadanim presjecima. Definirani su presjeci (data collection points) svakih $250 \mathrm{~m}$ i na njima se registriraju vremena prolaska svakog vozila po smjeru. $\mathrm{Na}$ temelju razlike vremena prolazaka uzastopnih vozila dobiju se vremena slijeda svakog pojedinog vozila što omogućuje određivanje PTSF-a. Prosječna vrijednost PTSF-a svih presjeka (svakih $250 \mathrm{~m}$ ) predstavlja PTSF dionice.

\subsection{Simulacijski software Vissim 9}

Vissim omogućuje simulacije širokog spektra prometnih tokova, s naglaskom na analizu i optimizaciju istih. Predstavlja stohastički (slučajni), diskretni (izdvajanje samo onih vremenskih intervala gdje su zabilježene promjene) i vremenski prilagođen model. Model rabi model slijeda vozila (Car Following Model) koji se temelji na Wiedemannovoj teoriji prometnog toka [L.6, W.3, W.4] gdje su vrijeme reakcije "vozača", brzina i ubrzanje prilagođeno svakom pojedinom vozaču (vozilu). Sastoji se od nekoliko podmodela koji su opisani u nastavku.

\subsubsection{Model slijeda vozila (Car Following model)}

Osnovni princip modela temelji se na "imitiranju" konkretnih reakcija i odluka koje donosi vozač kada vozi iza drugog vozila. Kad vozač dostigne vozilo ispred sebe on počne kočiti u trenutku svog praga zamjećivanja sporijeg vozila ispred sebe. Kako nije u mogućnosti odrediti 
točnu brzinu vozila ispred sebe, prilagođena brzina će biti niža od brzine vozila ispred njega. Zatim vozač počne ponovno ubrzavati vozilo dok ne postigne sljedeći prag zamjećivanja. Proces se iterativno nastavlja s izmjenom ubrzavanja i kočenja (slika 5.1).

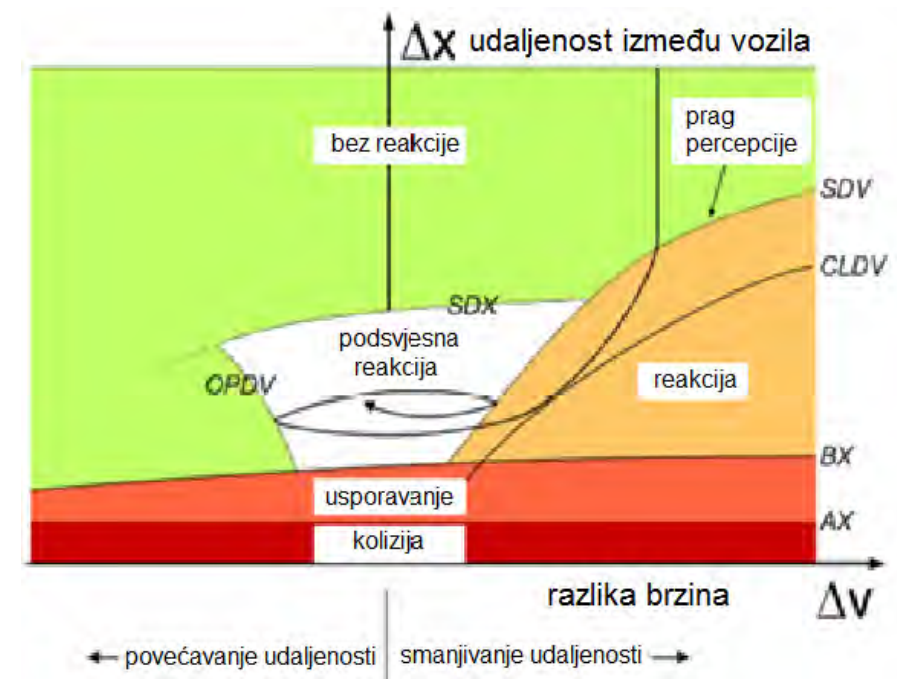

Slika 5.1. Psihofizički model slijeda vozila prema Wiedemannu [Š.1]

Prema ovom modelu vozač se nalazi u jednoj od četiri situacije:

- Vožnja u slobodnom prometnom toku: Vozač vozi bez utjecaja ostalih vozila i teži postići željenu brzinu putovanja.

- Približavanje: Vozač prilagođava brzinu vožnje sporijem vozilu ispred sebe (kočenjem) s namjerom da razlika u brzini bude nula u trenutku kad ostvari (za njega) primjeren sigurnosni razmak.

- Slijeđenje: Vozač slijedi vozilo ispred sebe i zbog premalo preciznog dodavanja i oduzimanja gasa dolazi do vrlo malih promjena brzine.

- Kočenje: To je proces srednjih ili većih usporavanja, ukoliko sigurnosni razmak između vozila padne ispod granične vrijednosti. Drugu mogućnost predstavlja iznenadno kočenje vozača u vozilu ispred i/ili ukoliko se vozilo iz susjednog prometnog traka "prepliće" (mijenja prometni trak).

Za simulacije se može odabrati jedan od dva Wiedemannova modela slijeda vozila (Car Following Model):

- Wiedemann 74 koji je prilagođen za ceste u naselju

- Wiedemann 99 koji prilagođen za ceste izvan naselja i autoceste (osim za područja preplitanja i uključivanja)

Može se i isključiti model slijeda za jednostavne simulacije (npr. pješaka).

Kako se radi o analizi dvotračnih izvangradskih cesta, ovdje se koristio Wiedemann 99 model. Parametri ovog modela su (slika 5.2):

- $C C O=$ propisani željeni razmak između zaustavljenih vozila (nepromjenjiv). 
- CC1 = željeno vrijeme slijeda. Na temelju CC1 (pomnožen s brzinom vožnje v $(\mathrm{m} / \mathrm{s})$ ) definira se sigurnosni razmak dx_safe (m) koji predstavlja minimalni razmak između dvaju vozila i ovisi o vozaču. Bitno utječe na kapacitet prometnog toka i na sigurnost:

$$
d x_{-} \text {safe }=C C O+C C 1 \cdot v
$$

- $C C 2$ = promjenjivi razmak slijeda. Jednak je dx_safe, a može se povećati (ovisi o vozaču), npr. dx_safe $+10 \mathrm{~m}$.

- CC3 = parametar koji nadzire kočenje vozila u slijedu koje se događa kada vozač zamijeti da je vozilo ispred njega sporije i na vrijeme počne kočiti (za vozača je to sigurnosni razmak).

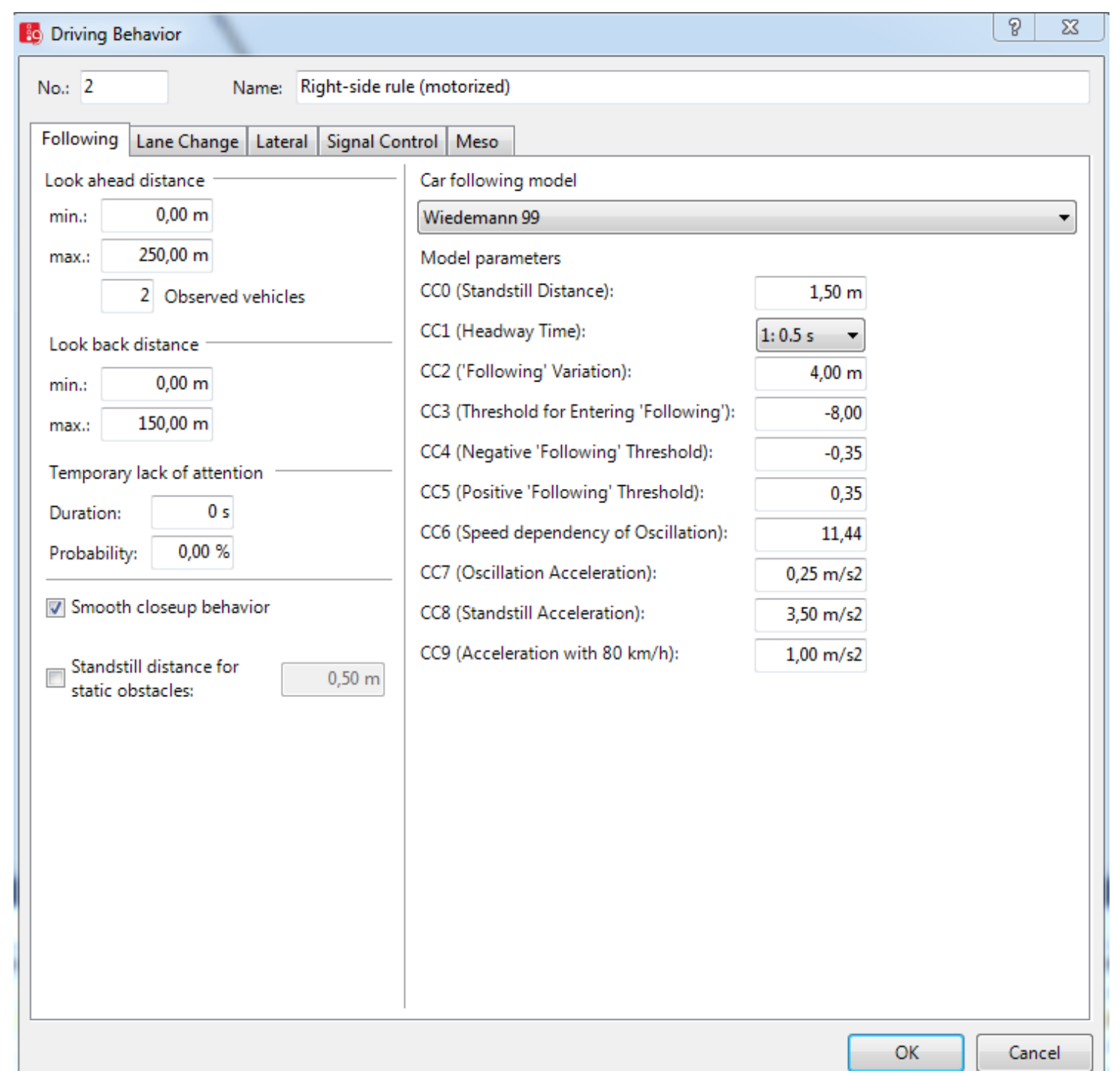

Slika 5.2. Psihofizički parametri modela Wiedemann 99 [P.6]

- CC4 i CC5 = sigurnosni parametri slijeda koji se mogu prilagoditi na odgovarajuću graničnu vrijednost (reagiraju u slučaju prekoračenja).

- CC6 = predstavlja oscilaciju brzine kod slijeda. Ako parametar iznosi 0, nema oscilacije brzine, dok veći parametri znače veće oscilacije. 
- CC7 = predstavlja oscilaciju ubrzanja.

- CC8 = predstavlja ubrzanje kod starta vozila iz stanja mirovanja.

- CC9 = ubrzanje vozila koja voze $80 \mathrm{~km} / \mathrm{h}$. Ograničen je krivuljama ubrzanja.

\subsubsection{Model promjene prometnog traka}

Kod mijenjanja prometnog traka, model Wiedemann 99 prati brzinu vozila koje mijenja prometni trak i vozila za njim te omogućuje promjenu traka lijevo i desno.

Promjena prometnog traka (prestrojavanje) odvija se na dva načina (slika 5.3):

1. potrebno (nužno) mijenjanje traka (kako bismo vozilo "doveli" na željenu cestu)

2. slobodno mijenjanje traka (zbog postizanja veće brzine na manje zauzetom prometnom traku).

U slučaju"potrebne promjene prometnog traka" u parametrima ponašanja vozača uključene su maksimalno prihvatljiva usporenja vozila.

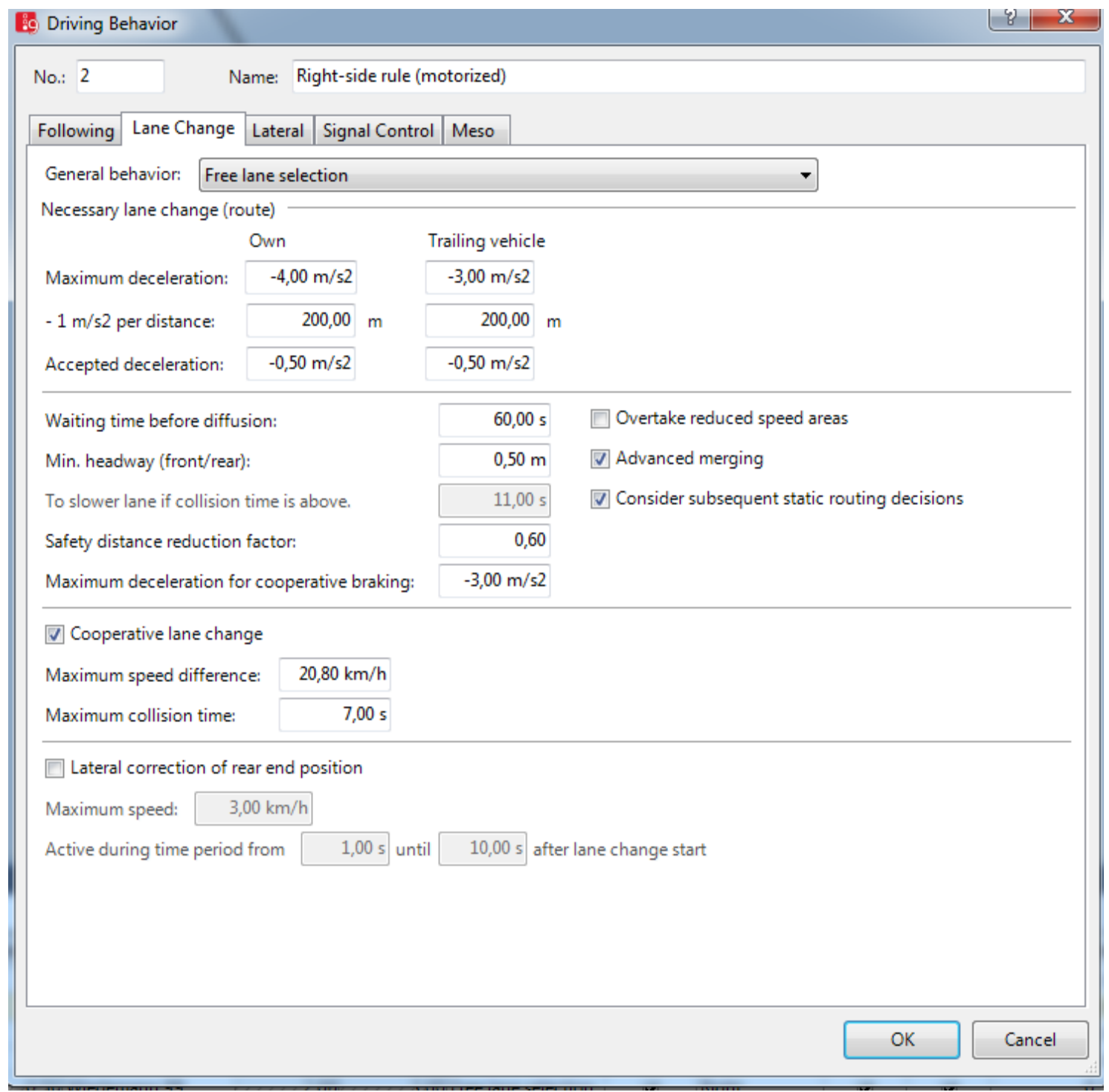

Slika 5.3. Parametri promjene prometnog traka [P.6] 
U slučaju "slobodnog mijenjanja prometnog traka" simulacijski program "provjerava" sigurnosni razmak vozila (u susjednom traku) iza vozača koji se prestrojava. Taj sigurnosni razmak ovisi o brzini promatranog vozila i brzini vozila koje se prestrojava.

Kad vozač želi promijeniti prometni trak provjerava se odgovarajuće "vrijeme slijeda" (Headway) na ciljnom prometnom traku. Vremenska praznina ovisi o brzini vozila koje se prestrojava i vozila koje dolazi na ciljnom prometnom traku. Potrebno prestrojavanje vozila također ovisi o veličini usporenja, odnosno "agresivnosti" vozača drugog vozila. Parametari maksimalno usporenje vozila koje mijenja prometni trak (Own) i vozila koje je na ciljnom prometnom traku (Trailing) određeni su "maksimalnim usporenjem" (Maximum Decelerations) i „prihvatljivim usporenjem“ (Accepted Decelerations). Moguće je dodatno prilagoditi i takozvani "redukcijski faktor" (-1m/s $\mathrm{s}^{2}$ per distance) koji smanjuje maksimalnu vrijednost usporenja, s povećavanjem udaljenosti do trenutačnog zaustavljanja.

Funkcija "vrijeme čekanja prije uklanjanja vozila iz simulacije" (Waiting Time Before Diffusion) određuje koliko će vozilo uz "punu liniju" čekati na promjenu prometnog traka (traženje prikladne praznine), dok simulacija automatski ne ukloni vozila iz procesa. To je vrlo korisna funkcija kad se zbog "neaktivnosti" jednog vozila "zablokira" simulacija. U tom slučaju se na kraju simulacije pojavi poruka "ErrorMessage".

Također je moguće odrediti "minimalni razmak ispred" (Min. Headway) u odnosu na vozilo u mirovanju na susjednom traku i "faktor redukcije sigurnosnog razmaka" (Safety Distance Reduction Factor). Primjerice, vrijednost faktora 0.6 smanjuje sigurnosni razmak za 40 \%. Kad vozilo promijeni prometni trak, sigurnosni razmak ovo vozilo ponovno se postavi na zadanu (Default) vrijednost.

Vrijednost parametra "maksimalnog usporenja za kooperativno kočenje" (Maximum Deceleration for Cooperative Braking) predstavlja prihvatljivo usporenje vozila na susjednom prometnom traku s namjerom da "propusti" ispred sebe vozilo koje se prestrojava. Ukoliko želimo modelirati ograničenja brzine na ciljnom prometnom traku, odnosno spriječiti izvođenje takvog poteza na neželjenom mjestu, odaberemo funkciju "izbjegavanje područja ograničene brzine" (Overtake Reduced Speed Areas).

Funkcija "napredno spajanje" (Advanced Merging) omogućuje manje nerealnih čekanja za potrebe mijenjanja prometnog traka, odnosno vozila se za mijenjanje prometnih trakova "odlučuju" prije. Time se propusna moć (kapacitet) ceste povećava i približava realnom stanju. "Kooperativno mijenjanje prometnog traka" (Cooperative Lane Change) pokazuje primjer pražnjenja prometnog traka na autocesti kad se vozila uključuju iz traka za ubrzavanje. 
Ukoliko odaberemo tu mogućnost potrebno je još odrediti "maksimalnu razliku brzine" (Max. Speed Difference) između vozila i "maksimalno vrijeme kolizije" (Max. Collision Time).

\subsubsection{Ostali parametri}

Brzina: Željena brzina, prosječna brzina i konkretna brzina važne su varijable u simulaciji. Terenska (realna) mjerenja brzine mogu se zadati u model preko raspodjele (distribucije) brzine (slika 5.4). Za simulacijske modele (koji su namijenjeni testiranju prometne sigurnosti) vrlo su važni preciznost mjerenja i preciznost unosa raspodjele brzine. Povećavanje prosječne brzine vozila povećava stupanj ozbiljnosti prometnih nesreća i njihovih posljedica.

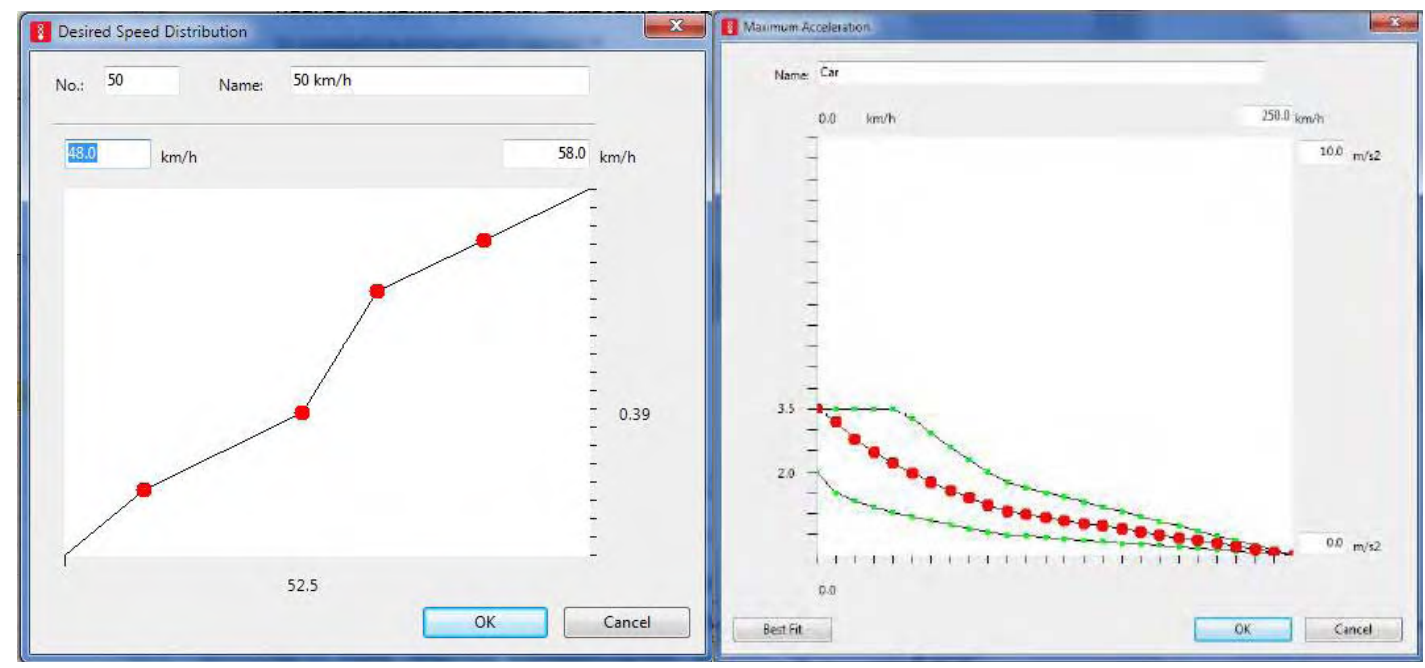

Slika 5.4. Prikaz raspodjele brzine (a) i maksimalnog ubrzanja (b) za osobna vozila [Š. 1$]$

Vissim nema mogućnost zadavanja geometrije ceste (horizontalne i vertikalne), već se sve definira preko brzine.

Karakteristike vozila: Postoji mnoštvo karakteristika vozila koje utječu na prometnu sigurnost i prometne nesreće. Najvažniji parametri su "maksimalno ubrzanje" i "maksimalno usporenje". Mikrosimulacijski program VISSIM ne koristi samo jednu vrijednost za spomenute varijable, već rabi funkcijsku ovisnost ubrzanja i usporenja za svaki tip vozila posebno. Zadane vrijednosti u VISSIM-u plod su dugogodišnjih istraživanja, standardizacije (kalibracija) i validacije simulacijskih modela. Usprkos svemu, korisnik ima mogućnost samostalnog prilagođavanja željenih parametara. Stohastičku "prirodu" ubrzanja i usporenja prikazuje slika 5.4, gdje pojedinu funkciju čine tri krivulje (minimalna, maksimalna i prosječna vrijednost).

Pretjecanje u suprotnom traku: Pretjecanje je uvedeno tek u pretposljednjem izdanju Vissima (Vissim 8). Glavni parametri za pretjecanje su preglednost (Look Ahead Distance), faktor povećanja brzine pri pretjecanju (Overtaking Speed Factor) i brzina suprotnog toka 
(Assumed Speed of Oncomming Traffic). Ove parametre potrebno je definirati za svaki link (zonu pretjecanja) zasebno (slika 5.5).

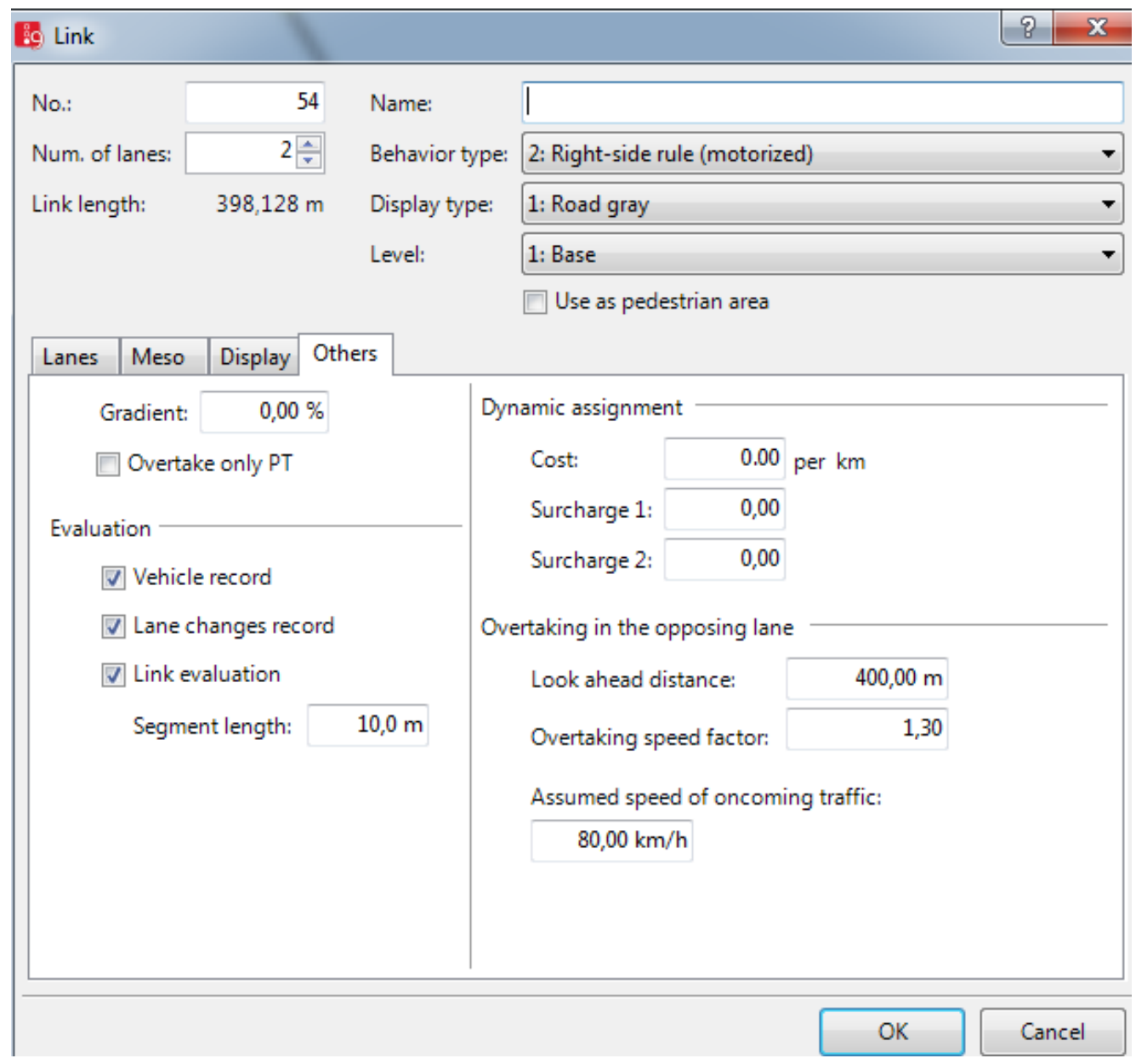

Slika 5.5. Parametri pretjecanja u suprotnom prometnom traku [P.6]

\subsection{Kalibracija modela}

U ovom poglavlju prikazana je kalibracija Vissima 9. Kao što je već rečeno, Vissim predstavlja možda i najsuvremeniji simulacijski alat zasnovan na opsežnim istraživanjima. S obzirom na to, kao i na cilj predmetnog istraživanja, naglasak je bio na kalibraciji najosjetljivijih parametara, a kao takvim su se pokazali željeno vrijeme slijeda i distribucija željenih brzina. Kalibracija pojedinih parametara Vissima provedena je za jednaka prometna opterećenja suprotnih tokova (distrubucija 50/50 \% za opterećenja po smjeru od 200 do $700 \mathrm{voz} / \mathrm{h}$ ). Nakon toga je provedena validacija modela za drugačije distribucije prometnih opterećenja po smjerovima. 


\subsubsection{Model slijeda vozila}

U modelu slijeda vozila najosjetljiviji parametar za PTSF je parametar CC1 koji predstavlja željeno vrijeme slijeda u sekundama. U verziji Vissim 9 ponuđene vrijednosti su 0.5 kao najmanja i 0.9 kao njoj najbliža vrijednost.

Na grafikonu 5.1 prikazani su rezultati vremena slijeda na četiri karakteristične lokacije snimanja ( 2 u pravcu i 2 u krivini), dobiveni na temelju vremena prolaska vozila.

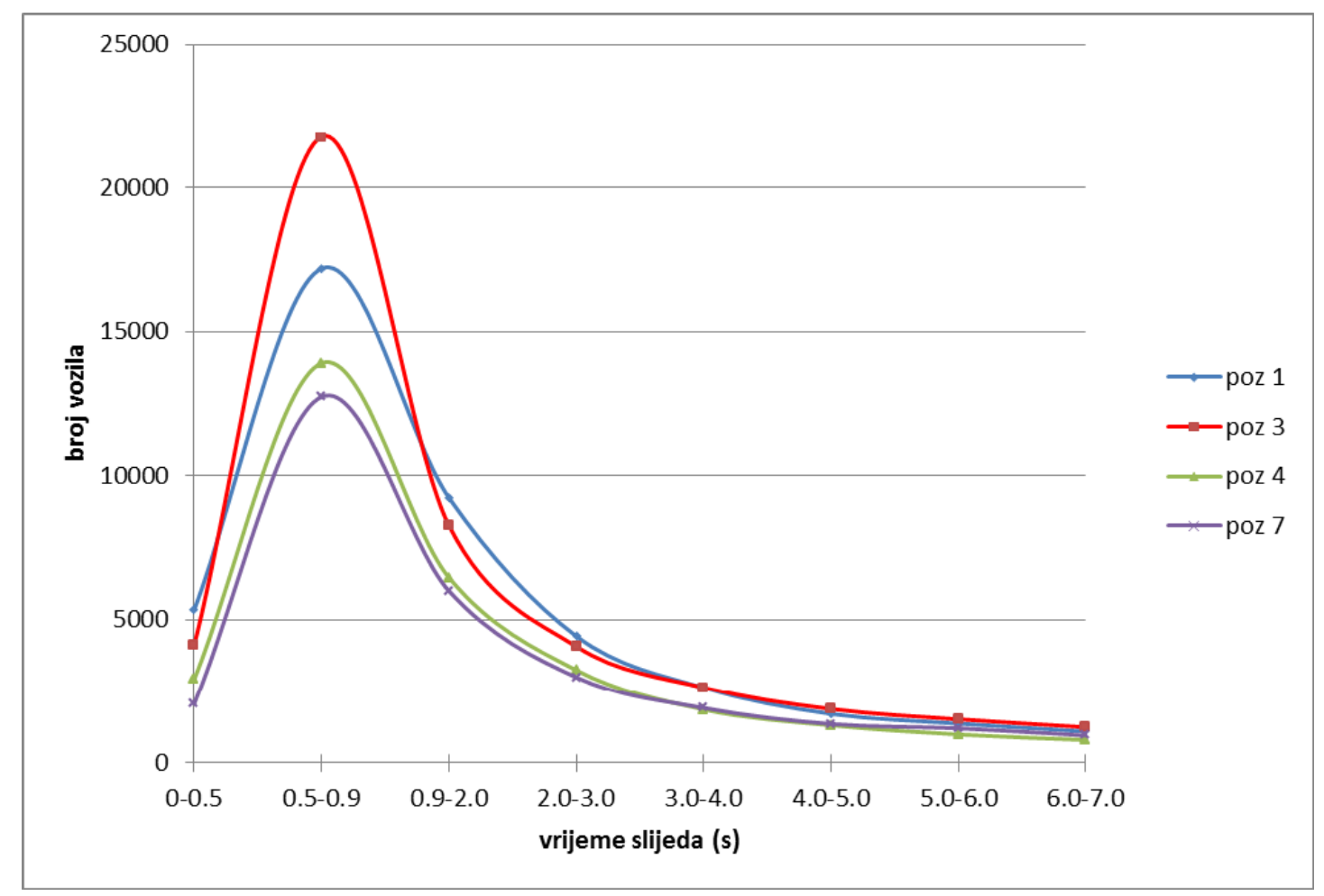

Grafikon 5.1. Vremena slijeda dobivena na 4 brojačka mjesta

Vremena slijeda dobivena na terenu pokazala su kako je njihov najveći broj u rasponu između 0.5 i 0.9 sekundi (grafikon 5.1). Rezultati pokazuju jednake zakonitosti na svim mjerenim presjecima iako se radi o različitim lokalnim uvjetima (geomtriji ceste te time i brzini).

S obzirom da Vissim 9 ne omogućuje odabir neke druge vrijednosti željenog vremena slijeda CC1 (jedino 0.5 i 0.9 sekundi), usvojena je vrijednost 0.5 sekundi jer se dobiju točniji rezultati PTSF-a uspoređujući rezultate modela s onim izmjerenim na terenu.

\subsubsection{Model promjene prometnog traka}

Kod modela promjene prometnog traka zadržane su početne zadane vrijednosti. 


\subsubsection{Ostali parametri}

Distribucija brzina: $\mathrm{Na}$ predmetnoj dionici analizirane su brzine na 4 karakteristična presjeka ( 2 u pravcu i 2 u krivini). Željene brzine $\mathrm{V}_{\mathrm{DES}}$ (desired speed) dobivene su za vremena slijeda veća od 10 sekundi. Istraživanja pokazuju kako interakcija između vozila (car following model) postoji do 7 - 8 sekundi [A.6, A.7, A.8, S2, W.3, W.4] i time su rezultati na strani sigurnosti.

U tablici 5.1 prikazane su prosječne vrijednosti željenih brzina dobivene na terenu za različite tipove vozila (osobna tip 2) u četiri različita karakteristična presjeka. U daljnjoj analizi srednja i teška vozila tretiraju se zajedno kao teška vozila (HV).

Tablica 5.1. Prosječne željene brzine za pojedine tipove vozila

\begin{tabular}{|c|c|c|c|c|c|c|c|c|c|}
\hline \multirow{2}{*}{\begin{tabular}{c}
\multicolumn{1}{c}{ tip } \\
vozila \\
(ARX) \\
\end{tabular}} & \multicolumn{2}{|c|}{ Presjek 1} & \multicolumn{2}{|c|}{ Presjek 3} & \multicolumn{2}{|c|}{ Presjek 4} & \multicolumn{2}{|c|}{ Presjek 7} & \multirow{2}{*}{$\begin{array}{c}\text { Srednja } \\
\text { vrijednost } \\
\text { V }_{\text {des,sred }} \\
\end{array}$} \\
\hline & br. & $V_{\text {des }}$ & br. & $V_{\text {des }}$ & br. & $V_{\text {des }}$ & br. & $V_{\text {des }}$ & \\
\hline 1 & 129 & 99.8 & 112 & 97.8 & 113 & 85.8 & 52 & 87.9 & 92.8 \\
\hline 2 & 17381 & 85.9 & 18141 & 86.1 & 13816 & 86.8 & 15374 & 81.9 & 85.2 \\
\hline 3 & 75 & 79.4 & 69 & 78.9 & 62 & 80.5 & 82 & 74.1 & 78.2 \\
\hline 4 & 2311 & 79.8 & 2415 & 78.8 & 1666 & 80.2 & 2462 & 75.6 & 78.6 \\
\hline 5 & 204 & 79.2 & 227 & 77.4 & 172 & 79.3 & 253 & 73.9 & 77.5 \\
\hline 6 & 35 & 80.3 & 33 & 78.6 & 36 & 81.2 & 46 & 69.0 & 77.3 \\
\hline 7 & 27 & 77.5 & 23 & 74.9 & 14 & 80.7 & 27 & 70.5 & 75.9 \\
\hline 8 & 269 & 76.9 & 253 & 75.4 & 229 & 77.2 & 300 & 72.3 & 75.5 \\
\hline 9 & 1085 & 74.9 & 1046 & 73.8 & 814 & 75.4 & 1175 & 70.9 & 73.8 \\
\hline 10 & 73 & 74.3 & 118 & 75.5 & 56 & 77.2 & 158 & 72.7 & 74.9 \\
\hline 11 & 6 & 74.9 & 12 & 71.2 & 14 & 71.3 & 9 & 65.9 & 70.8 \\
\hline 12 & 44 & 72.8 & 42 & 70.2 & 36 & 75.3 & 22 & 71.5 & 72.5 \\
\hline
\end{tabular}

Iz rezultata u tablici može se vidjeti ujednačenost brzina prema standardnoj podjeli na laka (tipovi 1, 2 i 3), srednja (tipovi 4,5 i 6) i teška vozila (tipovi 7-12). Veća odstupanja daju samo vozila koja imaju zanemariv utjecaj s obzirom na njihov broj (tip 1 i tip 11). Distribucija željenih brzina prikazana je kumulativnim dijagramom na grafikonu 5.2.

Kao što je prethodno spominjano računska brzina dionice ima utjecaj na PTSF, stoga je $\mathrm{i}$ ova analiza ograničena na magistralne ceste $\mathrm{i} \mathrm{V}_{\mathrm{r}}=80 \mathrm{~km} / \mathrm{h}$. Za druge kategorije cesta $\mathrm{i}$ druge brzine potrebna je prilagodba modela. Distribucija brzina ima određene zakonitosti. Šire područje distribucije (veća neujednačenost) znači brži rast PTSF-a na dijelovima dionica bez pretjecanja, ali i veći broj pretjecanja na zonama s pretjecanjem što smanjuje PTSF. 


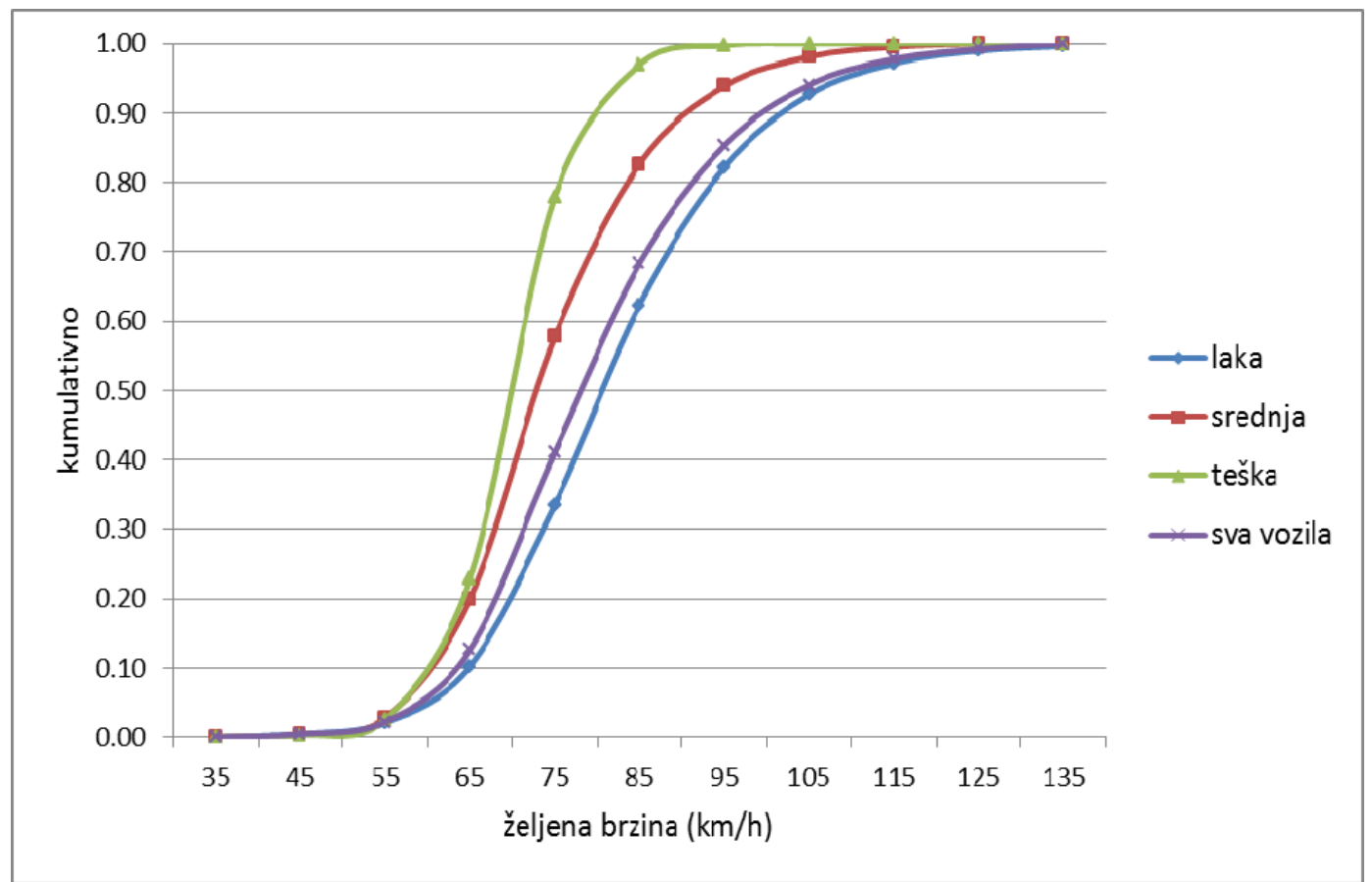

Grafikon 5.2. Kumulativni dijagram željenih brzina pojedinih skupina vozila

U analizi terenskih rezultata uočeno je kako teška vozila vrlo malo utječu na promjenu PTSF-a i neće se uzimati u analize. Razlog malog utjecaja teških vozila može se vidjeti i na prethodnom grafikonu. Iako se distribucija željenih brzina srednjih i teških vozila značajnije razlikuje od lakih, distribucija svih vozila u svom linearnom dijelu (koji se i primjenjuje jer se odbace ekstremi) paralelna je distribuciji lakih vozila. To ustvari predstavlja mali pomak područja distribucije brzina koji vrlo malo utječe na PTSF. U Vissimu je korištena distribucija željenih brzina svih vozila.

Karakteristike vozila: Za karakteristike vozila zadržane su početne vrijednosti.

Pretjecanje u suprotnom traku: Pretjecanje na suprotnom traku definira se preko linka tako što se dodijeli dodatni trak za analizirani smjer (i suprotni za pretjecanje iz suprotnog smjera) koji se preklapa s linkom suprotnog smjera (slika 5.6).

Kao što je ranije spomenuto, parametri duljine preglednosti, faktor povećanja brzine $\mathrm{i}$ brzina suprotnog toka definiraju se zasebno za svaki smjer pojedine zone pretjecanja. Ovi parametri su prilagođeni svakoj pojedinoj zoni pretjecanja. 


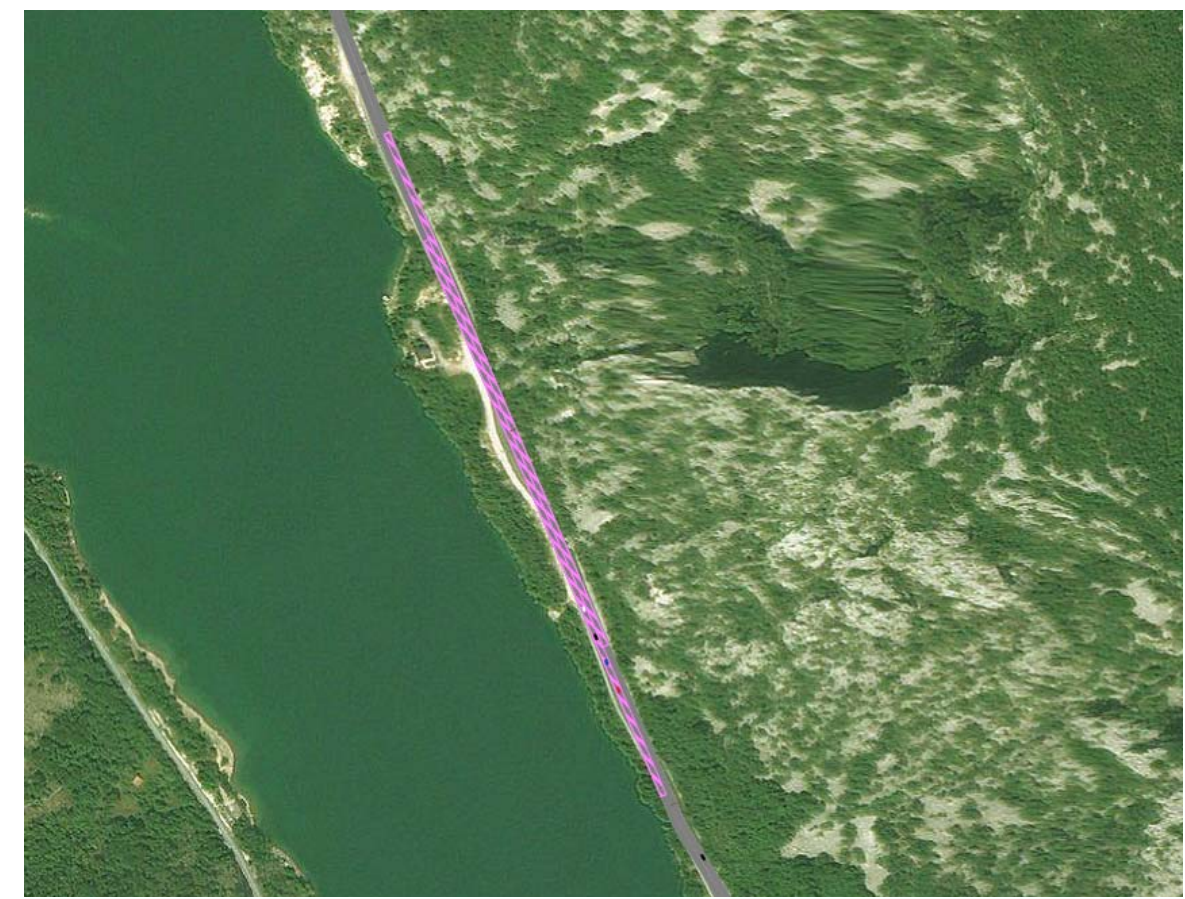

Slika 5.6. Prikaz definiranja zona za pretjecanje u suprotnom traku u Vissimu 9

\subsection{Rezultati kalibracije i validacije modela}

Na osnovu kalibriranih parametara Vissima uslijedila je validacija softwarea. U Vissimu je definirana dionica sa spomenutim parametrima i provedene su simulacije.

Kalibracija ovako duge dionice $(20 \mathrm{~km})$ dosta je složen postupak iz razloga što na terenu, unatoč relativno velikoj homogenosti dionice, uvijek postoje male razlike u operativnim brzinama koje su izazvane različitim lokalnim utjecajima (npr. promjenom geometrije ceste, preglednosti, ometanjima izlaska ili ulaska na dionicu, itd.).

Rezultirajuće vrijednosti simulacije trebale bi biti unutar $5 \%$ odstupanja od onih izmjerenih na terenu što je u validaciji i dobiveno.

Simulacije su provedene za maksimalno $700 \mathrm{voz} / \mathrm{h}$ po smjeru, što predstavlja izuzetno opterećenje za BiH prilike. To su pokazala terenska istraživanja, gdje je vrlo mali postotak satnih opterećenja preko $700 \mathrm{voz} / \mathrm{h}$ po smjeru. Provedeno je po 5 simulacija za svaku kombinaciju prometnog opterećenja u rasponu od 200 do $700 \mathrm{voz} / \mathrm{h}$ za analizirani $\left(\mathrm{V}_{\mathrm{d}}\right)$ i suprotni smjer $\left(\mathrm{V}_{\mathrm{o}}\right)$ te su dobivene prosječne vrijednosti korištene u daljnjim analizama. Razlog primjene 5 simulacija svakog pojedinog slučaja je taj što je 10 simulacija davalo neznatne razlike u odnosu na 5 simulacija.

U Vissimu su zadani mjerni presjeci (Data collection points) svakih $250 \mathrm{~m}$ za bolje praćenje promjena PTSF-a na dionici. Među presjecima su definirani položajno i presjeci koji 
odgovaraju onim mjerenim na terenu (7 glavnih presjeka). Iterativno su provođene simulacije i usporedbe rezultata s onim izmjerenim na terenu.

$\mathrm{Na}$ grafikonu 5.2 prikazan je primjer načina kontrole pojedinih presjeka prilikom validacije. Krivulje predstavljaju promjenu PTSF-a na dionici (svakih $250 \mathrm{~m}$ ), dok velike točke predstavljaju PTSF u 7 terenski mjerenih presjeka.

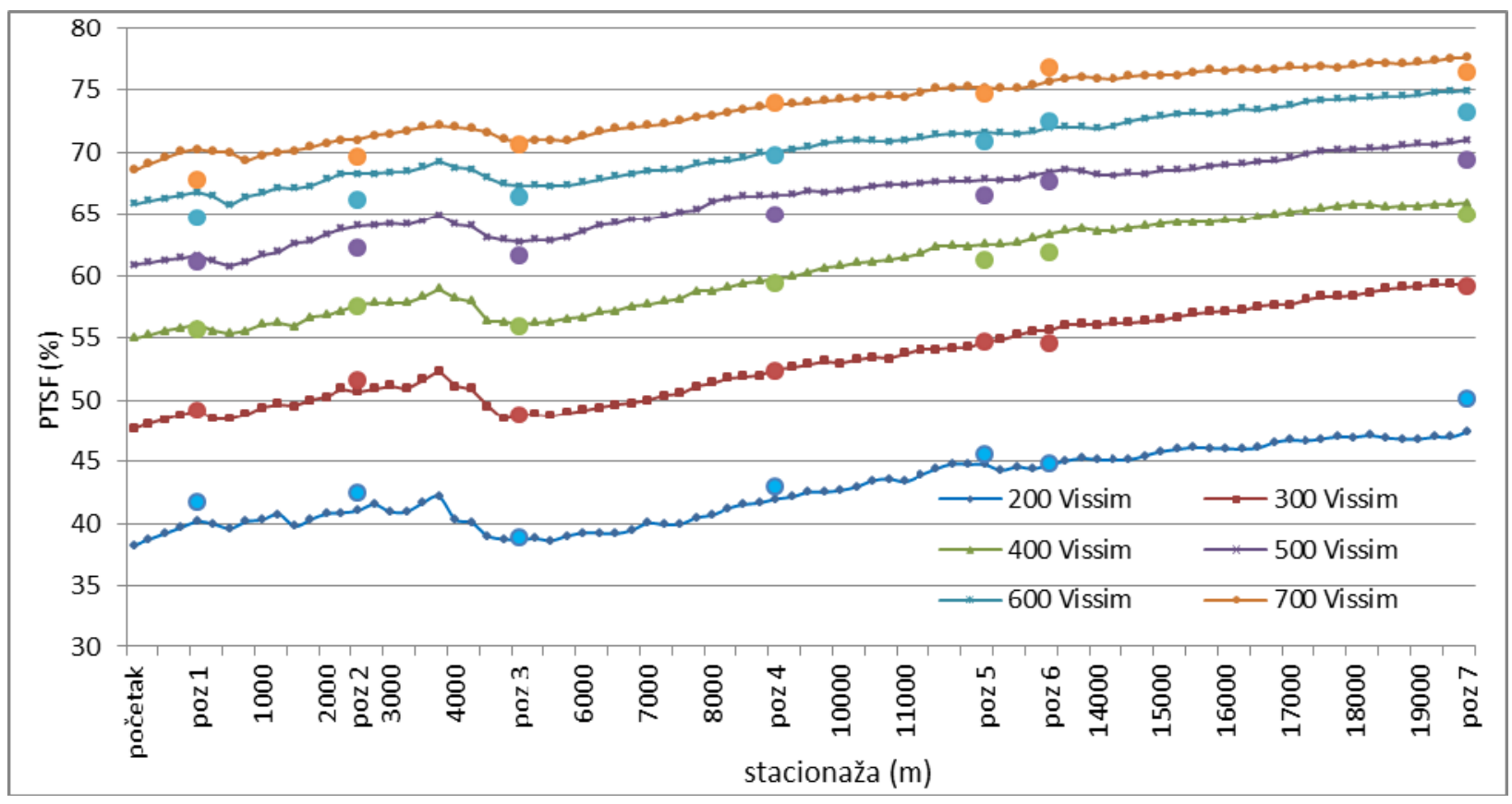

Grafikon 5.2. Poredba PTSF-a s terena (točke) i simulacija za distribuciju 50/50 (smjer Salakovac- Grabovica)

U tablicama 5.2 i 5.3 prikazani su rezultati dobiveni na terenu (prema izrazu 4.12) i simulacijama u Vissimu za oba smjera, Salakovac - Grabovica i Grabovica - Salakovac. Ovi rezultati predstavljaju PTSF cijele dionice.

Tablica 5.2. Poredba PTSF-a s terena i simulacija u Vissimu za smjer Salakovac - Grabovica

\begin{tabular}{|c|c|c|c|c|c|c|c|c|c|c|c|c|}
\hline $\mathbf{V}_{\mathbf{0}}$ & \multicolumn{2}{|c|}{$\mathbf{2 0 0}$} & \multicolumn{2}{c|}{$\mathbf{3 0 0}$} & \multicolumn{2}{c|}{$\mathbf{4 0 0}$} & \multicolumn{2}{c|}{$\mathbf{5 0 0}$} & \multicolumn{2}{c|}{$\mathbf{6 0 0}$} & \multicolumn{2}{c|}{$\mathbf{7 0 0}$} \\
\hline $\mathbf{V}_{\mathbf{d}}$ & teren & Viss. & teren & Viss. & teren & Viss. & teren & Viss. & teren & Viss. & teren & Viss. \\
\hline $\mathbf{2 0 0}$ & 43.42 & 42.89 & 44.03 & 44.03 & 44.64 & 43.73 & 45.26 & 44.25 & 45.87 & 44.90 & 46.49 & 45.42 \\
\hline $\mathbf{3 0 0}$ & 51.65 & 53.38 & 52.27 & 53.38 & 52.88 & 53.71 & 53.50 & 54.04 & 54.11 & 54.59 & 54.73 & 55.34 \\
\hline $\mathbf{4 0 0}$ & 57.50 & 59.85 & 58.11 & 60.35 & 58.73 & 60.70 & 59.34 & 60.94 & 59.96 & 61.36 & 60.57 & 61.64 \\
\hline $\mathbf{5 0 0}$ & 62.03 & 65.44 & 62.65 & 65.91 & 63.26 & 66.22 & 63.87 & 66.40 & 64.49 & 66.68 & 65.10 & 66.92 \\
\hline $\mathbf{6 0 0}$ & 65.73 & 69.82 & 66.35 & 69.92 & 66.96 & 70.05 & 67.58 & 70.12 & 68.19 & 70.51 & 68.81 & 70.87 \\
\hline $\mathbf{7 0 0}$ & 68.87 & 72.96 & 69.48 & 73.05 & 70.10 & 73.42 & 70.71 & 73.52 & 71.32 & 73.59 & 71.94 & 73.86 \\
\hline
\end{tabular}


Tablica 5.3. Poredba PTSF-a s terena i simulacija u Vissimu za smjer Grabovica - Salakovac

\begin{tabular}{|c|c|c|c|c|c|c|c|c|c|c|c|c|}
\hline $\mathbf{V}_{\mathbf{0}}$ & \multicolumn{2}{|c|}{$\mathbf{2 0 0}$} & \multicolumn{2}{|c|}{$\mathbf{3 0 0}$} & \multicolumn{2}{c|}{$\mathbf{4 0 0}$} & \multicolumn{2}{c|}{500} & \multicolumn{2}{|c|}{600} & \multicolumn{2}{c|}{700} \\
\hline $\mathbf{V}_{\mathbf{d}}$ & teren & Viss. & teren & Viss. & teren & Viss. & teren & Viss. & teren & Viss. & teren & Viss. \\
\hline $\mathbf{2 0 0}$ & 45.36 & 44.48 & 46.01 & 44.97 & 46.67 & 44.94 & 47.33 & 45.23 & 47.99 & 45.65 & 48.64 & 45.57 \\
\hline $\mathbf{3 0 0}$ & 53.17 & 54.43 & 53.82 & 54.83 & 54.48 & 54.96 & 55.14 & 56.38 & 55.80 & 55.47 & 56.45 & 55.42 \\
\hline $\mathbf{4 0 0}$ & 58.71 & 61.49 & 59.37 & 61.59 & 60.02 & 61.97 & 60.68 & 62.18 & 61.34 & 62.29 & 62.00 & 62.02 \\
\hline $\mathbf{5 0 0}$ & 63.01 & 66.10 & 63.67 & 66.34 & 64.32 & 66.65 & 64.98 & 66.68 & 65.64 & 67.00 & 66.30 & 67.07 \\
\hline $\mathbf{6 0 0}$ & 66.52 & 69.64 & 67.18 & 69.83 & 67.84 & 69.98 & 68.49 & 68.21 & 69.15 & 70.14 & 69.81 & 70.37 \\
\hline $\mathbf{7 0 0}$ & 69.49 & 72.36 & 70.15 & 72.73 & 70.81 & 72.79 & 71.46 & 72.83 & 72.12 & 72.92 & 72.78 & 73.26 \\
\hline
\end{tabular}

Razlike izmjerenih i simuliranih PTSF-ova (iz tablica 5.2 i 5.3) prikazane su tablicama 5.4 i 5.5.

Tablica 5.4. Razlika rezultata (\%) s terena i simulacija za smjer Salakovac - Grabovica

\begin{tabular}{|c|c|c|c|c|c|c|}
\hline & \multicolumn{6}{|c|}{ Vo } \\
\hline $\mathbf{V}_{\mathbf{d}}$ & $\mathbf{2 0 0}$ & $\mathbf{3 0 0}$ & $\mathbf{4 0 0}$ & $\mathbf{5 0 0}$ & $\mathbf{6 0 0}$ & $\mathbf{7 0 0}$ \\
\hline $\mathbf{2 0 0}$ & $\mathbf{- 1 . 2 2}$ & 0.00 & -2.04 & -2.23 & -2.11 & -2.30 \\
\hline $\mathbf{3 0 0}$ & 3.35 & $\mathbf{2 . 1 2}$ & 1.57 & 1.01 & 0.89 & 1.11 \\
\hline $\mathbf{4 0 0}$ & 4.09 & 3.85 & $\mathbf{3 . 3 5}$ & 2.70 & 2.33 & 1.77 \\
\hline $\mathbf{5 0 0}$ & 5.50 & 5.20 & 4.68 & $\mathbf{3 . 9 6}$ & 3.40 & 2.80 \\
\hline $\mathbf{6 0 0}$ & 6.22 & 5.38 & 4.61 & 3.76 & $\mathbf{3 . 4 0}$ & 2.99 \\
\hline $\mathbf{7 0 0}$ & 5.94 & 5.14 & 4.74 & 3.97 & 3.18 & $\mathbf{2 . 6 7}$ \\
\hline
\end{tabular}

Tablica 5.5. Razlika rezultata (\%) s terena i simulacija za smjer Grabovica - Salakovac

\begin{tabular}{|c|c|c|c|c|c|c|}
\hline & \multicolumn{6}{|c|}{ Vo } \\
\hline $\mathbf{V}_{\mathbf{d}}$ & $\mathbf{2 0 0}$ & $\mathbf{3 0 0}$ & $\mathbf{4 0 0}$ & $\mathbf{5 0 0}$ & $\mathbf{6 0 0}$ & $\mathbf{7 0 0}$ \\
\hline $\mathbf{2 0 0}$ & $\mathbf{- 1 . 9 4}$ & -2.26 & -3.71 & -4.44 & -4.88 & -6.31 \\
\hline $\mathbf{3 0 0}$ & 2.37 & $\mathbf{1 . 8 8}$ & 0.88 & 2.25 & -0.59 & -1.82 \\
\hline $\mathbf{4 0 0}$ & 4.74 & 3.74 & $\mathbf{3 . 2 5}$ & 2.47 & 1.55 & 0.03 \\
\hline $\mathbf{5 0 0}$ & 4.90 & 4.19 & 3.62 & $\mathbf{2 . 6 2}$ & 2.07 & 1.16 \\
\hline $\mathbf{6 0 0}$ & 4.69 & 3.94 & 3.15 & -0.41 & $\mathbf{1 . 4 3}$ & 0.80 \\
\hline $\mathbf{7 0 0}$ & 4.13 & 3.68 & 2.80 & 1.92 & 1.11 & $\mathbf{0 . 6 6}$ \\
\hline
\end{tabular}

Iz tablica se može vidjeti kako su najveće razlike za mala opterećenja (200 i $300 \mathrm{voz} / \mathrm{h}$ ) iz logičnog razloga što je za mala opterećenja veća promjenjivost PTSF-a.

Iz rezultata validacije se vidi da je kalibrirani model postigao zadovoljavajuće rezultate (razlike mjerenog i procijenjenog PTSF-a manje od $5 \%$ ) i kao takav se može primijeniti za simulacije različitih prometnih situacija. 


\section{MODELIRANJE POSTOTKA VREMENA PROVEDENOG U KOLONI}

\subsection{Uvod}

Nakon provedene kalibracije i validacije Vissima 9, sljedeći korak je provođenje simulacija različitih kombinacija prometnog opterećenja i geometrije ceste (u pogledu razmještaja i duljine zona pretjecanja). Pod kombinacijama opterećenja podrazumijeva se kombinacija opterećenja za analizirani i suprotni smjer u rasponu od 200 - $700 \mathrm{voz} / \mathrm{h}$ po smjeru. Kao što je ranije spomenuto manja opterećenja od 200 imaju veliko rasipanje PTSF-a (a nisu ni toliko bitna jer je RU A ili B), dok su veća od 700 voz/h po smjeru rijedak slučaj za BiH prilike. Kombinacije geometrije ceste podrazumijevaju različite duljine i položaje zona pretjecanja.

U poglavlju 4 rečeno je da BPTSF (0 \% zona bez pretjecanja NPZ) nije prikladan za BiH prilike gdje je udio zona bez pretjecanja u rasponu 70 - 100 \%. Prikladniji "bazni” PTSF bio bi slučaj s 100 \% NPZ. Taj slučaj je lakše kalibrirati jer na terenu postoji veliki broj duljih dionica bez ili s malim pretjecanjem. Stoga je definirana prosječna vrijednost PTSF-a za dionicu bez mogućnosti pretjecanja (100\% NPZ) i nazvana je prosječni $P T S F \overline{100 \% N P Z}$ te se može dobiti na dva načina.

Prvi način dobivanja je preko poznatog (izmjerenog) početnog PTSF $_{\text {poč }}$ (PTSF u stacionaži 0+000) za određeno prometno opterećenje uvećanog za rast PTSF-a po duljini dionice, dok drugi način daje "prosječne" vrijednosti $P T S F \overline{100 \% N P Z}$ kada nema mjerenja PTSF-a na terenu (opisano u poglavlju 6.2).

Uočeno je da PTSF raste na dijelu dionica bez pretjecanja, kao i na dionicama s kratkim zonama pretjecanja. Taj porast je definiran kao nakupljanje.

Isto tako, PTSF raste do neke maksimalne vrijednosti kada se formirane kolone ustale i definiran je kao maksimalni PTSF max $_{\text {. }}$

Nakon što je definiran $P T S F_{100 \% N P Z}$ kao "bazni”, potrebno je odrediti veličinu korekcijskih faktora koji će ga umanjivati i koji predstavljaju utjecaje zona pretjecanja. Veća duljina zone pretjecanja znači veći faktor utjecaja i manji PTSF analizirane dionice.

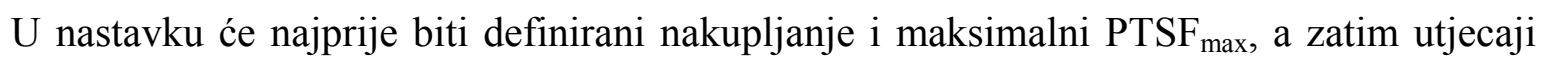
zona za pretjecanje različitih duljina. $\mathrm{Na}$ osnovu toga će biti definiran novi model za proračun PTSF-a.

Model PTSF-a je validiran na drugoj dionici i rezultati su prikazani na kraju poglavlja. 


\subsection{Definiranje nakupljanja i maksimalnih vrijednosti PTSF-a}

Nakon kalibracije i validacije Vissima, gdje se dobila "realna simulacija" prometa postojeće dionice, sljedeći korak bile su simulacije dionice bez pretjecanja. Dionica bez pretjecanja modelirana je na način da su zabranjena pretjecanja na svim zonama pretjecanja analizirane dionice. Na ovaj način dobije se nakupljanje i prosječni $P T S F \overline{100 \% N P Z}$ koji je prosječna vrijednost PTSF-ova dobivenih na zadanim presjecima (svakih $250 \mathrm{~m}$ ) u simulaciji.

$\mathrm{Na}$ sljedećim grafikonima prikazane su promjene PTSF-a (rezultati odabranih 1655 simulacija) za slučajeve bez pretjecanja i s pretjecanjem kakvo je na analiziranoj dionici (13 zona pretjecanja, $1100 \mathrm{~m}$ i $700 \mathrm{~m}$, te 11 dionica duljine 400 - $450 \mathrm{~m}$ ) za raspodjelu opterećenja 50/50. Zbog opsežnosti grafički su prikazani rezultati samo za smjer Salakovac - Grabovica, dok su tablično prikazana oba smjera.

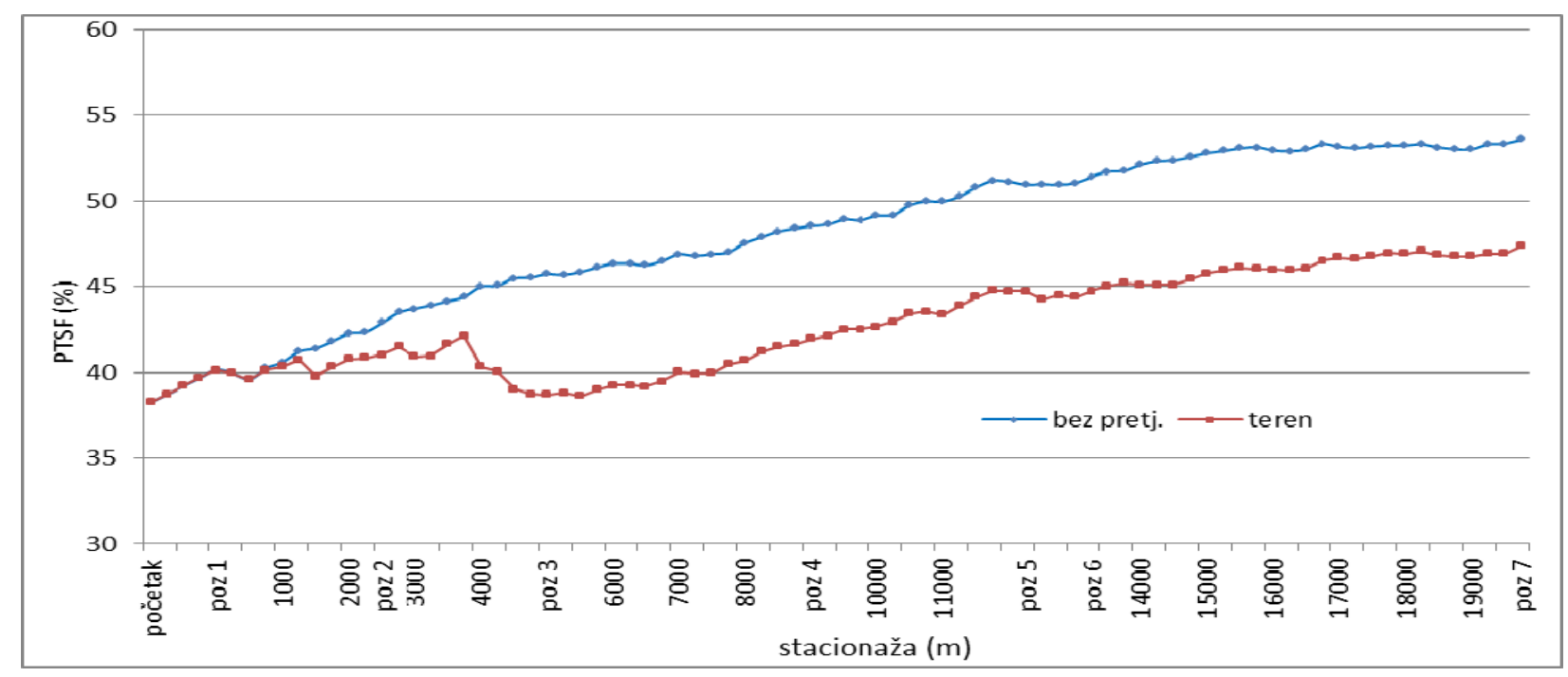

Grafikon 6.1. Promjena PTSF-a za opterećenje 200 voz/h po smjeru

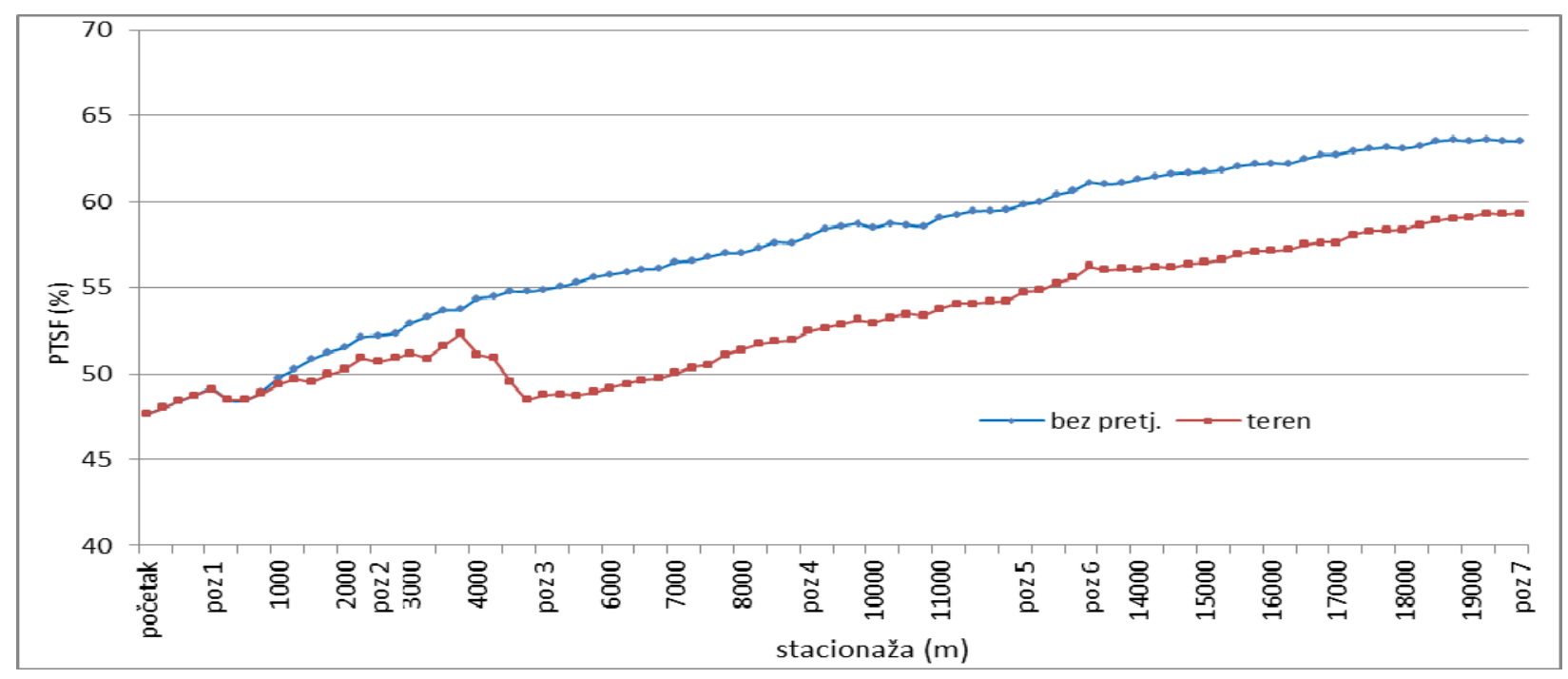

Grafikon 6.2. Promjena PTSF-a za opterećenje 300 voz/h po smjeru 


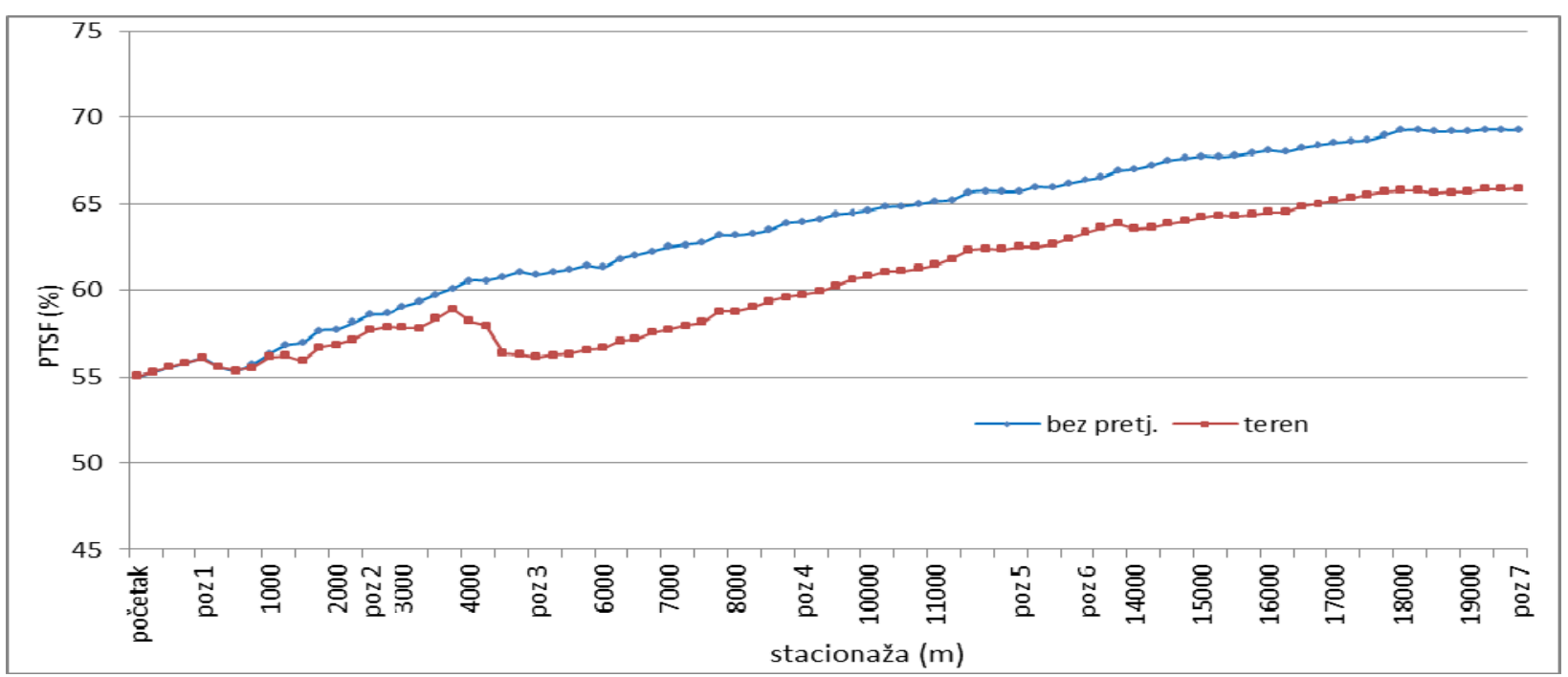

Grafikon 6.3. Promjena PTSF-a za opterećenje 400 voz/h po smjeru

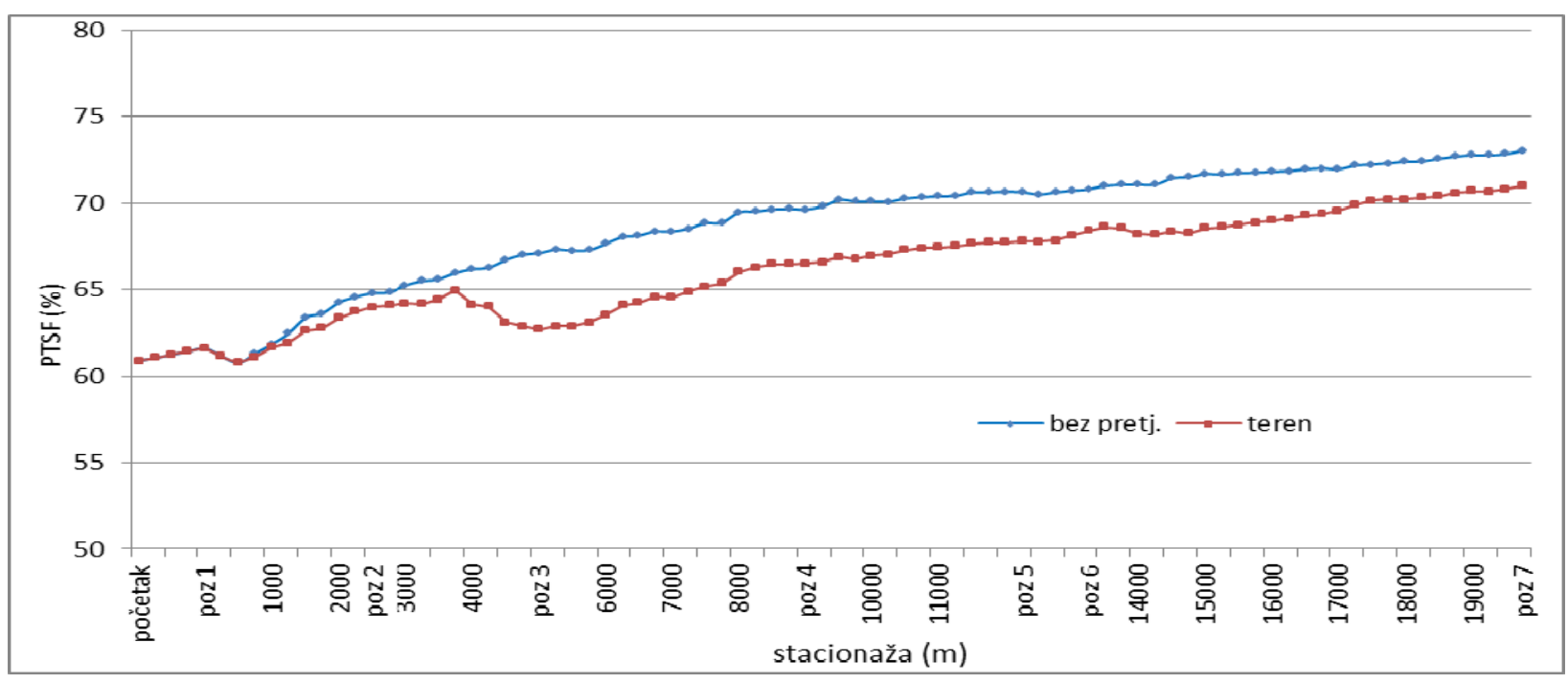

Grafikon 6.4. Promjena PTSF-a za opterećenje 500 voz/h po smjeru

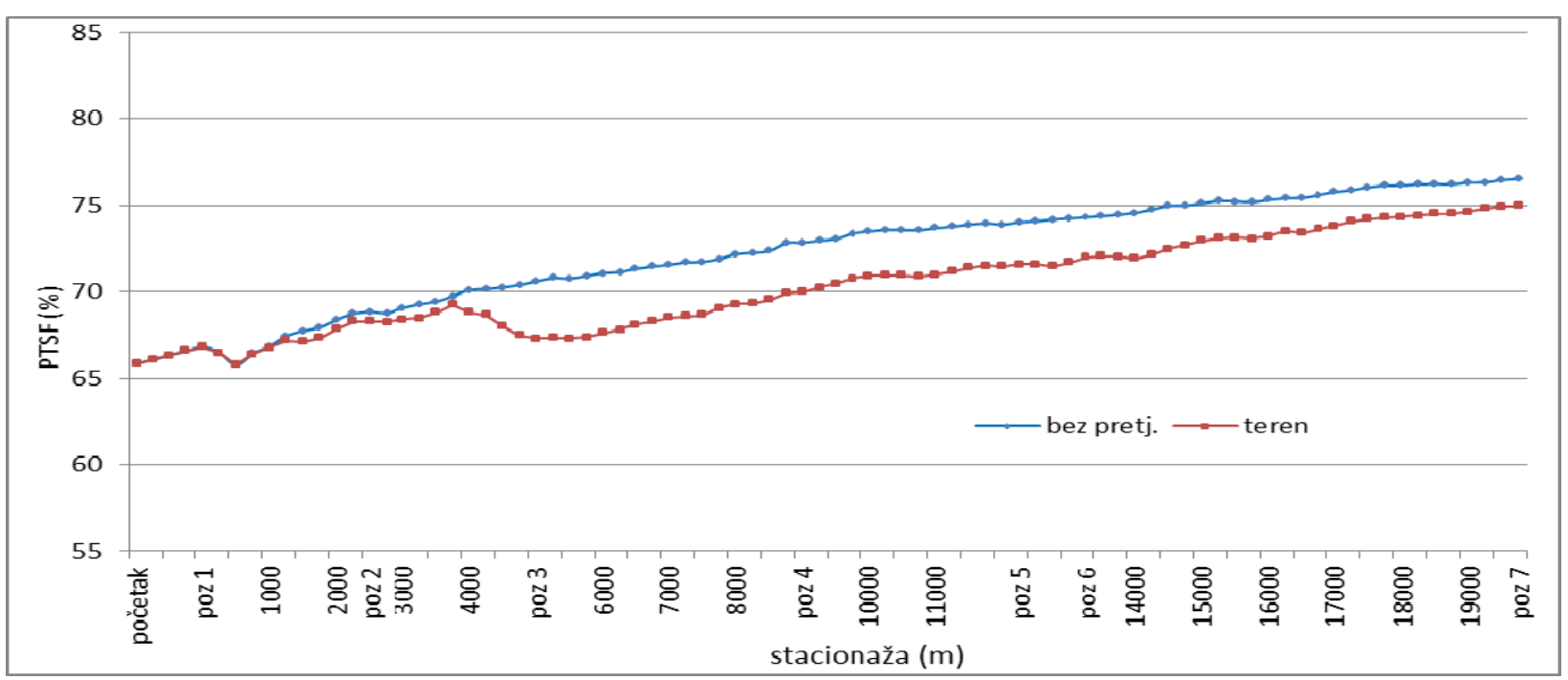

Grafikon 6.5. Promjena PTSF-a za opterećenje 600 voz/h po smjeru 


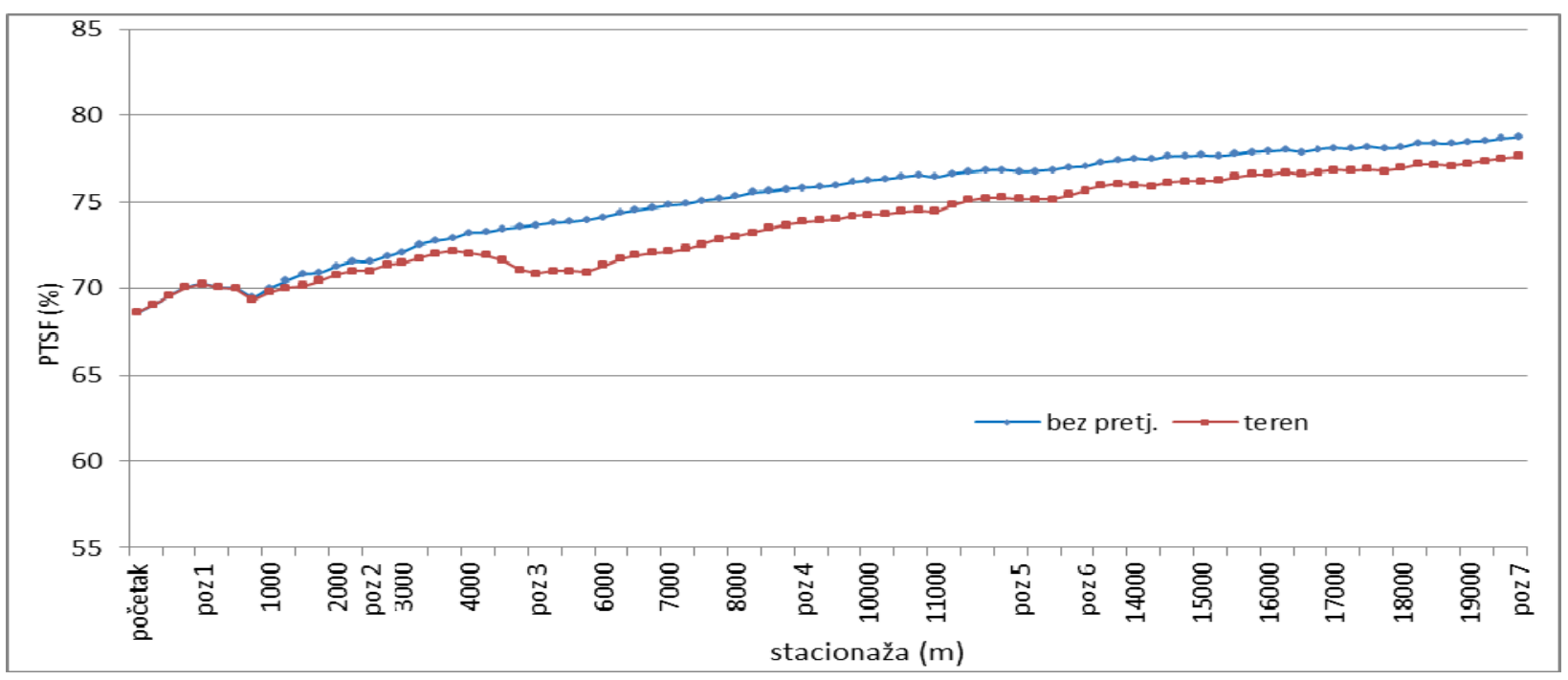

Grafikon 6.6. Promjena PTSF-a za opterećenje 700 voz/h po smjeru

Na prethodnim grafikonima prikazana je promjena PTSF-a na dionici za „postojeće stanje“ i za slučaj kada nema pretjecanja. Razlika vrijednosti dviju krivulja u stvari predstavlja ukupni utjecaj prethodno spomenutih 13 zona pretjecanja na PTSF dionice. Vrijednosti PTSF-a za ova dva slučaja i njihove razlike prikazane su u tablici 6.1. Prikazani su rezultati za oba smjera i

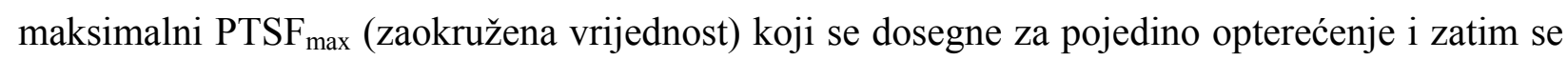
ustali vrijednost (ponavljanje vrijednosti u presjecima u kontinuitetu za sva opterećenja nakon 18 $500 \mathrm{~m}$ ). Vrijednosti $P T S F_{100 \% N P Z}$ se vrlo malo razlikuju po smjerovima (zbog različitog početnog PTSF-a) pa su stoga usvojene zaokružene vrijednosti (prikazane u tablici 6.1).

Tablica 6.1. PTSF simulacija postojeće dionice i dionice bez pretjecanja

\begin{tabular}{|c|c|c|c|c|c|c|}
\hline $\mathbf{V}_{\mathbf{d}}$ & $\begin{array}{c}P T S F_{-100 \% N P Z} \\
\text { bez } \\
\text { pretjecanja } \\
\text { smjer } \\
\text { Mo-Sa }\end{array}$ & $\begin{array}{c}P T S F_{100 \% N P Z} \\
\text { bez } \\
\text { pretjecanja } \\
\text { smjer } \\
\text { Sa-Mo }\end{array}$ & $\begin{array}{c}\text { usvojeni } \\
P T S F_{-100 \% N P Z} \\
\text { bez } \\
\text { pretjecanja }\end{array}$ & $\begin{array}{c}\text { postojeća } \\
\text { dionica } \\
\text { smjer } \\
\text { Mo-Sa }\end{array}$ & $\begin{array}{c}\text { postojeća } \\
\text { dionica } \\
\text { smjer } \\
\text { Sa-Mo }\end{array}$ & $P T S F_{\max }$ \\
\hline $\mathbf{2 0 0}$ & 48.49 & 47.39 & $\mathbf{4 8 . 0 0}$ & 42.89 & 44.48 & 54.00 \\
\hline $\mathbf{3 0 0}$ & 57.89 & 57.14 & $\mathbf{5 8 . 0 0}$ & 53.38 & 54.83 & 64.00 \\
\hline $\mathbf{4 0 0}$ & 63.89 & 63.76 & $\mathbf{6 4 . 0 0}$ & 60.70 & 61.97 & 69.00 \\
\hline $\mathbf{5 0 0}$ & 68.95 & 68.59 & $\mathbf{6 9 . 0 0}$ & 66.40 & 66.68 & 73.00 \\
\hline $\mathbf{6 0 0}$ & 72.56 & 71.69 & $\mathbf{7 2 . 0 0}$ & 70.51 & 70.14 & 76.00 \\
\hline $\mathbf{7 0 0}$ & 75.40 & 74.48 & $\mathbf{7 5 . 0 0}$ & 73.86 & 73.26 & 79.00 \\
\hline
\end{tabular}

Grafikon 6.7 prikazuje promjenu PTSF-a za slučaj bez pretjecanja, za opterećenja od 200 do $700 \mathrm{voz} / \mathrm{h}$. U ovom slučaju bitan je samo analizirani tok, dok suprotni tok ne utječe na PTSF. 


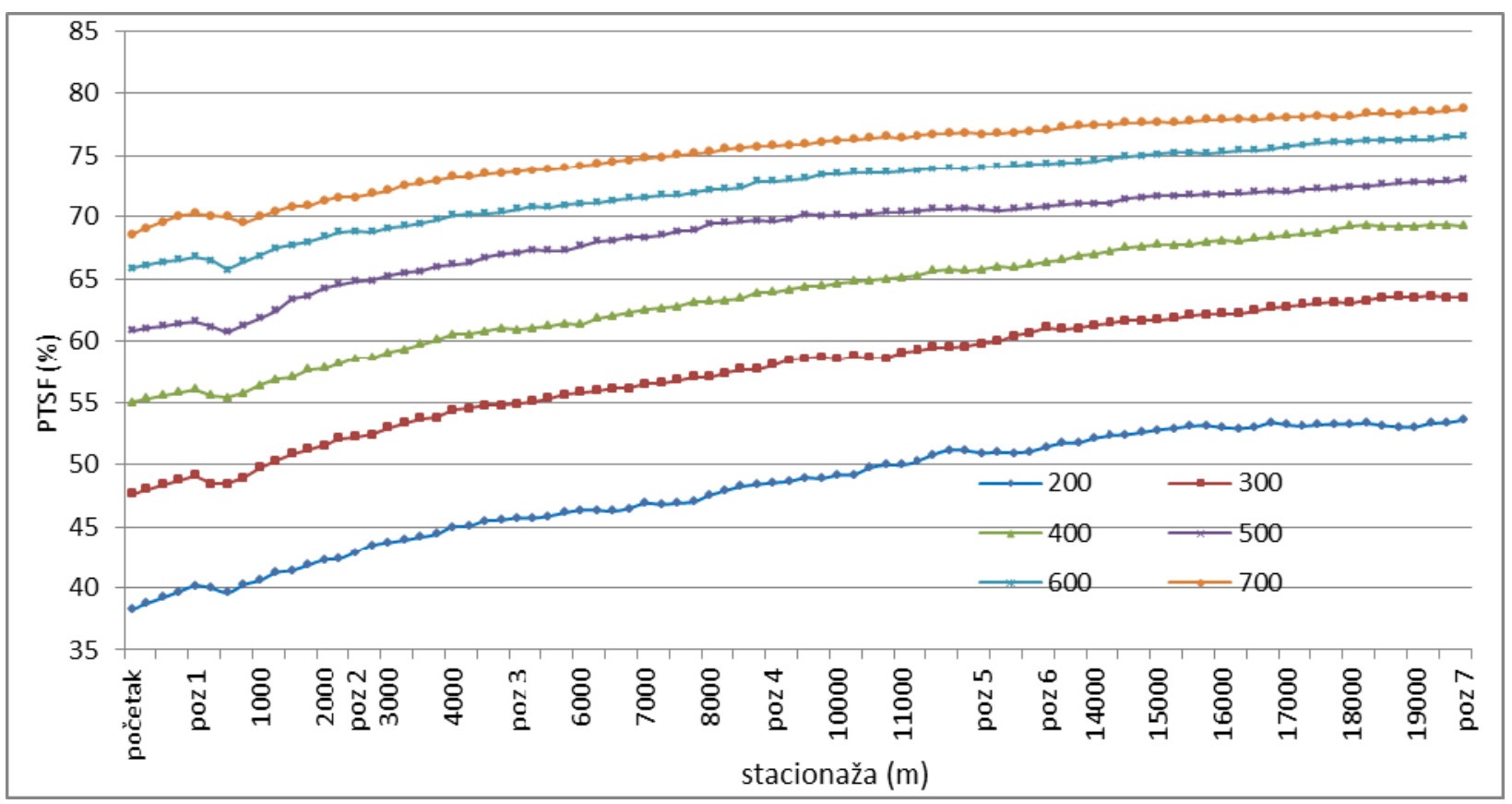

Grafikon 6.7. Promjena PTSF-a za dionicu bez pretjecanja

Kao što se može vidjeti iz prethodnog grafikona, porast PTSF-a (nakupljanje) približno je linearan dok se ne postigne vrijednost PTSF $_{\max }$. Linearni porast PTSF-a (ovisi o prometnom opterećenju) odvija se na duljini gotovo $15 \mathrm{~km}$ (nakon $15 \mathrm{~km}$ je manji porast i ustaljuje se vrijednost na $\mathrm{PTSF}_{\max }$ ) i prikazn je na grafikonu 6.8 .

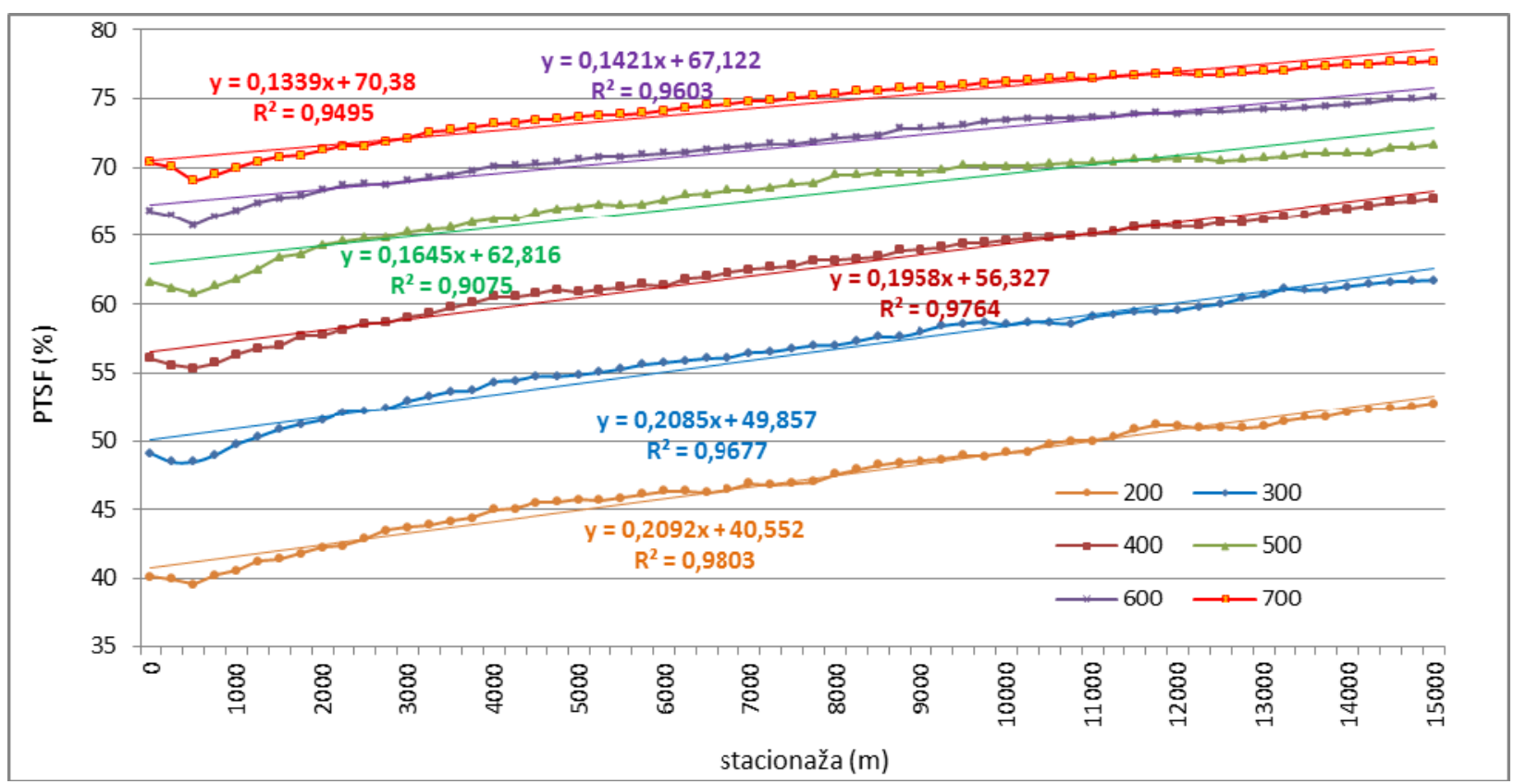

Grafikon 6.8. Linearna promjena PTSF-a za za dionicu bez pretjecanja

Zakonitosti nakupljanja mogu se izraziti kao rast PTSF-a po jedinici duljine, s tim da su jednadžbe pravaca dobivene za zadane presjeke razmaka $250 \mathrm{~m}$ (podjela na apscisi). Vrijednosti nakupljanja po kilometru duljine dane su u tablici 6.2. 


\section{Način određivanja $P T S F_{100 \% N P Z}$ :}

Za poznato nakupljanje maksimalna vrijednost PTSF-a dionice može se odrediti i za bilo koju duljinu dionice, ali je nužno znati (izmjeriti) početnu vrijednost PTSF $_{\text {poč. }} P T S F \overline{100 \% N P Z}$ predstavlja prosječnu vrijednost početne $\left(P T S F_{\text {poč }}\right)$ i krajnje vrijednosti na duljini nakupljanja (L) dionice. Izraz za proračun je kako slijedi:

$$
P T S F_{100 \% N P Z}=\frac{P T S F_{p o c ̌}+\left(P T S F_{p o \check{c}}+k_{n a k} \cdot L_{d}\right)}{2},\left(\leq P T S F_{\max }\right)
$$

Iz prethodnog se dobije izraz:

$$
P T S F_{100 \% N P Z}=P T S F_{p o \check{c}}+k_{n a k} \cdot L_{d} / 2,\left(\leq P T S F_{\max }\right)
$$

Gdje su:

- $\quad P T S F \overline{100 \% N P Z}=$ prosječna vrijednost PTSF-a za NPZ 100\%

- $\quad P T S F_{\text {poč }}=$ vrijednost PTSF-a na početku dionice

- $\quad k_{n a k}=$ nakupljanje PTSF-a po kilometru duljine $(\% / \mathrm{km})$

- $\quad L_{d}=$ duljina dionice $(\mathrm{km})$

- $P T S F_{\max }=$ maksimalna vrijednost koju dosegne PTSF

Kao što je prethodno spomenuto PTSF može rasti samo do maksimalne vrijednosti, stoga dobiveni $P T S F_{100 \% N P Z}$ mora biti manji ili jednak $P T S F_{\max }$. Za poznate početne vrijednosti PTSF $_{\text {poč }}$, te definirane poraste po kilometru duljine, dobivene su po smjerovima vrijednosti $P T S F_{100 \% N P Z}$ za predmetnu dionicu duljine $19.75 \mathrm{~km}$ (tablica 6.2).

Na ovakav način definira se preko PTSF $\overline{100 \% N P Z}$ „,bazni“ PTSF koji predstavlja temelj za proračun PTSF-a dionice.

Tablica 6.2. Nakupljanje PTSF-a po kilometru duljine

\begin{tabular}{|c|c|c|c|c|c|c|c|}
\hline $\mathbf{\mathbf { V } _ { \mathbf { d } }}$ & $\begin{array}{c}\text { porast } \\
\mathbf{P T S F} \\
\mathbf{n a} \\
\mathbf{2 5 0} \mathbf{~ m} \\
\text { duljine }\end{array}$ & $\begin{array}{c}\mathbf{k}_{\text {nak }} \\
\mathbf{\%} / \mathbf{k m}\end{array}$ & $\begin{array}{c}P T S F_{\text {poc }} \\
\text { smjer } \\
\mathbf{M o - S a}\end{array}$ & $\begin{array}{c}P T S F_{\text {poc }} \\
\text { smjer } \\
\text { Sa-Mo }\end{array}$ & $\begin{array}{c}P T S F_{100 \% N P Z} \\
\text { bez } \\
\text { pretjecanja } \\
\text { smjer } \\
\text { Mo-Sa }\end{array}$ & $\begin{array}{c}P T S F_{100 \% N P Z} \\
\text { bez } \\
\text { pretjecanja } \\
\text { smjer } \\
\text { Sa-Mo }\end{array}$ & $\begin{array}{c}\text { usvojeni } \\
P T S F_{100 \% N P Z} \\
\text { bez } \\
\text { pretjecanja }\end{array}$ \\
\hline $\mathbf{2 0 0}$ & 0.2092 & 0.84 & 40.15 & 39.56 & 48.41 & 47.82 & 48.00 \\
\hline $\mathbf{3 0 0}$ & 0.2085 & 0.83 & 49.10 & 48.85 & 57.34 & 57.09 & 58.00 \\
\hline $\mathbf{4 0 0}$ & 0.1958 & 0.78 & 56.05 & 56.71 & 63.78 & 64.44 & 64.00 \\
\hline $\mathbf{5 0 0}$ & 0.1645 & 0.66 & 61.61 & 61.75 & 68.11 & 68.25 & 69.00 \\
\hline $\mathbf{6 0 0}$ & 0.1421 & 0.57 & 66.81 & 66.37 & 72.42 & 71.98 & 72.00 \\
\hline $\mathbf{7 0 0}$ & 0.1339 & 0.54 & 70.37 & 69.80 & 75.66 & 75.09 & 75.00 \\
\hline
\end{tabular}


Rezultati $P T S F_{100 \% N P Z}$ dobiveni na ovaj način gotovo su jednaki rezultatima dobivenim bez korištenja faktora rasta $\mathrm{k}_{\text {nak }}$ (tablica 6.1).

\subsection{Definiranje utjecaja zona pretjecanja na PTSF dionice}

Kako bi se odredio utjecaj pojedinih zona pretjecanja provedene su simulacije dionica za pojedinačne zone pretjecanja. Najprije su simulirane varijante kada bi na analiziranoj dionici postojala samo zona za pretjecanje duljine $1100 \mathrm{~m}$. Nakon toga su na isti način simulirane varijante s pretjecanjem zona duljine $700 \mathrm{~m}$ i $450 \mathrm{~m}$. S obzirom na mali utjecaj duljine zona od 450 m, uključeno je svih 11 zona pretjecanja. Promjene PTSF-a za navedene slučajeve prikazane su grafikonima koji slijede (raspodjela po smjeru 50/50).

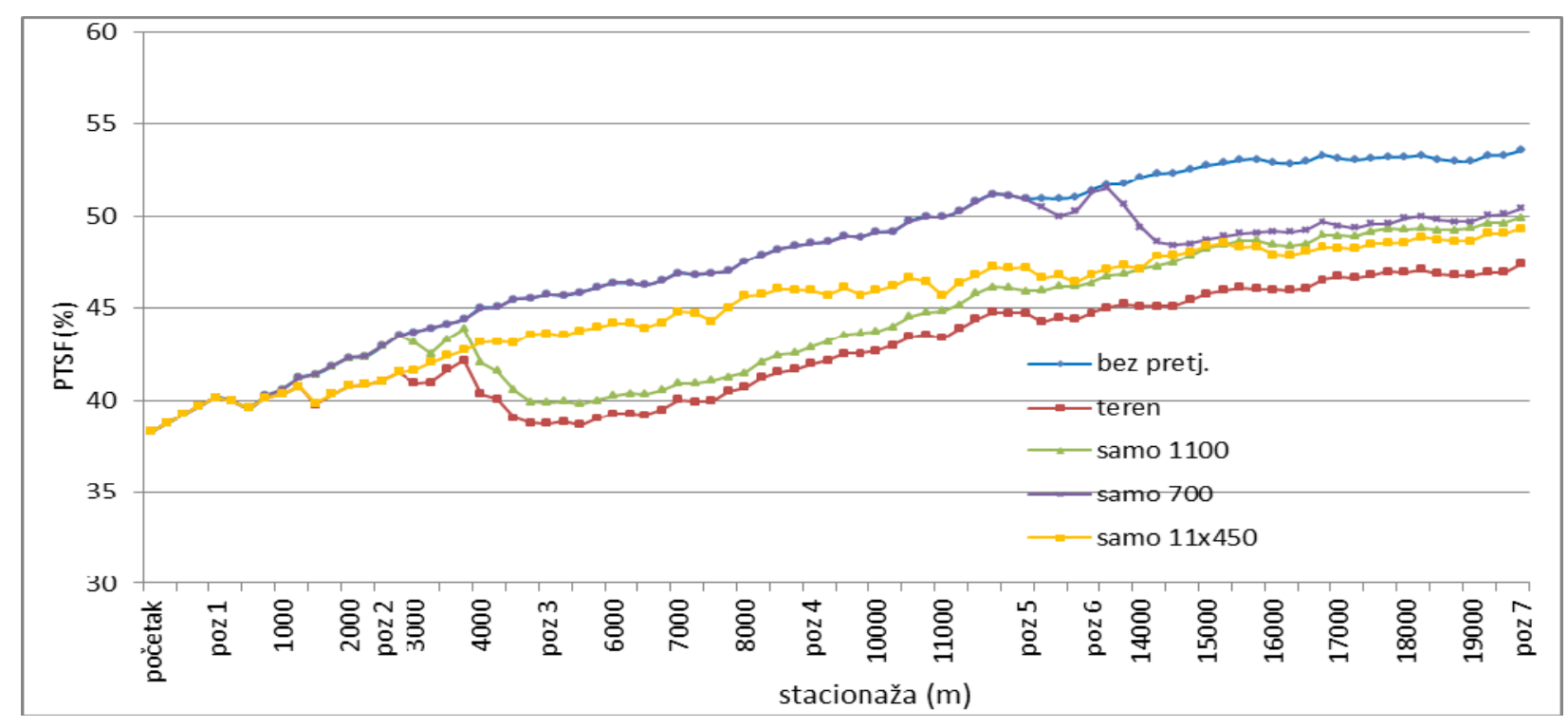

Grafikon 6.9. Promjena PTSF-a za opterećenje po 200 voz/h u oba smjera

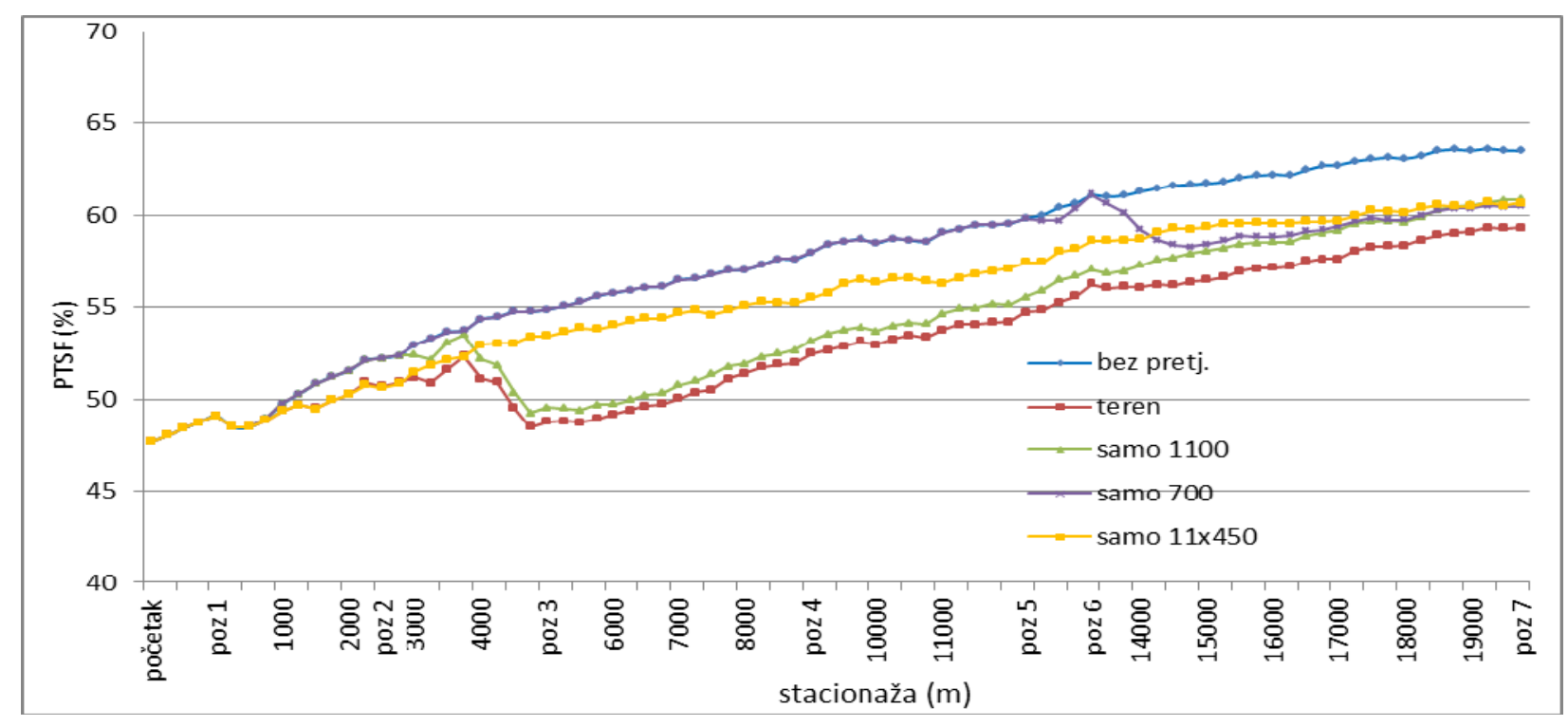

Grafikon 6.10. Promjena PTSF-a za opterećenje po 300 voz/h u oba smjera 


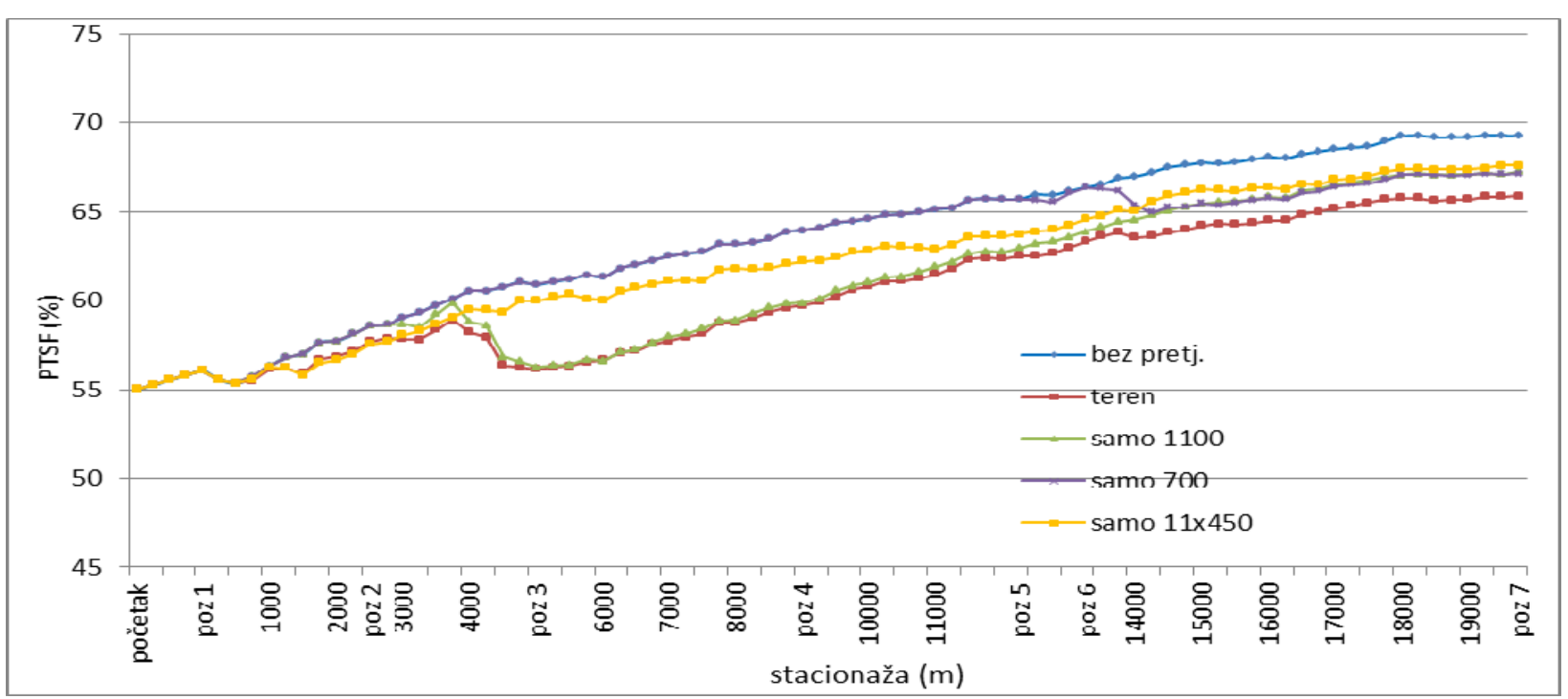

Grafikon 6.11. Promjena PTSF-a za opterećenje po 400 voz/h u oba smjera

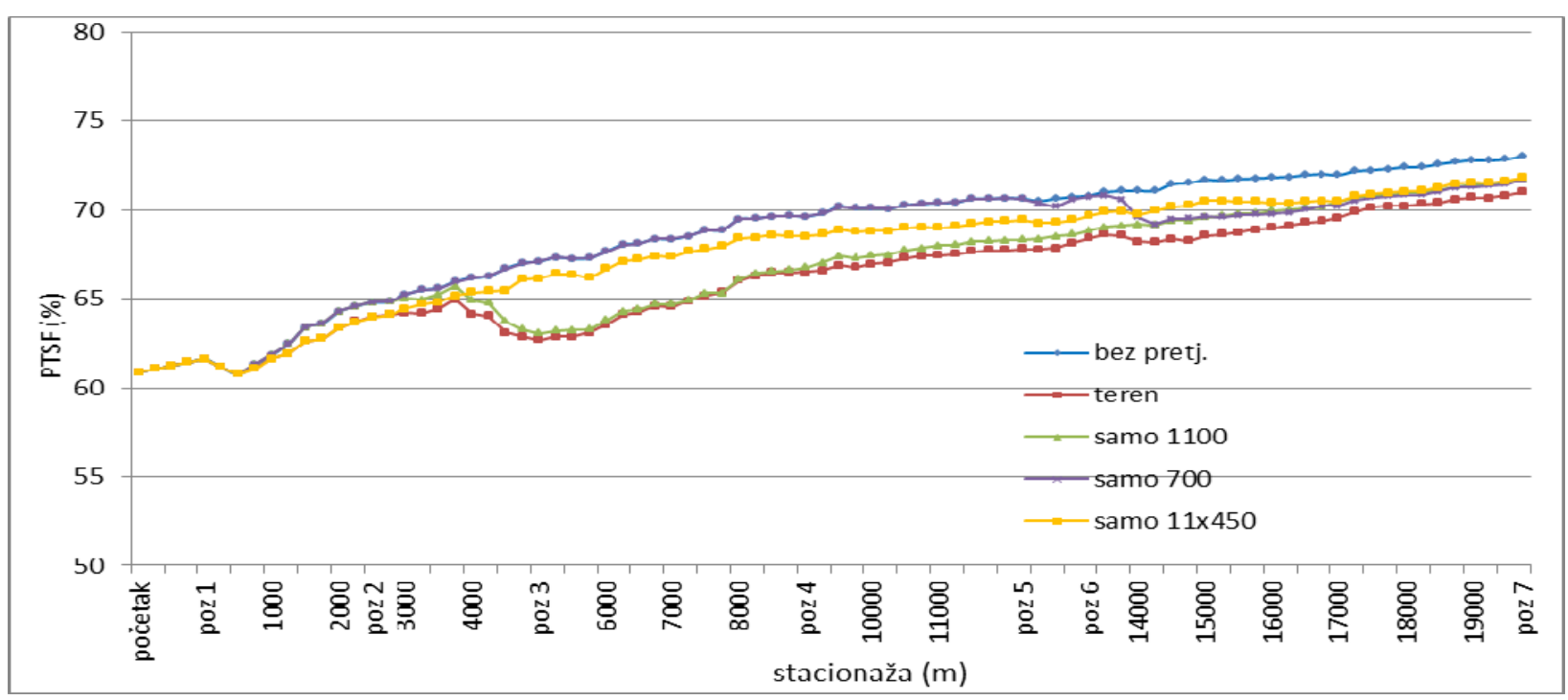

Grafikon 6.12. Promjena PTSF-a za opterećenje po 500 voz/h u oba smjera

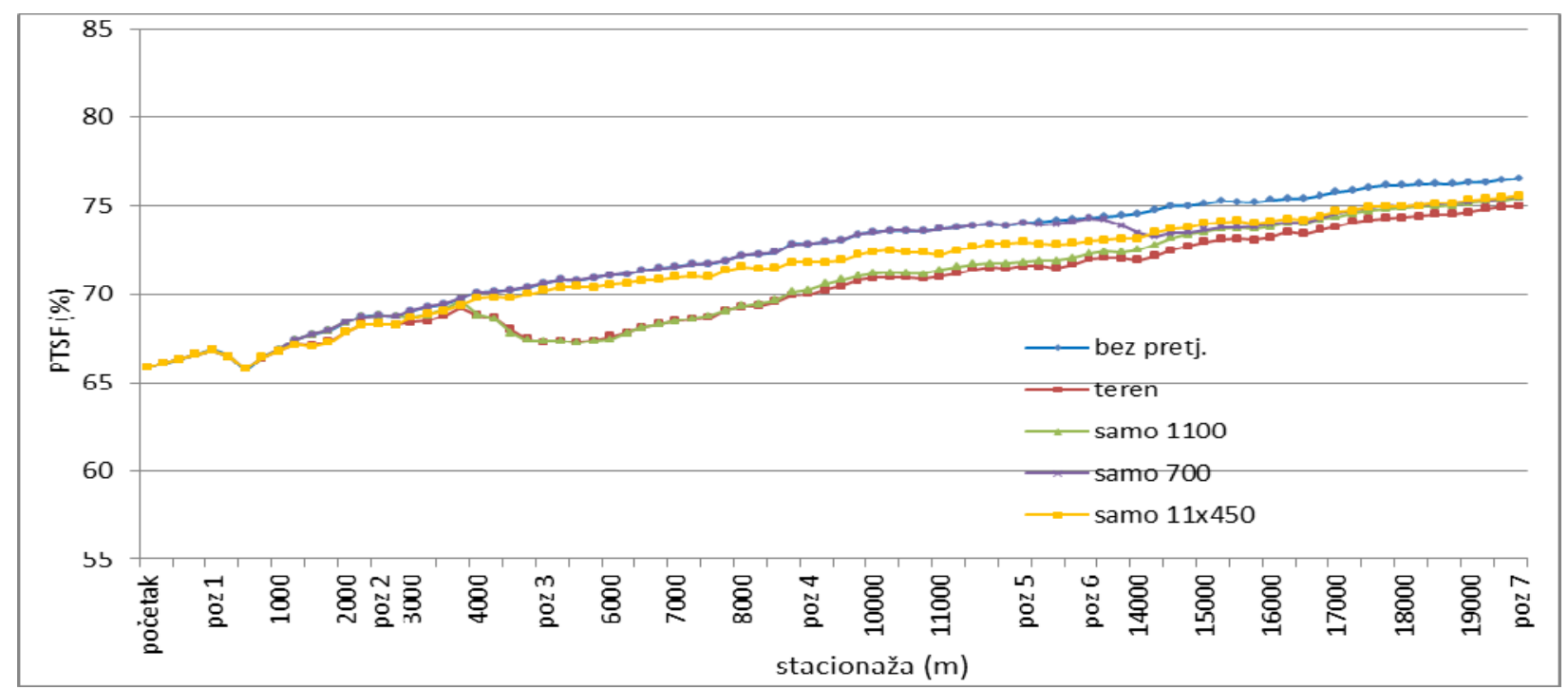

Grafikon 6.13. Promjena PTSF-a za opterećenje po 600 voz/h u oba smjera 


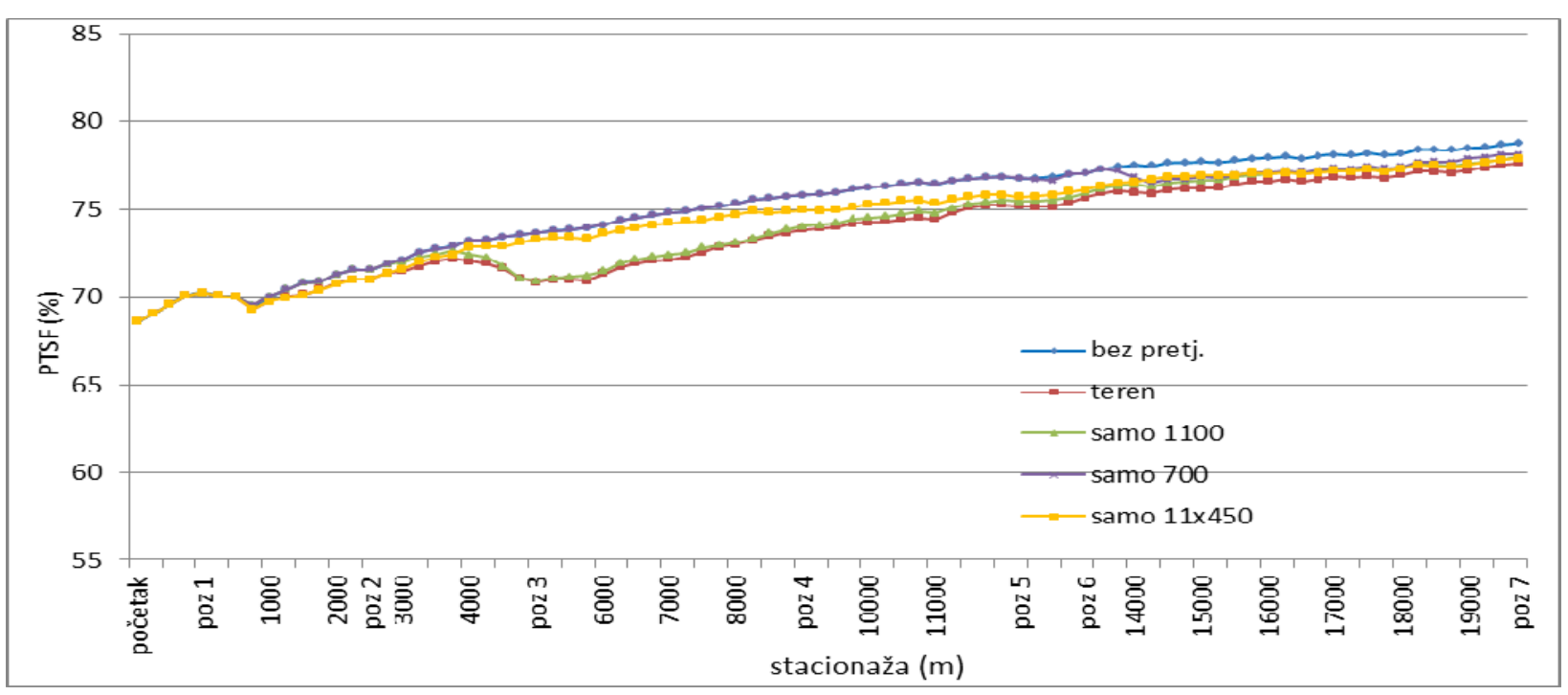

Grafikon 6.14. Promjena PTSF-a za opterećenje po 700 voz/h u oba smjera

$\mathrm{Na}$ temelju razlika PTSF-a simulacije bez pretjecanja $\left(P T S F_{100 \% N P Z}\right)$ i pojedine uključene zone pretjecanja može se dobiti izravan utjecaj pojedine zone. Rezultati provedenih analiza su prikazani u tablicama $6.3-6.10$.

Provedene su simulacije i kombinacija zona pretjecanja, kao npr. uključivanjem zajedno zona duljina $1100 \mathrm{~m}$ i $700 \mathrm{~m}, 1100 \mathrm{~m}$ i zona $450 \mathrm{~m}, 700 \mathrm{~m}$ i $450 \mathrm{~m}$, itd. Zatim su simulirane „nove“ dionice sa po dvije zone duljina 1100 m, kao i 700 m, uz različite položaje na dionici.

Rezultati su pokazali utjecaj položaja zone pretjecanja na PTSF analizirane dionice, kao i određena međusobna superponiranja zona pretjecanja. Utjecaj zone pretjecanja veći je kada je zona na početku analiziranog smjera (za suprotni obrnuto) i kada je to jedina zona pretjecanja na dionici, ali dobivene razlike u vrijednosti PTSF-a nisu velike.

S obzirom da je nemoguće ,pokriti“ sve kombinacije položaja i zajedničkih pojavljivanja različitih duljina zona pretjecanja, zone su analizirane pojedinačno. Njihov utjecaj se definirao kao prosječna vrijednost oba smjera analizirane dionice, što daje najmanja odstupanja od prethodno spomenutih mogućih situacija na terenu (kombinacije položaja i duljina zona).

Tablica 6.3. Prikaz vrijednosti PTSF-a za dionicu Salakovac - Grabovica i vrijednosti za dionicu bez zona pretjecanja (za jednake ostale prometne uvjete)

\begin{tabular}{|c|c|c|c|c|c|c|c|}
\hline & \multicolumn{9}{|c|}{$\mathbf{V}_{\mathbf{0}}$} \\
\hline $\mathbf{V}_{\mathbf{d}}$ & $\begin{array}{c}\text { Bez zona } \\
\text { pret. }\end{array}$ & $\mathbf{2 0 0}$ & $\mathbf{3 0 0}$ & $\mathbf{4 0 0}$ & $\mathbf{5 0 0}$ & $\mathbf{6 0 0}$ & $\mathbf{7 0 0}$ \\
\hline $\mathbf{2 0 0}$ & $\mathbf{4 8 . 4 9}$ & $\mathbf{4 2 . 8 9}$ & 44.03 & 43.73 & 44.25 & 44.90 & 45.42 \\
\hline $\mathbf{3 0 0}$ & $\mathbf{5 7 . 8 9}$ & 53.38 & $\mathbf{5 3 . 3 8}$ & 53.71 & 54.04 & 54.59 & 55.34 \\
\hline $\mathbf{4 0 0}$ & $\mathbf{6 3 . 8 9}$ & 59.85 & 60.35 & $\mathbf{6 0 . 7 0}$ & 60.94 & 61.36 & 61.64 \\
\hline $\mathbf{5 0 0}$ & $\mathbf{6 8 . 9 5}$ & 65.44 & 65.91 & 66.22 & $\mathbf{6 6 . 4 0}$ & 66.68 & 66.92 \\
\hline $\mathbf{6 0 0}$ & $\mathbf{7 2 . 5 6}$ & 69.82 & 69.92 & 70.05 & 70.12 & $\mathbf{7 0 . 5 1}$ & 70.87 \\
\hline $\mathbf{7 0 0}$ & $\mathbf{7 5 . 4 0}$ & 72.96 & 73.05 & 73.42 & 73.52 & 73.59 & $\mathbf{7 3 . 8 6}$ \\
\hline
\end{tabular}


Tablica 6.4. Prikaz vrijednosti PTSF-a za dionicu Grabovica - Salakovac i vrijednosti za dionicu bez pretjecanja (za jednake ostale prometne uvjete)

\begin{tabular}{|c|c|c|c|c|c|c|c|}
\hline & \multicolumn{7}{|c|}{$\mathbf{V}_{\mathbf{0}}$} \\
\hline $\mathbf{V}_{\mathbf{d}}$ & $\begin{array}{c}\text { Bez zona } \\
\text { pret. }\end{array}$ & $\mathbf{2 0 0}$ & $\mathbf{3 0 0}$ & $\mathbf{4 0 0}$ & $\mathbf{5 0 0}$ & $\mathbf{6 0 0}$ & $\mathbf{7 0 0}$ \\
\hline $\mathbf{2 0 0}$ & $\mathbf{4 7 . 3 9}$ & $\mathbf{4 4 . 4 8}$ & 44.97 & 44.94 & 45.23 & 45.65 & 45.57 \\
\hline $\mathbf{3 0 0}$ & $\mathbf{5 7 . 1 4}$ & 54.43 & $\mathbf{5 4 . 8 3}$ & 54.96 & 56.38 & 55.47 & 55.42 \\
\hline $\mathbf{4 0 0}$ & $\mathbf{6 3 . 7 6}$ & 61.49 & 61.59 & $\mathbf{6 1 . 9 7}$ & 62.18 & 62.29 & 62.02 \\
\hline $\mathbf{5 0 0}$ & $\mathbf{6 8 . 5 9}$ & 66.10 & 66.34 & 66.65 & $\mathbf{6 6 . 6 8}$ & 67.00 & 67.07 \\
\hline $\mathbf{6 0 0}$ & $\mathbf{7 1 . 6 9}$ & 69.64 & 69.83 & 69.98 & 68.21 & $\mathbf{7 0 . 1 4}$ & 70.37 \\
\hline $\mathbf{7 0 0}$ & $\mathbf{7 4 . 4 8}$ & 72.36 & 72.73 & 72.79 & 72.83 & 72.92 & $\mathbf{7 3 . 2 6}$ \\
\hline
\end{tabular}

Vrijednosti PTSF-a za dionice bez pretjecanja (tablice 6.3 i 6.4) vrlo malo se razlikuju po smjerovima, što je i logično s obzirom na razlike u vrijednostima početnog $\mathrm{PTSF}_{\text {poč. }}$

Tablica 6.5. Prikaz vrijednosti PTSF-a za dionicu Salakovac - Grabovica i vrijednosti za dionicu sa zonom pretjecanja duljine $1100 \mathrm{~m}$ (za jednake ostale prometne uvjete)

\begin{tabular}{|c|c|c|c|c|c|c|c|}
\hline & \multicolumn{7}{|c|}{$V_{\mathbf{~}}$} \\
\hline $\mathbf{V}_{\mathbf{d}}$ & $\begin{array}{c}\text { Bez zona } \\
\text { pret. }\end{array}$ & $\mathbf{2 0 0}$ & $\mathbf{3 0 0}$ & $\mathbf{4 0 0}$ & $\mathbf{5 0 0}$ & $\mathbf{6 0 0}$ & $\mathbf{7 0 0}$ \\
\hline $\mathbf{2 0 0}$ & $\mathbf{4 8 . 4 9}$ & $\mathbf{4 4 . 6 5}$ & 45.16 & 45.39 & 45.60 & 45.83 & 46.10 \\
\hline $\mathbf{3 0 0}$ & $\mathbf{5 7 . 8 9}$ & 54.69 & $\mathbf{5 4 . 7 7}$ & 55.01 & 55.37 & 55.66 & 56.05 \\
\hline $\mathbf{4 0 0}$ & $\mathbf{6 3 . 8 9}$ & 61.30 & 61.45 & $\mathbf{6 1 . 5 4}$ & 62.07 & 62.10 & 62.31 \\
\hline $\mathbf{5 0 0}$ & $\mathbf{6 8 . 9 5}$ & 66.63 & 66.94 & 67.08 & $\mathbf{6 7 . 1 4}$ & 67.36 & 67.50 \\
\hline $\mathbf{6 0 0}$ & $\mathbf{7 2 . 5 6}$ & 70.52 & 70.60 & 70.71 & 70.90 & $\mathbf{7 0 . 9 8}$ & 71.37 \\
\hline $\mathbf{7 0 0}$ & $\mathbf{7 5 . 4 0}$ & 73.83 & 73.88 & 74.09 & 74.13 & 74.24 & $\mathbf{7 4 . 3 3}$ \\
\hline
\end{tabular}

Tablica 6.6. Prikaz vrijednosti PTSF-a za dionicu Grabovica - Salakovac i vrijednosti za dionicu sa zonom pretjecanja duljine $1100 \mathrm{~m}$ (za jednake ostale prometne uvjete)

\begin{tabular}{|c|c|c|c|c|c|c|c|}
\hline & \multicolumn{7}{|c|}{$V_{\mathbf{0}}$} \\
\hline $\mathbf{V}_{\mathbf{d}}$ & $\begin{array}{c}\text { Bez zona } \\
\text { pret. }\end{array}$ & $\mathbf{2 0 0}$ & $\mathbf{3 0 0}$ & $\mathbf{4 0 0}$ & $\mathbf{5 0 0}$ & $\mathbf{6 0 0}$ & $\mathbf{7 0 0}$ \\
\hline 200 & $\mathbf{4 7 . 3 9}$ & $\mathbf{4 6 . 7 3}$ & 46.82 & 46.91 & 46.95 & 47.03 & 46.95 \\
\hline 300 & $\mathbf{5 7 . 1 4}$ & 56.65 & $\mathbf{5 6 . 6 3}$ & 56.68 & 56.76 & 56.92 & 56.93 \\
\hline 400 & $\mathbf{6 3 . 7 6}$ & 63.23 & 63.28 & $\mathbf{6 3 . 4 1}$ & 63.48 & 63.58 & 63.54 \\
\hline 500 & $\mathbf{6 8 . 5 9}$ & 68.19 & 68.18 & 68.25 & $\mathbf{6 8 . 3 2}$ & 68.34 & 68.48 \\
\hline 600 & $\mathbf{7 1 . 6 9}$ & 71.21 & 71.28 & 71.35 & 71.48 & $\mathbf{7 1 . 4 5}$ & 71.50 \\
\hline 700 & $\mathbf{7 4 . 4 8}$ & 73.89 & 74.03 & 74.02 & 74.05 & 74.15 & $\mathbf{7 4 . 2 5}$ \\
\hline
\end{tabular}


Tablica 6.7. Prikaz vrijednosti PTSF-a za dionicu Salakovac - Grabovica i vrijednosti za dionicu sa zonom pretjecanja duljine $700 \mathrm{~m}$ (za jednake ostale prometne uvjete)

\begin{tabular}{|c|c|c|c|c|c|c|c|}
\hline & \multicolumn{9}{|c|}{$V_{\mathbf{~}}$} \\
\hline $\mathbf{V}_{\mathbf{d}}$ & $\begin{array}{c}\text { Bez zona } \\
\text { pret. }\end{array}$ & $\mathbf{2 0 0}$ & $\mathbf{3 0 0}$ & $\mathbf{4 0 0}$ & $\mathbf{5 0 0}$ & $\mathbf{6 0 0}$ & $\mathbf{7 0 0}$ \\
\hline $\mathbf{2 0 0}$ & $\mathbf{4 8 . 4 9}$ & $\mathbf{4 7 . 3 7}$ & 47.44 & 47.52 & 47.74 & 47.87 & 47.98 \\
\hline $\mathbf{3 0 0}$ & $\mathbf{5 7 . 8 9}$ & 56.80 & $\mathbf{5 6 . 9 0}$ & 57.07 & 57.28 & 57.50 & 57.56 \\
\hline $\mathbf{4 0 0}$ & $\mathbf{6 3 . 8 9}$ & 62.92 & 63.11 & $\mathbf{6 3 . 2 1}$ & 63.28 & 63.43 & 63.63 \\
\hline $\mathbf{5 0 0}$ & $\mathbf{6 8 . 9 5}$ & 68.13 & 68.26 & 68.28 & $\mathbf{6 8 . 4 1}$ & 68.46 & 68.61 \\
\hline $\mathbf{6 0 0}$ & $\mathbf{7 2 . 5 6}$ & 71.85 & 72.05 & 72.09 & 72.14 & $\mathbf{7 2 . 1 7}$ & 72.29 \\
\hline $\mathbf{7 0 0}$ & $\mathbf{7 5 . 4 0}$ & 74.70 & 74.82 & 74.92 & 74.98 & 74.99 & $\mathbf{7 5 . 1 6}$ \\
\hline
\end{tabular}

Tablica 6.8. Prikaz vrijednosti PTSF-a za dionicu Grabovica - Salakovac i vrijednosti za dionicu sa zonom pretjecanja duljine $700 \mathrm{~m}$ (za jednake ostale prometne uvjete)

\begin{tabular}{|c|c|c|c|c|c|c|c|}
\hline & \multicolumn{9}{|c|}{$V_{\mathbf{0}}$} \\
\hline $\mathbf{V}_{\mathbf{d}}$ & $\begin{array}{c}\text { Bez zona } \\
\text { pret. }\end{array}$ & $\mathbf{2 0 0}$ & $\mathbf{3 0 0}$ & $\mathbf{4 0 0}$ & $\mathbf{5 0 0}$ & $\mathbf{6 0 0}$ & $\mathbf{7 0 0}$ \\
\hline $\mathbf{2 0 0}$ & $\mathbf{4 7 . 3 9}$ & $\mathbf{4 5 . 6 3}$ & 45.87 & 46.14 & 46.06 & 46.09 & 46.41 \\
\hline $\mathbf{3 0 0}$ & $\mathbf{5 7 . 1 4}$ & 55.59 & $\mathbf{5 5 . 9 0}$ & 55.95 & 55.91 & 56.36 & 56.31 \\
\hline $\mathbf{4 0 0}$ & $\mathbf{6 3 . 7 6}$ & 62.50 & 62.73 & $\mathbf{6 2 . 9 6}$ & 63.06 & 63.06 & 62.95 \\
\hline $\mathbf{5 0 0}$ & $\mathbf{6 8 . 5 9}$ & 67.48 & 67.47 & 67.63 & $\mathbf{6 7 . 6 8}$ & 67.92 & 67.99 \\
\hline $\mathbf{6 0 0}$ & $\mathbf{7 1 . 6 9}$ & 70.53 & 70.82 & 70.81 & 70.94 & $\mathbf{7 0 . 9 9}$ & 71.13 \\
\hline $\mathbf{7 0 0}$ & $\mathbf{7 4 . 4 8}$ & 73.48 & 73.58 & 73.65 & 73.75 & 73.84 & $\mathbf{7 3 . 9 0}$ \\
\hline
\end{tabular}

Tablica 6.9. Prikaz vrijednosti PTSF-a za dionicu Salakovac - Grabovica i vrijednosti za dionicu s 11 zona pretjecanja duljina 400 - $450 \mathrm{~m}$ (za jednake ostale prometne uvjete)

\begin{tabular}{|c|c|c|c|c|c|c|c|}
\hline & \multicolumn{7}{|c|}{$V_{\mathbf{~}}$} \\
\hline $\mathbf{V}_{\mathbf{d}}$ & $\begin{array}{c}\text { Bez zona } \\
\text { pret. }\end{array}$ & $\mathbf{2 0 0}$ & $\mathbf{3 0 0}$ & $\mathbf{4 0 0}$ & $\mathbf{5 0 0}$ & $\mathbf{6 0 0}$ & $\mathbf{7 0 0}$ \\
\hline $\mathbf{2 0 0}$ & $\mathbf{4 8 . 4 9}$ & $\mathbf{4 5 . 3 6}$ & 46.10 & 45.73 & 46.65 & 47.13 & 47.17 \\
\hline $\mathbf{3 0 0}$ & $\mathbf{5 7 . 8 9}$ & 55.53 & $\mathbf{5 5 . 7 8}$ & 55.86 & 56.37 & 56.63 & 57.02 \\
\hline $\mathbf{4 0 0}$ & $\mathbf{6 3 . 8 9}$ & 61.88 & 62.20 & $\mathbf{6 2 . 4 0}$ & 62.63 & 62.78 & 62.86 \\
\hline $\mathbf{5 0 0}$ & $\mathbf{6 8 . 9 5}$ & 67.01 & 67.50 & 67.72 & $\mathbf{6 7 . 8 6}$ & 68.10 & 68.19 \\
\hline $\mathbf{6 0 0}$ & $\mathbf{7 2 . 5 6}$ & 70.80 & 71.07 & 71.46 & 71.56 & $\mathbf{7 1 . 7 0}$ & 71.83 \\
\hline $\mathbf{7 0 0}$ & $\mathbf{7 5 . 4 0}$ & 74.11 & 74.20 & 74.32 & 74.41 & 74.57 & $\mathbf{7 4 . 6 5}$ \\
\hline
\end{tabular}


Tablica 6.10. Prikaz vrijednosti PTSF-a za dionicu Grabovica - Salakovac i vrijednosti za dionicu s 11 zona pretjecanja duljina 400 - $450 \mathrm{~m}$ (za jednake ostale prometne uvjete)

\begin{tabular}{|c|c|c|c|c|c|c|c|}
\hline & \multicolumn{7}{|c|}{$\mathbf{V}_{\mathbf{0}}$} \\
\hline $\mathbf{V}_{\mathbf{d}}$ & $\begin{array}{c}\text { Bez zona } \\
\text { pret. }\end{array}$ & $\mathbf{2 0 0}$ & $\mathbf{3 0 0}$ & $\mathbf{4 0 0}$ & $\mathbf{5 0 0}$ & $\mathbf{6 0 0}$ & $\mathbf{7 0 0}$ \\
\hline $\mathbf{2 0 0}$ & $\mathbf{4 7 . 3 9}$ & $\mathbf{4 4 . 8 5}$ & 45.54 & 45.41 & 46.14 & 46.39 & 46.30 \\
\hline $\mathbf{3 0 0}$ & 57.14 & 55.28 & $\mathbf{5 5 . 7 0}$ & 55.73 & 56.02 & 55.76 & 56.47 \\
\hline $\mathbf{4 0 0}$ & $\mathbf{6 3 . 7 6}$ & 62.17 & 62.47 & $\mathbf{6 2 . 6 7}$ & 62.58 & 62.94 & 62.92 \\
\hline $\mathbf{5 0 0}$ & $\mathbf{6 8 . 5 9}$ & 67.18 & 66.98 & 67.44 & $\mathbf{6 7 . 4 1}$ & 67.86 & 67.85 \\
\hline $\mathbf{6 0 0}$ & $\mathbf{7 1 . 6 9}$ & 70.53 & 70.55 & 70.71 & 70.82 & $\mathbf{7 1 . 0 5}$ & 71.12 \\
\hline $\mathbf{7 0 0}$ & $\mathbf{7 4 . 4 8}$ & 73.59 & 73.49 & 73.63 & 73.63 & 73.74 & $\mathbf{7 3 . 8 5}$ \\
\hline
\end{tabular}

Razlika PTSF-a (prethodne tablice) za slučaj bez pretjecanja i slučaj pojedinačnih zona pretjecanja predstavlja direktan utjecaj pojedine zone pretjecanja na PTSF cijele dionice. Rezultati su prikazani na sljedećim grafikonima.

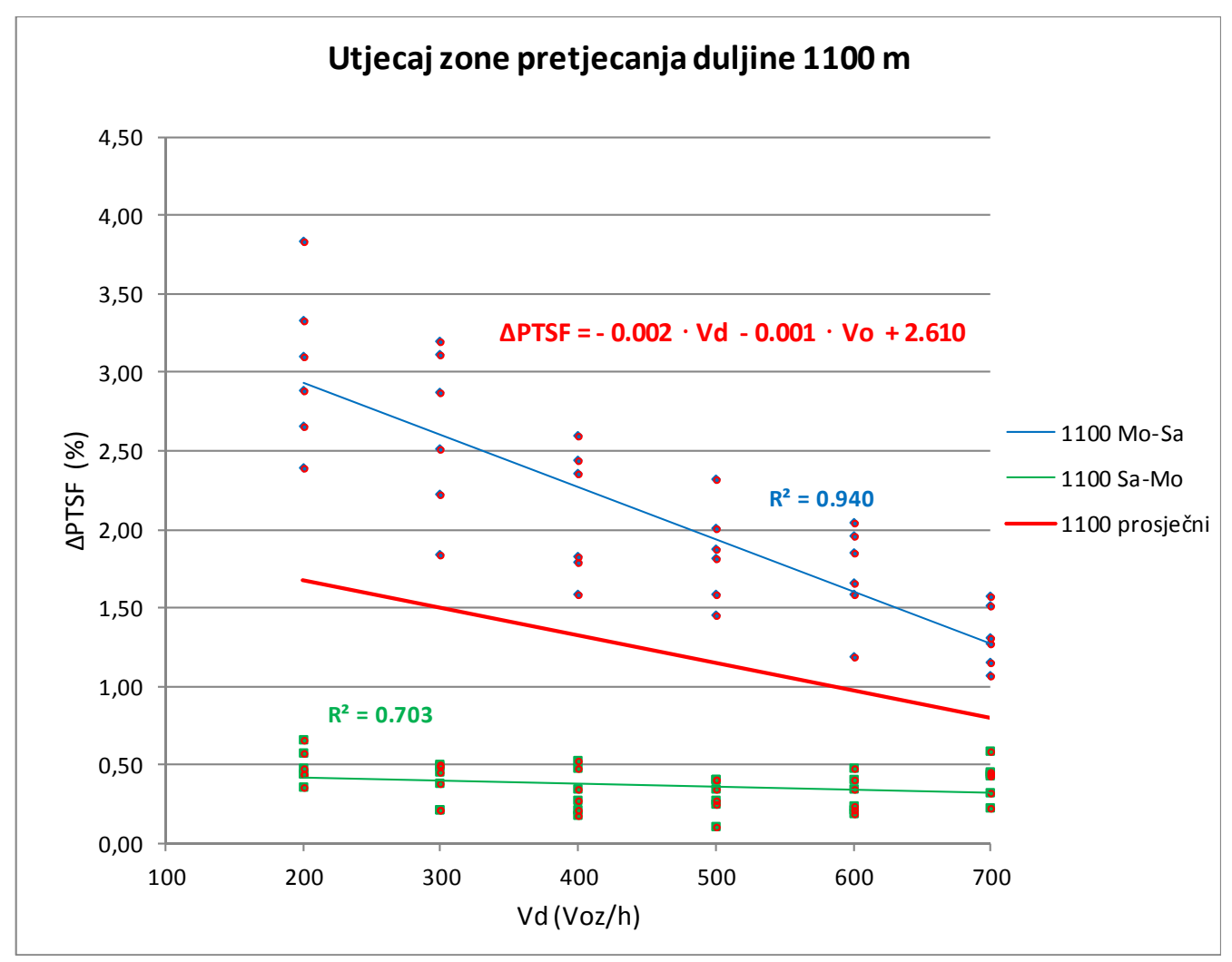

Grafikon 6.15. Utjecaj zone $1100 \mathrm{~m}\left(\mathrm{k}_{\mathrm{p}}\right)$ na PTSF za različite slučajeve opteré́enja

Rezultati na grafikonu 6.15 prikazuju oba smjera, Salakovac - Grabovica (Mo - Sa) i Grabovica - Salakovac (Sa - Mo). Za svako opterećenje analiziranog toka $V_{d}$ (od 200 voz/h do $700 \mathrm{voz} / \mathrm{h})$ dobiveno je, u ovisnosti o suprotnom toku $\mathrm{V}_{\mathrm{o}}(\mathrm{od} 200 \mathrm{voz} / \mathrm{h}$ do $700 \mathrm{voz} / \mathrm{h}), 6$ vrijednosti (točaka na grafikonu) $\triangle$ PTSF-a. S obzirom na raspršenost rezultata koji ovise o suprotnom toku, korištena je linearna regresija kojom su dobivene zakonitosti kretanja $\triangle \mathrm{PTSF}-\mathrm{a}$ 
za oba smjera i može se vidjeti dobra statistička povezanost promjene $\triangle \mathrm{PTSF}$-a s prometnim opterećenjima analiziranog i suprotnog smjera $\left(\mathrm{R}^{2}=0.703\right.$ i $\left.\mathrm{R}^{2}=0.940\right)$.

Zatim je za sve rezultate dobiven regresijski pravac definiran jednadžbom na grafikonu ( $\triangle \mathrm{PTSF})$. Može se vidjeti kako smjer Salakovac - Grabovica (Mo - Sa) ima veće vrijednosti $\triangle$ PTSF-a od suprotnog, a razlog je povoljniji položaj na dionici. Naime, zona duljine $1100 \mathrm{~m}$ smještena je na početnom dijelu ovog smjera $(2+750)$ što omogućuje iskorištavanje pozitivnog utjecaja na većoj duljini $(14.7 \mathrm{~km})$, za razliku od suprotnog smjera gdje ostaje kratka duljina za pozitivni utjecaj (svega $2.75 \mathrm{~km}$ ). Na grafikonima od 6.9 do 6.14 mogao se vidjeti nagli pad PTSF-a nakon zone pretjecanja 1100 m koji se odražava do kraja dionice.

Slična situacija je za slučaj zone pretjecanja duljine 700 m, samo je ovdje obrnut slučaj za smjerove. Veći utjecaj ima smjer Grabovica - Salakovac (SA - Mo) iz razloga povoljnijeg položaja (grafikon 6.16).

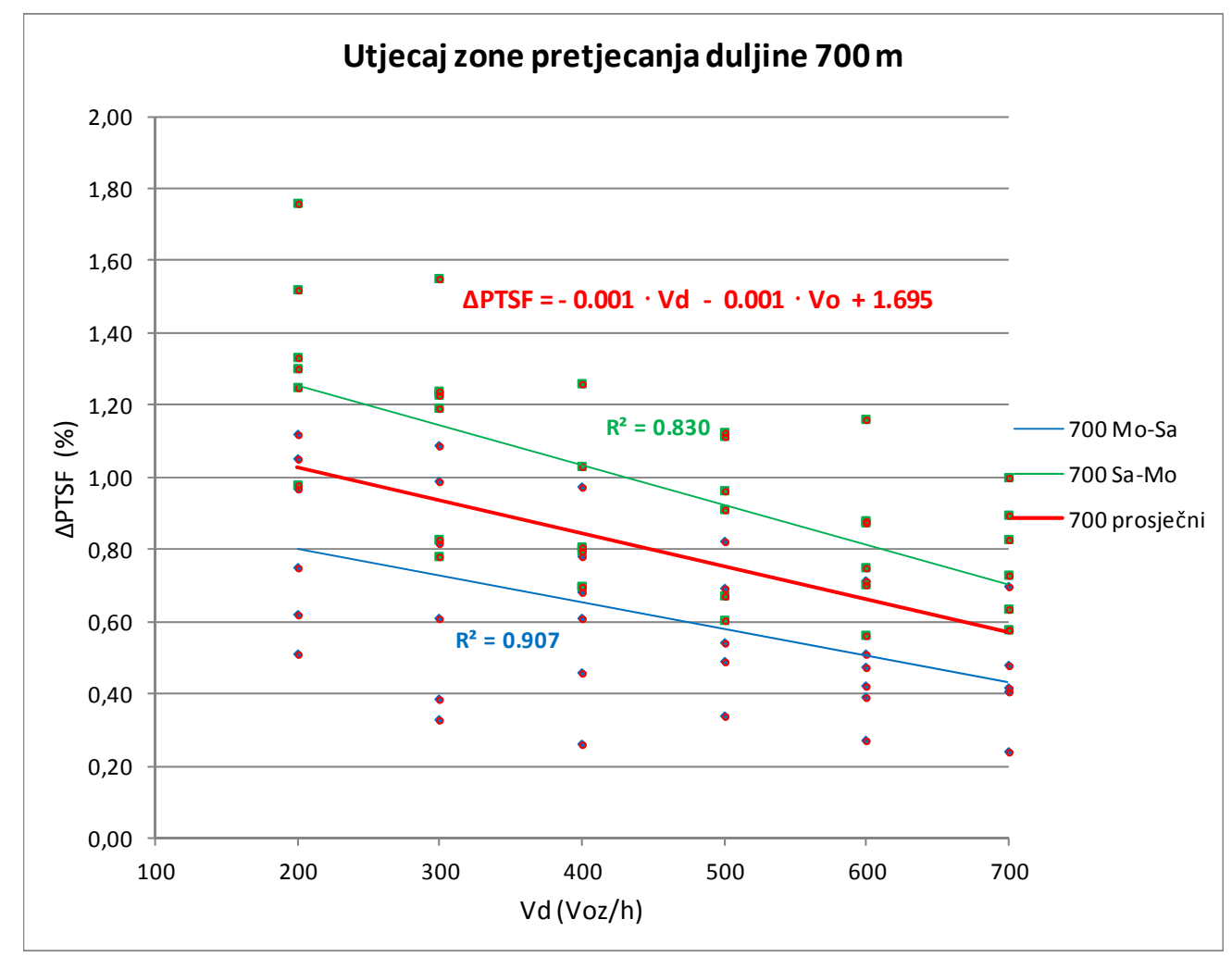

Grafikon 6.16. Utjecaj zone $700 \mathrm{~m}\left(\mathrm{k}_{\mathrm{p}}\right)$ na PTSF za različite slučajeve opterećenja

Kao što je prethodno spomenuto utjecaj zona 450 analiziran je za svih 11 zona (grafikon 6.17). Utjecaj zona 450 m vrlo je mali čak i za ovaj slučaj s 11 zona, što nije zanemariv broj jer to predstavlja slučaj od $25 \%$ duljine zona pretjecanja na dionici dok zona od $1100 \mathrm{~m}$ predstavlja oko $5 \%$ duljine dionice.

HCM ne uzima u obzir broj i duljine zona za pretjecanje nego samo ukupni \% NPZ, a to je nedovoljan parametar što pokazuju i rezultati u ovom radu. 


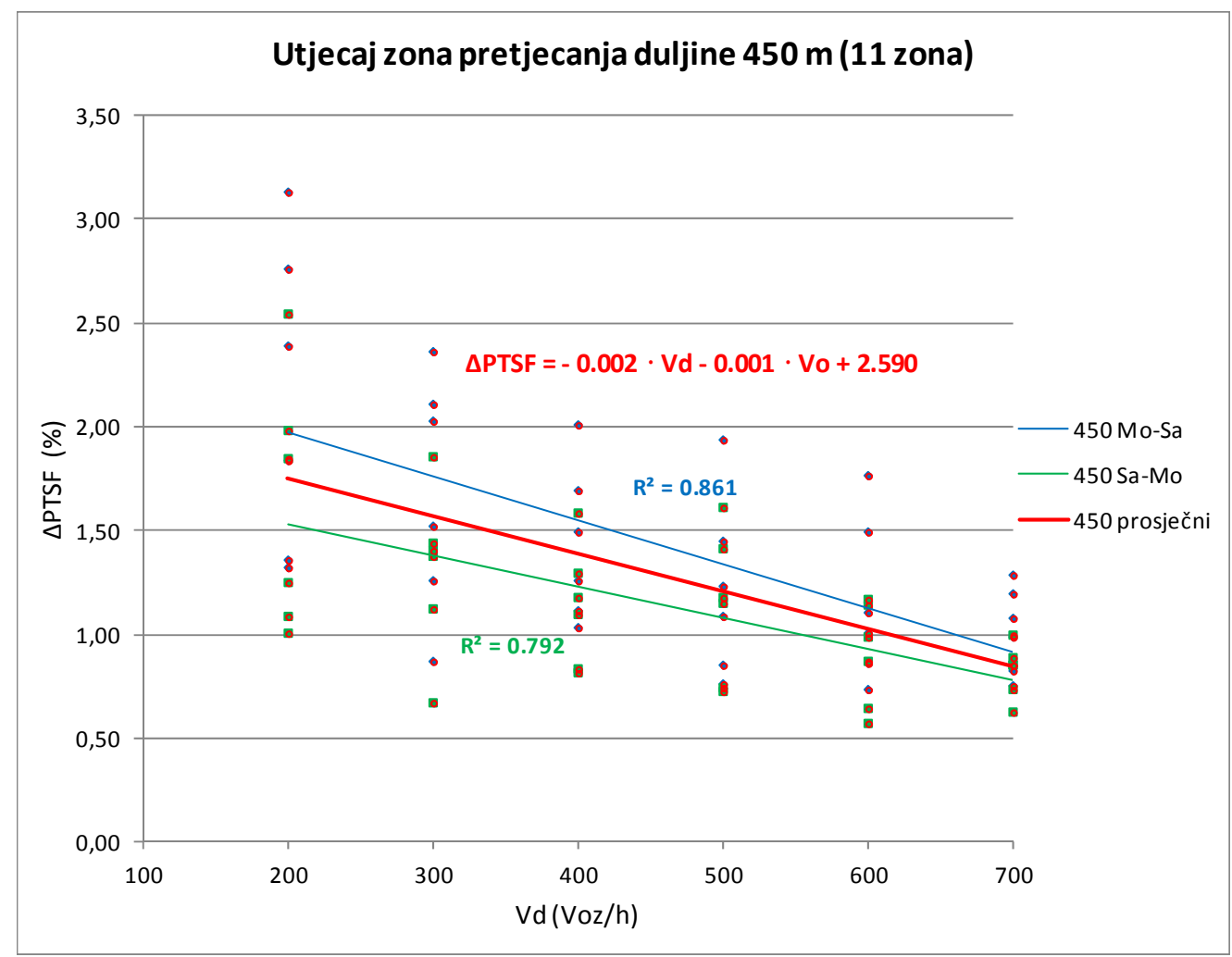

Grafikon 6.17. Utjecaj zona $450 \mathrm{~m}\left(\mathrm{k}_{\mathrm{p}}\right)$ na PTSF za različite slučajeve opterećenja

$\mathrm{Na}$ osnovu rezultata regresijske analize pojedinih zona (izrazi $\triangle \mathrm{PTSF}$ na grafikonima) definirani su grafikoni utjecaja pojedine zone u funkciji analiziranog i suprotnog toka. Ti utjecaji prikazani su na grafikonima $6.18-6.20$.

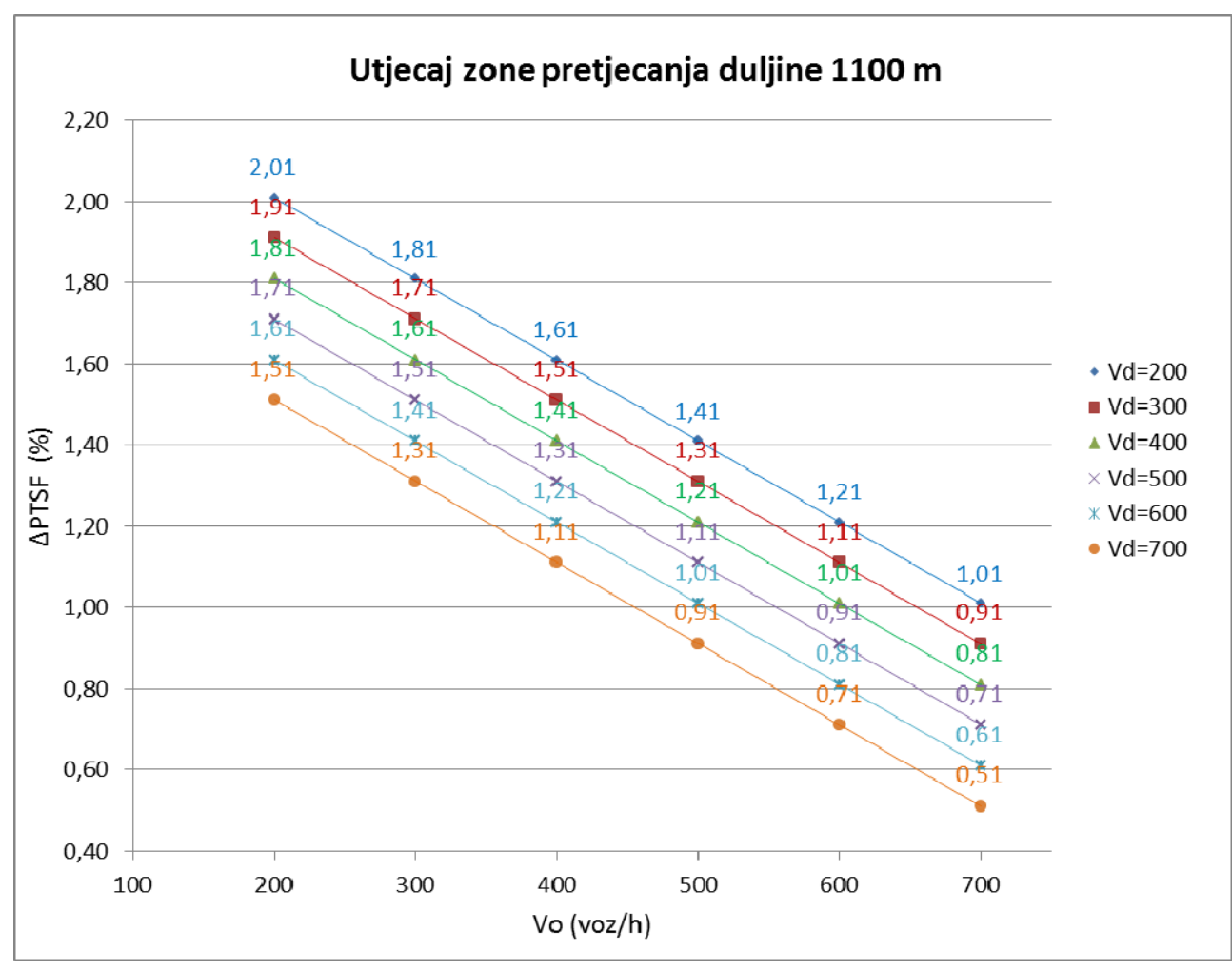

Grafikon 6.18. Utjecaj zona $1100 \mathrm{~m}\left(\mathrm{k}_{\mathrm{p}}\right)$ na PTSF dionice 


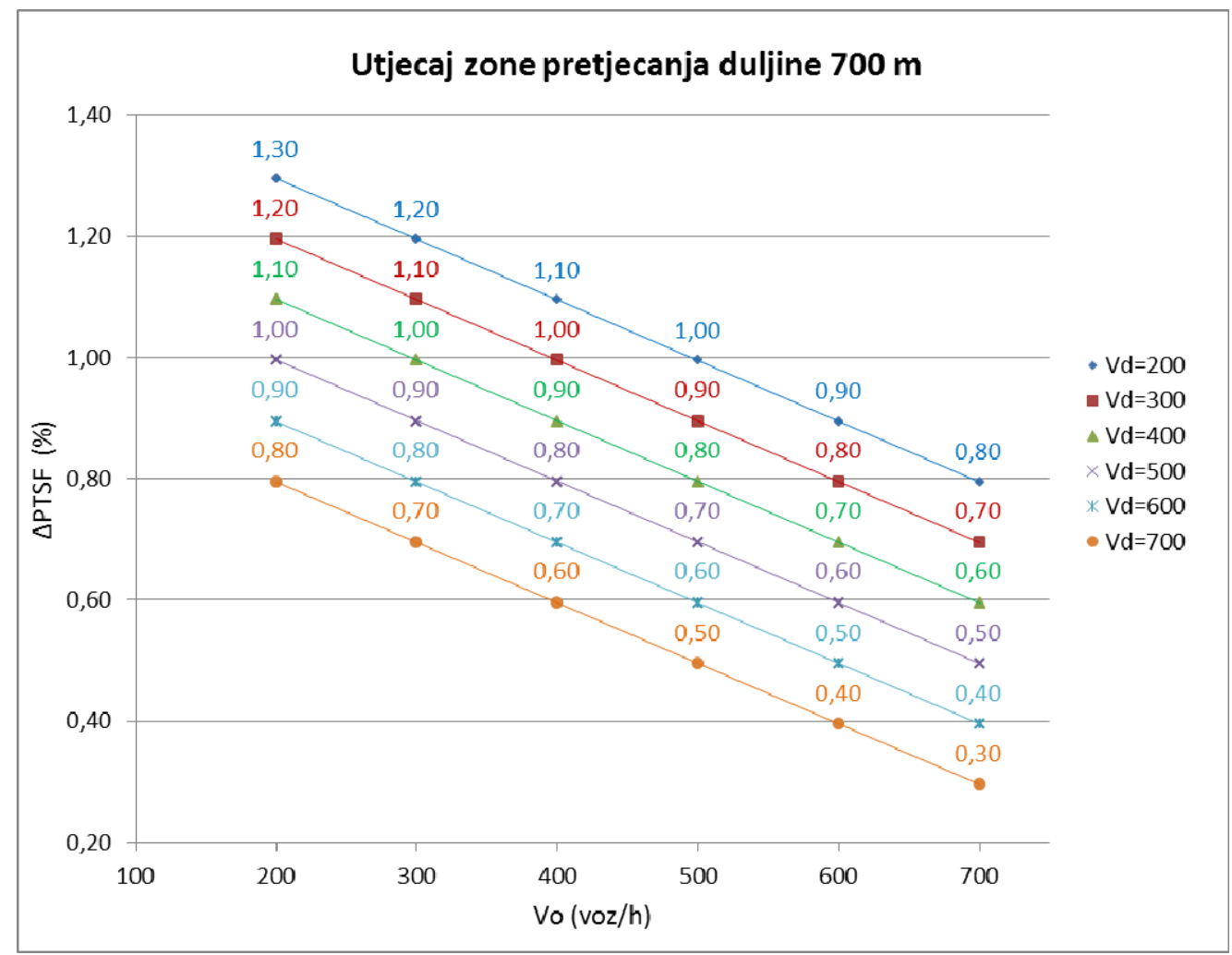

Grafikon 6.19. Utjecaj zona $700 \mathrm{~m}\left(\mathrm{k}_{\mathrm{p}}\right)$ na PTSF dionice

Za utjecaj zone $450 \mathrm{~m}$, prethodni rezultati podijeljeni su s brojem zona, a to je u ovom slučaju 11 zona.

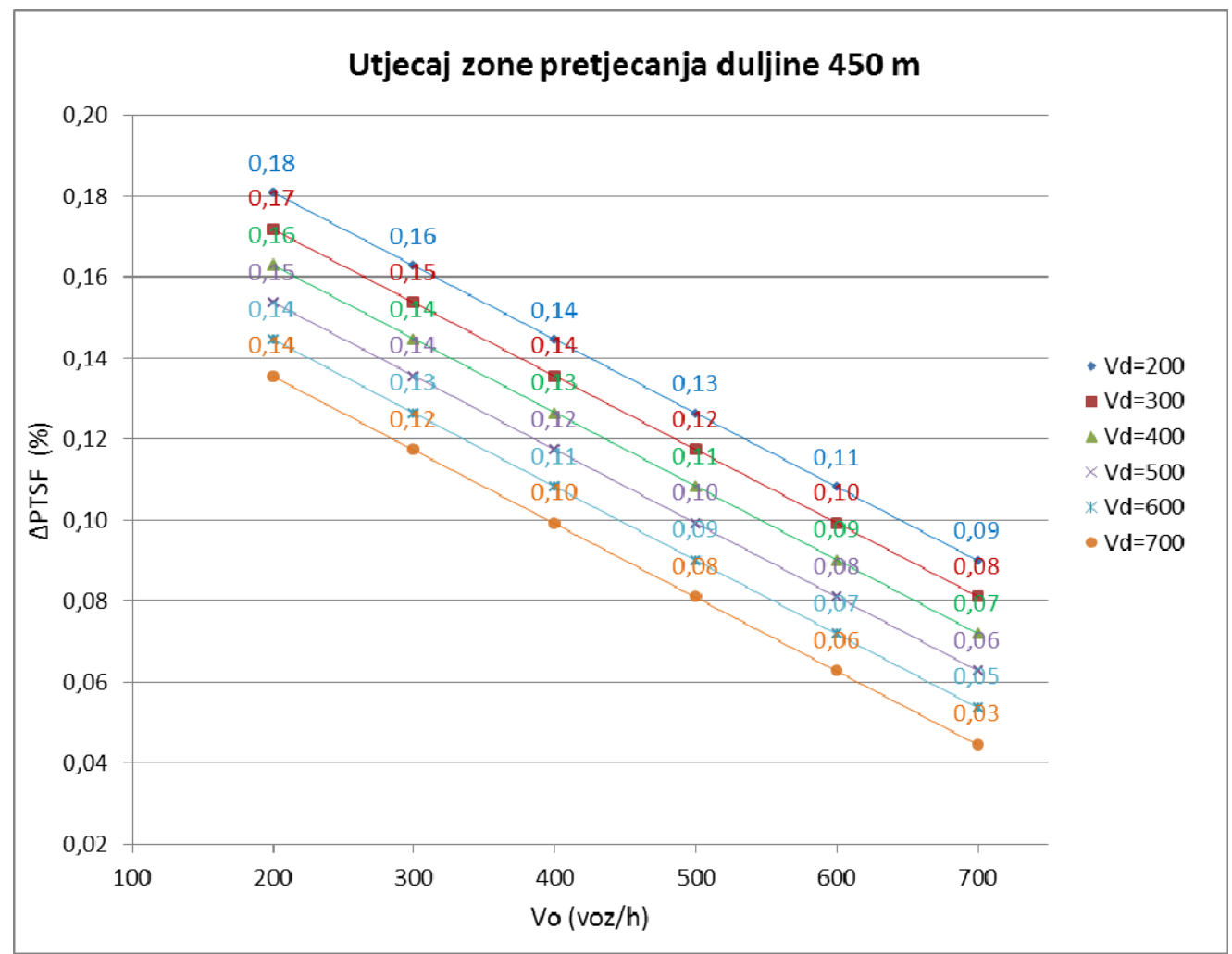

Grafikon 6.20. Utjecaj zona $450 \mathrm{~m}\left(\mathrm{k}_{\mathrm{p}}\right)$ na PTSF dionice 
$\mathrm{Na}$ temelju ovih grafikona može se direktno odrediti utjecaj zona pretjecanja $\mathrm{k}_{\mathrm{p}}$ (koji je ustvari $\triangle \mathrm{PTSF}$ ) za kombinacije opterećenja analiziranog $\mathrm{V}_{\mathrm{d}}$ i suprotnog toka $\mathrm{V}_{\mathrm{o}}$.

$\mathrm{Za}$,popunu“ područja duljina zona pretjecanja, na temelju provedenih simulacija, isti postupak je proveden za nove dionice s duljinama zona 600, 900, 1300, 1500 i $1700 \mathrm{~m}$.

U nastavku su dobiveni rezultati prikazani najprije tablično, a zatim grafički.

Tablica 6.11. Prikaz vrijednosti PTSF-a za dionicu Salakovac - Grabovica i vrijednosti za dionicu sa zonom pretjecanja duljine $600 \mathrm{~m}$ (za jednake ostale prometne uvjete)

\begin{tabular}{|c|c|c|c|c|c|c|c|}
\hline & \multicolumn{5}{|c|}{$\mathbf{V}_{\mathbf{0}}$} \\
\hline $\mathbf{V}_{\mathbf{d}}$ & $\begin{array}{c}\text { Bez zona } \\
\text { pret. }\end{array}$ & $\mathbf{2 0 0}$ & $\mathbf{3 0 0}$ & $\mathbf{4 0 0}$ & $\mathbf{5 0 0}$ & $\mathbf{6 0 0}$ & $\mathbf{7 0 0}$ \\
\hline $\mathbf{2 0 0}$ & $\mathbf{4 8 . 4 9}$ & $\mathbf{4 7 . 4 3}$ & 47.59 & 47.65 & 47.91 & 47.94 & 48.16 \\
\hline $\mathbf{3 0 0}$ & 57.89 & 56.91 & $\mathbf{5 7 . 1 1}$ & 57.14 & 57.43 & 57.56 & 57.68 \\
\hline $\mathbf{4 0 0}$ & $\mathbf{6 3 . 8 9}$ & 63.11 & 63.23 & $\mathbf{6 3 . 3 7}$ & 63.37 & 63.59 & 63.62 \\
\hline $\mathbf{5 0 0}$ & $\mathbf{6 8 . 9 5}$ & 68.28 & 68.40 & 68.45 & $\mathbf{6 8 . 4 9}$ & 68.55 & 68.65 \\
\hline $\mathbf{6 0 0}$ & $\mathbf{7 2 . 5 6}$ & 71.79 & 72.15 & 72.20 & 72.24 & $\mathbf{7 2 . 2 5}$ & 72.33 \\
\hline $\mathbf{7 0 0}$ & $\mathbf{7 5 . 4 0}$ & 74.85 & 74.91 & 74.97 & 75.05 & 75.05 & $\mathbf{7 5 . 2 2}$ \\
\hline
\end{tabular}

Tablica 6.12. Prikaz vrijednosti PTSF-a za dionicu Grabovica - Salakovac i vrijednosti za dionicu sa zonom pretjecanja duljine $600 \mathrm{~m}$ (za jednake ostale prometne uvjete)

\begin{tabular}{|c|c|c|c|c|c|c|c|}
\hline & \multicolumn{7}{|c|}{$V_{\mathbf{~}}$} \\
\hline $\mathbf{V}_{\mathbf{d}}$ & $\begin{array}{c}\text { Bezzona } \\
\text { pret. }\end{array}$ & $\mathbf{2 0 0}$ & $\mathbf{3 0 0}$ & $\mathbf{4 0 0}$ & $\mathbf{5 0 0}$ & $\mathbf{6 0 0}$ & $\mathbf{7 0 0}$ \\
\hline $\mathbf{2 0 0}$ & $\mathbf{4 7 . 3 9}$ & $\mathbf{4 5 . 8 6}$ & 46.14 & 46.13 & 46.23 & 46.52 & 46.62 \\
\hline $\mathbf{3 0 0}$ & $\mathbf{5 7 . 1 4}$ & 55.88 & $\mathbf{5 6 . 1 5}$ & 56.10 & 56.33 & 56.48 & 56.45 \\
\hline $\mathbf{4 0 0}$ & $\mathbf{6 3 . 7 6}$ & 62.62 & 63.00 & $\mathbf{6 3 . 0 6}$ & 63.08 & 63.14 & 63.14 \\
\hline $\mathbf{5 0 0}$ & $\mathbf{6 8 . 5 9}$ & 67.69 & 67.65 & 67.77 & $\mathbf{6 7 . 9 4}$ & 68.06 & 68.10 \\
\hline $\mathbf{6 0 0}$ & $\mathbf{7 1 . 6 9}$ & 70.66 & 70.95 & 71.07 & 71.06 & $\mathbf{7 1 . 1 0}$ & 71.19 \\
\hline $\mathbf{7 0 0}$ & $\mathbf{7 4 . 4 8}$ & 73.59 & 73.69 & 73.84 & 73.89 & 73.96 & $\mathbf{7 3 . 9 6}$ \\
\hline
\end{tabular}

Tablica 6.13. Prikaz vrijednosti PTSF-a za dionicu Salakovac - Grabovica i vrijednosti za dionicu sa zonom pretjecanja duljine $900 \mathrm{~m}$ (za jednake ostale prometne uvjete)

\begin{tabular}{|c|c|c|c|c|c|c|c|}
\hline & \multicolumn{7}{|c|}{$V_{\mathbf{~}}$} \\
\hline $\mathbf{V}_{\mathbf{d}}$ & $\begin{array}{c}\text { Bezzona } \\
\text { pret. }\end{array}$ & $\mathbf{2 0 0}$ & $\mathbf{3 0 0}$ & $\mathbf{4 0 0}$ & $\mathbf{5 0 0}$ & $\mathbf{6 0 0}$ & $\mathbf{7 0 0}$ \\
\hline $\mathbf{2 0 0}$ & $\mathbf{4 8 . 4 9}$ & $\mathbf{4 6 . 6 0}$ & 46.62 & 46.95 & 47.19 & 47.40 & 47.76 \\
\hline $\mathbf{3 0 0}$ & $\mathbf{5 7 . 8 9}$ & 56.31 & $\mathbf{5 6 . 5 3}$ & 56.70 & 56.86 & 57.14 & 57.32 \\
\hline $\mathbf{4 0 0}$ & $\mathbf{6 3 . 8 9}$ & 62.70 & 62.71 & $\mathbf{6 2 . 9 2}$ & 63.02 & 63.25 & 63.36 \\
\hline $\mathbf{5 0 0}$ & $\mathbf{6 8 . 9 5}$ & 67.85 & 68.04 & 68.08 & $\mathbf{6 8 . 1 5}$ & 68.29 & 68.51 \\
\hline $\mathbf{6 0 0}$ & $\mathbf{7 2 . 5 6}$ & 71.56 & 71.71 & 71.87 & 71.96 & $\mathbf{7 2 . 0 3}$ & 72.09 \\
\hline $\mathbf{7 0 0}$ & $\mathbf{7 5 . 4 0}$ & 74.59 & 74.56 & 74.69 & 74.77 & 74.84 & $\mathbf{7 4 . 9 7}$ \\
\hline
\end{tabular}


Tablica 6.14. Prikaz vrijednosti PTSF-a za dionicu Grabovica - Salakovac i vrijednosti za dionicu sa zonom pretjecanja duljine $900 \mathrm{~m}$ (za jednake ostale prometne uvjete)

\begin{tabular}{|c|c|c|c|c|c|c|c|}
\hline & \multicolumn{7}{|c|}{$\mathbf{V}_{\mathbf{0}}$} \\
\hline $\mathbf{V}_{\mathbf{d}}$ & $\begin{array}{c}\text { Bez zona } \\
\text { pret. }\end{array}$ & $\mathbf{2 0 0}$ & $\mathbf{3 0 0}$ & $\mathbf{4 0 0}$ & $\mathbf{5 0 0}$ & $\mathbf{6 0 0}$ & $\mathbf{7 0 0}$ \\
\hline $\mathbf{2 0 0}$ & 47.39 & $\mathbf{4 5 . 3 1}$ & 45.42 & 45.57 & 45.81 & 45.87 & 45.93 \\
\hline $\mathbf{3 0 0}$ & 57.14 & 55.21 & $\mathbf{5 5 . 5 4}$ & 55.61 & 55.69 & 55.79 & 55.97 \\
\hline $\mathbf{4 0 0}$ & 63.76 & 62.17 & 62.27 & $\mathbf{6 2 . 3 2}$ & 62.53 & 62.67 & 62.75 \\
\hline $\mathbf{5 0 0}$ & 68.59 & 67.11 & 67.24 & 67.29 & $\mathbf{6 7 . 3 5}$ & 67.74 & 67.69 \\
\hline $\mathbf{6 0 0}$ & 71.69 & 70.33 & 70.47 & 70.54 & 70.80 & $\mathbf{7 0 . 7 6}$ & 70.88 \\
\hline $\mathbf{7 0 0}$ & 74.48 & 73.29 & 73.53 & 73.48 & 73.65 & 73.69 & $\mathbf{7 3 . 7 8}$ \\
\hline
\end{tabular}

Tablica 6.15. Prikaz vrijednosti PTSF-a za dionicu Salakovac - Grabovica i vrijednosti za dionicu sa zonom pretjecanja duljine $1300 \mathrm{~m}$ (za jednake ostale prometne uvjete)

\begin{tabular}{|c|c|c|c|c|c|c|c|}
\hline & \multicolumn{9}{|c|}{$V_{\mathbf{0}}$} \\
\hline $\mathbf{V}_{\mathbf{d}}$ & $\begin{array}{c}\text { Bez zona } \\
\text { pret. }\end{array}$ & $\mathbf{2 0 0}$ & $\mathbf{3 0 0}$ & $\mathbf{4 0 0}$ & $\mathbf{5 0 0}$ & $\mathbf{6 0 0}$ & $\mathbf{7 0 0}$ \\
\hline $\mathbf{2 0 0}$ & $\mathbf{4 8 . 4 9}$ & $\mathbf{4 4 . 4 5}$ & 44.83 & 45.05 & 45.36 & 45.63 & 46.03 \\
\hline $\mathbf{3 0 0}$ & $\mathbf{5 7 . 8 9}$ & 54.46 & $\mathbf{5 4 . 4 7}$ & 54.93 & 54.78 & 55.35 & 55.89 \\
\hline $\mathbf{4 0 0}$ & $\mathbf{6 3 . 8 9}$ & 61.10 & 61.39 & $\mathbf{6 1 . 3 8}$ & 61.54 & 61.94 & 62.15 \\
\hline $\mathbf{5 0 0}$ & $\mathbf{6 8 . 9 5}$ & 66.55 & 66.82 & 67.03 & $\mathbf{6 7 . 0 0}$ & 67.24 & 67.29 \\
\hline $\mathbf{6 0 0}$ & $\mathbf{7 2 . 5 6}$ & 70.44 & 70.66 & 70.57 & 70.79 & $\mathbf{7 0 . 8 0}$ & 71.24 \\
\hline $\mathbf{7 0 0}$ & $\mathbf{7 5 . 4 0}$ & 73.74 & 73.69 & 73.94 & 73.95 & 74.16 & $\mathbf{7 4 . 1 6}$ \\
\hline
\end{tabular}

Tablica 6.16. Prikaz vrijednosti PTSF-a za dionicu Grabovica - Salakovac i vrijednosti za dionicu sa zonom pretjecanja duljine $1300 \mathrm{~m}$ (za jednake ostale prometne uvjete)

\begin{tabular}{|c|c|c|c|c|c|c|c|}
\hline & \multicolumn{7}{|c|}{$V_{\mathbf{~}}$} \\
\hline $\mathbf{V}_{\mathbf{d}}$ & $\begin{array}{c}\text { Bezzona } \\
\text { pret. }\end{array}$ & $\mathbf{2 0 0}$ & $\mathbf{3 0 0}$ & $\mathbf{4 0 0}$ & $\mathbf{5 0 0}$ & $\mathbf{6 0 0}$ & $\mathbf{7 0 0}$ \\
\hline $\mathbf{2 0 0}$ & 47.39 & $\mathbf{4 6 . 6 9}$ & 46.78 & 46.87 & 46.91 & 46.99 & 46.91 \\
\hline $\mathbf{3 0 0}$ & 57.14 & 56.61 & $\mathbf{5 6 . 5 9}$ & 56.64 & 56.72 & 56.88 & 56.89 \\
\hline $\mathbf{4 0 0}$ & 63.76 & 63.19 & 63.24 & $\mathbf{6 3 . 3 7}$ & 63.44 & 63.54 & 63.50 \\
\hline $\mathbf{5 0 0}$ & 68.59 & 68.15 & 68.14 & 68.21 & $\mathbf{6 8 . 2 8}$ & 68.30 & 68.44 \\
\hline $\mathbf{6 0 0}$ & 71.69 & 71.17 & 71.24 & 71.31 & 71.44 & $\mathbf{7 1 . 4 1}$ & 71.46 \\
\hline $\mathbf{7 0 0}$ & 74.48 & 73.85 & 73.99 & 73.98 & 74.01 & 74.11 & $\mathbf{7 4 . 2 1}$ \\
\hline
\end{tabular}


Tablica 6.17. Prikaz vrijednosti PTSF-a za dionicu Salakovac - Grabovica i vrijednosti za dionicu sa zonom pretjecanja duljine $1500 \mathrm{~m}$ (za jednake ostale prometne uvjete)

\begin{tabular}{|c|c|c|c|c|c|c|c|}
\hline & \multicolumn{7}{|c|}{$\mathbf{V}_{\mathbf{0}}$} \\
\hline $\mathbf{V}_{\mathbf{d}}$ & $\begin{array}{c}\text { Bez zona } \\
\text { pret. }\end{array}$ & $\mathbf{2 0 0}$ & $\mathbf{3 0 0}$ & $\mathbf{4 0 0}$ & $\mathbf{5 0 0}$ & $\mathbf{6 0 0}$ & $\mathbf{7 0 0}$ \\
\hline $\mathbf{2 0 0}$ & $\mathbf{4 8 . 4 9}$ & $\mathbf{4 4 . 3 7}$ & 44.18 & 44.92 & 45.23 & 45.47 & 46.06 \\
\hline $\mathbf{3 0 0}$ & $\mathbf{5 7 . 8 9}$ & 54.16 & $\mathbf{5 4 . 2 9}$ & 54.62 & 54.57 & 55.19 & 55.58 \\
\hline $\mathbf{4 0 0}$ & $\mathbf{6 3 . 8 9}$ & 61.13 & 61.09 & $\mathbf{6 1 . 2 2}$ & 61.33 & 61.67 & 61.84 \\
\hline $\mathbf{5 0 0}$ & $\mathbf{6 8 . 9 5}$ & 66.48 & 66.60 & 66.99 & $\mathbf{6 7 . 0 3}$ & 67.06 & 67.14 \\
\hline $\mathbf{6 0 0}$ & $\mathbf{7 2 . 5 6}$ & 70.37 & 70.53 & 70.52 & 70.63 & $\mathbf{7 0 . 6 6}$ & 71.06 \\
\hline $\mathbf{7 0 0}$ & $\mathbf{7 5 . 4 0}$ & 73.66 & 73.59 & 73.77 & 73.88 & 74.05 & $\mathbf{7 4 . 1 4}$ \\
\hline
\end{tabular}

Tablica 6.18. Prikaz vrijednosti PTSF-a za dionicu Grabovica - Salakovac i vrijednosti za dionicu sa zonom pretjecanja duljine $1500 \mathrm{~m}$ (za jednake ostale prometne uvjete)

\begin{tabular}{|c|c|c|c|c|c|c|c|}
\hline & \multicolumn{9}{|c|}{$V_{\mathbf{0}}$} \\
\hline $\mathbf{V}_{\mathbf{d}}$ & $\begin{array}{c}\text { Bez zona } \\
\text { pret. }\end{array}$ & $\mathbf{2 0 0}$ & $\mathbf{3 0 0}$ & $\mathbf{4 0 0}$ & $\mathbf{5 0 0}$ & $\mathbf{6 0 0}$ & $\mathbf{7 0 0}$ \\
\hline $\mathbf{2 0 0}$ & 47.39 & $\mathbf{4 6 . 7 1}$ & 46.71 & 46.88 & 46.90 & 46.94 & 46.89 \\
\hline $\mathbf{3 0 0}$ & 57.14 & 56.59 & $\mathbf{5 6 . 6 0}$ & 56.63 & 56.71 & 56.88 & 56.90 \\
\hline $\mathbf{4 0 0}$ & 63.76 & 63.18 & 63.26 & $\mathbf{6 3 . 3 8}$ & 63.43 & 63.50 & 63.50 \\
\hline $\mathbf{5 0 0}$ & 68.59 & 68.16 & 68.14 & 68.20 & $\mathbf{6 8 . 2 3}$ & 68.28 & 68.44 \\
\hline $\mathbf{6 0 0}$ & 71.69 & 71.18 & 71.22 & 71.33 & 71.43 & $\mathbf{7 1 . 4 0}$ & 71.44 \\
\hline $\mathbf{7 0 0}$ & 74.48 & 73.84 & 73.98 & 73.97 & 74.01 & 74.10 & $\mathbf{7 4 . 2 1}$ \\
\hline
\end{tabular}

Tablica 6.19. Prikaz vrijednosti PTSF-a za dionicu Salakovac - Grabovica i vrijednosti za dionicu sa zonom pretjecanja duljine $1700 \mathrm{~m}$ (za jednake ostale prometne uvjete)

\begin{tabular}{|c|c|c|c|c|c|c|c|}
\hline & \multicolumn{7}{|c|}{$V_{\mathbf{~}}$} \\
\hline $\mathbf{V}_{\mathbf{d}}$ & $\begin{array}{c}\text { Bezzona } \\
\text { pret. }\end{array}$ & $\mathbf{2 0 0}$ & $\mathbf{3 0 0}$ & $\mathbf{4 0 0}$ & $\mathbf{5 0 0}$ & $\mathbf{6 0 0}$ & $\mathbf{7 0 0}$ \\
\hline $\mathbf{2 0 0}$ & $\mathbf{4 8 . 4 9}$ & $\mathbf{4 4 . 2 6}$ & 44.19 & 44.79 & 44.96 & 45.11 & 45.90 \\
\hline $\mathbf{3 0 0}$ & $\mathbf{5 7 . 8 9}$ & 54.70 & $\mathbf{5 4 . 1 8}$ & 54.70 & 54.49 & 54.94 & 55.37 \\
\hline $\mathbf{4 0 0}$ & $\mathbf{6 3 . 8 9}$ & 61.04 & 60.97 & $\mathbf{6 1 . 1 1}$ & 61.21 & 61.45 & 61.62 \\
\hline $\mathbf{5 0 0}$ & $\mathbf{6 8 . 9 5}$ & 66.40 & 66.52 & 66.79 & $\mathbf{6 6 . 7 4}$ & 67.04 & 67.10 \\
\hline $\mathbf{6 0 0}$ & $\mathbf{7 2 . 5 6}$ & 70.32 & 70.40 & 70.49 & 70.55 & $\mathbf{7 0 . 6 0}$ & 70.80 \\
\hline $\mathbf{7 0 0}$ & $\mathbf{7 5 . 4 0}$ & 73.61 & 73.59 & 73.70 & 73.82 & 73.97 & $\mathbf{7 4 . 1 1}$ \\
\hline
\end{tabular}


Tablica 6.20. Prikaz vrijednosti PTSF-a za dionicu Grabovica - Salakovac i vrijednosti za dionicu sa zonom pretjecanja duljine $1700 \mathrm{~m}$ (za jednake ostale prometne uvjete)

\begin{tabular}{|c|c|c|c|c|c|c|c|}
\hline & \multicolumn{9}{|c|}{$V_{\mathbf{o}}$} \\
\hline $\mathbf{V}_{\mathbf{d}}$ & $\begin{array}{c}\text { Bez zona } \\
\text { pret. }\end{array}$ & $\mathbf{2 0 0}$ & $\mathbf{3 0 0}$ & $\mathbf{4 0 0}$ & $\mathbf{5 0 0}$ & $\mathbf{6 0 0}$ & $\mathbf{7 0 0}$ \\
\hline $\mathbf{2 0 0}$ & 47.39 & $\mathbf{4 6 . 6 8}$ & 46.70 & 46.82 & 46.90 & 46.91 & 46.88 \\
\hline $\mathbf{3 0 0}$ & 57.14 & 56.61 & $\mathbf{5 6 . 5 6}$ & 56.63 & 56.70 & 56.87 & 56.88 \\
\hline $\mathbf{4 0 0}$ & 63.76 & 63.20 & 63.27 & $\mathbf{6 3 . 3 6}$ & 63.42 & 63.51 & 63.49 \\
\hline $\mathbf{5 0 0}$ & 68.59 & 68.15 & 68.12 & 68.19 & $\mathbf{6 8 . 2 6}$ & 68.27 & 68.42 \\
\hline $\mathbf{6 0 0}$ & 71.69 & 71.16 & 71.21 & 71.31 & 71.41 & $\mathbf{7 1 . 3 8}$ & 71.44 \\
\hline $\mathbf{7 0 0}$ & 74.48 & 73.84 & 73.98 & 73.98 & 74.00 & 74.09 & $\mathbf{7 4 . 2 0}$ \\
\hline
\end{tabular}

$\mathrm{Na}$ temelju rezultata $\mathrm{u}$ prethodnim tablicama dobiveni su grafikoni promjene PTSF-a ( $\triangle \mathrm{PTSF}$ ) po smjerovima (grafikoni 6.21 - 6.25).

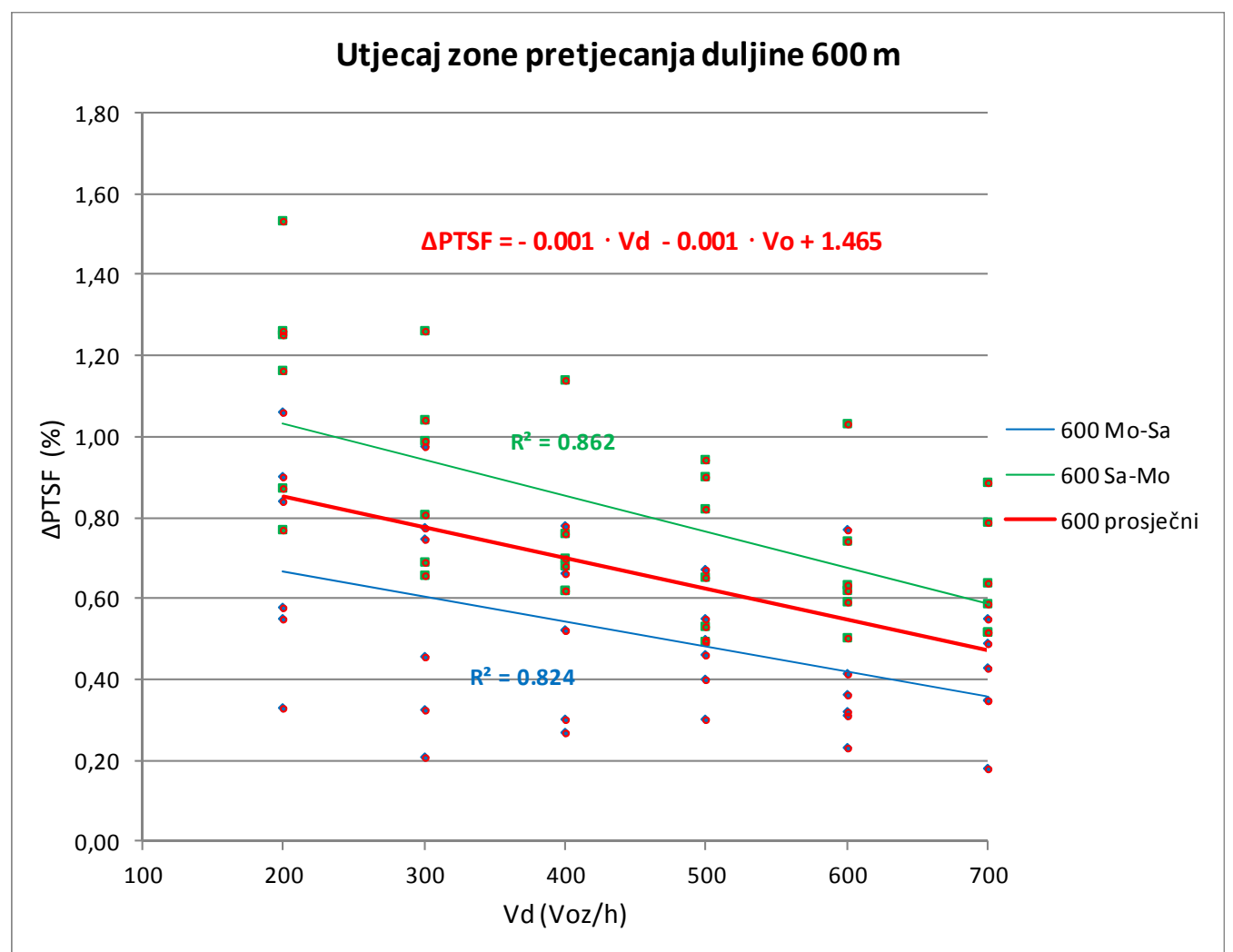

Grafikon 6.21. Utjecaj zone $600 \mathrm{~m}\left(\mathrm{k}_{\mathrm{p}}\right)$ na PTSF za različite slučajeve opterećenja 


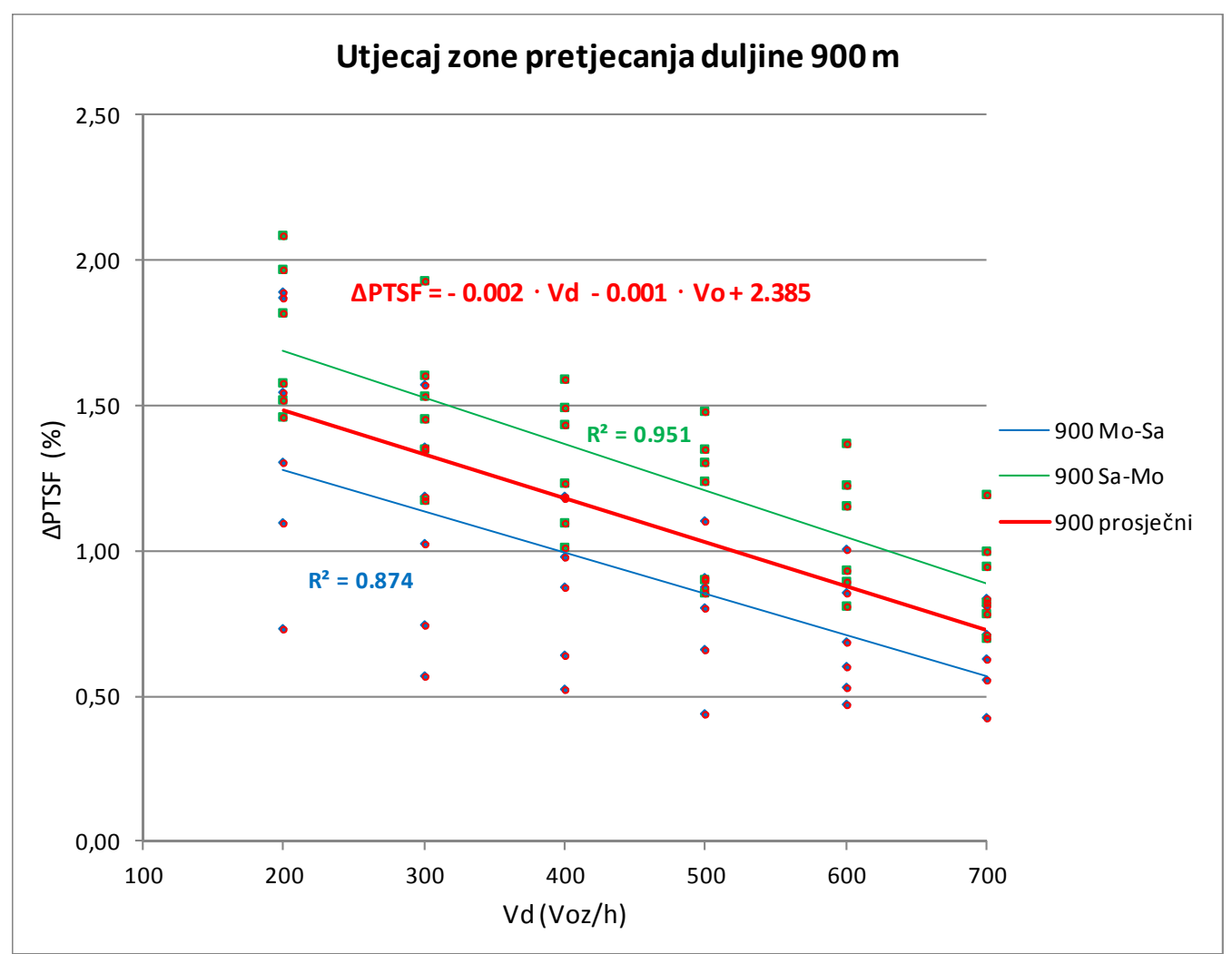

Grafikon 6.22. Utjecaj zone $900 \mathrm{~m}\left(\mathrm{k}_{\mathrm{p}}\right)$ na PTSF za različite slučajeve opterećenja

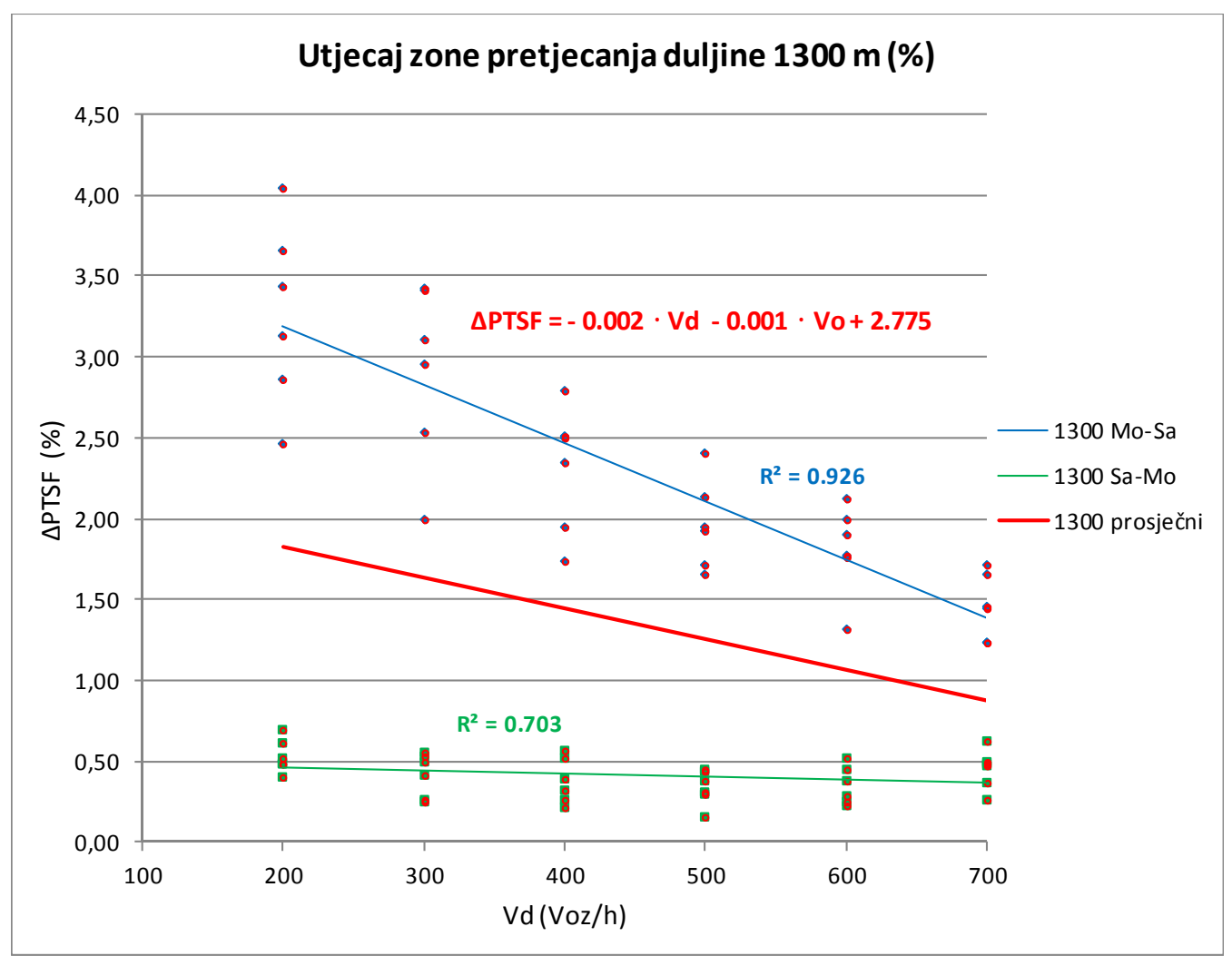

Grafikon 6.23. Utjecaj zone $1300 \mathrm{~m}\left(\mathrm{k}_{\mathrm{p}}\right)$ na PTSF za različite slučajeve opterećenja 


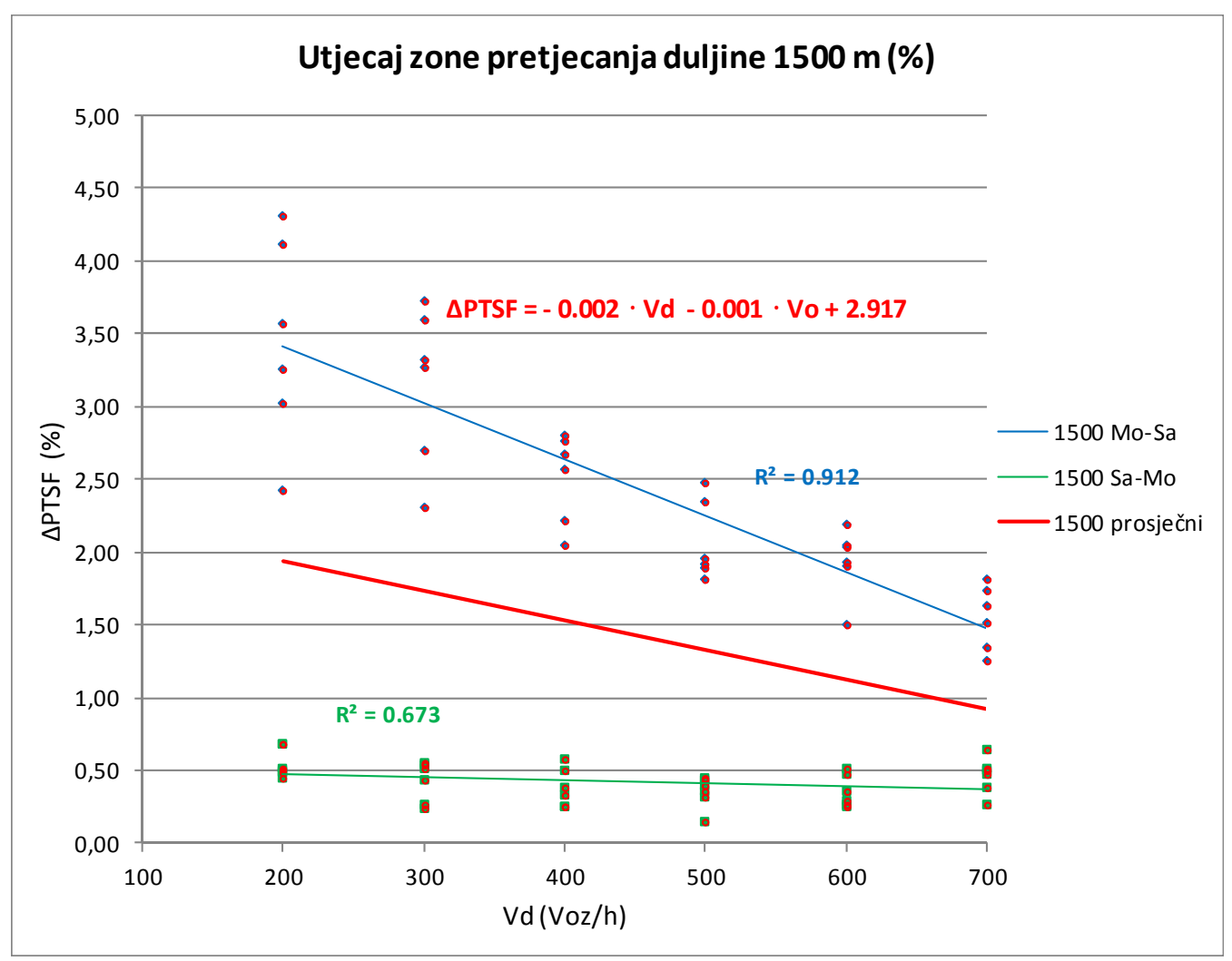

Grafikon 6.24. Utjecaj zone $1500 \mathrm{~m}\left(\mathrm{k}_{\mathrm{p}}\right)$ na PTSF za različite slučajeve opterećenja

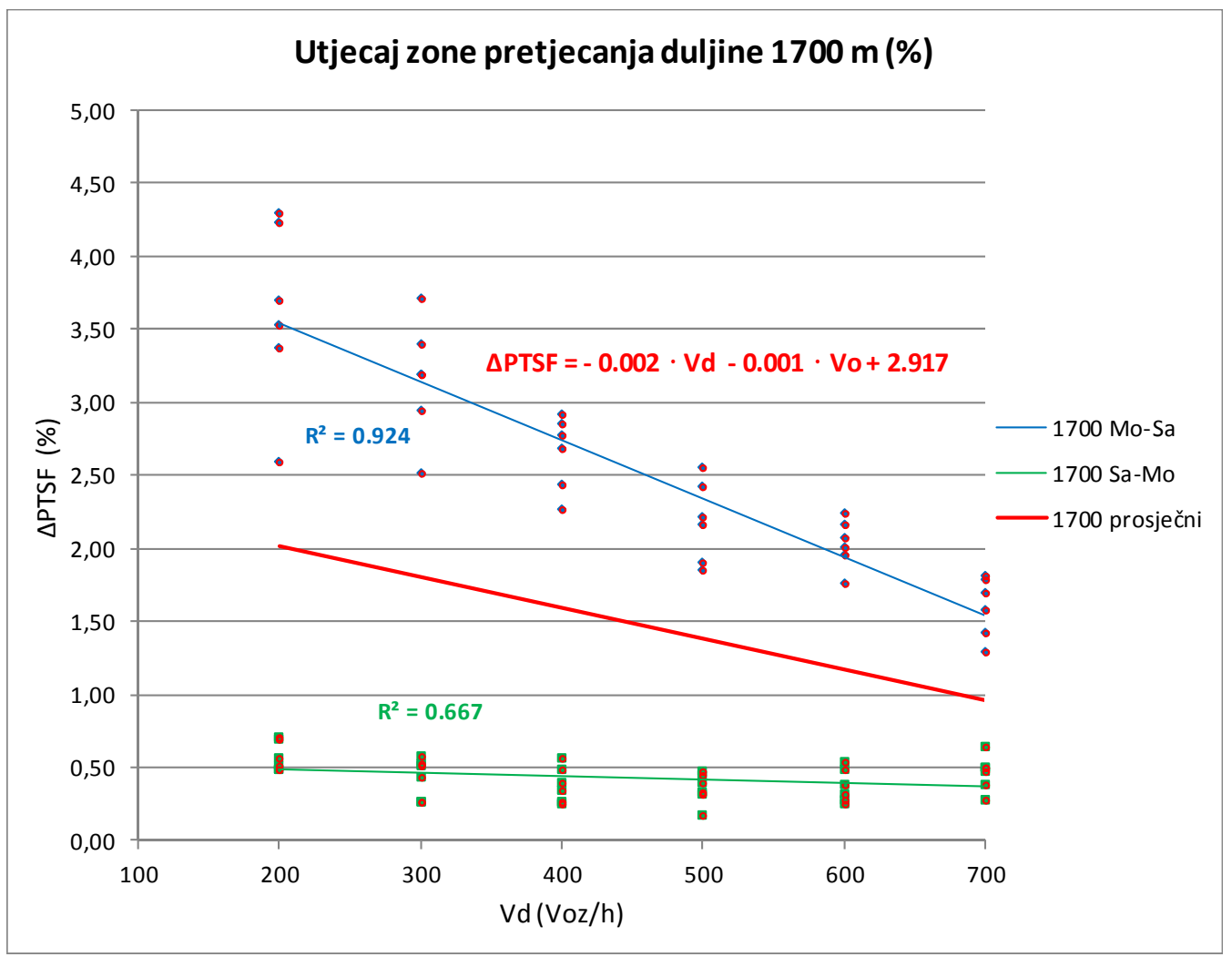

Grafikon 6.25. Utjecaj zone $1700 \mathrm{~m}\left(\mathrm{k}_{\mathrm{p}}\right)$ na PTSF za različite slučajeve opterećenja 
$\mathrm{Na}$ osnovu rezultata regresijske analize pojedinih zona (izrazi $\triangle \mathrm{PTSF}$ na grafikonima) definirani su grafikoni utjecaja pojedine zone $k_{p} u$ funkciji analiziranog $V_{d}$ i suprotnog toka $V_{o}$.

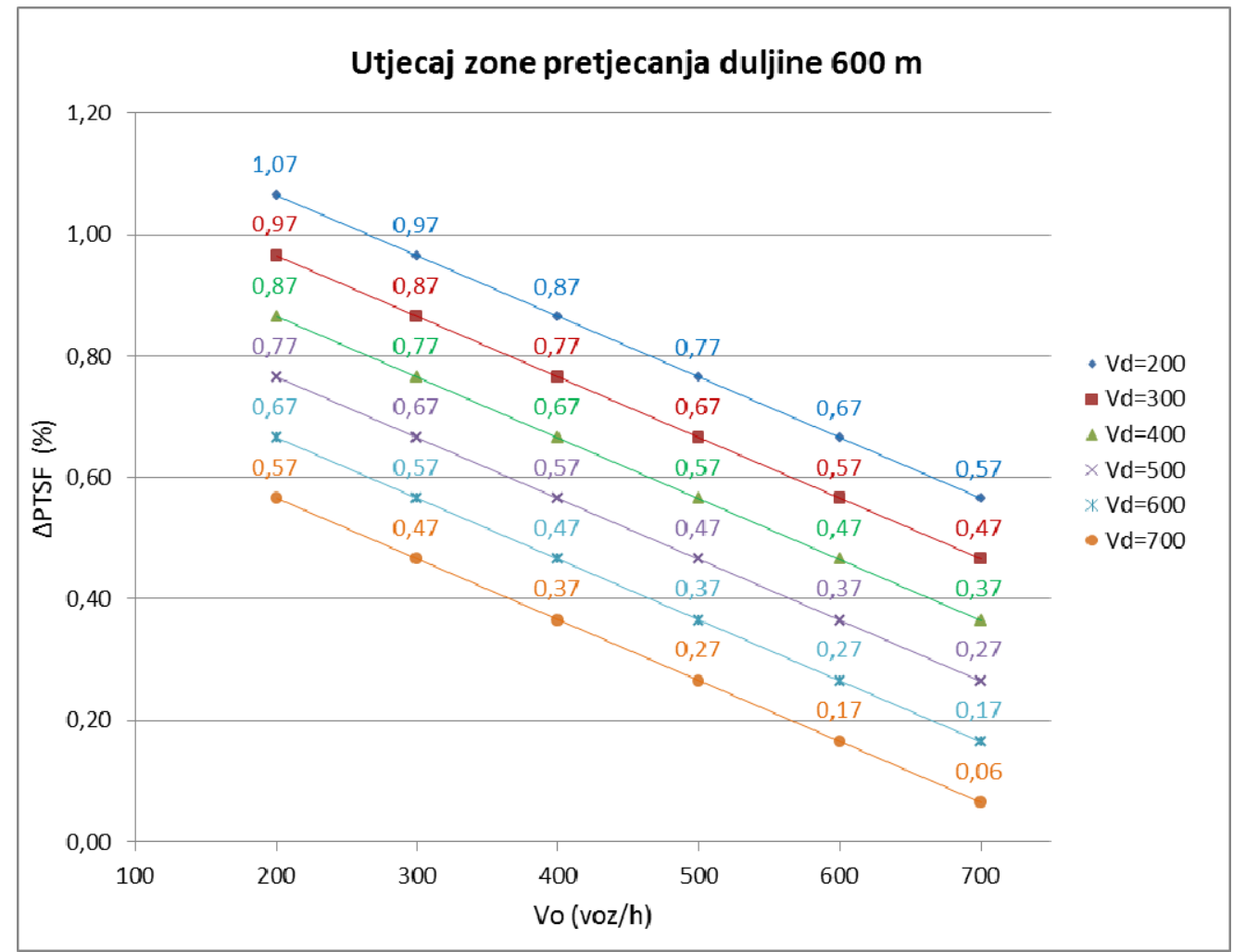

Grafikon 6.26. Utjecaj zona $600 \mathrm{~m}\left(\mathrm{k}_{\mathrm{p}}\right)$ na PTSF dionice

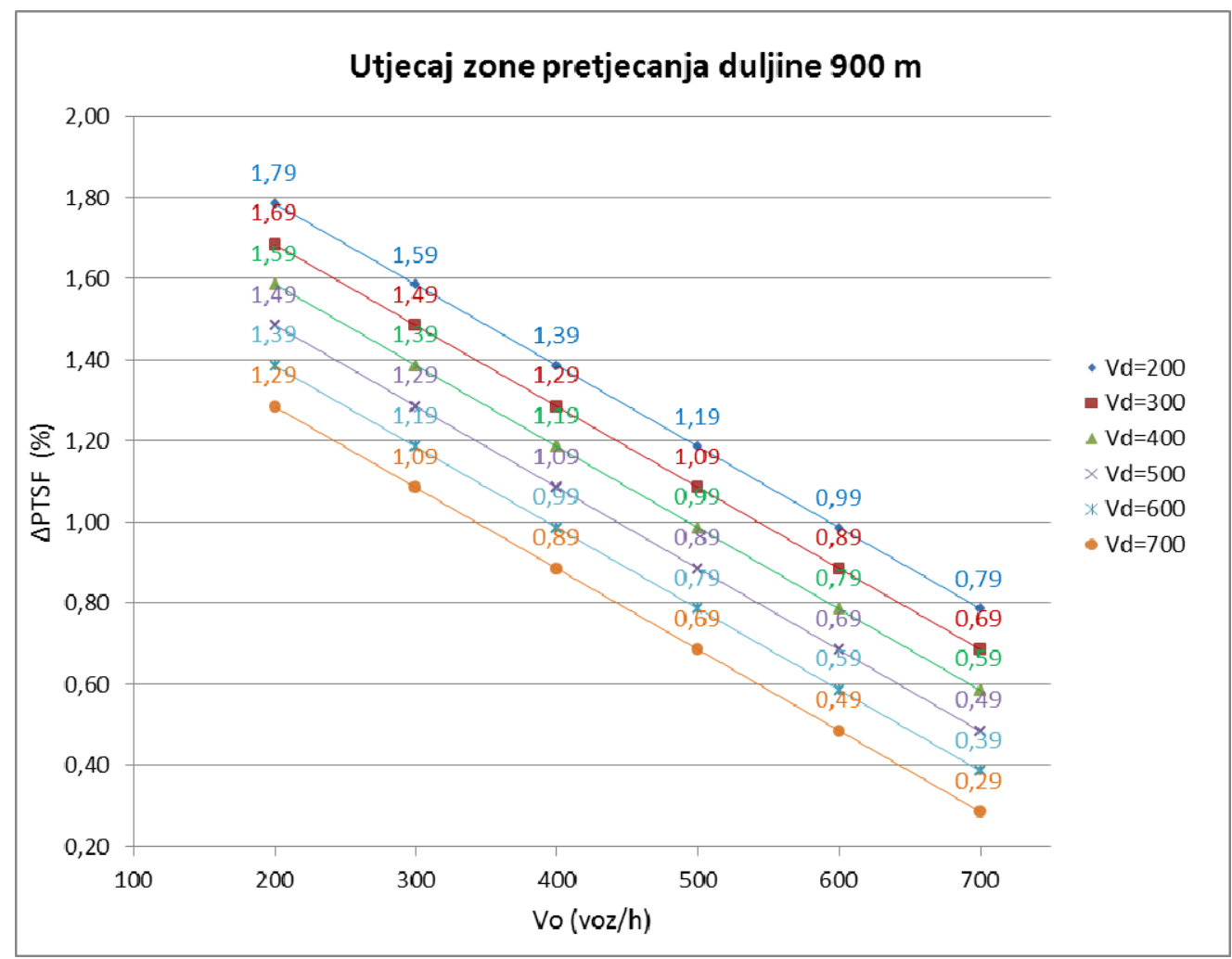

Grafikon 6.27. Utjecaj zona $900 \mathrm{~m}\left(\mathrm{k}_{\mathrm{p}}\right)$ na PTSF dionice 


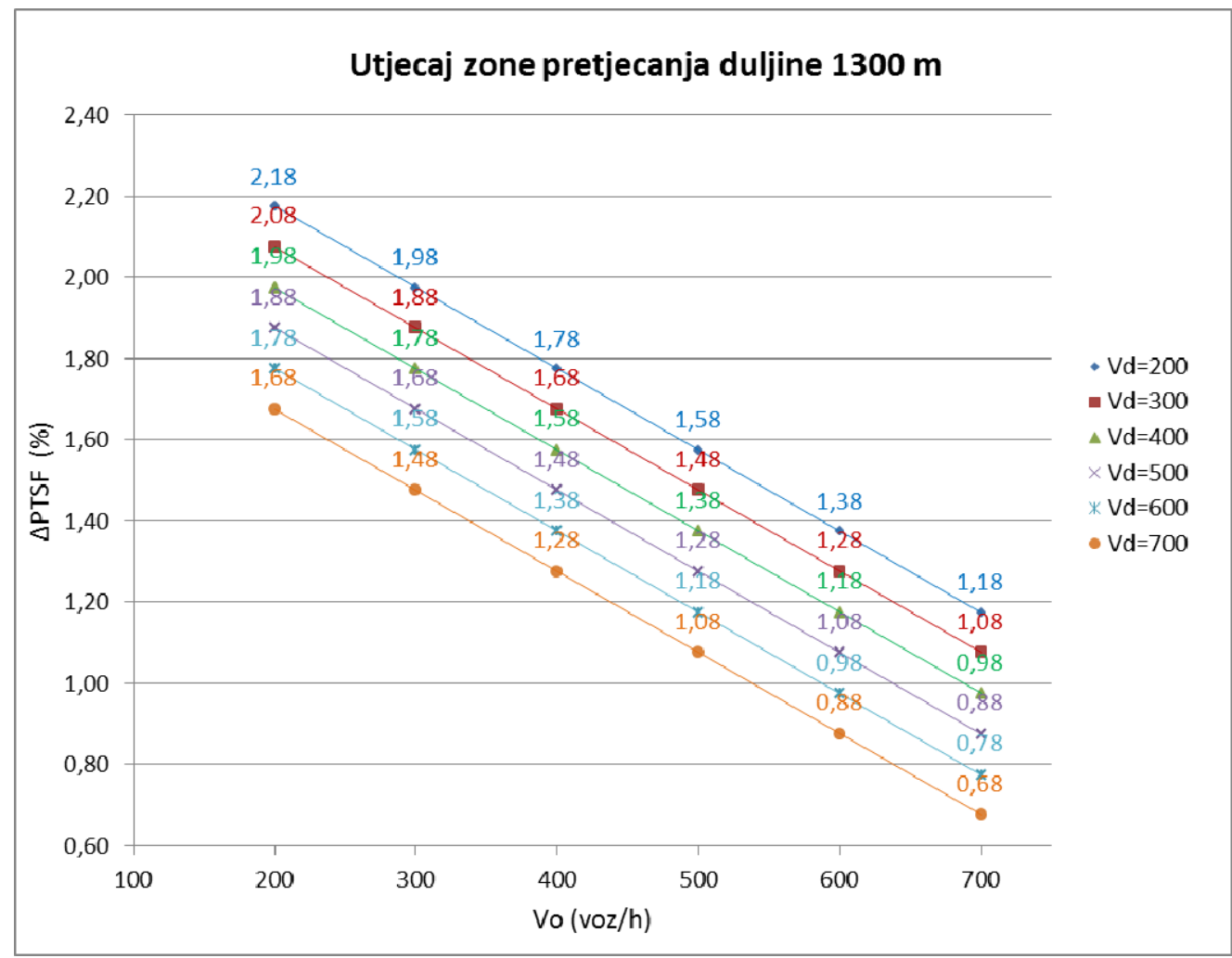

Grafikon 6.28. Utjecaj zona $1300 \mathrm{~m}\left(\mathrm{k}_{\mathrm{p}}\right)$ na PTSF dionice

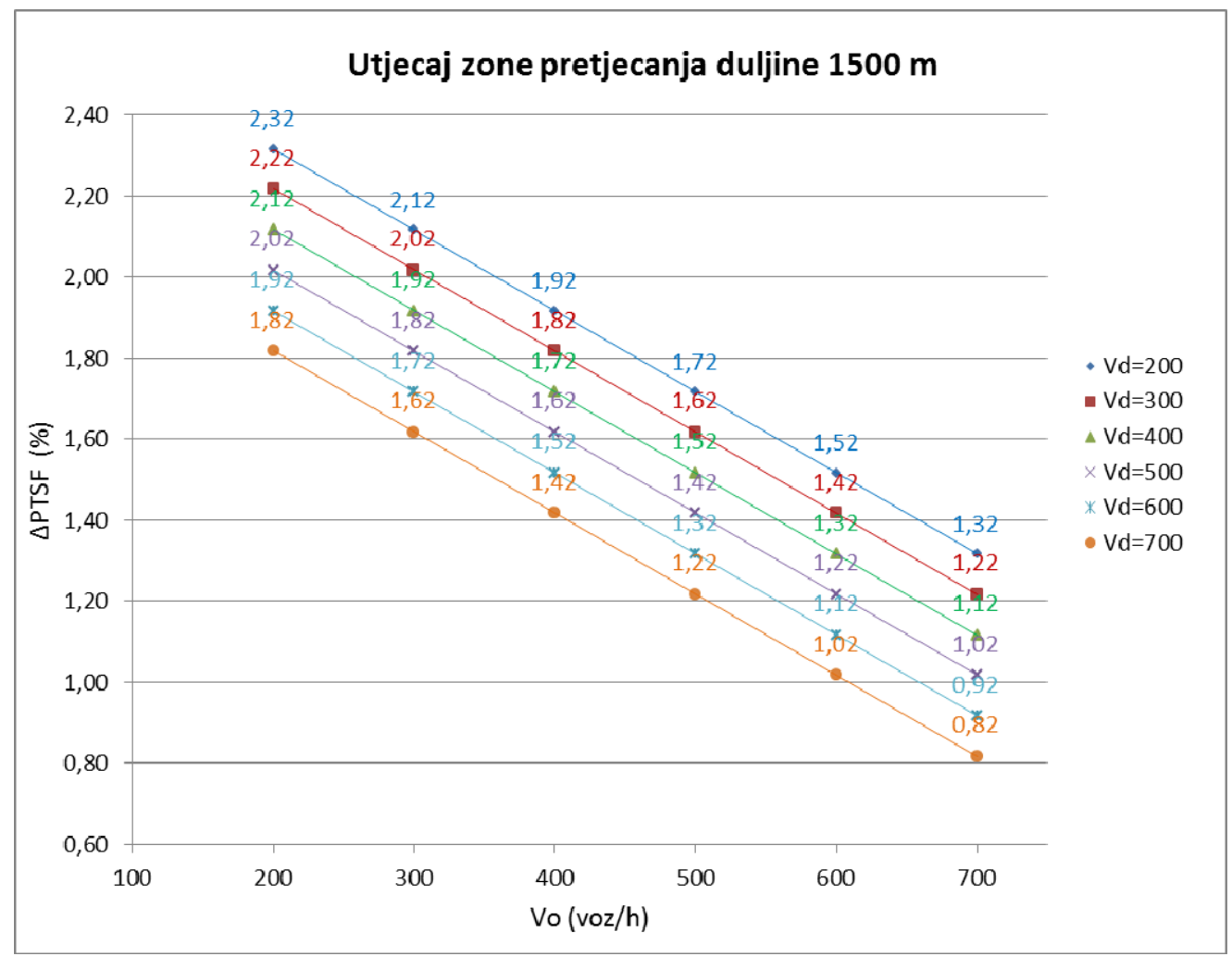

Grafikon 6.29. Utjecaj zona $1500 \mathrm{~m}\left(\mathrm{k}_{\mathrm{p}}\right)$ na PTSF dionice 


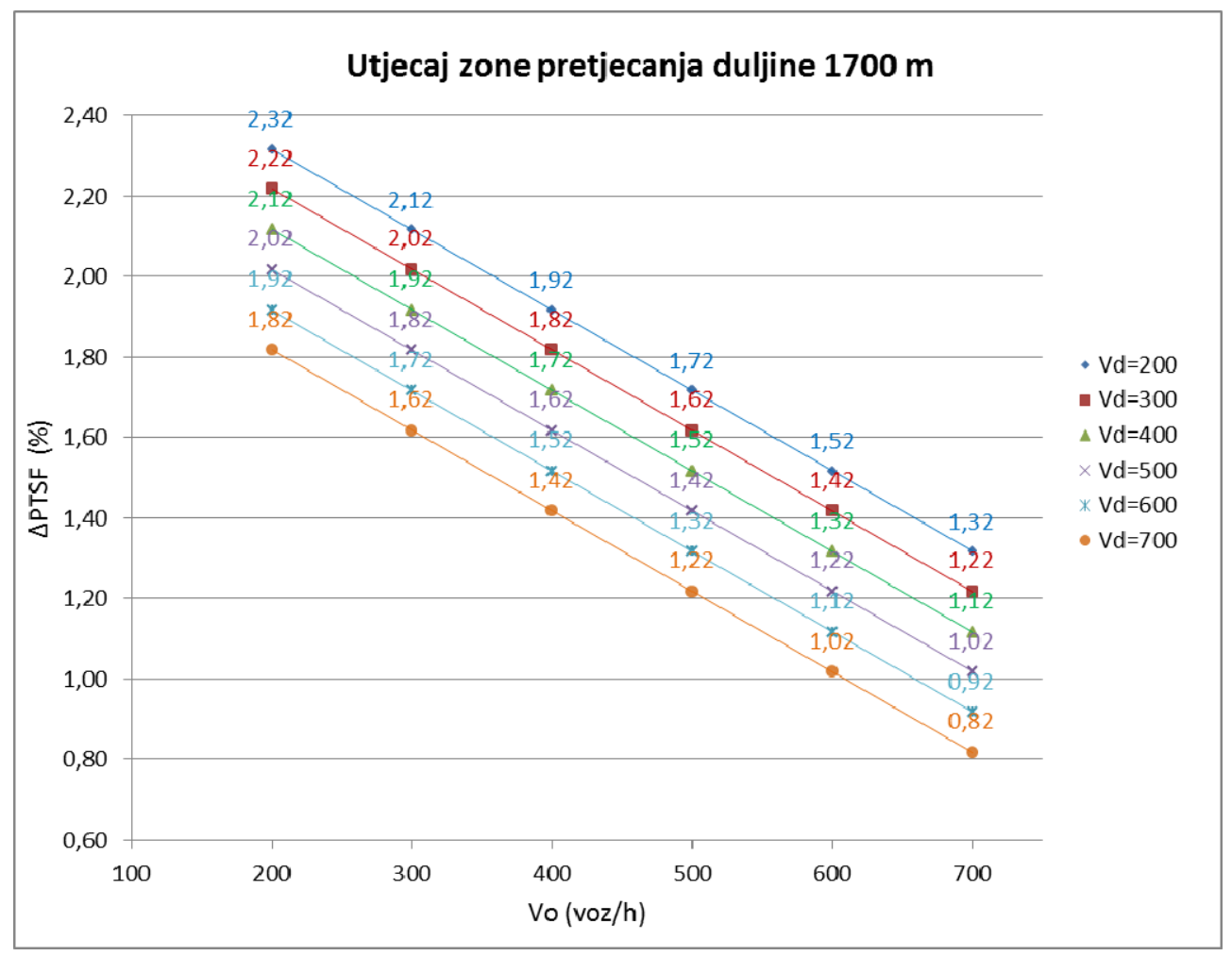

Grafikon 6.30. Utjecaj zona $1700 \mathrm{~m}\left(\mathrm{k}_{\mathrm{p}}\right)$ na PTSF dionice

Na grafikonu 6.31 prikazani su radi usporedbe utjecaji zona pretjecanja na PTSF dionice za distribuciju opterećenja 50/50.

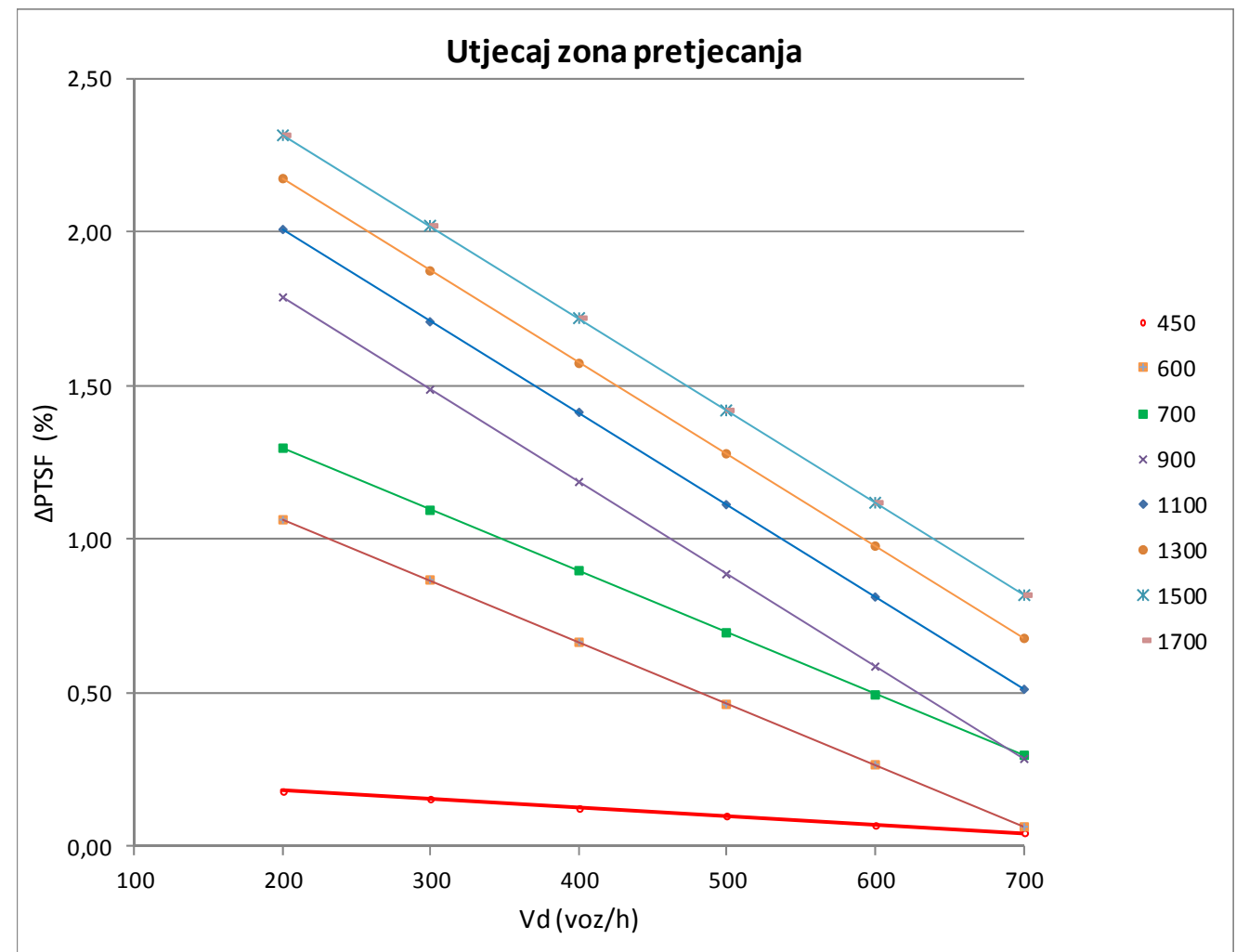

Grafikon 6.31. Utjecaj zona pretjecanja $\mathrm{k}_{\mathrm{p}}$ na PTSF dionice (za distribuciju opterećenja 50/50) 
Iz rezultata se može vidjeti da zone pretjecanja duljine $450 \mathrm{~m}$ imaju zanemariv utjecaj na PTSF dionice. Povećanjem duljine zone pretjecanja povećava se promjena PTSF-a, osobito do duljine zone $900 \mathrm{~m}$. Nakon ove zone utjecaj PTSF-a se povećava, ali ne tako značajno, do zone duljine $1500 \mathrm{~m}$. Nakon toga povećanje utjecaja je zanemarivo pa se utjecaj zona $1500 \mathrm{~m}$ i 1700 m gotovo poklapa (u skladu sa španjolskim istraživanjima [M.2]).

Također se može vidjeti mala nelogičnost promjene PTSF-a između zona duljina 700 m i 900 m, a rezultat su preciznosti modela (radi se o vrlo malim vrijednostima koje su zanemarivog utjecaja na PTSF dionice).

\subsection{Novi model proračuna PTSF-a}

Novi model proračuna PTSF-a dionice definira se kao razlika prosječnog PTSF-a za 100\% NPZ (PTSF $\overline{100 \% N P Z})$ i pojedinačnih utjecaja zona pretjecanja ( $\triangle \mathrm{PTSF})$. Konkretno, za analiziranu dionicu će biti:

$$
P T S F=P T S F \overline{100 \% N P Z}-1 \cdot k_{p 1100}-1 \cdot k_{p 700}-11 \cdot k_{p 450}
$$

U jednadžbi 6.2 koeficijenti $k_{p}$ predstavljaju utjecaj pojedinih duljina zona pretjecanja, a broj uz njih predstavlja broj takvih zona.

Rezultati i razlike novog modela i simulacije terena za smjer Salakovac - Grabovica prikazani su u tablici 6.21 .

Tablica 6.21. Rezultati i razlike novog modela i simulacije terena smjera Salakovac - Grabovica za distribuciju 50/50

\begin{tabular}{|c|c|c|c|c|}
\hline $\mathbf{V}_{\mathbf{d}}$ & $P T S F_{100 \% N P Z}$ & $\begin{array}{c}\text { Simulacija } \\
\text { postojeće } \\
\text { dionice }\end{array}$ & $\begin{array}{c}\text { Novi } \\
\text { model }\end{array}$ & $\begin{array}{c}\text { Razlika } \\
(\%)\end{array}$ \\
\hline 200 & 48.00 & 44.48 & 43.07 & -3.17 \\
\hline 300 & 58.00 & 53.90 & 53.81 & -0.17 \\
\hline 400 & 64.00 & 60.63 & 60.56 & -0.12 \\
\hline 500 & 69.00 & 65.90 & 66.30 & 0.61 \\
\hline 600 & 72.00 & 70.25 & 70.05 & -0.28 \\
\hline 700 & 75.00 & 73.95 & 73.79 & -0.22 \\
\hline
\end{tabular}

Poopćeni izraz je:

$$
P T S F=P T S F \overline{100 \% N P Z}-N_{1100} \cdot k_{p 1100}-N_{700} \cdot k_{p 700}-N_{450} \cdot k_{p 450}
$$

Koeficijenti N predstavljaju broj zona jednakih duljina. U općem obliku jednadžba predloženog modela je: 


$$
P T S F=P T S F \overline{100 \% N P Z}-\sum_{i=1}^{n} N_{i} \cdot k_{p i}
$$

Model je primjenjiv za izvangradske dvotračne ceste koje imaju računsku brzinu 80 km/h.

Kao što je ranije definirano, za $P T S F_{100 \% N P Z}$ se uzimaju preporučene vrijednosti pojedinih opterećenja analiziranog toka (tablica 6.2) kada nije poznata početna vrijednost PTSFa, ili proračunom konkretne vrijednosti za poznati početni PTSF i definirani porast po kilometru (izraz 6.2.). Na ovaj način se dobio jednostavan i, za uporabu, praktičan model proračuna PTSFa dionice.

\subsection{Validacija modela}

Validacija modela provedena je na magistralnoj cesti M17 južno od Mostara prema Čapljini, na dionici Buna - Ševaš Njive. Kraj dionice je nakon 15.5 km u Ševaš Njivama iz razloga jer cesta u nastavku prolazi kroz naseljena područja (slika 6.1).

Dionica ima slične geometrijske karakteristike kao analizirana dionica Salakovac Grabovica:

- duljina $15500 \mathrm{~m}$

- 22 horizontalnih krivina

- minimalni polumjer horizontalne krivine je $\mathrm{R}_{\min }=250 \mathrm{~m}$

- uzdužni nagibi $<3 \%$

- $\quad$ krivinska karakteristika $55.24^{\circ} / \mathrm{km}$

- ukupno 12 zona za pretjecanje, po jedna $1700 \mathrm{~m}, 700 \mathrm{~m}$, dvije zone po $600 \mathrm{~m}$ te 8 zona duljina $400-450 \mathrm{~m}$

- računska brzina od $80 \mathrm{~km} / \mathrm{h}$.

Kao što se može vidjeti predmetna dionica ima vrlo dobre geometrijske karakteristike kao i dionica Salakovac - Grabovica. Početak dionice na Buni nastavlja se na cestu u naselju gdje je brzina ograničena na $60 \mathrm{~km} / \mathrm{h}$, dok je nastavak na kraju dionice (na jugu) kroz naseljena područja i ograničenu brzinu $50 \mathrm{~km} / \mathrm{h}$.

Postavljena su 4 brojila na odabrane presjeke dionice, na početak i kraj dionice, te prije i poslije zone pretjecanja duljine $1700 \mathrm{~m}$. Presjeci imaju stacionaže $0+000,2+800,5+600$ i $15+500$ u smjeru Buna - Ševaš Njive i 0+000, 9+900, 12+700 i 15+500 u smjeru Ševaš Njive Buna. 
Snimanja su trajala 8 dana što je za rezultat dalo oko 450 satnih opterećenja (dobivenih iz 15 minutnih opterećenja) za svaki od presjeka.

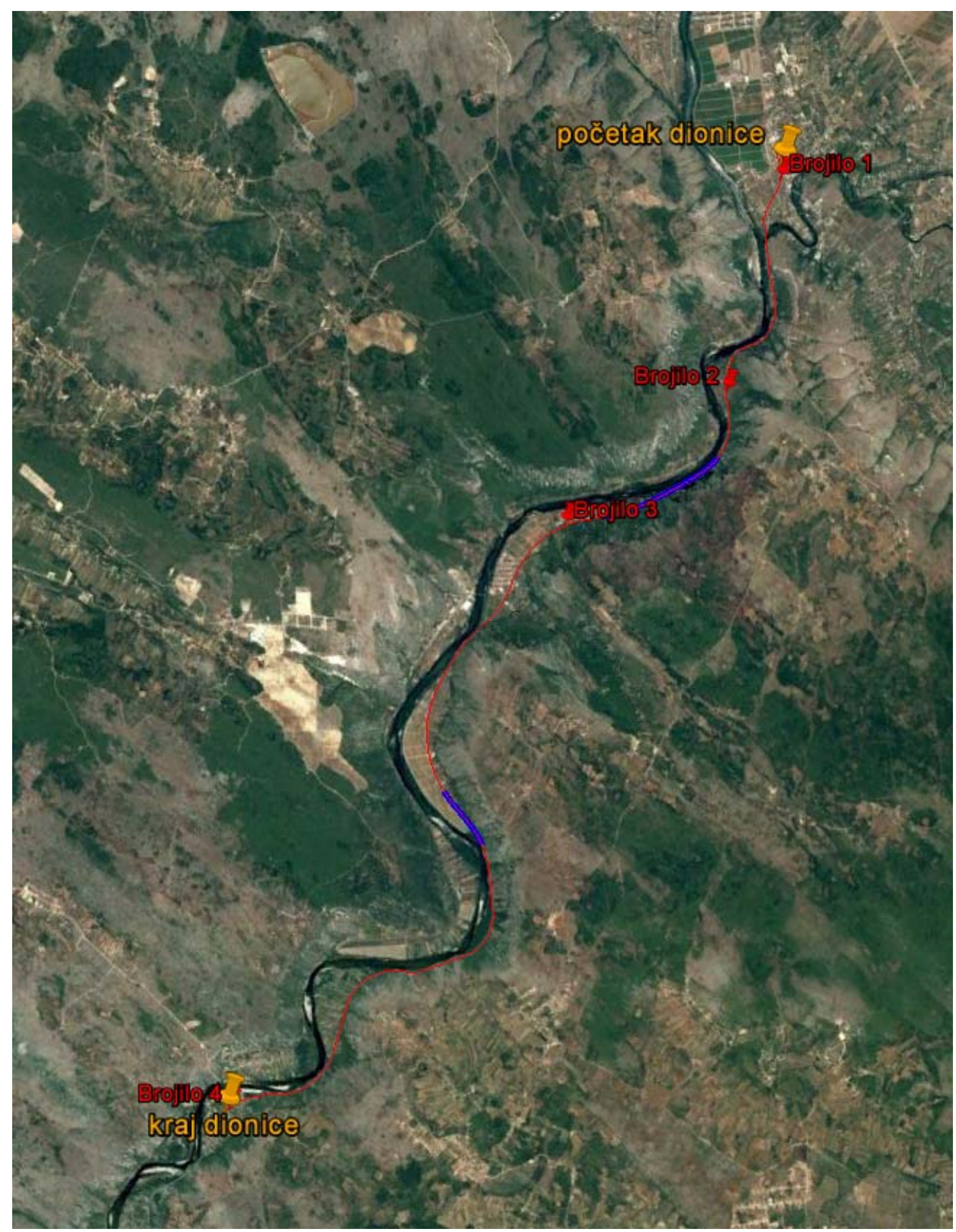

Slika 6.1. Dionica Buna - ك̌evaš Njive (Mostar - Čapljina) za validaciju modela

Za smjer Buna - Ševaš Njive dobiveni rezultati na terenu su nepotpuni zbog problema rada brojila te stoga nisu prezentirani u radu. 
Dobiveni rezultati PTSF-a (smjer Ševaš Njive - Buna) satnih opterećenja na 4 presjeka povezani su regresijski i prikazani su na grafikonu 6.32 .

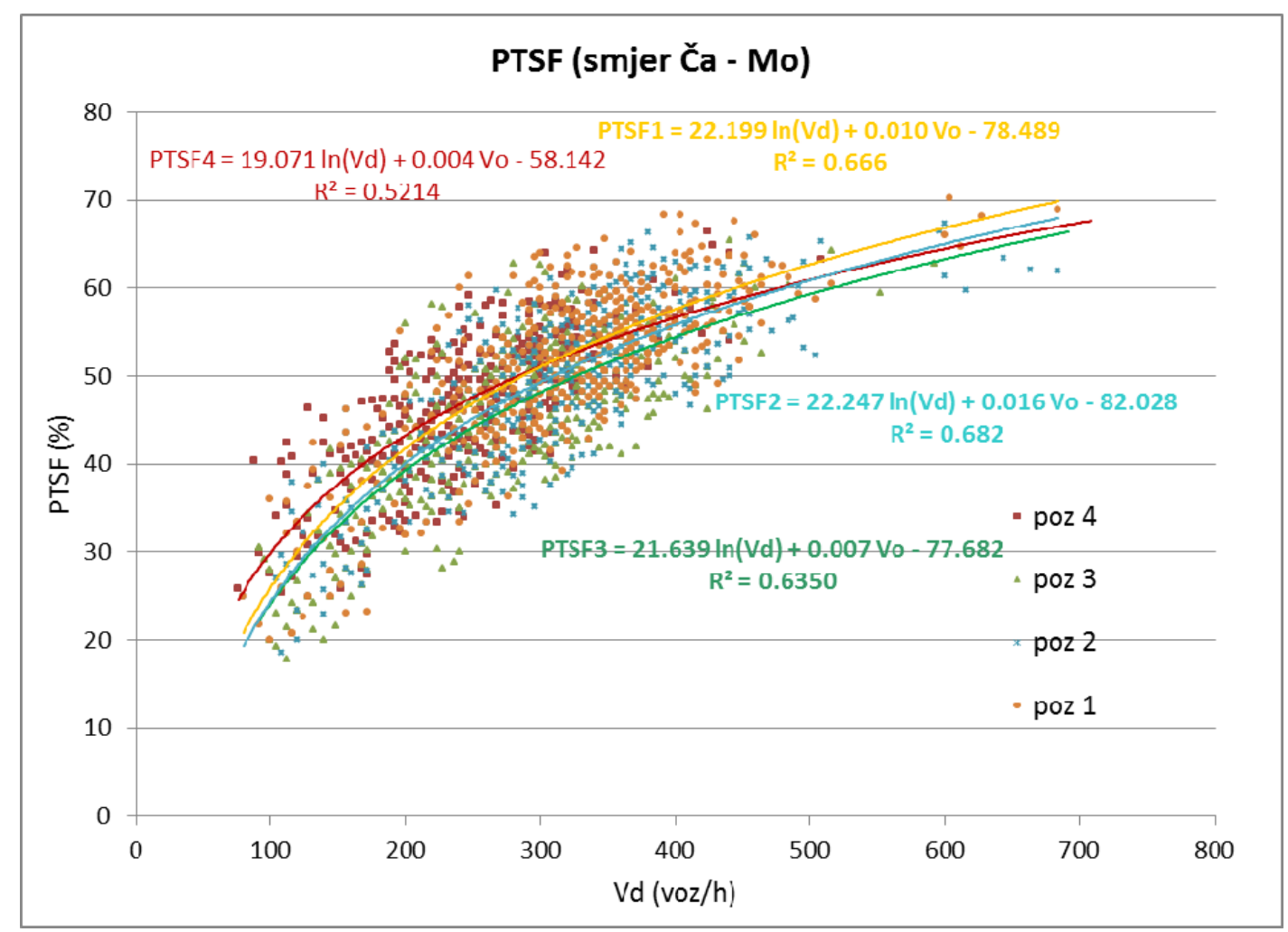

Grafikon 6.32. Rezultati mjernih mjesta za smjer Ševaš Njive - Buna

Model proračuna ove dionice može se dobiti po istom principu kao što je urađeno za dionicu Salakovac - Grabovica. Na temelju 4 presjeka (izrazi za PTSF na grafikonu 6.32) i razmaku između njih dobije se (prema izrazu 4.11 u poglavlju 4) izraz za proračun PTSF-a ove dionice:

$$
P T S F_{\text {dionice }}=21.049 \cdot \ln \left(V_{d}\right)+0.008 \cdot V_{o}-72.777
$$

Ovaj izraz predstavlja rezultat snimljenih podataka na terenu i usporedit će se s novim modelom proračuna.

Novi model proračuna PTSF-a je najprije provjeren za proračun preko usvojene prosječne vrijednosti $P T S F_{100 \% N P Z}$. Dobiveni rezultati ovog modela i usporedba s rezultatima dobivenim na terenu prikazani su u tablici 6.22 . 
Tablica 6.22. Rezultati i razlike novog modela i dobivenih rezultata s terena za smjer Ševaš Njive - Buna (za distribuciju opterećenja 50/50)

\begin{tabular}{|c|c|c|c|c|}
\hline $\mathbf{V}_{\mathbf{d}}=\mathbf{V}_{\mathbf{o}}$ & $\begin{array}{c}\text { Rezultati } \\
\text { PTSF-a } \\
\text { s terena }\end{array}$ & $\begin{array}{c}P T S F_{100 \% N P Z} \\
\text { usvojeni } \\
\text { prosječni }\end{array}$ & $\begin{array}{c}\text { PTSF } \\
\text { prema } \\
\text { novom } \\
\text { modelu }\end{array}$ & $\begin{array}{c}\text { Razlika } \\
\text { model/teren } \\
\mathbf{( \% )}\end{array}$ \\
\hline $\mathbf{2 0 0}$ & 40.35 & 48.00 & 40.81 & $\mathbf{1 . 1 4}$ \\
\hline $\mathbf{3 0 0}$ & 49.68 & 58.00 & 51.93 & $\mathbf{4 . 5 3}$ \\
\hline $\mathbf{4 0 0}$ & 56.54 & 64.00 & 59.05 & $\mathbf{4 . 4 4}$ \\
\hline $\mathbf{5 0 0}$ & 62.03 & 69.00 & 65.17 & $\mathbf{5 . 0 6}$ \\
\hline $\mathbf{6 0 0}$ & 66.67 & 72.00 & 69.28 & $\mathbf{3 . 9 1}$ \\
\hline $\mathbf{7 0 0}$ & 70.72 & 75.00 & 73.40 & $\mathbf{3 . 7 9}$ \\
\hline
\end{tabular}

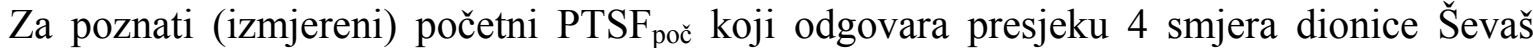
Njive - Buna, te koeficijente nakupljanja $\mathrm{k}_{\text {nak }}$, može se definirati $P T S F \overline{100 \% N P Z}$ za duljinu dionice $15.5 \mathrm{~km}$. rezultati su prikazani u tablici 6.23 .

Tablica 6.23. Rezultati i razlike novog modela i dobivenih rezultata s terena smjera Ševaš Njive - Buna (za distribuciju opterećenja 50/50)

\begin{tabular}{|c|c|c|c|c|c|c|}
\hline$V_{d}=V_{o}$ & $\begin{array}{c}\text { PTSF }_{\text {poč }} \\
\text { presjek } 4\end{array}$ & $\begin{array}{c}\mathbf{k}_{\text {nak. }} \\
\% / \mathbf{k m}\end{array}$ & $\begin{array}{c}P T S F_{100 \% N P Z} \\
\text { za duljinu } \\
\mathbf{1 5 . 3} \mathbf{~ k m}\end{array}$ & $\begin{array}{c}\text { PTSF } \\
\text { prema } \\
\text { novom } \\
\text { modelu }\end{array}$ & $\begin{array}{c}\text { Rezultati } \\
\text { PTSF-a s } \\
\text { terena }\end{array}$ & $\begin{array}{c}\text { Razlika } \\
\text { model/teren } \\
(\%)\end{array}$ \\
\hline 200 & 42.70 & 0.84 & 49.21 & 42.02 & 40.35 & 4.14 \\
\hline 300 & 50.83 & 0.83 & 57.26 & 51.19 & 49.68 & 3.04 \\
\hline 400 & 56.72 & 0.78 & 62.77 & 57.81 & 56.54 & 2.25 \\
\hline 500 & 61.38 & 0.66 & 66.50 & 62.66 & 62.03 & 1.02 \\
\hline 600 & 65.25 & 0.57 & 69.67 & 66.95 & 66.67 & 0.42 \\
\hline 700 & 68.59 & 0.54 & 72.78 & 71.18 & 70.72 & 0.65 \\
\hline
\end{tabular}

Iz rezultata dobivenih u tablicama 6.22 i 6.23 može se vidjeti da je model dao nešto veće, ali vrlo dobre rezultate prema oba načina definiranja $P T S F \overline{100 \% N P Z}$. Proračun $P T S F \overline{100 \% N P Z}$ preko nakupljanja dao je preciznije rezultate što je i logično jer je detaljnije definiran preko početnog PTSF-a i duljine dionice. 


\section{ZAKLJUČCI I SMJERNICE ZA BUDUĆI RAD}

\subsection{Zaključci}

$\mathrm{Na}$ temelju terenskih istraživanja $\mathrm{i}$ analize rezultata, osvrtom na HCM i druge metodologije, mogu se donijeti sljedeći zaključci:

1.HCM i druge metodologije proračunom daju znatno različite rezultate od onih dobivenih na terenu.

2.Utjecaj opterećenja suprotnog toka daje nešto drugačije rezultate nego je to slučaj prema HCM-u. Prema HCM-u PTSF opada povećanjem suprotnog toka, dok se vrijednosti PTSF-a dobivene na terenu povećavaju (vrlo malo, ali ipak povećavaju) za povećanje suprotnog toka.

3. Utjecaj udjela zona bez pretjecanja za raspon 70 - $100 \%$ nije prikladan za naše uvjete.

4. Duljina i broj pojedinih zona pretjecanja nije obuhvaćena proračunom, a pokazale su se vrlo bitnim.

5. Kratke zone pretjecanja imaju zanemariv utjecaj na PTSF dionice.

6. BPTSF nije prikladan kao početni parametar s obzirom da je teško mjerljiv na terenu.

Zbog svega navedenog izrađen je novi model proračuna PTSF-a prilagođen našim prevladavajućim uvjetima. Novi pristup i model uključuju:

1. Uvođenje $P T S F \overline{100 \% N P Z}$ umjesto BPTSF kao početnog za proračun: Time se omogućilo jednostavnije kalibriranje jer je dobar dio dionica u $\mathrm{BiH}$ gotovo bez mogućnosti pretjecanja.

2.Predloženi model omogućuje i preciznije proračune za različite duljine dionice:

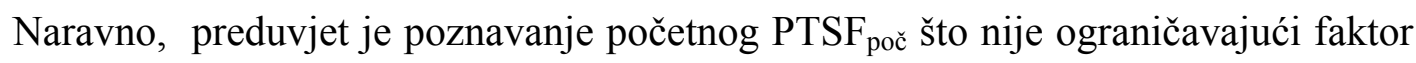
s obzirom na tehniku brojenja prometa.

3. Izravno definiranje utjecaja pojedinih zona pretjecanja na PTSF dionice: Time se preciznije definirao utjecaj pretjecanja, jer ukupni postotak (NPZ) dionice nije dovoljan parametar.

4. Model omogućuje i širu primjenu na ostale kategorije cesta uz dodatna istraživanja.

5. Ovakav „linijski“ pristup promjene PTSF-a na dionici omogućuje bolje sagledavanje razine usluge cijele dionice. 


\subsection{Preporuke za daljnja istraživanja}

Predložena istraživanja predstavljaju novi i drugačiji pristup koji može biti temelj za buduća istraživanja.

1. Potrebno je obuhvatnije istražiti zone pretjecanja, a osobito utjecaj kraćih zona.

2. Predloženi model se odnosi na dionice (većinom magistralne ceste) gdje je $V_{r}=80$ $\mathrm{km} / \mathrm{h}$, te bi model trebalo nadograditi i proširiti kako bi bio primjenjiv za sve ostale kategorije brzina (cesta).

3. Kao jedina „prava“ mjera za unaprijeđenje cestovne mreže nameće se izgradnja dodatnog trećeg traka za spora vozila. Pravilna definicija potrebne duljine i položaja dodatnog traka moguća je jedino „linijskim“ pristupom praćenja PTSF-a na svakom dijelu dionice, što se može osigurati na način kakav je prezentiran u ovom radu. 


\section{LITERATURA}

[A.1] Al-Kaisy, A. and Freedman, Z. Estimating Performance on Two-lane Highways: Case Study Validation of a New Methodology, Transportation Research Record 2173, Transportation Research Board, National Research Council, Washington, DC, 2010, pp. 72-79., 2010.

[A.2] Al-Kaisy, A. and Durbin, C. Estimating Percent Time Spent Following on Two-lane Highways: Field Evaluation of New Methodologies, Transportation Research Board 86th Annual Meeting, January 21-25. Transportation Research Board, Washington, D.C., 2007.

[A.3] Al-Kaisy, A. and Durbin, C. Evaluating New Methodologies for Estimating Performance on Two-lane Highways. Canadian Journal of Civil Engineering. NRC Research Press. 35(8): 777-785., 2008.

[A.4] Al-Kaisy, A. and Karjala, S. Indicators of Performance on Two-Lane Rural Highways: An Empirical Investigation. Transportation Research Record: Journal of the Transportation Research Board, No. 2071, Transportation Research Board of the National Academies, Washington, D. C., 87-97., 2008.

[A.5] Al-Kaisy, A., Jafari, A., Washburn, S., Lutinnen, T. and Dowling, R. Performance Measures on Two-Lane Highways: Survey of Practice. Transportation Research Board Annual Meeting, Washington, D. C., 16-5259, 2016.

[A.6] Al-Kaisy, A., Jafari, A. and Washburn, S. Following Status and Percent Followers on TwoLane Two-Way Highways: Empirical Investigation, Transportation Research Board Annual Meeting, Washington, D. C., 2017.

[A.7] Al-Kaisy, A. and Karjala, S. Car-following interaction and the definition of free-moving vehicles on two-lane rural highways. Journal of Transportation Engineering 2010; 136(10): 925-931. 2010.

[A.8] Al-Kaisy, A. and Durbin, C. Platooning on Two-lane Two-way Highways: an Empirical Investigation. In Journal of Advanced Transportation, Volume 43, Issue 1, pp. 71-88., 2009. 
[B.1] Bessa, J.E.J. and Setti, J.R. Derivation of ATS and PTSF functions for two-lane, rural highways in Brazil. Procedia - Social and Behavioral Sciences, 16: 282-292., 2011.

[B.2] Bessa, J.E.J., Setti, J.R. and Washburn, S. Evaluation of Models to Estimate Percent Time Spent Following on Two-Lane Highways. American Society of Civil Engineers 2017.

[B.3] Brilon, W. and Weiser, F. Two-lane Rural Highways: The German Experience. Transportation Research Record, Transportation Research Board. National Research Council, Washington, DC. 1988: p. 38-47., 2006.

[C.1] Catbagan, J. L. and Nakamura, H. Evaluation of Performance Measures for Two-lane Expressways in Japan. Transportation Research Record, Transportation Research Board National Research Council, Washington, DC. 1988: 111-118., 2006.

[D.1] Dixon, M. P., Sarepali, S. S. K. and Young, K. A. Field Evaluation of Highway Capacity Manual 2000 Analysis Procedures for Two-Lane Highways. Transportation Research Record: Transportation Research Board. National Research Council, Washington, D.C. 1802(2002): 125-132., 2002.

[F.1] FGSV: Handbuch fuer die Bemessung von Strassen (German Highway Capacity Manual) HBS 2001, FGSV, Cologne, edition 2005.

[F.2] FGSV: Handbuch fuer die Bemessung von Strassen (German Highway Capacity Manual) HBS 2015, FGSV, Cologne, edition 2015.

[G.1] Ghosh, I., Chandra, S., Boora, A. Operational Performance Measures for Two-Lane Roads: An Assessment of Methodological Alternatives, Social and Behavioral Sciences 104440 448., 2013.

[G.2] Greenshields, B. D., H. P. George, N. S. Guerin, M. R. Palmer, and R. T. Underwood. Quality and Theory of Traffic Flow. Bureau of Highway Traffic, Yale University, New Haven, Conn., 1961. 
[H.1] Harwood, D. W. et al. Two-lane Road Analysis Methodology in the Highway Capacity Manual. In NCHRP Project 20-7(160) Washington, D.C., 2003.

[H.2] Hashim I.H., Abdel-Wahed, T.A. Evaluation of performance measures for rural two-lane roads in Egypt. Alexandria, Engineering Journal; 50(3): 245-255., 2011.

[L.1] Luttinen, R. T. Capacity and Level of Service on Finnish Two-Lane Highways. Finnra reports 18/2001. Finnish Road Administration, Helsinki, 2001.

[L.2] Luttinen, R. T. Percent Time-Spent-Following as Performance Measure for Two-Lane Highways. Transportation Research Record. Transportation Research Board, National Research Council. Washington, D.C. 1776: 52-59, 2001.

[L.3] Laval, J. A. A macroscopic theory of two-lane rural roads. Transportation Research Part B: Methodol., 40(10), 937-944., 2006.

[L.4] Luttinen, R.T. Statistical Analysis of Vehicle Time Headways. Helsinki University of Technology. Transportation Engineering, Publication. 87: 193., 1996.

[L.5] Luttinen, T., Dixon, M. and Washburn, S. Two-Lane Highway Analysis in HCM 2000, Draft White Paper, Retrieved from the internet 05/05/2016 from: https://people.sunyit.edu/lhmi/ahb40/meetings/2005-07/White.pdf, 2003.

[L.6] Leutzbach, W. and Wiedemann, R. Development and application of traffic simulation models at the Karslruhe Institute for Traffic. Traffic Engineering and Control 27 (5), pp. 270-278. 1986.

[M.1] Moreno, A. T., Lorca, C., Sayed, T. and Garcia, A. "Field evaluation of traffic performance measures for two-lane highways in Spain." Paper 14-0847, 93rd Transportation Research Board Annual Meeting, Transportation Research Board, Washington, DC., 2014.

[M.2] Moreno, A.T., Llorca, C., Washburn, S., Bessa, J.E., Hale, D.K. and Garcia, A. Modification of the Highway Capacity Manual two-lane highway analysis procedure for Spanish conditions. Journal of Advanced Transportation; 50:1650-1665., 2016.

[M.3] Moreno, A.T., Llorca, C., García, A., Pérez-Zuriaga, A.M. Operational effectiveness of passing zones depending on their length and traffic volume. Transportation Research Record: Journal of the Transportation Research Board; 2395: 57-65., 2013. 
[M.4] Moreno, A. T., Lorca, C., Washburn, S., Bessa, J. E. J. and Garcia, A. Effect of Average Passing Zone Length on Spanish Two-Lane Highways Traffic Performance, Transportation Research Board 95th Annual Meeting,. Transportation Research Board, Washington, D.C., 2016.

[O.1] Oregon Department of Transportation. Modeling Performance Indicators on Two-Lane Rural Highways: The Oregon Experience, 2010. Retrieved from the internet 05/05/2017 from:www.oregon.gov/ODOT/Planning/Documents/ModelingPerformanceIndicators_TwoLaneRuralHighways.pdf

[P.1] Pravilnik o osnovnim uvjetima koje javne ceste, njihovi elementi i objekti na njima moraju ispunjavati s aspekta sigurnosti, "Službeni glasnik BiH", broj 6/06, Sarajevo, 2007.

[P.2] Polus, A. and Cohen, M. Theoretical and Empirical Relationships for the Quality of Flow and for a New Level of Service on Two-Lane Highways. Journal of Transportation Engineering, ASCE. 135(6): 380-385., 2009.

[P.3] Polus, A. and Cohen, M. Estimating Percent-time-spent-following on Two-lane Rural Highways. Transportation Research Part C: Emerging Technologies. 19(6): 1319-1325., 2011 .

[P.4] Pursula, M. Approximation of percentage time delay with local measurements. Transportation Research Record, 1484: 58-65., 1995.

[P.5] Penmetsa, P., Ghosh, I., and Chandra, S. Evaluation of Performance Measures for TwoLane Intercity Highways under Mixed Traffic Conditions. ASCE Journal of Transportation Engineering, Volume 141, Issue 10, 2015.

[P.6] PTV AG, VISSIM user's manual, version 8.0, Karlsruhe, Germany, 2015.

[R.1] Rozenshtein, S., Polus, A. and Cohen, M. Models for Estimating Drivers Following on Two-Lane Rural Highways. Transportation Research Record. Journal of the Transportation Research Board. 2286(-1): 68-75., 2012.

[R.2] Rozenshtein, S., Polus, A. and Cohen, M. Models for Estimation of Drivers' Impatience on Two-Lane Rural Highways. Transportation Research Board Annual Meeting, Washington, D. C., 13-0451, 2012. 
[R.3] Romana, G.M. and Pérez, I. Measures of Effectiveness for Level-of-Service Assessment of Two-Lane Roads: An Alternative Proposal Using a Threshold Speed. Transportation Research Record. 1988(1): 56-62., 2006.

[S.1] Saha, P., Sarkar, A. and Pal1, M. Evaluation of Performance Measures of Two-Lane Highways under Heterogeneous Traffic. Pertanika J. Sci. \& Technol. 23 (2): 223 - 239., 2015.

[S.2] Sangeetha, M., Gaurav, K.J., Anjaneyulu, M.V.L.R., Harikrishna, M. Platooning on Two Lane Rural Highways. 12th Transportation Planning and Implementation Methodologies for Developing Countries. TPMDC 2016, Mumbai, India, 2016.

[Š.1] Šraml, M. i Jovanović, G. Mikrosimulacije u prometu (radni udžbenik s primjenom VISSIM-a), Maribor, 2014.

[T.1] Transportation Research Board. Highway Capacity Manual. Fourth Edition, TRB, National Research Council, Washington, D. C., 2000.

[T.2] Transportation Research Board. Highway Capacity Manual. Fifth Edition, TRB, National Research Council, Washington, D. C., 2010.

[T.3] Transportation Research Board. Highway Capacity Manual. Sixth Edition, TRB, National Research Council, Washington, D. C., 2016.

[T.4] Transportation Research Board. Highway Capacity Manual. Third Edition, TRB, National Research Council, Washington, D. C., 1985.

[V.1] Van As, S.C. and Van Niekerk, A. The Operational Analysis of Two-lane Rural Highways. 23rd Annual Southern African Transport Conference. Pretoria, South Africa, 2004.

[W.1] http://www.tratech.biz/metrocount/urun/9

[W.2] Www.metrocount.com/downloads/mc5600\%20rsu\%20operator\%20guide.pdf

[W.3] Wiedemann, R. Modelling of RTI-Elements on multi-lane roads. Advanced Telematics in Road Transport edited by the Commission of the European Community, DG XIII, Brussels. 1991. 
[W.4] Wiedemann, R. and Reiter, U. Microscopic Traffic Simulation: The Simulation System Mission. Department of Authomatics and Informatics.Torino. 1992.

[Y.1] Yu, Q. and Washburn S. Operational Performance Assessment for Two-Lane Highway Facilities. Journal of Transportation Engineering, ASCE, Vol. 135, No. 4, pp. 197-205., 2009. 